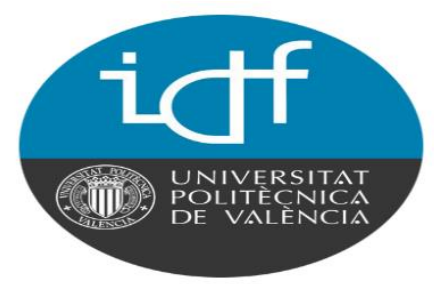

UNIVERSITAT

POLITĖCNICA

DE VALĖNCIA
UNIVERSITAT POLITÈCNICA de VALÈNCIA UNIVERSITAT IBN TOFAIL de KENITRA
Centre Universitaire d'Analyse, d'Expertise de Transfert de Technologie et d'Incubateur

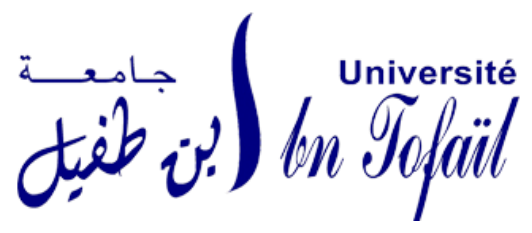

\title{
Study and Characterization of
}

\section{Hybrid Perovskites and Copper-Indium-Gallium selenide thin films \\ for Tandem Solar Cells}

\author{
Author \\ Amal Bouich \\ A dissertation Submitted for the degree of Doctor of Philosophy. \\ Supervised by: Prof Dr. Bernabé Marí Soucase \\ Prof Dr. Mohammed Ebn Touhami \\ Departamento de Física Aplicada-IDF \\ Universitat Politécnica de Valencia (Spain)
}

SEPT 2020 


\section{Table of Contents}

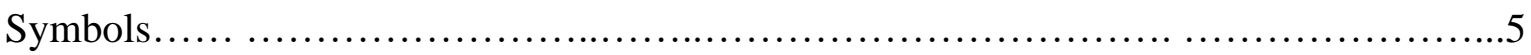

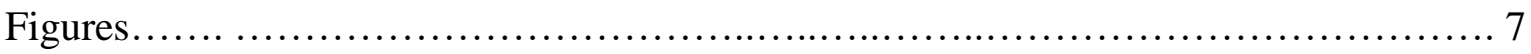

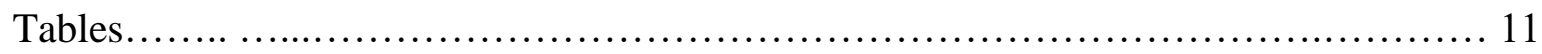

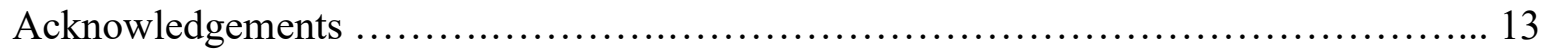

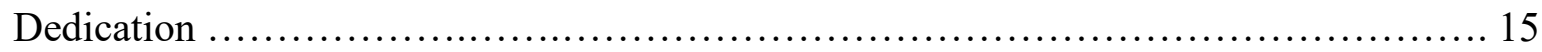

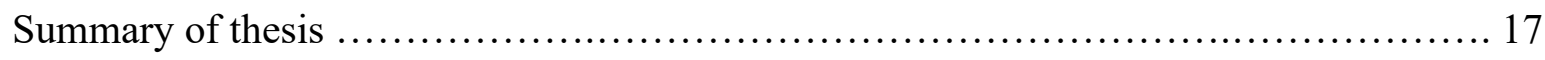

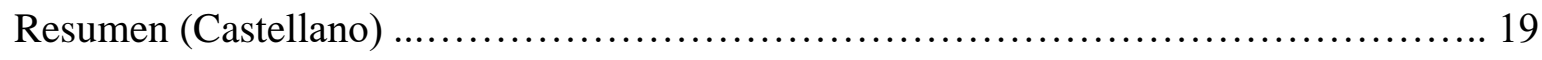

\section{Chapter I:}

\section{Overview of Solar Cells Applications}

\section{Contents}

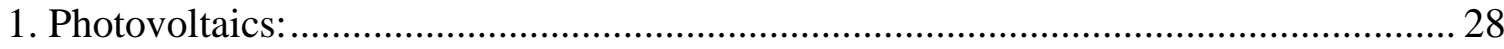

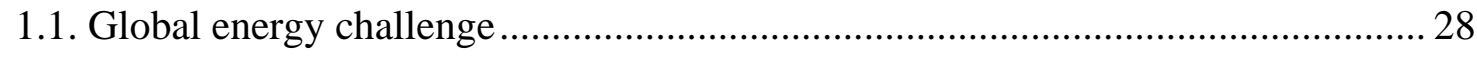

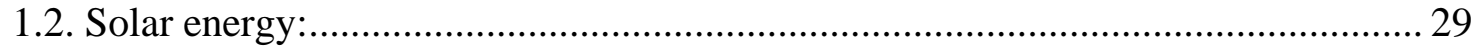

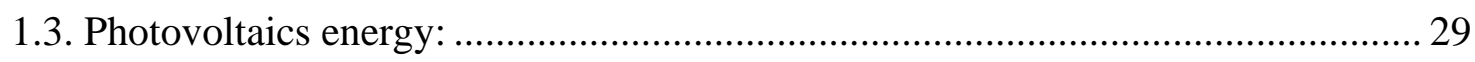

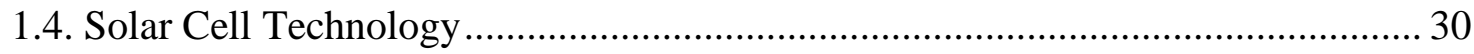

1.4.1. First generation: crystalline Si solar cells ......................................................... 30

1.4.2. Second PV Generation: thin film solar cells...................................................... 31

1.4.3. 3rd Generation PV: perovskite solar cells ...................................................... 31

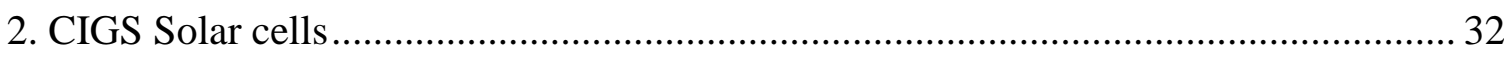

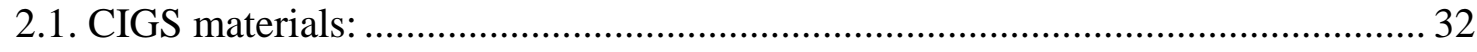

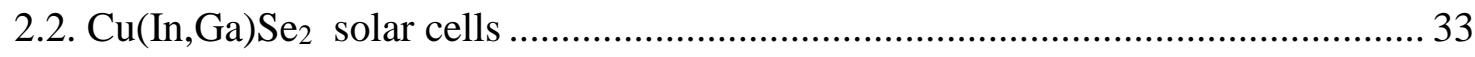

2.3. Energy band diagram of $\mathrm{Cu}(\mathrm{In}, \mathrm{Ga}) \mathrm{Se}_{2}$ solar cells. .............................................. 33

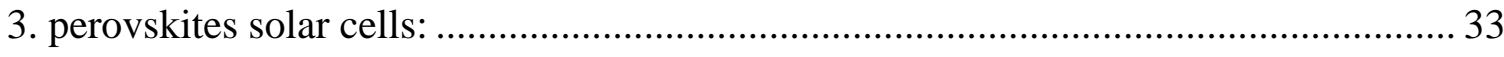

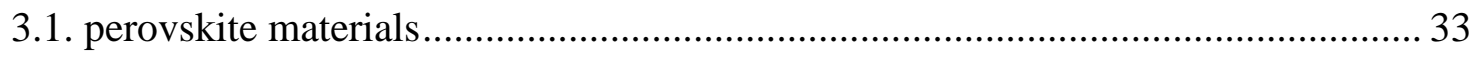

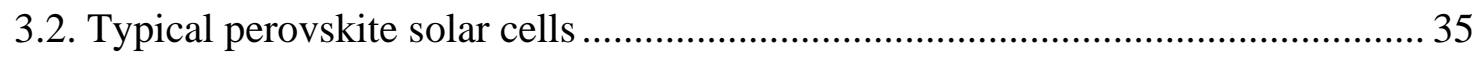

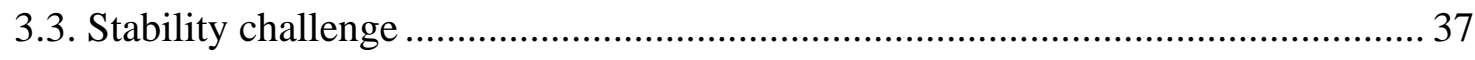




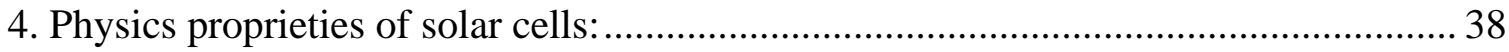

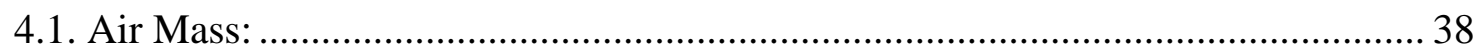

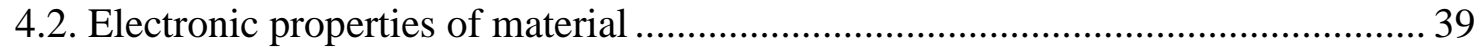

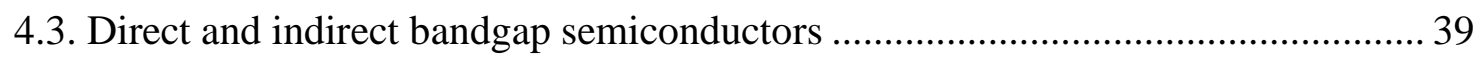

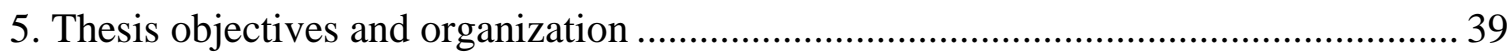




\section{Chapter II:}

\section{Experimental procedures and \\ Characterization techniques of CIGS and Perovskite Solar cells}

\section{Contents}

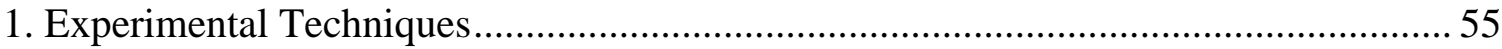

1.1. Electrochemical Deposition of the absorber CIGS thin films ................................55

1.2. Chemical Bath Deposition (CBD) for buffer layer CdS deposition:........................56

1.3. Elaboration of $\mathrm{ABX}_{3}$ perovskite thin films by Spin coating .................................57

1.4. Elaboration of CIGS thin films by spray pyrolysis: .............................................. 58

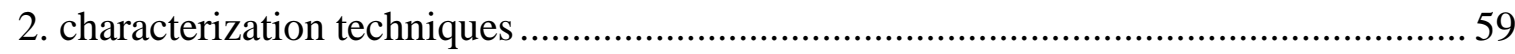

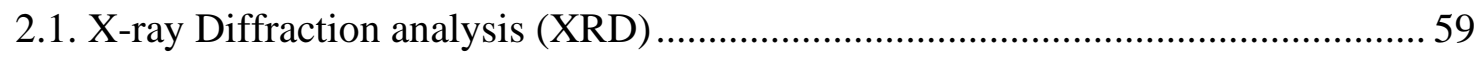

2.2. Field emission Scanning Electron Microscopy (FESEM) ……………………...... 61

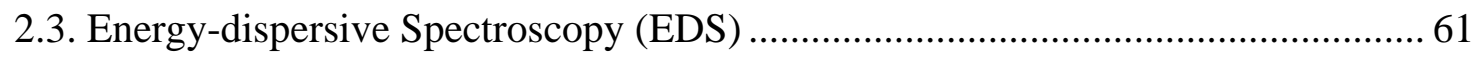

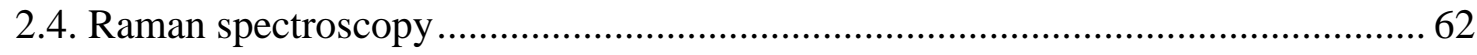

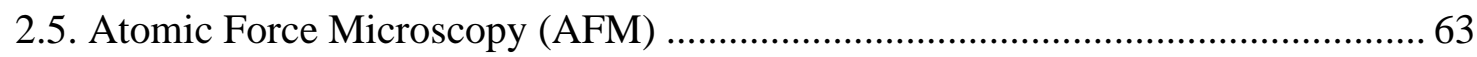

2.6. Transmission electron microscopy (TEM) analysis ................................................ 64

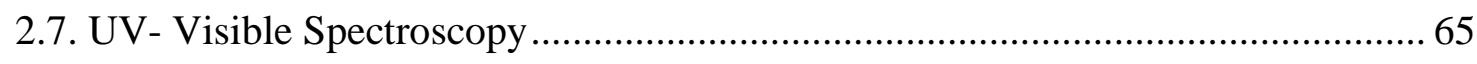

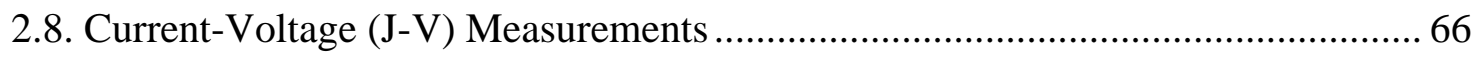




\section{Chapter III:}

\section{Copper-indium-Gallium-disulfide (CIGS) thin films grown by electrochemical deposition for solar cells}

\section{Contents}

1. Investigation of CIGS and CIS grown by one-step electrodeposition technique ......... 72

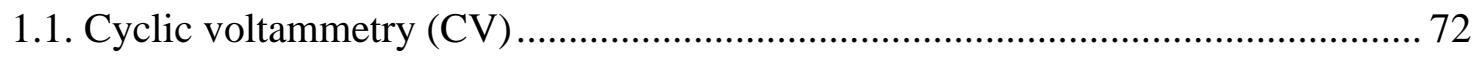

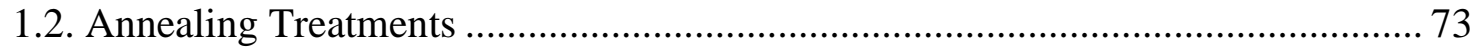

2. Deposit CuInGaS 2 thin film on different backs contacts ............................................. 73

2.1. $\mathrm{CuInGaS}_{2}$ thin film grown by one step electrodeposition: ...................................... 73

2.2. structural and morphology proprieties $\mathrm{CuInGaS}_{2}$ grown by one step electrodeposition

2.2.1. Structural measurements:.......................................................................... 74

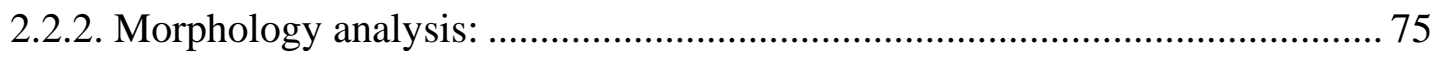

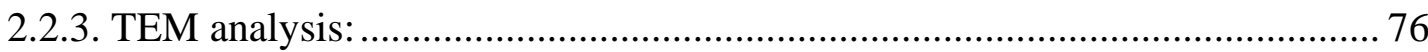

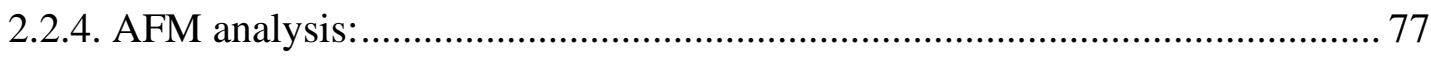

2.3. Optical proprieties $\mathrm{CuInGaS}_{2}$ grown by one step electrodeposition ...................... 78

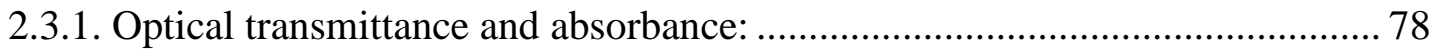

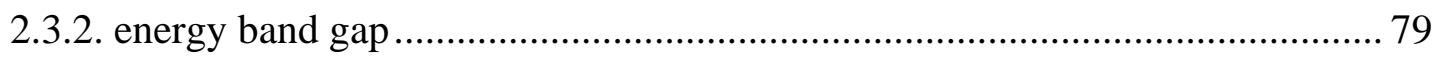

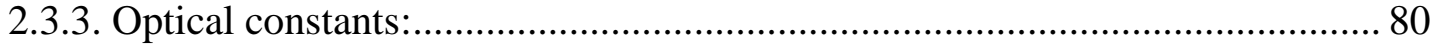

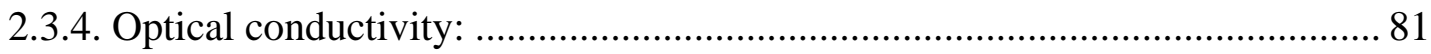




\section{Chapter IV}

\section{Copper-indium-Gallium disulfide (CIGS) thin films grown by Spray pyrolysis for solar cells.}

\section{Contents}

1. Investigation of CIGS and CIS grown by Spray pyrolysis 87

2. Investigation of structural and morphological properties of CIGS grown by Spray pyrolysis

2.1. structural proprieties of CIS and CIGS 87

2.2. Morphology proprieties of CIS and CIGS .88

3. Investigation of optical properties of polycrystalline CIGS grown by Spray pyrolysis technique. 89

3.1. Absorbance, transmittance and gap energy of CIGS grown by Spray pyrolysis technique.

3.2. Optical constants of CIGS grown by Spray pyrolysis technique. 91

4. Suitable annealing time of Copper-indium Gallium disulfide (CIGS) thin films grown by Spray pyrolysis .93

4.1. Copper-indium Gallium disulfide (CIGS) thin films grown by Spray pyrolysis 93

4.2. structural and morphology properties of Copper-indium Gallium disulfide (CIGS) thin films grown by Spray pyrolysis 94

4.2.1. XRD analysis of (CIGS) thin films grown by Spray pyrolysis ............................. 94

4.2.2. SEM analysis of (CIGS) thin films grown by Spray pyrolysis ............................. 96

4.2.3. TEM analysis of (CIGS) thin films grown by Spray pyrolysis .............................97

4.2.4. AFM analysis of (CIGS) thin films grown by Spray pyrolysis ............................ 98

4.3. Optical and electrical proprieties of (CIGS) thin films grown by Spray pyrolysis:.. 100

4.3.1. Absorbance, transmittance and gap energy: ....................................................... 100

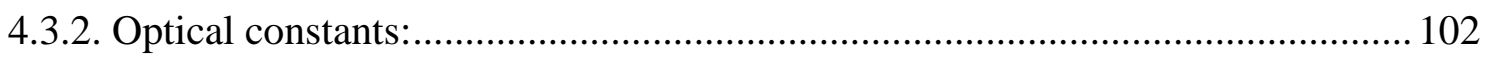




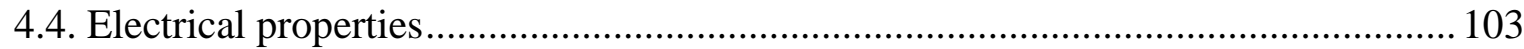

5. Simulation performance of CIGS grown by Spray pyrolysis technique........................... 104

5.1. Simulation of the performance of CIGS grown by spray pyrolysis technique ......... 106

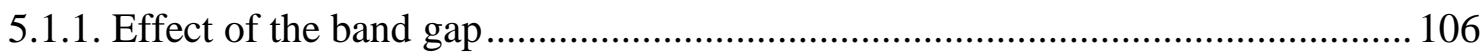

5.1.2. Effects of operating temperature on the performance of CIGS solar cells ......... 108

5.1.3. Effect of shallow acceptor density on the performance of the CIGS cell .......... 109

\section{Chapter V}

\section{Manufacture of CdZnS/CdS/CIGS/Mo solar cells performance.}

\section{Contents}

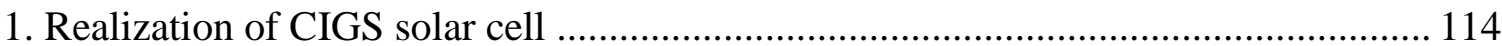

2. Structural and morphology of CdS buffer layer and CIGS absorber layer ................ 115

3. Optical proprieties of CdS buffer layer and CIGS absorber layer: .............................. 118

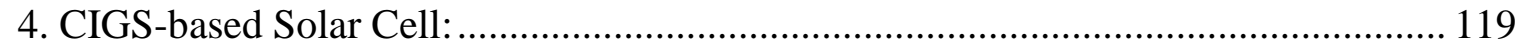




\section{Chapter VI}

\section{Synthesis and characterization of Methylammonium Lead Iodide $\left(\mathrm{MAPbI}_{3}\right)$ perovskite}

\section{Contents}

1. The Study of $\mathrm{MAPbI}_{3}$ Perovskite Thin Films.

124

1.1. Film Preparation of $\mathrm{MAPbI}_{3}$ with different amount of antisolvent perovskite films. 124

1.2. Structural and morphological analysis of $\mathrm{MAPbI}_{3}$ Perovskite Thin Films 126

1.3. Optical properties of $\mathrm{APbX}_{3}(\mathrm{~A}=\mathrm{MA}, \mathrm{FA}, \mathrm{Cs} ; \mathrm{X}=\mathrm{Br}$, I) perovskite films.

2. Degradation study of $\mathrm{MAPbI}_{3}$

3. Methylammonium lead triiodide $\mathrm{MAPb}_{3}$ doping by Tetrabutylammonium (TBA) Perovskites Thin films.

3.1. Film Preparation of $\mathrm{MAPbI}_{3}$ doped Tetrabutylammonium perovskite films 136

3.2. Structural and morphological analysis of $\mathrm{MAPbI}_{3}$ doped Perovskite Thin Films 136

3.3. Optical properties of $\mathrm{MAPbI}_{3}$ doped TBA perovskite films.

4. Degradation study of $\mathrm{MAPbI}_{3}$ doped TBA:. 143

5. Methylammonium lead triiodide $\mathrm{MAPbI}_{3}$ doping by $\mathrm{Rb} \mathrm{Li}$ Cs Perovskites Thin films. 146 


\section{Chapter VII}

\section{Synthesis and characterization of Formamidinium lead triiodide $\mathrm{FAPbI}_{3}$ perovskite.}

1. Film Preparation of $\mathrm{FAPbI}_{3}$ doped Guanidinium perovskite films................................ 141

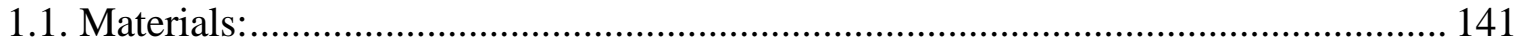

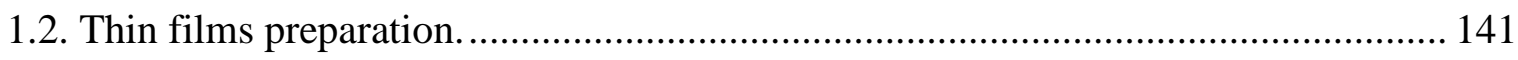

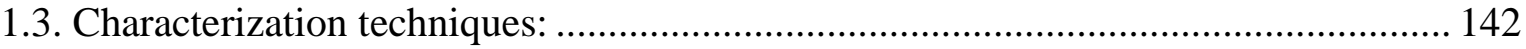

1.4. Structural and morphological analysis of $\mathrm{FAPbI}_{3}$ doped GA Perovskite Thin Films 142

1.5. Optical analysis of $\mathrm{FAPbI}_{3}$ doped GA Perovskite Thin Films.................................... 146

2. Degradation mechanism of $\mathrm{FAPbI}_{3}$ and GA doped $\mathrm{FAPbI}_{3}$ Perovskite Thin Films.......... 148 


\section{Chapter VIII \\ Work Outlook: tandem perovskite/CIGS}

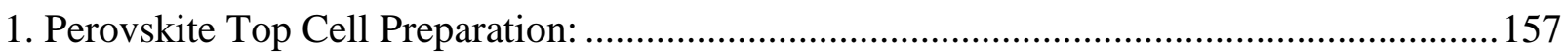

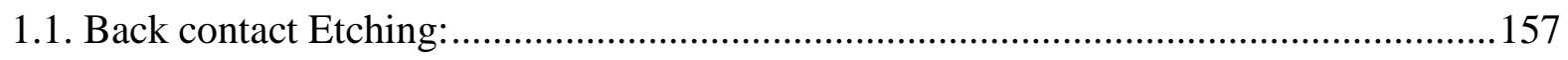

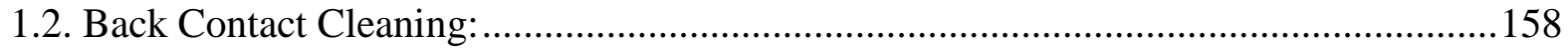

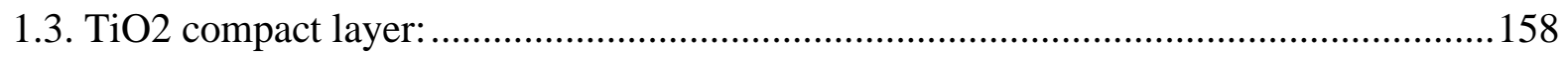

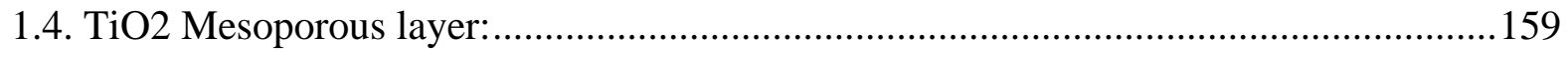

1.5. MAI Powder Synthesis:.............................................................................................159

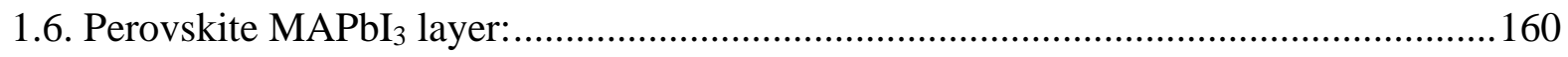

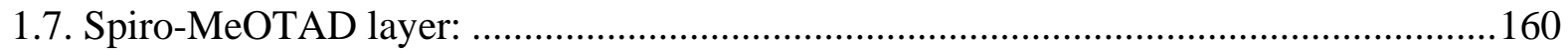

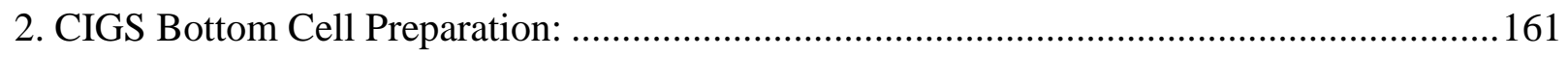

3. Perovskite/CIGS multijunction: ......................................................................................161

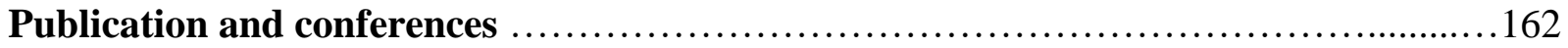




\section{List of abbreviations and symbols}

\section{Symbols}

A

AFM

AM 1.5

$\mathrm{ABX}_{3}$

${ }^{\mathrm{o}} \mathrm{C}$

$\mathrm{CdS}$

CIS

CIGS

$\mathrm{Cu}$

d

EDS

EG

$\mathrm{eV}$

FF

$\mathrm{Ga}$

$\mathrm{h}$

hkl

$\mathrm{I}_{\mathrm{m}}$

In

i: $\mathrm{ZnO}$

$\mathrm{J}_{\text {sc }}$

Mo

nm

P-type

$\mathrm{R}_{\mathrm{s}}$

$\mathrm{R}_{\mathrm{p}}$

S

SEM abbreviations

Absorbance

Atomic Force Microscopy

Air Mass 1.5

where A represents the organic cation, $\mathrm{B}$ denotes lead $(\mathrm{Pb})$, tin $(\mathrm{Sn})$ or germanium $(\mathrm{Ge})$, and $\mathrm{X}$ is halide $(\mathrm{X}=\mathrm{I}, \mathrm{Br}, \mathrm{Cl})$.

Degree Celsius

Cadmium sulfide

Copper indium diselenide

Copper indium gallium diselenide

Copper

lattice spacing in crystal

Energy Dispersive Spectroscopy

Energy band gap

electron volt

Fill Factor in efficiency calculations

Gallium

hour

Miller indices in lattice

Maximum current of a cell

indium

intrinsic zinc oxide

Short circuit current

molybdenum

Nanometer $\left(10^{-9}\right.$ meter $)$

positive type material

Series resistance

Shunt resistance

Sulfur

Scanning Electron Microscopy 
$\mathrm{T}$

$\mu \mathrm{m}$

UV-Vis

V

VB

Voc

XRD
Temperature

micro meter $\left(10^{-6}\right.$ meter $)$

Ultraviolet - Visible

Voltage

Valence Band

Open circuit voltage

X-ray diffraction 


\section{List of figures}

Figure 1.1 Global warming and climate change............................................28

Figure 1.2 Photovoltaic energy power.......................................................29

Figure 1.3 Shows the progress of the best research-solar cell efficiencies since beginning of photovoltaic energy to nowadays for the different generations......................................29

Figure 1.4 Typical CIGS Devices...............................................................30

Figure 1.5 Band diagram of CIGS / CdS /ZnO..................................................33

Figure 1.6 Crystal structure of an organic-inorganic metal halide perovskite........................34

Figure 1.7. Shows different perovskite networks structure: a three-dimensional (3D) perovskite-a two-dimensional (2D) perovskite. - a one-dimensional (1D) perovskite lattice.......................35

Figure 1.8 Shows typical perovskite device been used as carrier transport layers like: the zinc oxide $\mathrm{ZnO}, \mathrm{PCBM}$ as the electron transport layer (ETL) and as the hole transport layer (HTL) spiro-

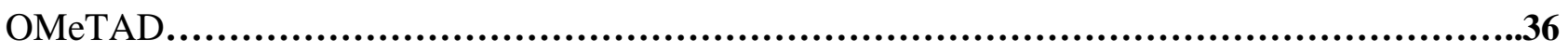

Figure 1.9 Cubic (a) and tetragonal (b) structure of the $\mathrm{CH}_{3} \mathrm{NH}_{2} \mathrm{PbX}_{3}$ perovskite ................... 37

Figure 1.10 Energy bands for conductors, semiconductor, and insulator............................38

Figure 1.11 Shows excited electrons from the valence band to conduction band in semiconductors

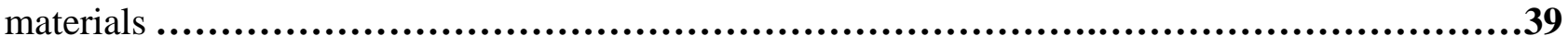

Figure 1.12 Energy band diagram for direct and indirect semiconductors...........................39

Figure 2.1 Schematic illustration of the electrochemical cells.....................................48

Figure 2.2 Procedure of chemical bath deposition technique........................................ 49

Figure 2.3 Schematic representation of spin coating technique................................ 50

Figure 2.4 Representation of Spray pyrolysis technique.................................... 50 


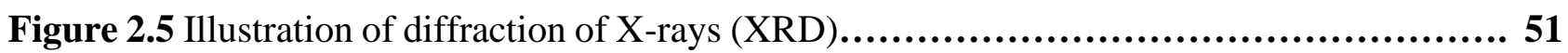

Figure 2.6 Image of scanning electron microscopy (FESEM)...................................... 52

Figure 2.7 Schema representation of Raman spectroscopy $\ldots \ldots \ldots \ldots \ldots \ldots \ldots \ldots \ldots \ldots \ldots \ldots \ldots \ldots \ldots \ldots . .54$

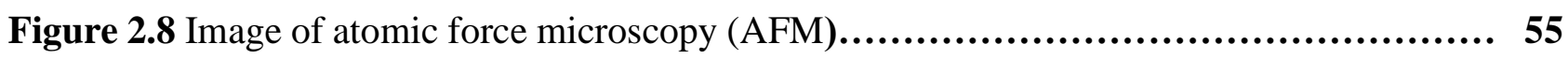

Figure 2.9 Image of transmittance electron microscopy (TEM) ...............................55

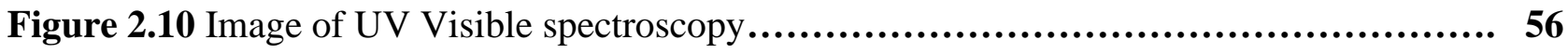

Figure 2.11 J-V curves for a solar cell in the dark and for the same solar cell under illumination

Figure 3.1 Cyclic Voltammograms of a Mo-coated electrode in three precursor electrolytes: blank solution (Black line), (Blue line) and (Green line) ….......................................63

Figure 3.2 Schematic illustration of a typical temperature profile for the post annealing treatment................................................................................63 Figure 3.3 procedure of CIGS thin film deposited in different back contact with Electrodeposition...................................................................... 64

Figure.3.4 XRD analysis of CIGS thin films at different back contact: (a) ITO (b) FTO and (c) Mo

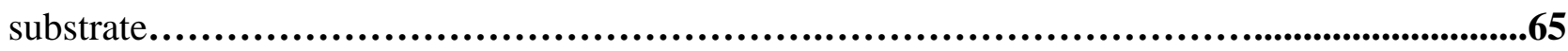

Figure 3.5 SEM images of deposited CIGS with (a) ITO (b) FTO and (c) Mo substrate........... 65 Figure 3.6 TEM images with different lattice fringe spacing (a) ITO, (b) FTO, (c) Mo and (d) Cross section of Mo................................................................................66

Figure 3.7 3D AFM images of (a) ITO-CIGS (b) FTO-CIGS (c) Mo-CIGS....................... 67 Figure 3.8: a) Optical Transmittance of the CIGS thin films with different back contact b) Optical absorbance of the CIGS films deposited by different back contact................................ 68

Figure 3.9 Gap energy of the CIGS thin films obtained by different back contact..................... 68

Figure 3.10: a) Extinction coefficient. b) Refractive index c) Real part dielectric constant d) Imaginary part dielectric constant of CIGS films by different back contact..................... 70

Figure 3.11. Optical conductivity of the CIGS with different back contact............................. 71 
Figure 4.1. X-ray diffraction patterns of the prepared CIS and CIGS films.

Figure 4.2. (a) SEM image of the CIS and (b) CIGS thin film................................ 77

Figure 4.3. a) Optical absorbance b) Optical transmittance spectra of the CIS/CIGS thin films obtained by spray pyrolysis............................................................... 78

Figure 4.4. Band gap energy of the CIS/CIGS thin films obtained by spray pyrolysis............. 78

Figure 4.5.a) Extinction coefficient. b) Refractive index c) Imaginary part of dielectric constant d) Real part of dielectric constant of the CIS/CIGS thin films obtained by spray pyrolysis................... 80

Figure 4.6 Preparation of CIGS thin films Sprayed........................................ 84

Figure.4.7. XRD results for sprayed CIGS with different annealing time...................... 85

Figure. 4.8. SEM images with different annealing time (a) CIGS1 for 5min, (b) CIGS2 for $10 \mathrm{~min}$, (c) CIGS3 for 20 min and (d) Cross Section for CIGS 20 min.................................85

Figure.4.9. TEM images (a) CIGS1 for $5 \mathrm{~min}$, (b) CIGS2 for $10 \mathrm{~min}$ and (c) CIGS3 for $20 \mathrm{~min} . . .86$ Figure. 4.10 2D and 3D AFM images of CIGS thin films (a) CIGS1 5 min, (b) CIGS2 10 min and

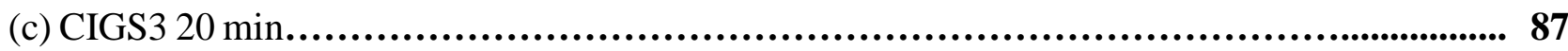

Figure. 4.11. Optical absorbance of the CIGS thin films obtained by spray with annealing ..... 88

Figure. 4.12. Optical transmittance of the CIGS thin films................................ 89

Figure.4.13. structure of the $\mathrm{Cu}-\mathrm{In}-\mathrm{Ga}-\mathrm{S}$, Se (CIGS) solar cell and Performance of CIGS solar cells.......................................................................................... 93

Figure 4.14. The output data of the solar cell (short-circuit current density Jsc, open-circuit voltage Voc, fill factor FF and efficiency EFF) depending on gap energy of the CIGS player....................................................................................... 94

Figure 4.15. The output data of the solar cell (short-circuit current density Jsc, open-circuit voltage Voc, fill factor FF and efficiency EFF) depending on the thickness of the CIGS player...................................................................................... 95 
Figure 4.16. The output data of the solar cell (short-circuit current density Jsc, open-circuit voltage Voc, fill factor FF and efficiency EFF) depending on temperature of the CIGS player... 96

Figure 4.17 The output data of the solar cell (short-circuit current density Jsc, open-circuit voltage Voc, fill factor FF and efficiency EFF) depending on NA of the CIGS player....................................................................................... 97

Figure 5.1 XRD patterns of electrodeposited CIGS............................................. 102

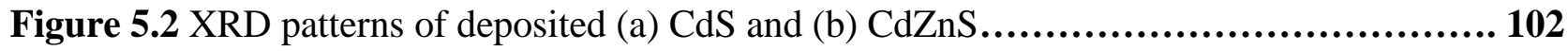

Figure 5.3. SEM images of the thin film CIGS elaborated (a) as-deposited and (b) after annealing. Figure 5.4. SEM images of the films synthesized (a) $\mathrm{Cd}(\mathrm{Zn} 0 \%) \mathrm{S}$ and (b) $\mathrm{Cd}(\mathrm{Zn} \mathrm{5 \% )} \mathrm{S......} 103$ Figure 5.5. AFM (2D) images (2D) of surface morphologies (a) CIGS (b) CdS and

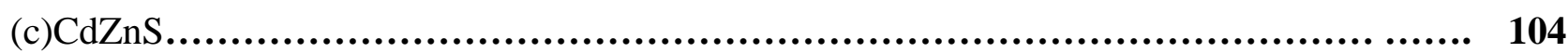

Figure 5.6. Optical Absorption and band gap of CIGS annealed...............................105

Figure 5.7. Optical Absorption and band gap of $\mathrm{CdS}$ and $\mathrm{CdZnS}$ annealed...........................106

Figure 5.8 (a) A typical device SLG/Mo/CIGS/CdS/CdZnS/Au structure configuration and (b) J-V characteristic curve dark and under illumination......................................... 107

Figure 6.1 glovebox machine for elaboration of perovskite thin films........................... 111

Figure 6.2 Different steps for cleaning the FTO substrate..................................... 111

Figure 6.3 Schema illustrates deposition procedure of perovskite thin film..................... 112

Figure 6.4. (a) the obtained XRD patterns with different amounts of antisolvent. (b) The Full width at half maximum $(\mathrm{FWHM})$ for the $(110,220)$ peaks......................................... 113

Figure 6.5. $\mathrm{SEM}$ images of $\mathrm{MaPbI}_{3}$ with different amounts of Antisolvent diethyl ether (a $1 \mathrm{ml}, \mathrm{b}$ $1.5 \mathrm{ml}, \mathrm{c} 2.5 \mathrm{ml}, \mathrm{d} 3 \mathrm{ml})$ and (e) Mapping of halide perovskite................................... 114

Figure 6.6. A schematic representation of two step antisolvent additions....................... 115

Figure 6.7. a, b) SEM images rapid and slow thermal annealing for $60 \mathrm{~min}$ and $100 \mathrm{~min}$ respectively,

c) HRTEM images and d) SEAD of the interface............................................... 116 
Figure 6.8. AFM images of perovskite multiple-cation halide perovskite films $\mathrm{MaPbI}_{3}$ upon addition of different amounts of Antisolvent diethyl ether.

Figure 6.9 a) PL perovskite thin films $\mathrm{MaPbI}_{3}$ upon addition of different amounts of Antisolvent diethyl ether b) UV-vis absorption and c) Optical bandgap of $\mathrm{MaPbI}_{3}$.

Figure 6.10. Degradation mechanism of $\mathrm{MAPbI}_{3}$ in air at $60 \%$ humidity under dark conditions. 119

Figure 6.11. Degradation study of $\mathrm{MAPbI}_{3}$ at ET-2.5 ml (a) Fresh sample SEM image (b)aged sample after 4 weeks and (c) XRD pattern fresh and aged sample after 4 weeks.

Figure.6.12 $\mathrm{XRD}$ pattern of spin coated $\mathrm{MAPbI}_{3}$ films with different amounts of TBA, b) $\mathrm{MAPbI}_{3}$ photographs c) FWHM of peaks (011) and (022), c) Raman spectra of MaPbI3 and 5\% TBA.

Figure.6.13 Shift of (110) and (220) XRD peaks of $\mathrm{MAPbI}_{2}$ perovskite after doping with different amount. 125

Figure.6.14 a) EdS Mapping of $\mathrm{MAPbI}_{2}$ with showing the map distribution of $\mathrm{Pb}$, I elements. b) Top-view SEM images of the $\mathrm{MAPbI}_{3}$ film with different amounts of TBA 126

Figure.6.15 HRTEM Images of $\mathrm{MAPbI}_{3}$ films. The interplanar spacing of $0.76 \mathrm{~nm}$ and 1.31 corresponding of the (220) and (110) planes of 3D perovskites were observed............................................................................................

Figure.6.16 Top-view AFM images 2D and 3D of the $\mathrm{MAPbI}_{3}$ film with different amounts of TBA. 127

Figure.6.17 a) PL spectra of TBA doped and undoped $\mathrm{MAPbI}_{3}$ thin film b) normalized PL spectra of TBA doped and undoped $\mathrm{MAPbI}_{3}$ thin film. 128

Figure.6.18 Top-view SEM images fresh, aged $\mathrm{MAPbI}_{3}$ and 10\% TBA films kept in Argon and in a humid air. 
Figure.6.19 $\mathrm{XRD}$ fresh, aged $\mathrm{MAPbI}_{3}$ and $5 \%$ TBA films kept in Argon and in a humid air.

Figure.6.20 Absorbance spectra of doped $\mathrm{MA}_{X} \mathrm{TBA}_{(1-\mathrm{X})} \mathrm{PbI}_{3}$

Figure 6.22 a) XRD pattern of spin coated MAPbI3 films b) XRD pattern of spin coated $\mathrm{MAPbI}_{3}$ films with different amounts of $\mathrm{Rb}$ c) XRD pattern of spin coated $\mathrm{MAPbI}_{3}$ films with different amounts of CS c) XRD pattern of spin coated MAPbI3 films with different amounts of Li..... 131

Figure 6.23 SEM Image of spin coated MAPbI3 film b) XRD pattern of spin coated MAPbI3 films with $5 \% \mathrm{Rb} \mathrm{c)} \mathrm{XRD} \mathrm{pattern} \mathrm{of} \mathrm{spin} \mathrm{coated} \mathrm{MAPbI3} \mathrm{films} \mathrm{with} \mathrm{different} \mathrm{amounts} \mathrm{of} \mathrm{CS} \mathrm{c)} \mathrm{XRD}$ pattern of spin coated MAPbI3 films with different amounts of Li.............................132 Figure 7.1. (a) XRD patterns of perovskite films $\mathrm{FA}_{1-\mathrm{x}} \mathrm{GA}_{\mathrm{x}} \mathrm{PbI}_{3}$ (b) $\mathrm{FWHM}$ of $\alpha-\mathrm{FAPbI}_{3}(110)$ and $\begin{array}{llllllllll}\delta & -\mathrm{FAPbI}_{3} & (010) & \text { peaks } & \text { (c) } & \text { Crystal structure of the } \alpha \text { and } \delta & \mathrm{FAPbI}_{3}\end{array}$ phases......................................................................................... 141

Figure 7.2. (a) XRD perovskite films $\mathrm{FA}_{1-\mathrm{x}} \mathrm{GA}_{\mathrm{x}} \mathrm{PbI}_{3}$ and (b) zoomed $\mathrm{XRD}$ patterns from 10 to 17 degree 141

Figure 7.3. SEM Image of perovskite films $\mathrm{FA}_{1-\mathrm{x}} \mathrm{GA}_{\mathrm{x}} \mathrm{PbI}_{3}$ a) $0 \% \mathrm{GA}$ b) $2.5 \% \mathrm{GA}$ c) $5 \%$ GA d) $10 \%$ GA e) $20 \%$ GA f) $20 \%$ GA with scale $200 \mathrm{~nm}$ (g-i) TEM Images of perovskite films of $10 \%$ GA 142

Figure 7.4. AFM Images of perovskite films $\mathrm{FA}_{1-\mathrm{x}} \mathrm{GA}_{\mathrm{x}} \mathrm{PbI}_{3}$ (a) $2.5 \%$ (b) $5 \%$ (c) $10 \%$ and (d) $20 \%$ of GA 144

Figure 7.5. (a) UV-Vis absorption spectra of $\mathrm{FA}_{1-\mathrm{x}} \mathrm{GA}_{\mathrm{x}} \mathrm{PbI}_{3}(\mathrm{x}=0,2.5,5,10$ and 20\%) (b) Variations in the optical bandgap for $\mathrm{x} \% \mathrm{GA}: \mathrm{FAPbI}_{3}$ 145

Figure 7.6. (a) $\mathrm{PL}$ of $\mathrm{FAPbI}_{3}$ doped $\mathrm{GA}$ (b) Normalized $\mathrm{PL}$ along with thin films images 146

Figure 7.7. (a, b) XRD and PL of $\mathrm{FAPbI}_{3}$ before and after 2 weeks (c, d) XRD and PL of $\mathrm{FA}_{0.9} \mathrm{GA}_{0.1} \mathrm{PbI}_{3}$ before and after 2 weeks 
Figure 7.8. FESEM of $\mathrm{FAPbI}_{3}$ and $\mathrm{FA}_{0.9} \mathrm{GA}_{0.1} \mathrm{PbI}_{3}$ before and after 2 weeks.....................148

Figure 7.9. Absorbance spectra and photograph of $\mathrm{FA}_{0.9} \mathrm{GA}_{0.1} \mathrm{PbI}_{3}$ fresh and aged of 1 day, 2 days

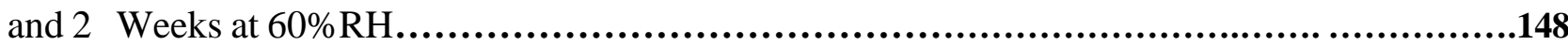

Figure 8.1 1: process for etching the back contact FTO...................................... 159

Figure 8.2 $\mathrm{TiO}_{2}$ compact layer prepared by spray pyrolysis........................................160

Figure $8.1 \mathrm{TiO}_{2}$ mesoporous layer prepared by spin counting $\ldots \ldots \ldots \ldots \ldots \ldots \ldots \ldots \ldots \ldots \ldots \ldots . . \ldots 160$

Figure 8.1: SEM image of Tandem Perovskite/CIGS............................................ 161 


\section{List of tables}

Table 3.1: Specifications of different back contact....................................................66

Table 3.2: Roughness and Grain Size of CIGS films with different back contact....................69

Table 3.3. Optical properties of the CIGS thin films with different back contact......................71

Table 4.1. Optical constants for CISICIGS thin films deposited with spray pyrolysis................82

Table 4.2. The resistivity for CIS/CIGS thin films deposited with spray pyrolysis........................83

Table 4.3: the deposition conditions of sprayed CIGS ..........................................85

Table 4.4: Parameters of XRD of sprayed CIGS films............................................86

Table 4.5: Roughness and Grain Size of CIGS thin films prepared by Spray pyrolysis..............89

Table 4.6 Optical properties of the CIGS thin films...........................................92

Table 4.7: Electrical properties of the CIGS thin films calculated using Van der pauw

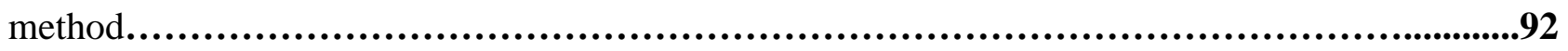

Table 4.8. The parameters of the materials used for the simulation................................94

Table 5.1. Photovoltaic parameters for different CIGS solar cells, including fabrication

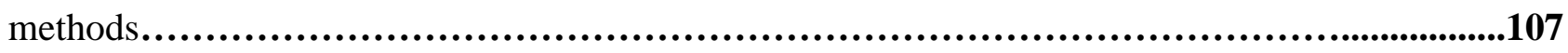

Table 6.1: The grain size, dislocation density and lattice strain of XRD of $\mathrm{MAPbI}_{3}$ thin

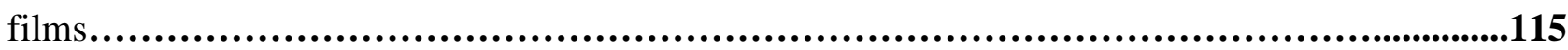

Table 6.2: Band gap of the $\mathrm{MAPbI}_{3}$ thin films with different amounts of antisolvent diethyl ether.

Table 6.3. Lattice parameters of $x \%$ TBA: MaPbI3 via the Pawley method.......................125

Table 6.4 Band gap variation according to TBA content......................................130

Table 7.1. Lattice parameters of $\mathrm{FA}_{1-\mathrm{x}} \mathrm{GA}_{\mathrm{x}} \mathrm{PbI}_{3}$ via the Pawley method................................145

Table 7.2. Band gap variation according to GA content.............................................. 148 


\section{ACKNOWLEDGEMENTS}

Expression of gratitude goes to the place of University Polytechnic de Valencia and Ibn Tofail university for the attention given to my thesis.

I would like to express my deep gratitude to my research directors, professor Bernabe Mari Soucase and professor Mohammed Ebn Touhami, for their moral, technical and financial support, for the professionalism they have shown in their direction as well as for the confidence that 'They were kind enough to testify to me by accepting me as a doctoral student and by giving me special attention and a significant part of their time.

My gratitude is expressed to the members of the research team specially Dr Shafi Ullah, as well as to the friends and colleagues of the characterization laboratory, for their technical and moral support, their academic assistance and their concern for me. expression of my gratitude to the members of my family both for their moral support and their encouragement and more particularly to my father $\mathbf{M r}$ Abdelali Bouich and my mother Lalla Khadija Bririch for their unwavering support and my beloved brother Fouad Bouich and my sisters Meryeme Bouich and Asmaa Bouich and thank you to my Soulmate for his support and for his presence.

I thank my friends who give me joy and happiness every day. I thank my friends for the fact that they continually walk with me. I thank the administrative authorities of the Polytechnic University and Ibn Tofail Faculty of Science for allowing me to continue my doctoral studies. I would like to point out that it was thanks to the help of all these people that I was able to complete my research to obtain the degree of Ph.D.

\section{Dedication}

To my beloved family, Soulmate and Friends 


\section{Summary of thesis:}

The work presented in this thesis is part of the work of the Laboratory of New Materials for Photovoltaic Energy in the main target to use new techniques of elaboration with low cost and using CIGS and Perovskite materials for solar photovoltaic application. This aims to contribute to the development of the exploitation of solar energy for electrical energy by many people around the world. Recently, the enhancement of solar cells efficiency with low cost is a leading to scientific research challenge. Copper, indium, gallium, and selenium (CIGS) solar cells seem to be suitable with low cost and simplified of manufacture. Freshly, $\mathrm{Cu}(\mathrm{In}, \mathrm{Ga})(\mathrm{Se}, \mathrm{S})_{2}$ device record cell efficiency of $23.35 \%$ for thin films solar cells and the efficiency still be boosted. In other hand, Organicinorganic lead halides perovskites ( $\mathrm{APbX} 3$ ) have currently and exceptionally appeared as new materials for low cost thin film solar cells specially that the efficiency of perovskite based solar cell have jumped from $3.8 \%$ to $22.7 \%$ in short time.

In this present work, we report here the experimental investigation on elaboration and characterization chalcopyrite Copper, indium, gallium, and selenium (CIGS) While electrochemical technique and spray pyrolysis as well as methylammonium lead iodide perovskites (MAPbI3) and formamidinuim iodide lead iodide perovskites (FAPbI3) thin films were deposited using the spin coating process for perovskite-based solar cells application and Tandem CIGS-perovskites.

The thin films prepared were characterized by UV-Vis spectroscopy, X-ray diffraction (XRD), Raman spectroscopy (RS), scanning electron microscopy (SEM) and energy dispersive spectroscopy (EDS) analysis, atomic force microscopy (AFM), transmission electron microscopy (TEM), Photoluminescence analysis (PL) and UV-Vis spectroscopy,

The first part of this investigation was devoted for the effect of different parameters on the growth of $\mathrm{Cu}(\mathrm{In}, \mathrm{Ga})(\mathrm{Se}, \mathrm{S}) 2$ grown by electrodeposition. the CIGS absorber film is deposited in one step to optimize the deposition parameters like deposition potential, deposition time and overvoltage of hydrogen on the surface of the deposited cathode also the parameters related to solution such us the concentrations of the precursors and the temperature of the bath and the $\mathrm{pH}$ of the solution also we investigate in details the impact of different back contact was in structural and optical proprieties CIGS thin films. The back contact has a significant effect for the fabrication of CIGS thin films for photovoltaic application.

In a second stage we report the effect of spray pyrolysis technique to control the growth of CIGS films for solar cells application. The chapter is containing two part, first we will study the effect of 
experimental parameter like the concentration of precursors also the annealing process which is the key factor for Improving the performance of solar cells, In the second part, we will investigate the performance of solar cell CIGS, grown by the spray technique, by simulator Scapes to have idea about the efficiency of solar cell before the realization of CIGS solar cell .in this stage we elaborated different thin films constituted CIGS-based solar cells deposited by different techniques. In the objective to accomplish higher power conversion efficiency of the device CdZnS/CdS/CIGS/Mo, the window layer $(\mathrm{ZnO}, \mathrm{CdZnS})$ and the buffer layer $\mathrm{CdS}$ should transmit a large number of photons to reach the absorber layer and generate electrons holes pairs. The approach is to realize another material to change the toxic $\mathrm{ZnO}$ by using correctly the $\mathrm{CBD}$ technique. Moreover, our device $\mathrm{CdZnS/CdS/CIGS/Mo} \mathrm{used} \mathrm{a} \mathrm{transparent,} \mathrm{conductive} \mathrm{CdZnS}$ layer with optimizing the amount of doped materials, which makes it easy to minimize the interface alignment and to illuminate the $p$-n junction.

In other hand, Organic-inorganic lead halides perovskites MAPbI3 and FAPbI3 was investigated in order to optimize the chemical composition and to study the crystallization process also to get sight about the stability of perovskite materials to meet the requirement of their application as an active layer in perovskite solar cell. For this purpose, Crystallization is accomplished by slowing down the solubility in a saturated solution by Adding different amount of diethyl ether Anti-Solvent. the MAPbI3 film surface was treated by adding diethyl ether antisolvent with different rates that directly influences the level of supersaturation and thermal annealing. during the treatment complex exchanges are appearing at the same time under the influence of quite a lot of physicochemical properties. A whole understanding of this topic is critically important for improving solar cell performance. The obtained MAPbI3 perovskite thin films were investigated their optical and electricals properties. The main objective to increase the stability of MAPbI3 thin films, the tetrabutylammonium (TBA) can be successively incorporated into MAPbI3 perovskite films prepared by spin counting technique, boosting the formation of perovskite structure, leading to a higher orientation along the (110) and the identification phase in $110 \mathrm{~cm}-1$.TBA Doped MAPbI3 film shows better crystallinity, large grain size, pinhole-free surface morphology and good roughness, which is suitable for the manufacturing of the optoelectronic devices with higher performance. Also, we have identified the impact of TBA in the photo-physical properties of $\mathrm{MAPbI}_{3}$ perovskite films using photoluminescence technique and UV visible spectroscopy. We have noticed that the TBA improve the photoluminescence emission by reducing the density of trap states and the optical 
absorption indicates a significant shift to the lower wavelength and optical bandgap varied from 1.8 to $1.52 \mathrm{eV}$. Finally, the stability was explored for $5 \%$ TBA, it found that after 15 days the stability remained excellent in a humid environment (relative humidity of $\sim 60 \%$ ). These results would be helpful for realizing stable and high performance $\mathrm{MAPbI}_{3}$-based devices. Furthermore, we investigate the Formamidinium lead iodide $\left(\mathrm{FAPbI}_{3}\right)$ like one of the most attractive perovskite materials, herein we inspect the effect of monovalent cation substitution of Guanidinium (GA) on the structural and optical properties of Formamidinium lead triiodide $\left(\mathrm{FAPbI}_{3}\right)$ thin films perovskites. The ratio between the desirable and black perovskite $\alpha$-phase and the undesirable $\delta$ yellow phase is studied as a function of GA content. GA doping is shown to be efficient in the control of $\alpha / \delta$ phases ratio and then in the stabilization of the $\alpha-\mathrm{FaPbI}_{3}$ phase. We qualitatively evaluate the impact of $10 \%$ of guanidinium on the phase composition and microstructure of films by analyzing perovskite thin films by X-ray diffraction, atomic force microscopy, transmission electron microscopy, photoluminescence and UV-

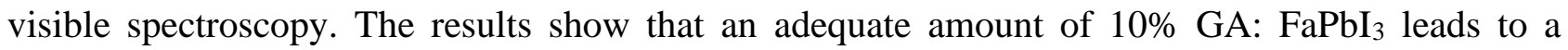
homogeneous perovskite film with stable $\alpha$ phase, large grains, and free pinholes. $10 \% \mathrm{GA}: \mathrm{FaPbI}_{3}$ films demonstrate excellent stability after aging for 15 days in a humid environment (relative humidity of $\sim 60 \%$ ). 


\section{Résumé de la thèse :}

Les travaux présentés dans cette thèse s'inscrivent dans le cadre des travaux au Laboratoire des Nouveaux Matériaux pour l'Énergie Photovoltaïque dans l'objectif principal d'utiliser des nouvelles techniques d'élaboration à faible coût et des matériaux Cuivre Indium Galium Sélénium (CIGS) et Pérovskite pour l'application photovoltaïque. Cela vise à contribuer au développement de l'exploitation de l'énergie solaire pour l'énergie électrique par de nombreuses travaux de recherche à travers le monde. Récemment, l'amélioration de l'efficacité des cellules solaires à faible coût est un défi majeur pour la recherche scientifique. Les cellules solaires au cuivre, à l'indium, au gallium et au sélénium (CIGS) semblent convenir avec un faible coût et une fabrication simplifiée. Dernièrement, les cellules solaires $\mathrm{Cu}(\mathrm{In}, \mathrm{Ga})(\mathrm{Se}, \mathrm{S}) 2$ enregistrent l'efficacité de 23,35\% pour la génération des cellules solaires à couches minces et l'efficacité est toujours en amélioration. D'autre part, les pérovskites aux halogénures de plomb organiques-inorganiques ( $\mathrm{APbX} 3$ ) sont actuellement et exceptionnellement apparus comme des nouveaux matériaux pour les cellules solaires à couches minces à faible coût, d'autant plus l'efficacité des cellules solaires à base de pérovskite est passée de $3,8 \%$ à $22,7 \%$ en peu de temps.

Dans ce présent travail, nous rapportons ici l'enquête expérimentale sur l'élaboration et la caractérisation de la chalcopyrite Cuivre, indium, gallium et sélénium (CIGS) par la technique d'électrodéposition et la technique de pulvérisation ainsi que les pérovskites d'iodure de plomb de methylammonium (MAPbI3) et les pérovskites d'iodure de plomb à l'iodure de formamidinuim ( Des films minces FAPbI3) ont été élaborées en utilisant la technique de revêtement par centrifugation pour l'application de cellules solaires à base de pérovskite et le tandem pérovskites CIGS.

Les films minces préparés ont été caractérisés par spectroscopie UV-Vis, diffraction des rayons $\mathrm{X}(\mathrm{XRD})$, spectroscopie Raman (RS), microscopie électronique à balayage (SEM) et spectroscopie à dispersion d'énergie (EDS), microscopie à force atomique (AFM), transmission électronique microscopie (TEM), analyse de photoluminescence (PL) et spectroscopie UV-Visible.

La première partie de cette thèse a été consacrée à l'effet de différents paramètres sur la croissance des couches minces $\mathrm{Cu}, \mathrm{In}, \mathrm{Ga}(\mathrm{Se}, \mathrm{S}) 2$ élaborées par la technique de l'électrodéposition. Le film absorbant CIGS est déposé en une seule étape pour optimiser les paramètres de dépôt comme le potentiel de dépôt, le temps de dépôt et la surtension d'hydrogène à la 
surface de la cathode déposée également les paramètres liés à la solution tels que les concentrations des précurseurs et la température du bain et le $\mathrm{pH}$ de la solution, nous étudions également en détail l'impact des différents contacts arrière du cellule solaire sur les propriétés structurelles et optiques des films minces CIGS. Le contact arrière a un effet significatif pour la fabrication de couches minces CIGS pour application photovoltaïque.

Dans un deuxième temps, nous rapportons l'effet de la technique de pulvérisation pour contrôler la croissance des films CIGS pour les cellules solaires photovoltaïques. Le chapitre contenant deux parties, d' abord, nous allons étudier l' effet des paramètres expérimentaux comme la concentration des précurseurs également le procédé de recuit qui est le facteur clé pour améliorer les performances des cellules solaires, Dans la deuxième partie, nous allons étudier la performance de l' énergie solaire cellule CIGS, cultivée par la technique du pulvérisation, par le simulateur scapes on a pu avoir une idée sur l'efficacité de la cellule solaire avant la réalisation de la cellule solaire CIGS . ensuite nous avons élaboré différents couches minces constituées les cellules solaires à base de CIGS déposées par différentes techniques. Dans l'objectif d'obtenir une plus grande efficacité de conversion de puissance de la cellule solaire $\mathrm{CdZnS} / \mathrm{CdS} / \mathrm{CIGS} / \mathrm{Mo}$, la couche fenêtre ( $\mathrm{ZnO}, \mathrm{CdZnS}$ ) et la couche tampon $\mathrm{CdS}$ doivent transmettre un grand nombre de photons pour atteindre la couche absorbante et générer des paires de trous d'électrons . L'approche consiste à élaborer un nouveau matériel $\mathrm{CdZnS}$ pour remplacer le $\mathrm{ZnO}$ toxique en utilisant la technique $\mathrm{CBD}$. De plus, notre cellule solaire CdZnS / CdS / CIGS / Mo a utilisé une couche transparente et conductrice de CdZnS en optimisant la quantité de matériaux dopés, ce qui permet de minimiser facilement l'alignement de l'interface et d'illuminer la jonction $\mathrm{p} n$.

D'autre part, les halogénures de plomb organiques-inorganiques pérovskites MAPbI3 et FAPbI3 ont été étudiés afin d'optimiser la composition chimique et d'étudier le processus de cristallisation également pour avoir une vision sur la stabilité des matériaux de pérovskite pour répondre à l' exigence de leur application comme couche active dans cellule solaire pérovskite. A cet effet, la cristallisation est réalisée en ralentissant la solubilité dans une solution saturée en ajoutant une quantité différente d'anti-solvant diméthyle éther. La surface du film MAPbI3 a été traitée en ajoutant un antisolvant de l'éther diéthylique avec des volumes différents qui influencent directement le niveau de sursaturation et de recuit thermique. Au cours du traitement, des échanges complexes apparaissent en même temps sous l'influence de nombreuses propriétés physico-chimiques. Une compréhension globale de ce sujet est d'une importance cruciale pour améliorer les performances des cellules solaires. 
Les films minces de pérovskite MAPbI3 obtenus ont été étudiés leurs propriétés optiques et électriques. dans l' objectif principal d'augmenter la stabilité des films minces MAPbI3, le tétrabutylammonium (TBA) a été successivement incorporé dans les films de pérovskite MAPbI3 préparés par la technique du spin, approuvant la formation de la structure de pérovskite, conduisant à une orientation plus élevée le long du (110) et du phase d'identification de $110 \mathrm{~cm}^{-1}$ dans un film $\mathrm{MAPbI}_{3}$ dopé TBA, aussi $\mathrm{MaPbI}_{3}$ dopé TBA montre une meilleure cristallinité, une grande granulométrie, une morphologie de surface sans piqûre et une bonne rugosité, ce qui convient à la fabrication des dispositifs optoélectroniques avec des performances plus élevées. En outre, nous avons identifié l'impact du TBA dans les propriétés photo-physiques des films de pérovskite MAPbI3 en utilisant la technique de caractérisation photoluminescence et la spectroscopie UV visible. Nous avons remarqué que le dopage avec TBA améliore l'émission de photoluminescence en réduisant la densité des états de piège et l'absorption optique indique un décalage significatif vers la longueur d'onde inférieure et la bande interdite optique varie de 1,8 à 1,52 eV. Finalement, la stabilité a été explorée pour 5\% TBA, il a constaté qu'après 15 jours la stabilité restait excellente dans un environnement humide (humidité relative de $\sim 60 \%$ ). Ces résultats seraient utiles pour réaliser des dispositifs basés sur $\mathrm{MAPbI}_{3}$ stables et à hautes performances. En outre, nous étudions l'iodure de plomb de formamidinium $\left(\mathrm{FAPbI}_{3}\right)$ comme l'un des matériaux de pérovskite les plus attrayants, ici nous inspectons l'effet de la substitution de cations monovalentes du guanidinium (GA) sur les propriétés structurelles et optiques du triiodure de plomb de formamidinium $\left(\mathrm{FAPbI}_{3}\right)$ mince films pérovskites. Le rapport entre la phase $\alpha$ de pérovskite souhaitable noire et la phase $\delta$ indésirable jaune est étudié en fonction de la teneur en GA. Le dopage GA s'avère efficace dans le contrôle du rapport des phases $\alpha / \delta$ puis dans la stabilisation de la phase $\alpha-\mathrm{FaPbI}_{3}$. Nous évaluons qualitativement l'impact de $10 \%$ de guanidinium sur la composition de phase et la microstructure des films en analysant des couches minces de pérovskite par diffraction des rayons $\mathrm{X}$, microscopie à force atomique, microscopie électronique à transmission, photoluminescence et spectroscopie UV-visible. Les résultats montrent qu'une quantité adéquate de $10 \% \mathrm{GA}: \mathrm{FaPbI}_{3}$ conduit à un film de pérovskite homogène avec une phase a stable, de gros grains et des piqûres libres. 10\% GA: Les films $\mathrm{FaPbI}_{3}$ démontrent une excellente stabilité après vieillissement pendant 15 jours en milieu humide (humidité relative $\sim 60 \%$ ). 


\section{Resumen en castellano}

El objetivo principal de esta tesis es contribuir al avance de nuevas técnicas de elaboración con bajo coste, utilizando materiales tipo CIGS y Perovskita para aplicaciones en energía solar fotovoltaica. Recientemente, las células solares de cobre, indio, galio y selenio (CIGS) parecen ser adecuadas ya que son de bajo costo de producción y de fabricación simple y se han reportado eficiencias de conversión del 23,35\%. Por otro lado, las perovskitas híbridas de haluros de plomo orgánicos-inorgánicos $(\mathrm{APbX} 3)$ han aparecido como nuevos materiales excepcionales para celdas solares de película delgada de bajo costo, especialmente porque la eficiencia de las celdas solares basadas en perovskita ha aumentado del $3.8 \%$ al $22.7 \%$ en menos de un lustro.

Este trabajo se ha dedicado a experimentar sobre la elaboración y caracterización de capas finas de la calcopirita de CIGS por la técnica electroquímica y la de espray pirólisis y sobre las perovskitas de metilamonio de yoduro de plomo de $\left(\mathrm{MAPb}_{3}\right)$ y formamidinio de yoduro de plomo $\left(\mathrm{FAPbI}_{3}\right)$ producidas por un proceso de 'spin coating', que se utilizo tanto en la aplicación a las células solares de perovskitas y en las células Tándem CIGS-perovskita.

Las películas de CIGS se caracterizaron por difracción de rayos X (XRD), espectroscopía Raman (RS), microscopía electrónica de barrido (SEM), análisis de espectroscopía de energía dispersiva (EDS), microscopía de fuerza atómica (AFM), transmisión electrónica microscopía (TEM), fotoluminiscencia (PL) y espectroscopia UV-Vis.

En las capas de CIGS depositadas por electrodeposición se investigó el efecto de diferentes parámetros que controlan el proceso de electrodeposición como el potencial, el tiempo de deposición y la sobretensión del hidrógeno en la superficie del cátodo, así como las características del electrolito, concentraciones de los precursores, la temperatura del baño y el pH de la solución. También investigamos en detalle el efecto del contacto posterior en las propiedades estructurales y ópticas de las películas delgadas CIGS. Constatamos que el tipo de contacto posterior tiene un efecto significativo en el rendimiento posterior de las películas delgadas CIGS en los dispositivos fotovoltaicos.

Además, estudiamos la técnica de espray pirólisis para producir películas CIGS. Se estudió el efecto de parámetros como la concentración de precursores y el proceso de recocido, que es el factor clave para mejorar el rendimiento de las células solares. Utilizando el simulador numérico SCAPS, se estimó la eficiencia de la célula solar de capas de CIGS crecidas por espray pirolisis. 
Se elaboraron diferentes películas delgadas constituidas por células solares basadas en CIGS depositadas por diferentes técnicas. Para lograr una mayor eficiencia de conversión del dispositivo $\mathrm{CdZnS/CdS/CIGS/Mo,} \mathrm{tanto} \mathrm{la} \mathrm{capa} \mathrm{ventana}(\mathrm{ZnO}, \mathrm{CdZnS})$ como la capa buffer de CdS deben transmitir una gran cantidad de fotones para que alcancen la capa absorbente y se generen pares electron-hueco. Nuestro dispositivo $\mathrm{CdZnS/CdS/CIGS/Mo} \mathrm{utilizó} \mathrm{una} \mathrm{capa} \mathrm{conductora} \mathrm{transparente}$ de CdZnS con el espesor optimo para minimizar la alineación de la interfaz en la unión p-n.

Por otro lado, se investigaron perovskitas de yoduro de plomo con dos componentes orgánicos diferentes, metilamonio y formamidinio, $\mathrm{MAPbI}_{3}$ y $\mathrm{FAPbI}_{3}$. Se analizó la composición química, el proceso de cristalización y la estabilidad de las capas. La mejora de la cristalización se logra ralentizando el proceso mediante la adición de antisolvente de éter dietílico. Las capas de $\mathrm{MAPbI}_{3} \mathrm{se}$ trataron añadiendo antisolvente a diferentes velocidades que influyen directamente en el nivel de sobresaturación y con recocido térmico. Durante el tratamiento se producen intercambios complejos que influencian muchas propiedades fisicoquímicas. Una comprensión completa de este tema es de vital importancia para mejorar el rendimiento de las células solares. Se investigaron las propiedades ópticas y eléctricas de las películas delgadas de perovskitas de MAPbI3 obtenidas.

Para mejorar la estabilidad de las películas delgadas de MAPbI3 se incorporó tetrabutilamonio (TBA), observando una mejora en la formación de la estructura perovskita que crece en la dirección preferente (110). La fase cristalina de la película de $\mathrm{MAPbI}_{3}$ dopada con TBA presenta mejor cristalinidad, gran tamaño de grano, morfología superficial sin poros y baja rugosidad, lo que es adecuado para la fabricación de dispositivos optoelectrónicas con mayor rendimiento. Además, hemos identificado el impacto de TBA en las propiedades foto físicas de las películas de perovskita $\mathrm{MAPbI}_{3}$ utilizando las técnicas de fotoluminiscencia y espectroscopia óptica UV-visible. En las muestras de TBA:MAPbI 3 aumenta la intensidad de la fotoluminiscencia al reducir la densidad de los estados de trampa y la absorción óptica muestra un cambio significativo hacia longitudes de onda más largas y la banda prohibida óptica varió de 1.8 a 1.52 eV. Finalmente, las muestras dopadas con TBA al 5\% mejoraron su estabilidad y se encontró que después de 15 días la estabilidad permanecía excelente en un ambiente húmedo (humedad relativa de $\sim 60 \%$ ). Estos resultados serían útiles para realizar dispositivos basados en $\mathrm{MAPbI}_{3}$ estables y de alto rendimiento.

Por otra parte, investigamos el efecto de la sustitución catiónica monovalente de guanidinio (GA) sobre las propiedades estructurales y ópticas de las perovskitas de películas delgadas de $\mathrm{FAPbI}_{3}$. La relación entre la fase $\alpha$ de perovskita negra y deseable y la fase amarilla indeseable $\delta$ se ha 
estudiado en función del contenido de GA. Se comprobó que el dopaje con GA es eficaz en el control de la relación de fases $\alpha / \delta$ y luego en la estabilización de la fase $\alpha$. Evaluamos cualitativamente el impacto del 10\% de guanidinio en la composición de fases y microestructura de películas analizando las capas por difracción de rayos X, microscopía de fuerza atómica, microscopía electrónica de transmisión, fotoluminiscencia y espectroscopía UV-visible. Los resultados muestran que añadiendo una cantidad adecuada del $10 \%$ de GA en las capas de $\mathrm{GA}_{\mathrm{FaPbI}} \mathrm{F}_{3}$ conduce a una mejora de película de perovskita que se evidencia en la homogeneidad de la fase $\alpha$ estable, granos de mayor tamaño y capas libres de poros. Además, las películas de 10\% $\mathrm{GA}: \mathrm{FaPbI}_{3}$ demostraron una excelente estabilidad después de ser envejecidas durante 15 días en un ambiente con humedad relativa del $60 \%$. 


\section{Resum en valencià}

El treball presentat en aquesta tesi forma part del treball del Laboratori de Nous Materials per a Energia Fotovoltaica amb l'objectiu principal d'utilitzar noves tècniques d'elaboració de materials de baix cost i utilitzant capes fines de CIGS i de Perovskites per a aplicacions en energia solar fotovoltaica. Aquest objectiu principal s'adreça a contribuir al desenvolupament de l'explotació de l'energia solar com a font neta i inesgotable d'energia elèctrica per part de moltes persones a tot el món. En este sentit, la millora de l'eficiència de les cèl-lules solars a baix cost és un desafiament per a la investigació científica. Les cèl-lules solars de coure, indi, gal-li i seleni (CIGS) semblen ser adequades amb un baix cost i una fabricació simplificada. Recentment, dispositius basats en capes fines de $\mathrm{Cu}(\mathrm{In}, \mathrm{Ga})(\mathrm{Se}, \mathrm{S})_{2}$ han registrat una eficiència de conversió del 23,35\% i esta eficiència encara continua incrementant-se. D'altra banda, les perovskitas d'halurs de plom orgànics-inorgànics $\left(\mathrm{APbX}_{3}\right)$ han aparegut com a nous materials excepcionals per a cel-les solars de pel-lícula prima de baix cost, especialment perquè l'eficiència de les cel-les solars basades en perovskita ha augmentat del $3.8 \%$ al $22.7 \%$ en menys d'un lustre.

En el present treball, reportem la investigació experimental sobre elaboració i caracterització de calcopirita Coure, indi, gal-li i seleni (CIGS) per mitjà de la tècnica electroquímica i per esprai piròlisi. Quant a les perovskitas de iodur de plom de metilamonio $\left(\mathrm{MAPbI}_{3}\right)$ i les perovskitas de iodur de plom i iodur de formamidinuim es van depositar pel-lícules primes fent servir un procés de recobriment per rotació. Les cèl·lules solars tipus tàndem basades en perovskites i CIGS s'han construït utilitzant les dues tècnics mencionades abans.

Les pel-lícules primes preparades es van caracteritzar per espectroscòpia òptica UV-Vis, difracció de raigs $\mathrm{X}(\mathrm{XRD})$, espectroscòpia Raman (RS), microscòpia electrònica d'escombratge (SEM) i anàlisi de espectroscòpia d'energia dispersiva (EDS), microscòpia de força atòmica (AFM), transmissió electrònica microscòpia (TEM) i fotoluminiscència (PL).

La primera part d'aquesta investigació es va dedicar a aquest efecte de diferents paràmetres sobre el creixement de $\mathrm{Cu}(\mathrm{In}, \mathrm{Ga})(\mathrm{Se}, \mathrm{S})_{2}$ crescut per electrodeposició. La pel-lícula absorbent de CIGS es va depositar en un sol pas i es van optimitzar els paràmetres de deposició com ara, el potencial de deposició, el temps de deposició. Els paràmetres relacionats amb l'electròlit com son ara les concentracions dels precursors, la temperatura del bany i el pH de la solució també s'han investigat detalladament així com l'impacte dels diferents substrats (o contactes posteriors) en les propietats 
estructurals i òptiques de les pel·lícules primes CIGS. Hem demostrat que el contacte posterior té un efecte significatiu per a la fabricació de pel-lícules primes CIGS per a aplicacions fotovoltaiques.

En una segona etapa hem investigat l'efecte de la tècnica de l'esprai piròlisi per a controlar el creixement de pel·lícules CIGS i la seua aplicació a les cèl·lules solars. Este capítol conté dues parts, en el primer es va estudiar l'efecte de paràmetres experimentals com la concentració de precursors i també el procés de recuita, que és el factor clau per a millorar el rendiment de les cèl·lules solars. En la segona part, investigarem el rendiment de les cèl·lules solars de CIGS crescudes mitjançant la tècnica d'esprai i es va fer servir el simulador numèric SCAPS per a tindre idea de l'eficiència de la cèl-lula solar abans de la realització de la pròpia cèl-lula solar de CIGS. En aquesta etapa es van elaborar diferents pel·lícules primes constituïdes per cèl·lules solars basades en CIGS depositades per diferents tècniques. En l'objectiu d'aconseguir una major eficiència de conversió d'energia del dispositiu CdZnS / CdS / CIGS / Mo. La capa de la finestra òptica ( $\mathrm{ZnO}, \mathrm{CdZnS})$ i la capa buffer (CdS) han de transmetre una gran quantitat de fotons per a aconseguir la capa absorbent i generar parells de buits d'electrons. L'enfocament és realitzar un altre material per a canviar el $\mathrm{ZnO}$ tòxic utilitzant correctament la tècnica de CBD. A més, el nostre dispositiu CdZnS / CdS / CIGS / Mo va utilitzar una capa de $\mathrm{CdZnS}$ conductora transparent que optimitza la quantitat de materials dopats, la qual cosa facilita minimitzar l'alineació de la interfície i il·luminar la unió p-n.

D'altra banda, es van investigar perovskites híbrides d'halogenurs de plom orgànicsinorgànics MAPbI3 i FAPbI3 amb la finalitat d'optimitzar la composició química i estudiar el procés de cristal- lització també per a conèixer l'estabilitat dels materials de perovskita per a complir amb els requisits de la seua aplicació com a capa activa en cèl·lules solars de perovskita. Per a aquest propòsit, la cristal-lització s'aconsegueix alentint la solubilitat en una solució saturada mitjançant l'addició d'una quantitat diferent de l'antisolvent d'èter dietílic. La superfície de la pel·lícula MAPbI3 es va tractar afegint l'antisolvent d'èter dietílic amb diferents velocitats que influeixen directament en el nivell de sobresaturació i recuit tèrmic. Durant el tractament apareixen al mateix temps intercanvis complexos sota la influència de moltes propietats fisicoquímiques. Una comprensió completa d'aquest tema és de vital importància per a millorar el rendiment de les cèl-lules solars. Es van investigar les propietats òptiques i elèctriques de les pel-lícules primes de les perovskites de $\mathrm{MAPbI}_{3}$ obtingudes.

Amb l'objectiu principal d'augmentar l'estabilitat de les pel-lícules primes de $\mathrm{MAPbI}_{3}$, el tetrabutilamoni (TBA) es pot incorporar successivament a les pel·lícules de perovskita de $\mathrm{MAPbI}_{3}$ preparades mitjançant la tècnica de 'l'espín coating', impulsant la formació de l'estructura de 
perovskita, la qual cosa porta a una major orientació al llarg de (110). Les pel-lícules de $\mathrm{MAPbI}_{3}$ dopades amb TBA presenten una millora de la cristalinitat, major grandària de gra, una morfologia superficial sense porus i bona rugositat, la qual cosa és adequada per a la fabricació de dispositius optoelectròniques de major rendiment. A més, hem identificat l'impacte de TBA en les propietats foto físiques de les pel-lícules de perovskita MAPbI3 utilitzant les tècniques de fotoluminiscencia i espectroscòpia UV visible. Hem notat que el dopatge amb TBA millora tant l'emissió de la fotoluminiscencia en reduir la densitat dels estats de trampes com l'absorció òptica on apareix un canvi significatiu de la banda òptica prohibida (gap) cap a longituds d'ona més llargues que significa disminuir l'energia del gap, que va variar de 1.8 a $1.52 \mathrm{eV}$.

Finalment, es va explorar l'estabilitat per les perovsquites dopades amb TBA al 5\%. Es va trobar que després de 15 dies l'estabilitat romania excel·lent en un ambient humit (humitat relativa de 60\%). Aquests resultats han resultats molt útils per a realitzar dispositius basats en $\mathrm{MAPbI}_{3}$ estables i d'alt rendiment.

A més, hem estudiat el iodur de plom de formamidinio $\left(\mathrm{FAPbI}_{3}\right)$ com un dels materials de perovskita més atractius. Hem investiguat l'efecte de la substitució catiònica monovalent de guanidini (GA) sobre les propietats estructurals i òptiques de les perovskitas de pel-lícules primes de triyodur de plom de formamidini $\left(\mathrm{FAPbI}_{3}\right)$. La relació entre la fase $\alpha$ de perovskita negra i desitjable i la fase groga indesitjable $\delta$ es va estudiar en funció del contingut de GA. Es mostra que el dopatge amb GA és eficaç en el control de la relació de fases $\alpha / \delta$ i després en l'estabilització de la fase $\alpha-\mathrm{FaPbI}_{3}$. Avaluem qualitativament l'impacte del 10\% de guanidini en la composició de fases i microestructura de pel-lícules analitzant pel-lícules primes de perovskita per difracció de raigs $\mathrm{X}$, microscòpia de força atòmica, microscòpia electrònica de transmissió, fotoluminiscencia i espectroscòpia UVvisible. Els resultats mostren que una quantitat adequada de $10 \%$ GA: $\mathrm{FaPbI}_{3}$ condueix a una pel-lícula de perovskita homogènia amb fase $\alpha$ estable, grans grans lliures de porus i forats. Les pel-lícules de $10 \% \mathrm{GA}: \mathrm{FaPbI}_{3}$ demostraren una excel-lent estabilitat després de l'envelliment durant 15 dies en un ambient humit (humitat relativa de 60\%). 


\section{Chapter I:}

\section{Overview of Solar Cells Applications}

\section{Contents}

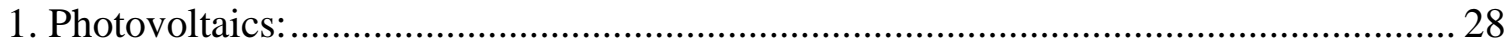

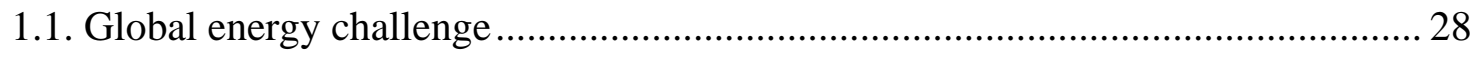

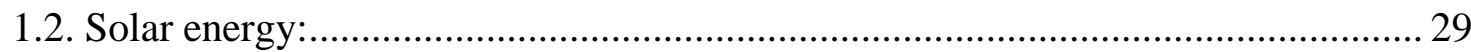

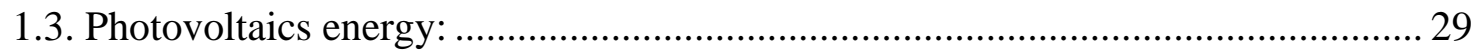

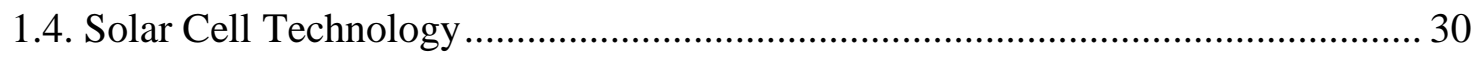

1.4.1. First generation: crystalline Si solar cells ........................................................ 30

1.4.2. Second PV Generation: thin film solar cells.................................................... 31

1.4.3. 3rd Generation PV: perovskite solar cells ....................................................... 31

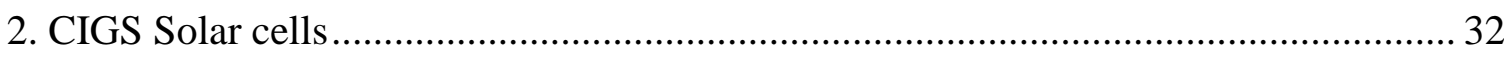

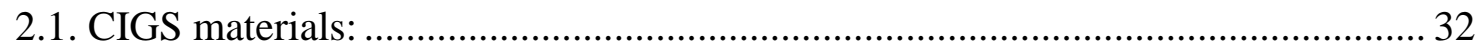

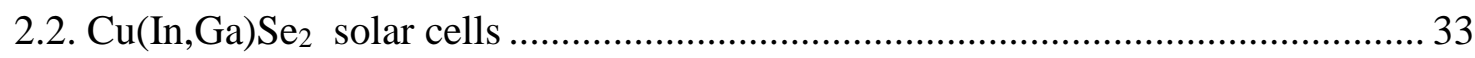

2.3. Energy band diagram of $\mathrm{Cu}(\mathrm{In}, \mathrm{Ga}) \mathrm{Se}_{2}$ solar cells. ................................................ 33

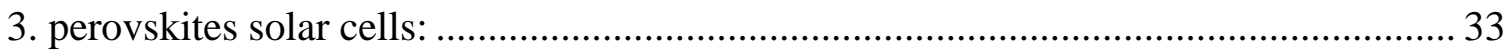

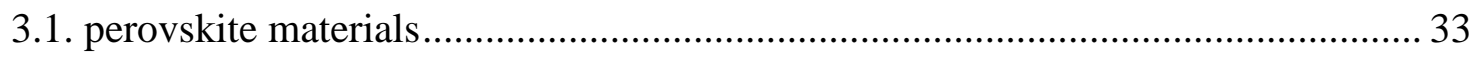

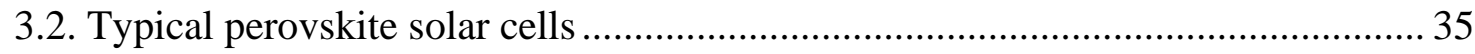

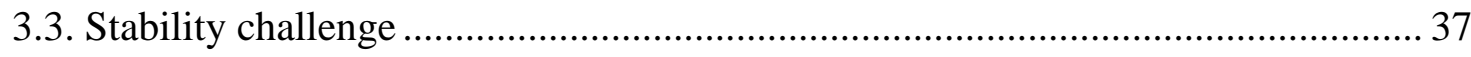

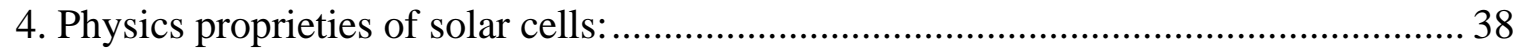

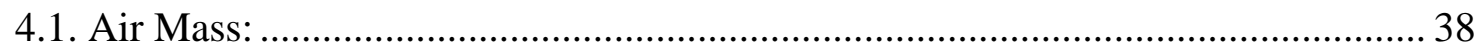

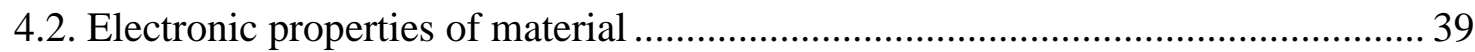

4.3. Direct and indirect bandgap semiconductors ............................................................ 39

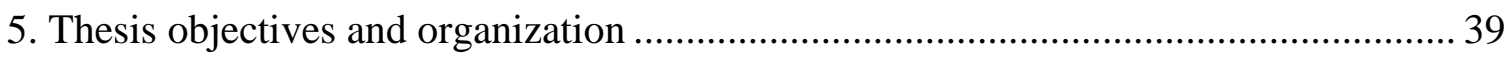




\section{Photovoltaics:}

\subsection{Global energy challenge}

The energy has become a permanent concern due to rapid growth in industrialization in recent years especially with high energy consumption [1]. in recent years, the large percentage of world energy demand is produced from the combustion of fossil fuels which run out dramatically in nature in the absence of an oil or coal reserve [2].

These fossil fuels which produce dangerous greenhouse gases during combustion, which results in tragic environmental pollution and is causing global warming and climate change which threatens life on earth. in the sense of reducing the consumption of fossil fuels, renewable energies can be an alternative source and a good solution to reduce $\mathrm{CO}_{2}$ in the atmosphere especially that global warming caused by the releases of industries has a harmful effect on the layer of the ozone. As we know that the ozone layer stops the UV radiation, despite the fact the radiation gone from the Sun to the Earth. Then, the solar energy is an alternative and inexhaustible source without pollution (Figure 1.1).

the annual energy is approximately $1018 \mathrm{kWh}$ comes from the Sun and received by the Earth, it is approximately 20000 times more than the annual energy consumption of the world, Solar energy is an unlimited, non-polluting source and may well provide the energy demanded by the worldwide in the near future [3]. 

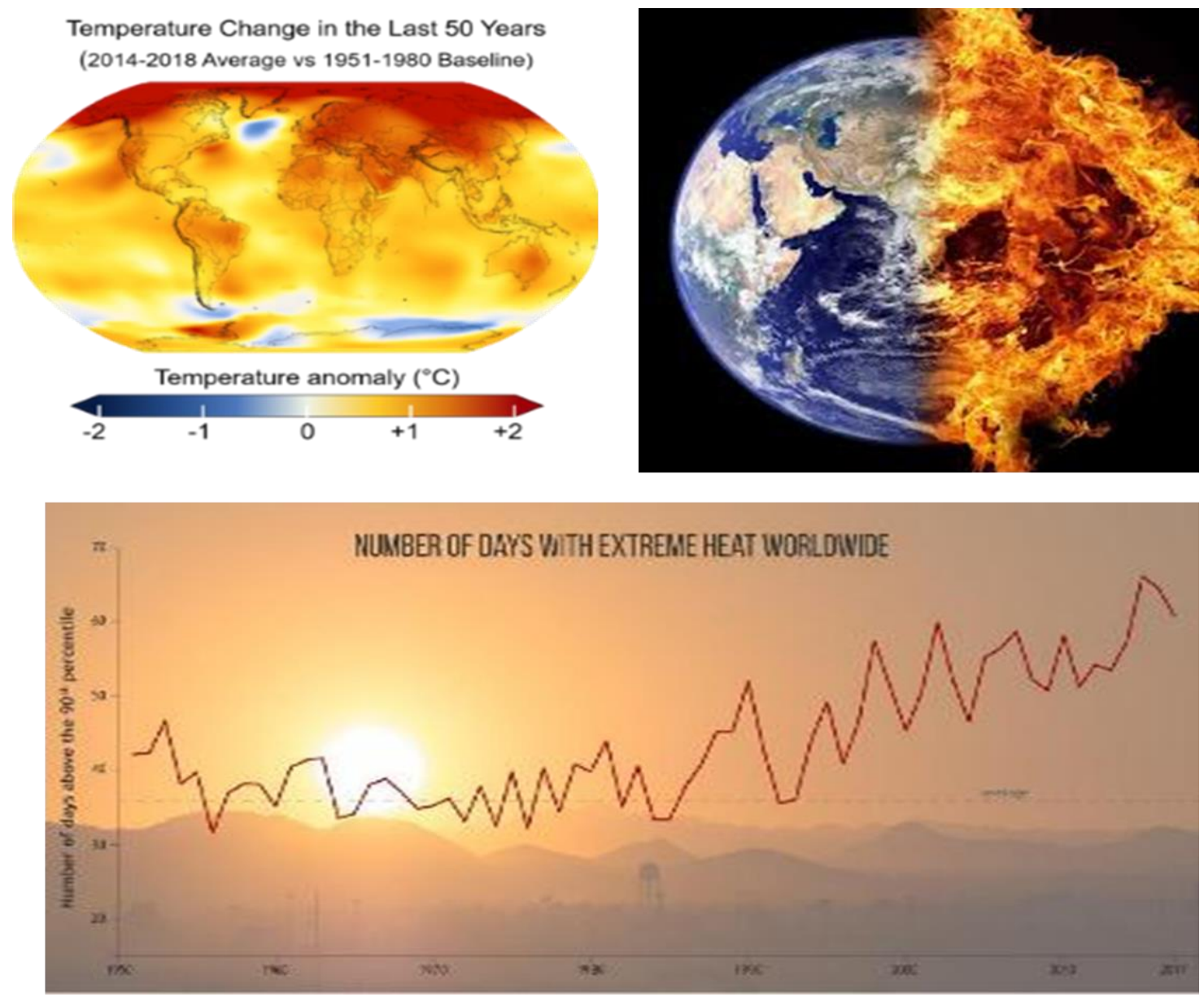

Figure 1.1 Global warming and climate change

\subsection{Solar energy:}

Solar energy is an available source of energy that can be used as solar radiation or as wind, biomass, etc. the surface of the earth receives approximately $60 \%$ of solar energy although only $0.1 \%$ of this emitted energy can be converted to a yield of $10 \%$ but it remains four times much more than the world production capacity of electricity figure 1.2. Researchers around the world have put a lot of effort into finding good sources of energy without affecting future environmental sustainability and life on our planet. Renewable energies are a relevant solution for the future, commonly classified into wave, hydraulic, tidal, wind and solar energy especially that the sun generates enormous amounts of energy about $1026 \mathrm{~W}$ [4].

In the last years solar energy has experienced a high use due to the lower costs of solar panel technology. For case, between 2000-2019 PV capacity has amplified in the USA from 117.3 MWP to 75,999 MWP, between 2010-2017 in Germany from 114 MW to 42339 MW, in Morocco from 20 MW to 6000 MW between 2010 and 2020, and in Spain 3,840 MW and 11,015 MW between 2010 
and 2016, this progress has encouraged many countries to make more investment in renewable energies field by developing photovoltaic devices with different materials [5][6].

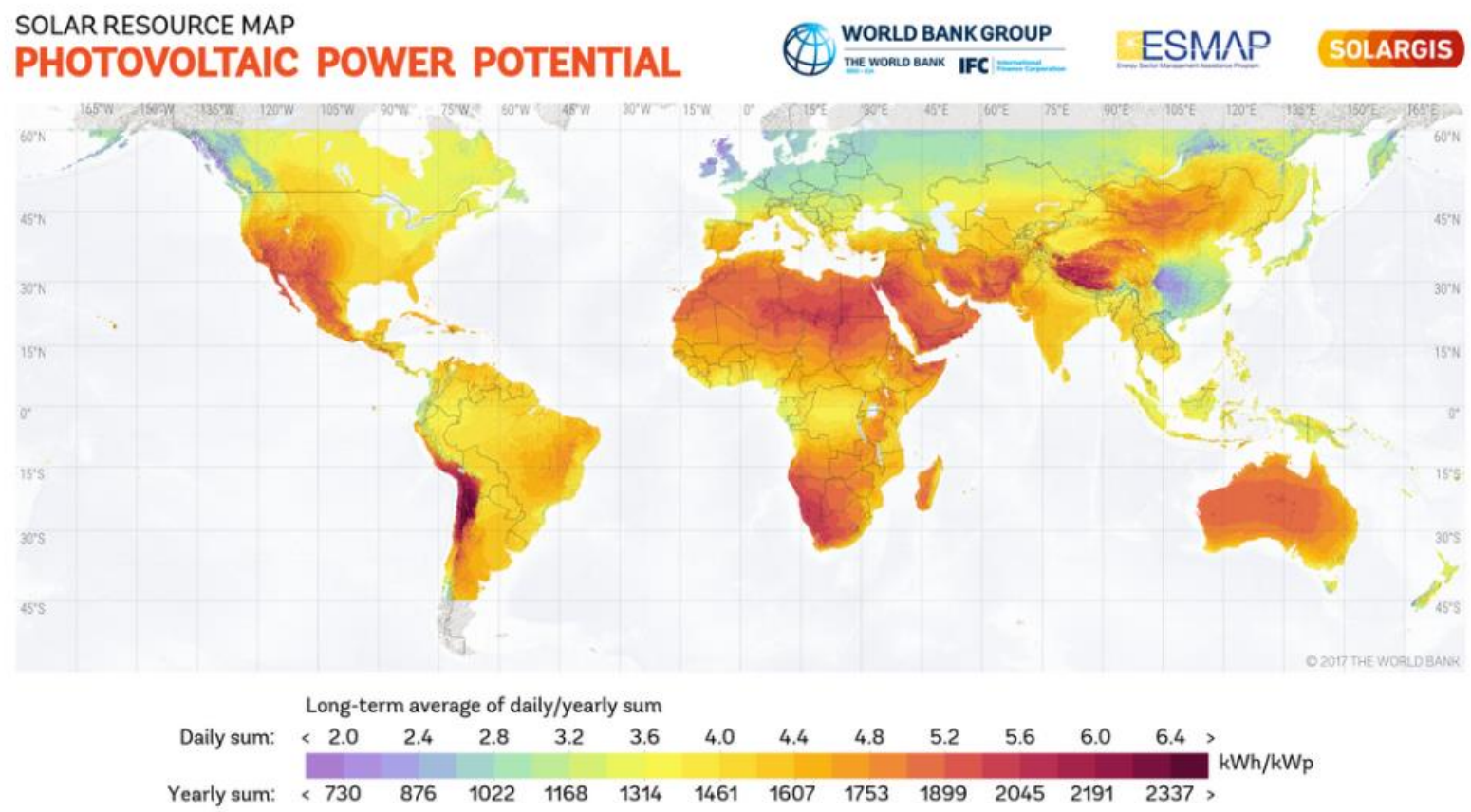

Figure 1.2 photovoltaic energy power

\subsection{Photovoltaics energy:}

Photovoltaic energy that it is coming from the conversion of the solar radiations into electrical energy with a suitable efficiency. Sun rays comes as photons at the Earth's surface and are absorbed or reflected.

Photovoltaic device converts the sun light into electricity by semiconductors materials. There are quite a lot of different solar cells technologies but solid-state semiconductor solar cell is used a lot, in this case the absorber film may be an amorphous, crystalline, or polycrystalline semiconductor. In particular Silicon and GaAs solar cells are the most efficient.

In recent years perovskite $\mathrm{ABX}_{3}$ and $\mathrm{Cu}$ (In, Ga) $\mathrm{Se}_{2}$ (CIGS) materials take much intention from the researchers due the absorption proprieties and reducing thickness layer from $100 \mu \mathrm{m}$ to few $\mu \mathrm{m}$ properties. This make them to fabricate solar panels with low cost by using simple techniques. Semiconductors materials constitute by valence band (Bv) and conduction band (Bc) where they are disconnected by a forbidden gap of energies, named by the band gap $\mathrm{Bg}$. at $0 \mathrm{~K}$ temperature the $\mathrm{Bv}$ has a full of electrons besides Bc is an unfilled [7]. 


\subsection{Solar Cell Technology}

The investigation on photovoltaic solar cells was motivated by the main objective of efficiency improvement for autonomous applications as Shown in figure 1.3. solar cells are classified into three generations with very intense research for each one to develop the three generations on three levels: increase the yield, low cost fabrication and respect the environment by reducing the use of toxic materials [8][9].

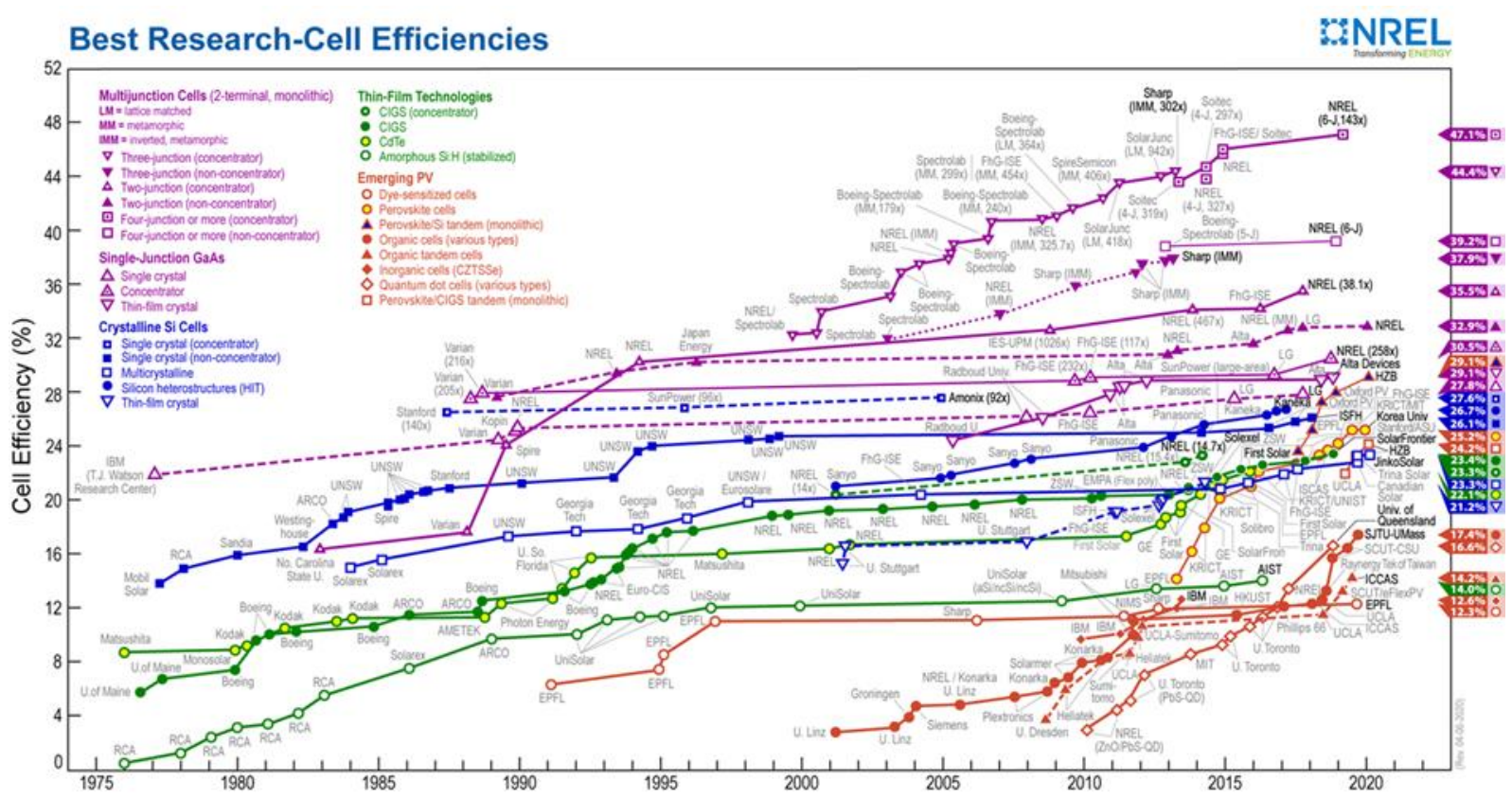

Figure 1.3 shows the progress of the best research-solar cell efficiencies since beginning of photovoltaic energy to nowadays for the different generations.

\subsubsection{First generation: crystalline $\mathrm{Si}$ solar cells}

The first-generation crystalline $\mathrm{Si}$ (c-Si) solar cells efficiencies varied from $6 \%$ for amorphous silicon-based solar cells to $44.0 \%$ with multiple-junction production cells. Extraction and growth of pure silicon crystals is an expensive process and one the high cost is major challenge also the efficiency increase with the higher temperature for the monocrystalline silcon solar cell. Polycrystalline silicon solar cells are elaborated from multiple silicon crystals in mold with the cost low but with a decrease in efficiency compare to mono-crystallin. But Even the efficiency of crystalline $\mathrm{Si}$ (c-Si) solar cells up of $44 \%$ however the cost of first-generation technology is still higher [10][11].

\subsubsection{Second PV Generation: thin film solar cells}


The Second generation solar cells based in thin film technologies which amorphous $\mathrm{Si}(\mathrm{a}-\mathrm{Si}$ ), polycrystalline $\mathrm{CdTe}$, and polycrystalline $\mathrm{Cu}(\mathrm{In}, \mathrm{Ga}) \mathrm{Se}_{2}$ (CIGS) lead the second generation as the best generation intel now by fitting the requirement of low cost manufacture and one advantage of thin film technology that solar cell can be formed by simple and advance techniques like electrochemical deposition, chemical bath deposition, spray pyrolysis, spin counting. The second-generation solar cells are integrated the industrial sector due to the rapidity and the large area of production with low cost specially that the layers are quite thin leading to reduce the manufacture cost[12].

There are three divisions of thin film solar cells: amorphous silicon a-Si, cadmium telluride CdTe and the chalcopyrite compounds like copper indium gallium (di) selenide (CIGS) a-Si is the first-born thin-film solar cell. It is no toxic and absorbs well but their highest efficiency is around $13.6 \%$ because of quick the efficiency lost. CdTe is the most common thin-film solar cell, CdTe cell efficiency is about $22.1 \%$, and however, cadmium and tellurium are the rare metals. CIGS solar cells are formed via co-evaporation or co-deposition. CIGS Solar cell has gotten the record of $22.9 \%$ efficiency.[13]

\subsubsection{3rd Generation PV: perovskite solar cells}

Solar cells looking to get more than the Shockley-Queisser limit of 31-41\% efficiency known as the third generation of solar cells [14]. This challenge is created due to the efficiency limitation of first-generation technology and second generation based in single layer. Third generation technology is generally included multi-layer (tandem) cells that common made of silicon/thin film hierarchy of a solar cell which the thin film could be CIGS Copper zinc tin sulfide solar cell (CZTS), Perovskite solar cell, especially this last one has received large attention as their research efficiencies recently is above 20 percent.[15]

\section{CIGS Solar cells}

In 1970 for the first of time group of researchers at the University of Delaware in the United States was introduced the technology of thin-film solar cells. In recent years thin film solar cells incessantly enhanced efficient, subsequently in the early 21 st century the thin-film photovoltaic market was growing significantly. Nowadays, amorphous silicon, polycrystalline copper indium gallium diselenide (CIGS) and cadmium telluride (CdTe) are the most used to made commercial thinfilm cells. These materials show good potential for low cost manufacture solar cells, Thin-film solar cell formed by little material with the main advantage of being simple and easy production. For any technology qualification in point of the view of cost-per-watt, the ease of production, the highest efficacity, accessibility of materials, and environmental sensitivity are Important points to evaluate.in 
this case the thin-film technology has possibility to turn out to be economically useful and helpful technology for the solar energy future [16][17].

Quite a lot of deposition procedures are applicable and available, they are actually inexpensive compare to the growth techniques obligatory used for crystalline silicon. These deposition methods can simply be scaled up from laboratory scale to industrial scale. The films can be elaborated on numerous cheaper substrates. These can be conductor or normal glass or flexible plastic. For the thinfilm solar cell elaboration is made as single a unit. Film upon film is placed sequentially on a glass substrate as back contact of cell, from the antireflection coating and conducting oxide, to the semiconductor material, to the back electrical contacts. The electrical contact for the thin film solar cell usually is a thin film of a conducting oxide, such as tin oxide FTO, indium tin oxide ITO, and zinc oxide $\mathrm{ZnO}$, are transparent and conduct electricity. They assemble the current from the top of the cell and losses when the resistance is minimal. An antireflection coating can be used to top off the solar cell [18][19].

\subsection{CIGS materials:}

Copper indium gallium diselenide $\mathrm{Cu}(\mathrm{ln}, \mathrm{Ga}) \mathrm{Se}_{2}$ has very high absorptivity $\left(10^{5} \mathrm{~cm}^{-1}\right)$ Many efforts was made to push of CIGS thin-films for manufacturing and commercialization of the CIGS solar cells. Electrodeposition is one of technique that has shown to produce CIGS solar cells with good efficiency and high performance [20] that absorbs in the one micron of the area of the thin film around $99 \%$ of the incident light. Furthermore $\mathrm{Cu}(\mathrm{ln}, \mathrm{Ga}) \mathrm{Se}_{2}$ has revealed good stability and no degradation of the materials as one of the conditions for the commercialization in photovoltaic market [21]. CdS materials is usually used like window layer for CIGS solar cell and in some case small amount of $\mathrm{Zn}$ is doped $\mathrm{CdS}$ to enhance the transparency [22]. The CIGS thin film comprises quaternary materials copper, indium, gallium and selenium or sulfur. several techniques were used to elaborate CIGS thin films such as ablation laser [23] single-source evaporation [24], spin coating [25], co-evaporation [26,27], flash evaporation [28], RF sputtering [29], electrodeposition [30], spray pyrolysis [31,32]. Taking in consideration the other techniques, chemical electrodeposition method showed several advantages and strengths to be noticed, such as high-quality deposition and speed, large-area films and low cost, several investigation in solar cells focus to develop thin films by electrodeposition technique and to produce solar cell panels and modules at low cost to cut down the expense cost of others techniques [33].

\section{2. $\mathrm{Cu}(\mathrm{In}, \mathrm{Ga}) \mathrm{Se}_{2}$ solar cells}



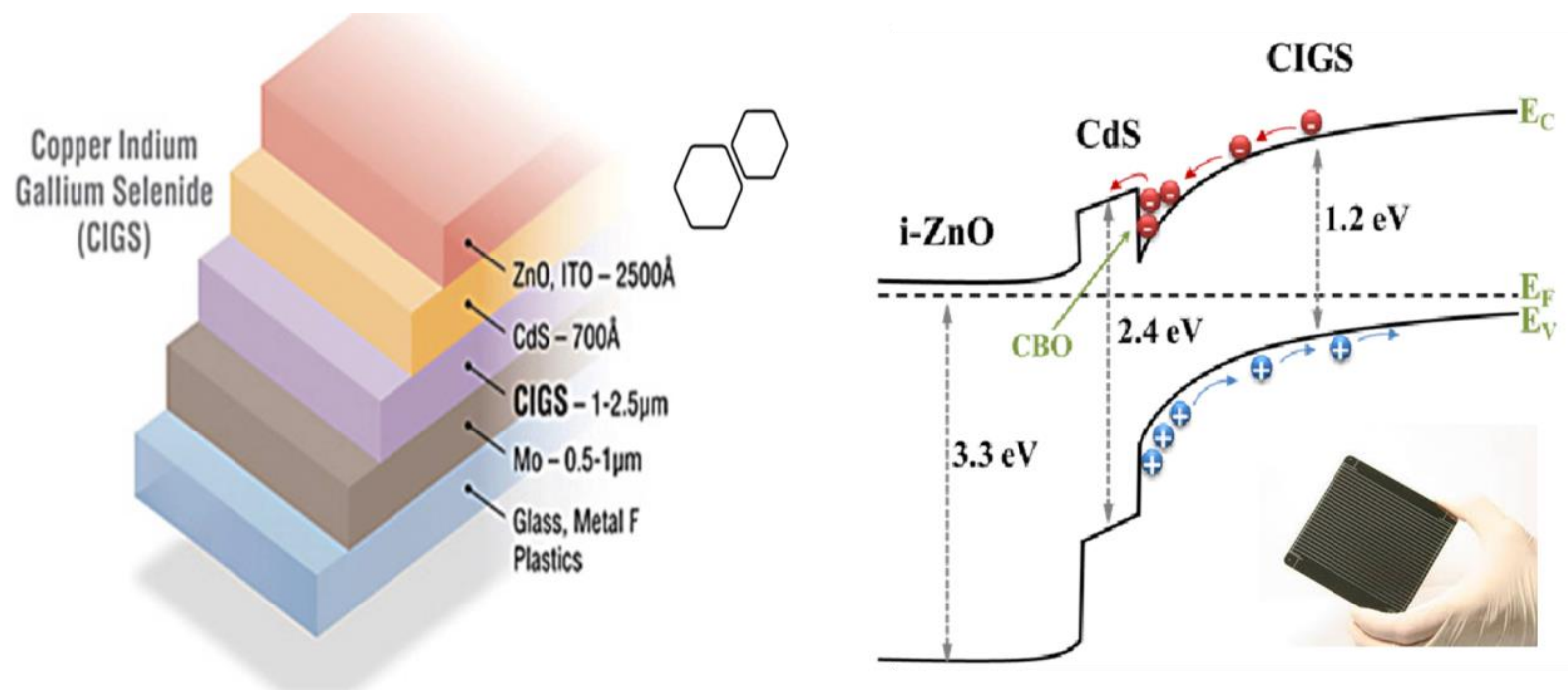

Figure 1.4 Typical CIGS solar cell Devices and Band Diagram of CuInGaS / CdS /ZnO

Figure 1.4 shows Typical CIGS device uses as front contact, the transparent conductive oxides like $\mathrm{ZnO}$ and as back contact the Molybdenum on a silica-glass substrate, front and back contacts formed by sputtering or chemical vapor deposition techniques. The heterojunction created by the ptype CIGS thin film absorber and the n-type window layer but in this case CIGS device shows very poor performance. Then, A layer CdS turns as a buffer layer and acts important role to maintain the heterojunction in CIGS devices and show high efficiency, the CdS layer plays key role to keep the absorber layer safe from degradation and the chemical reactions and to improve the stability of cell. The CdS buffer layer helps in widening the depletion layers at the interface allowing a higher open circuit voltage (Voc). It also helps in optimizing the band alignment of the device [34]. The CdS films deposited by Chemical bath deposition technique exhibit highly efficient CIGS device [34].

The bandgap is increased by doping with small amount of Guanidinium also the increased bandgap of CdS can decrease the energy loss in CdS/CIGS interface in recombination [35,36] therefore increase the solar cell performance.

\section{3. perovskites solar cells:}

\section{1. perovskite materials}

A perovskite is material with crystal structure like calcium titanium oxide (CaTiO3) which was exposed in 1839 by Gustav Rose and named after the Russian mineralogist L. A. Perovski, perovski name was given to the most important family of organic-inorganic hybrid materials with the formula compounds $\mathrm{ABX} 3$, where ' $\mathrm{A}$ ' and ' $\mathrm{B}$ ' are two cations with different sizes where $\mathrm{A}$ is normally large 
cation compare to $\mathrm{B}$ cation, and $\mathrm{X}$ is an anion. The ideal cubic structure has the $\mathrm{B}$ cation in 6-fold coordination, surrounded by an octahedron of anions, and the A cation in 12-fold cub octahedral coordination (figure 1.6) [37].
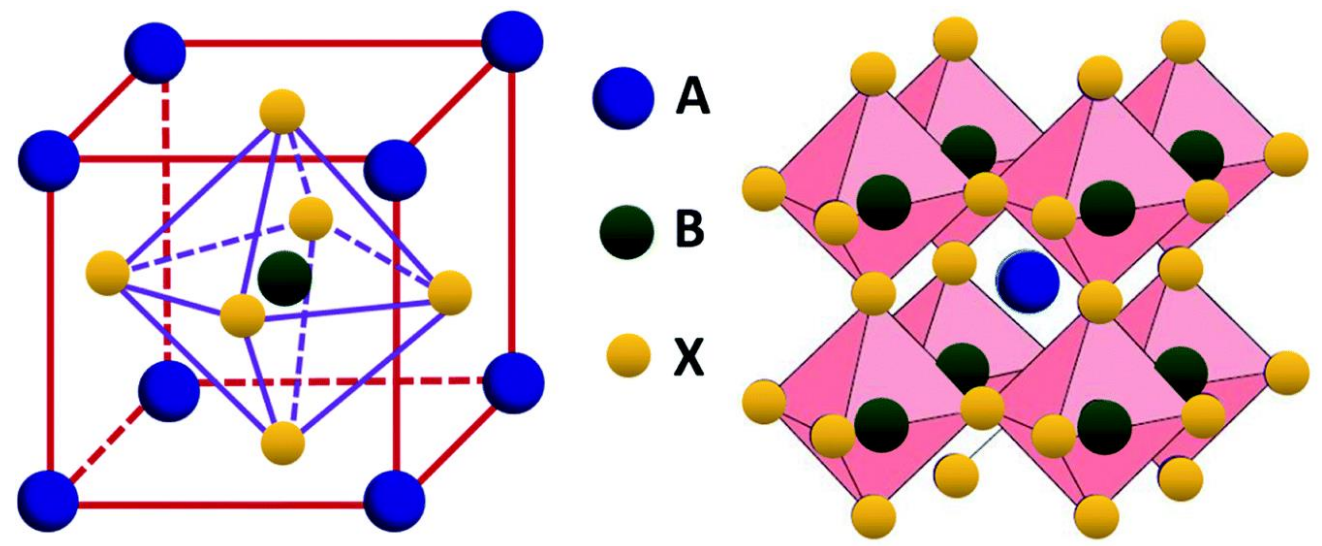

Figure 1.6 Crystal structure of an organic-inorganic metal halide perovskite

The importance of perovskites has been increasing. Currently, several materials are identified adopting the perovskite crystal structure. Successive efforts to advance the material properties have engaged with the result of new structures showing suitable physic-chemical properties. These compounds are the typical systems for phases transitions with cubic, tetragonal, orthorhombic, trigonal relating on the tilting and rotation of the $\mathrm{BX} 3$ polyhedra in the lattice.

The hybrid halide perovskites represented an original kind of perovskite compounds where the structure comprises an organic and metal part, that they have suitable properties of organic semiconductors. Figure 1.7 shows the crystal structure of an organic-inorganic metal halide perovskite $\mathrm{ABX} 3$, where A represents the organic cation, B denotes lead $(\mathrm{Pb})$, tin $(\mathrm{Sn})$ or germanium $(\mathrm{Ge})$, and $\mathrm{X}$ is halide $(\mathrm{X}=\mathrm{I}, \mathrm{Br}, \mathrm{Cl})$. The hybrid halide perovskites like MAPbI3 is suitable compounds with good properties without segregation and good stability, the monovalent metal A is changed by an organic cation MA of equal charge. With the advantage that any organic cation can be used with the only condition that there is space to fit for avoiding the broke of three-dimensional (3D) network perovskite. At present, the cation that researched the best efficiency for perovskite solar cells are methylammonium (MA), rubidium $\mathrm{Rb}$, Cesium $\mathrm{Cs}$ and formamidinium (FA) and others like tetrabutylammonium (TBA), ethylammonium (EA) and guanidinium (GA) have been explored, representing appropriate materials for 3D perovskites with good properties.

The crystal properties for the layered structures turn out to be anisotropic with larger carrier masses and stronger exciton binding energies. for ABX3 the ideal cubic structure is taking place once the $\mathrm{B}-\mathrm{X}-\mathrm{B}$ angle is $180^{\circ}$, although quite a lot of changes can happen to the octahedral units specially 
that the connectivity can be influenced by the functionality between the cation and the metal and depends the size of the cation, leading to form in perovskite network three different connectivity : corner-sharing, face-sharing, or edge-sharing structure . Edge-sharing and Face-sharing structures leaded to non-perovskite lattices. However, the connectivity of the structural octahedral units can be formed various lattices: - a three-dimensional (3D) perovskite lattice is found once the connectivity is existing along all three axes - a two-dimensional (2D) perovskite network is obtained once the connectivity is missing in one axis. The general formula for $2 \mathrm{D}$ constituents can be A2MX4 or A+MX4. - a one-dimensional (1D) perovskite lattice is attained once the connectivity is missing in two axis. The general formula for materials can be A+MX5 or A3MX5. The flexibility of substitution in perovskite framework permits to contain cations such as $\mathrm{NH}+$, which can be considered spherical at normal temperatures. More complex phases, such as the inorganic-organic hybrid compounds $\mathrm{MAPbX3.} \mathrm{[38]}$

a

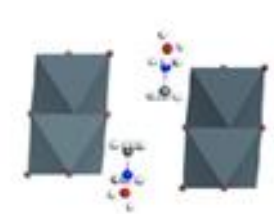

b Quantum Dots

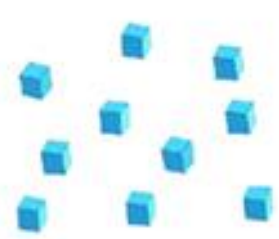

1D

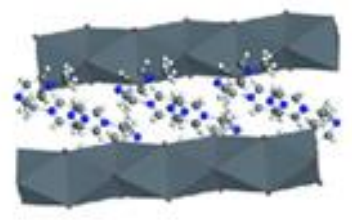

Nanowires

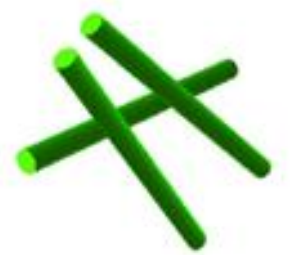

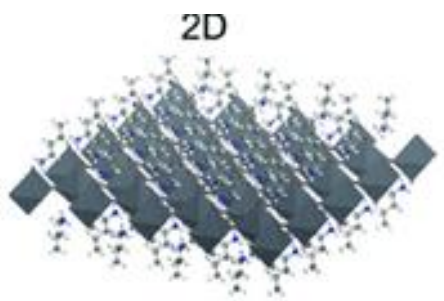

Nanoplatelets

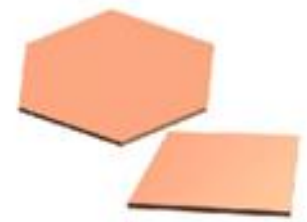

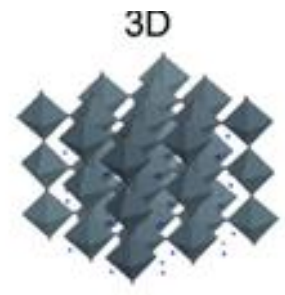

Thin Film

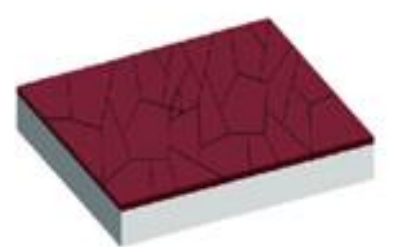

Figure 1.7. shows different perovskite networks structure: a three-dimensional (3D) perovskite - a two-dimensional (2D) perovskite. - a one-dimensional (1D) perovskite lattice

\subsection{Typical perovskite solar cells}

Photovoltaic cells named conventional, contain of the association of two semiconductors characterize by difference in electrical conductivity: A semiconductor n-type, the common charge carriers are electrons, and a semiconductor p-type deficient in electrons. The type of solar cells is classified on the photovoltaic over different method: the type of generation, trapping, charge recombination, and transport of electron-hole pairs during the semiconductor material and inside the contact electrodes. The light converts into electricity inside an n-p junction related directly to the 
electrical and optical properties of the two semiconductors materials of the n-p junction. Separately the semiconductor absorbs according to its energy gap, the adequate range of solar radiation.

In case of a solar cell based on perovskite materials, the perovskite film was used like an absorber in solar cells, and for the carrier transport material is likely to have a high conductivity with low surface recombination rate at the interface. Several materials have been used as carrier transport layers like: the zinc oxide $\mathrm{ZnO}$, titan dioxide $\mathrm{TiO} 2$ and PCBM as the electron transport layer (ETL) and as the hole transport layer (HTL) spiro-OMeTAD, nickel oxide $\mathrm{NiO}$, copper dioxide $\mathrm{CuO} 2$ or PEDOT: PSS (example figure 1.8) [39].
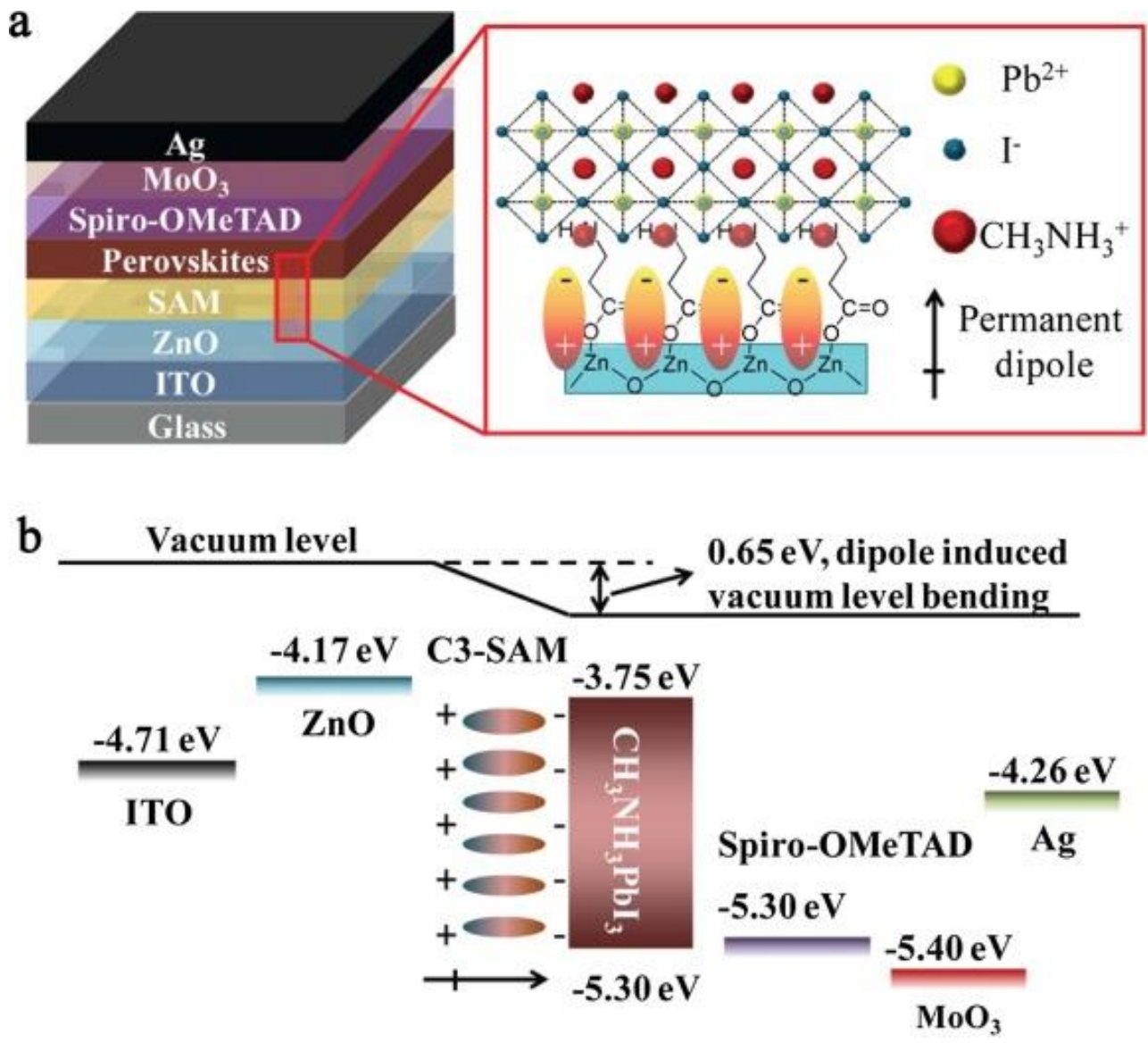

Figure 1.8 shows typical perovskite device been used as carrier transport layers like: the zinc oxide $\mathrm{ZnO}$, SAM as the electron transport layer (ETL) and as the hole transport layer (HTL) spiroOMeTAD.

Upon excitation by visible light, the charge carriers generated in perovskite material can be extracted by either transferring an electron to the $\mathrm{ZnO}$ layer or through hole transfer to the spiroOMeTAD hole transport layer [28]. Upon excitation by an incident photon (Figure 1.8) with energy 
equal to or greater than the band gap of the material, the photon is absorbed and excites an electron from the valence band into the conduction band of the material. Consequently, another electron from the valence band moves to the hole left by the first electron, this lead to a movement of the holes and the electrons. In case of a n-p junction, the carriers are separated by the internal electric field created by $n-p$ junction. The collection of carriers at the electrodes generates a potential difference and current in the external circuit, In this work, we will focus on the synthesis and the characterization of the $\mathrm{APbX} 3$ with $(\mathrm{A}=\mathrm{CH} 3 \mathrm{NH} 3, \mathrm{HC}(\mathrm{NH} 2) 2, \mathrm{Cs}$ and $\mathrm{X}=\mathrm{I}, \mathrm{Br}, \mathrm{cl})$. In particular, we will study the cubic and the tetragonal structure as shown in Figure 1.9.

(a)

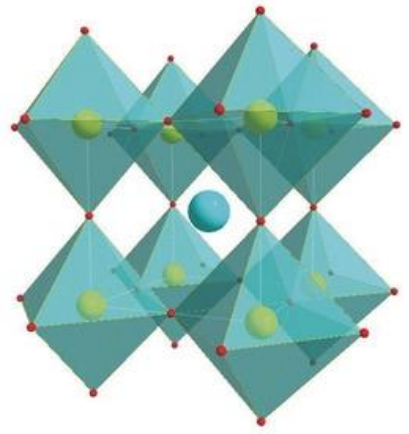

Cubic (b)

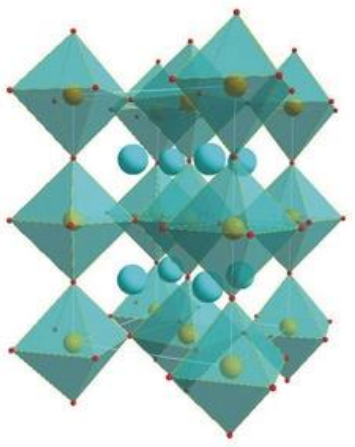

Tetragonal

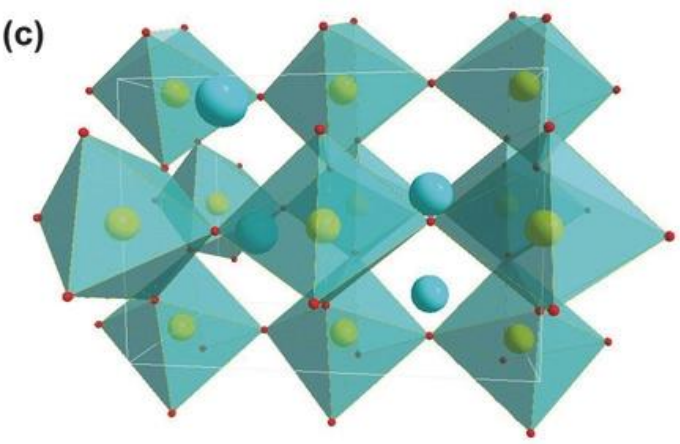

Orthorhombic
A site
B site
X site

Figure 1.9 Cubic (a) and tetragonal (b) structure of the $\mathrm{CH} 3 \mathrm{NH} 2 \mathrm{PbX} 3$ perovskite [29]

\subsection{Stability challenge}

Low stability is one of the worst inconvenient of the utilization of perovskite solar cells. Generally, the high performance of perovskite solar cells decreases their efficiencies, and show significantly degradation in short time from quite a lot of hours to some days. In order to become fully scalable, PSCs should meet at least stability standards of thin film photovoltaic cells (IEC 61646) in which only a $10 \%$ decrease from the initial performance is allowed over a period of $1000 \mathrm{~h}$ in accelerated aging tests (only 5\% is allowed for crystalline silicon solar cells). The solar cells efficiency $(\eta)$ normally calculated from the current-voltage (I-V) parameters, the short-circuit current density $\left(\mathrm{J}_{\mathrm{SC}}\right)$, the open-circuit voltage $\left(\mathrm{V}_{\mathrm{OC}}\right)$ and the fill factor $(\mathrm{FF})$. These parameters give direct information about degradation state of the solar cell, even if they do not offer the detailed information about degradation mechanisms. To investigate the degradation mechanisms in PSCs, some measurement techniques should be appliqued such as electrochemical impedance spectroscopy (EIS) technique, Quantum Efficiency technique, or IPCE (Incident Photon-to-electron Conversion Efficiency), expressed the conversion ratio of sun ray into electricity by a solar cell. So, Quantum 
Efficiency is an important indicator to estimate the performance of the device [30]. The EIS and IPCE techniques are generally accommodating to check which materials of the solar cell exposed to degradation, even if sometimes is difficult to differentiate the degrading components due to the juncture between the interfaces.

Additionally, to get sight into structural transformations and chemical changes, techniques such as SEM, TEM, PL, XRD, AFM and Raman are usually suitable to be used. Production methods of PSCs impact scientifically their high performance and long stability. However, many stability enhancements have been proceeding, due to the fast improvement in absorber compounds syntheses, device manufacture process and well understanding of the degradation mechanisms. In the investigation of stability of PSCs is divided into two categories: intrinsic and extrinsic. Intrinsic stability contains chemical and structural change in photovoltaic operating conditions (humidity, temperature and light exposure) with the existent of impurities, specifically oxygen molecule and water molecules, which are taking place in the device during manufacturing. Furthermore, extrinsic stability is related the failures of sealing and moisture blocking layers.

\section{Physics proprieties of solar cells:}

\subsection{Electronic properties of material}

As it is known that the electronic structure of the materials is completely different from conductors, to semiconductors and insulators as it is showed in Figure 1.10. for conductor's materials, the valence band $\left(\mathrm{V}_{\mathrm{B}}\right)$ overlap the conduction band $\left(\mathrm{C}_{\mathrm{B}}\right)$ and are able to move freely under the influence of an electric field. Electrons can be electrically or thermally excited, so the electrical

conductivity is above zero. In contrast, in semiconductors there are small band gaps of 0.5-3.0 eV between the full $V_{B}$ and the empty $C_{B}$. Neither filled nor empty bands contribute to the electrical conductivity of materials, because electrons cannot gain energy, since all energy levels are filled. The manner in which electrons jump from valence band to conduction band depends on the size of the band gap. 


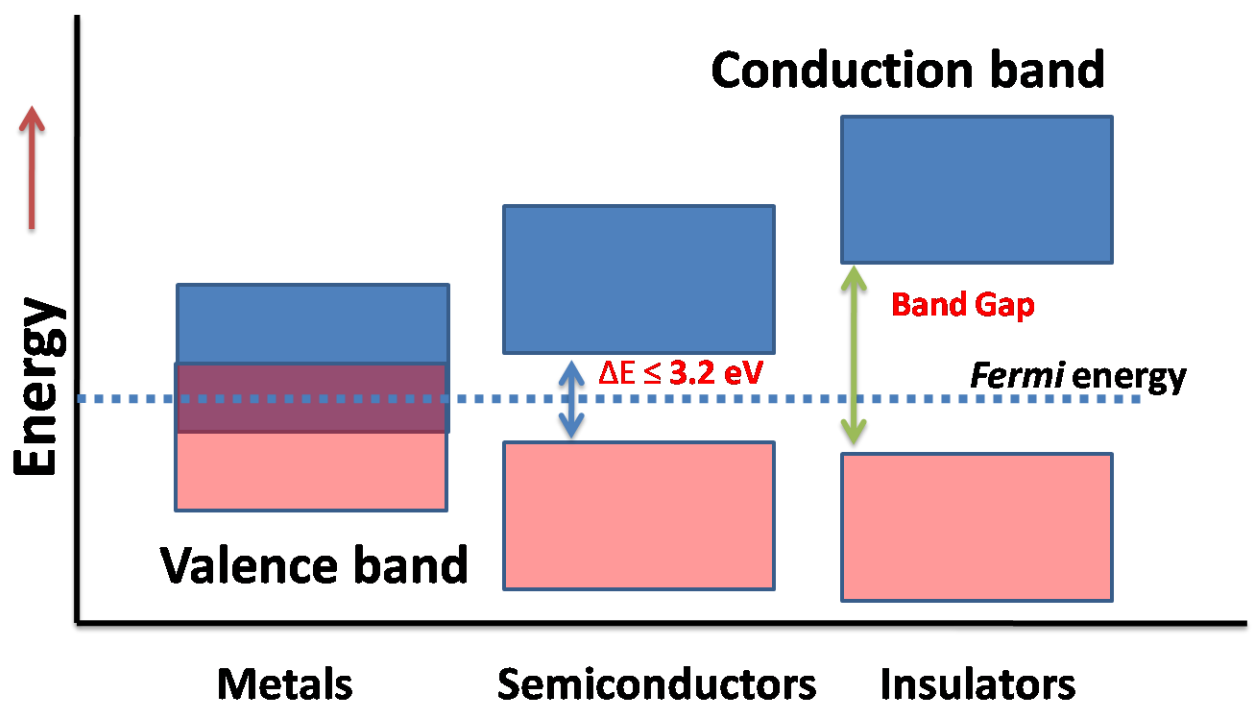

Figure 1.10: energy bands for conductors, semiconductor, and insulator.

When electrons are excited from valence band to conduction band a positively charged hole is left in valence band. If a hole in valence band is caused by impurities, the material is an extrinsic semiconductor (Figure 1.11).

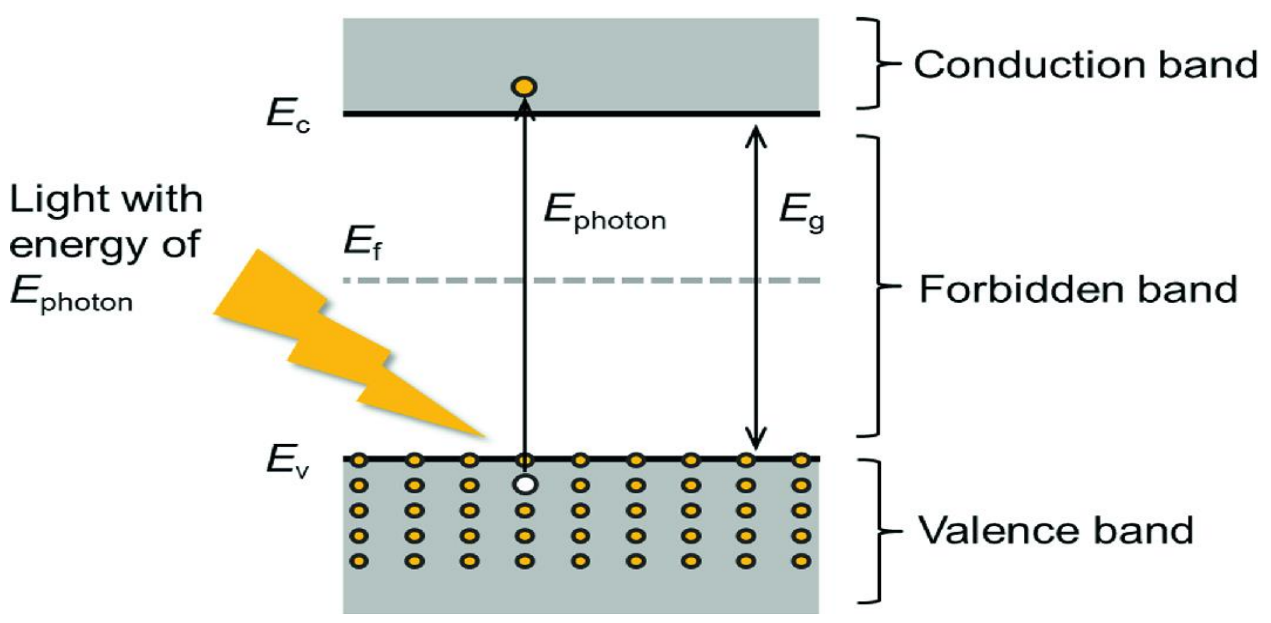

Figure 1.11 shows excited electrons from the valence band to conduction band in semiconductors materials

\subsection{Direct and indirect bandgap semiconductors}

For the determinization of the efficiency of absorption of light photons in a semiconductor absorber is known as the absorption coefficient. Once transitions of electrons from the valence band to the conduction band happen in semiconductors, a modification in crystal momentum $\mathrm{k}$ can or cannot happen. This occurrence of variation in $\mathrm{k}$, wave vector hangs on once the possible route accessible including lowest energy transition Figure 1.12. 


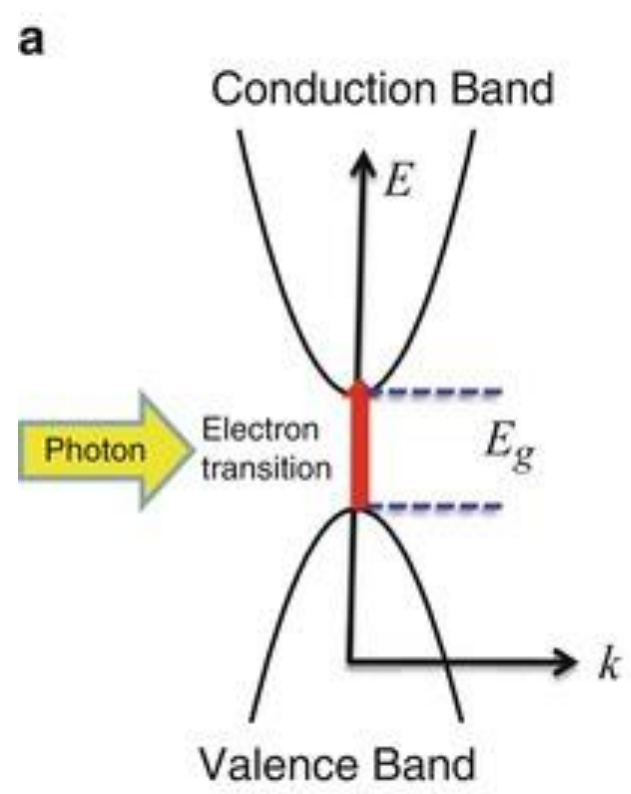

(a) Direct bandgap semiconductor (e. g. InAs and GaAs) b

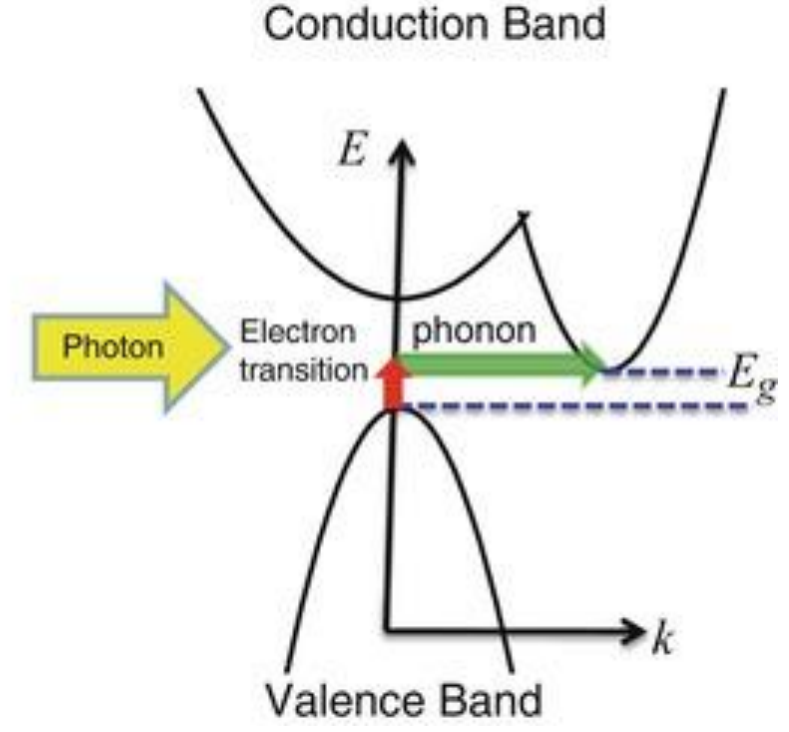

(b) Indirect bandgap semiconductor

(e. g. Ge and $\mathrm{Si}$ )

Figure 1.12 Energy band diagram for direct and indirect semiconductors.

\section{Thesis organization and Main points:}

The core objective of this research is to establish a new deposition procedure for the fabrication of high efficiency $\mathrm{Cu}(\mathrm{In}, \mathrm{Ga}) \mathrm{Se}_{2}$ thin film solar cells and Hybrid Organic-Inorganic Perovskites solar cell and realization of tandem perovskite/CIGS.

Chapter 2 introduces the techniques of elaboration used for elaboration of CIGS, CdS thin films and halide organic and inorganic thin film and the technique used for investigate the structural, Morphology, electrical and optical properties.

Chapters 3 present the investigation about the CIGS absorber film deposited by one step with optimization of the deposition parameters also we examined the effect of different back contact in structural and optical proprieties CIGS thin films. The structural behavior of the CIGS films was characterized by X-ray diffraction (XRD) the morphology of the deposited films was examined by scanning electron microscope (SEM), and transmission electron microscope (TEM). The topography of the samples was measured by atomic force microscopy (AFM). The optical properties were recorded in the wavelength from 400 to $950 \mathrm{~nm}$ by UV-Visible spectroscopy. Furthermore, the refractive index $(\mathrm{n})$, extinction coefficient $(\mathrm{k})$, real and imaginary parts of dielectric constant also estimated. 
Chapters 4 will focus about the growth of CIGS films by spray pyrolysis. The chapter is containing two part, first we will study the effect of experimental parameter and annealing process which is the key factor for Improving the performance of solar cells. In the second part, we will investigate the performance of solar cell CIGS, grown by the spray technique, by simulator scapes we get idea about the efficiency of solar cell.

Chapters 5 present the realization of the device $\mathrm{CdZnS/CdS/CIGS/Mo} \mathrm{with} \mathrm{The} \mathrm{main} \mathrm{target}$ to change the toxic $\mathrm{ZnO}$ by $\mathrm{CdZnS}$ with optimizing the amount of $\mathrm{Zn}$, which makes it easy to minimize the interface alignment and to illuminate the $\mathrm{p}-\mathrm{n}$ junction. The CdZnS/CdS/CIGS/Mo solar cell efficiency was measured and was characterized by the current-density voltage $(\mathrm{J}-\mathrm{V})$.

Chapters 6 present the effect of antisolvent diethyl ether t to improve the performance of $\mathrm{MAPbI}_{3}$ perovskite solar cells since the addition of diethyl ether greatly affects the crystalline process of $\mathrm{MAPbI}_{3}$ and causes an increase in the grains size of the perovskite thin film. The increase of the grain size may result increase in the light absorption of the perovskite layer if the use of diethyl ether is optimized, in our study, optimizing the addition of diethyl ether in perovskite-based solar cells based on $\mathrm{MAPbI}_{3}$ can very well increase the yield.

Chapter 7 introduces the Thin films perovskite Formamidinium lead triiodide $\mathrm{FAPbI}_{3}$ and doped Guanidinium (GA) $\mathrm{FA}_{1-\mathrm{x}} \mathrm{GA}_{\mathrm{x}} \mathrm{PbI}_{3}$ and the effect of GA substitution on structural, morphological and optical properties were investigated. The desirable $\alpha$-phase and undesirable $\delta$-phase of $\mathrm{FA}_{1-\mathrm{x}} \mathrm{GA}_{\mathrm{x}} \mathrm{PbI}_{3}$ thin films were studied after the incorporation of different GA content. in the formation of $\alpha / \delta$ phases and stabilization of the $\alpha-\mathrm{FaPbI}_{3}$ phase. Herein, the $10 \% \mathrm{GA}$ is an adequate amount for $\mathrm{FA}_{1-\mathrm{x}} \mathrm{GA}_{\mathrm{x}} \mathrm{PbI}_{3}$ lead to a homogenous, stable $\alpha$-phase, rough surface, large in grain size and free pinholes perovskite thin films. Furthermore, the stability was noticed.

Chapter 8 summarizes the work presented here and the overall and application of CIGS and $\mathrm{MAPbI}_{3}$ and $\mathrm{FAPbI}_{3}$ for tandem perovskite/CIGS.

\section{References:}

[1] Outlook, A. E. (2010). Energy information administration. Department of Energy, 92010(9), 115.

[2] Tuller, H. L. (2017). Solar to fuels conversion technologies: a perspective. Materials for renewable and sustainable energy, 6(1), 3 .. 
[3] Statistics, I. (2017). Key world energy statistics 2017. International Energy Agency.

[4] Forman, J. E., Timperley, C. M., Aas, P., Abdollahi, M., Alonso, I. P., Baulig, A., ... \& Gonzalez, D. (2018). Innovative technologies for chemical security. Pure and Applied Chemistry, 90(10), 15271557.

[5] Feurer, T., Reinhard, P., Avancini, E., Bissig, B., Löckinger, J., Fuchs, P., ... \& Buecheler, S. (2017). Progress in thin film CIGS photovoltaics-Research and development, manufacturing, and applications. Progress in Photovoltaics: Research and Applications, 25(7), 645-667.

[6] Green, M. A., Dunlop, E. D., Hohl-Ebinger, J., Yoshita, M., Kopidakis, N., \& Hao, X. (2020). Solar cell efficiency tables (version 56). Progress in Photovoltaics: Research and Applications, 28(7), 629-638.

[7] Feurer, T., Reinhard, P., Avancini, E., Bissig, B., Löckinger, J., Fuchs, P., ... \& Buecheler, S. (2017). Progress in thin film CIGS photovoltaics-Research and development, manufacturing, and applications. Progress in Photovoltaics: Research and Applications, 25(7), 645-667.

[8] Assadi, M. K., Bakhoda, S., Saidur, R., \& Hanaei, H. (2018). Recent progress in perovskite solar cells. Renewable and Sustainable Energy Reviews, 81, 2812-2822.

[9] Wang, F., Cao, Y., Chen, C., Chen, Q., Wu, X., Li, X., ... \& Huang, W. (2018). Materials toward the upscaling of perovskite solar cells: progress, challenges, and strategies. Advanced Functional Materials, 28(52), 1803753.

[10] Yamamoto, K., Yoshikawa, K., Uzu, H., \& Adachi, D. (2018). High-efficiency heterojunction crystalline Si solar cells. Japanese Journal of Applied Physics, 57(8S3), 08RB20.

[11] Hara, K., Ogawa, K., Okabayashi, Y., Matsuzaki, H., \& Masuda, A. (2017). Influence of surface structure of n-type single-crystalline Si solar cells on potential-induced degradation. Solar Energy Materials and Solar Cells, 166, 132-139.

[12] Dharmadasa, I. M. (2018). Advances in thin-film solar cells. CRC Press.

[13] Lee, T. D., \& Ebong, A. U. (2017). A review of thin film solar cell technologies and challenges. Renewable and Sustainable Energy Reviews, 70, 1286-1297.

[14] Rong, Y., Hu, Y., Mei, A., Tan, H., Saidaminov, M. I., Seok, S. I., ... \& Han, H. (2018). Challenges for commercializing perovskite solar cells. Science, 361(6408).

[15] Correa-Baena, J. P., Saliba, M., Buonassisi, T., Grätzel, M., Abate, A., Tress, W., \& Hagfeldt, A. (2017). Promises and challenges of perovskite solar cells. Science, 358(6364), 739-744. 
[16] Park, J. S., Kim, S., Xie, Z., \& Walsh, A. (2018). Point defect engineering in thin-film solar cells. Nature Reviews Materials, 3(7), 194-210.

[17] Lee, T. D., \& Ebong, A. U. (2017). A review of thin film solar cell technologies and challenges. Renewable and Sustainable Energy Reviews, 70, 1286-1297.

[18] Płaczek-Popko, E. (2017). Top PV market solar cells 2016. Opto-Electronics Review, 25(2), 5564.

[19] Mazzer, M., Rampino, S., Spaggiari, G., Annoni, F., Bersani, D., Bissoli, F., ... \& Pattini, F. (2017). Bifacial CIGS solar cells grown by low temperature pulsed electron deposition. Solar Energy Materials and Solar Cells, 166, 247-253.

[20] Ong, K. H., Agileswari, R., Maniscalco, B., Arnou, P., Kumar, C. C., Bowers, J. W., \& Marsadek, M. B. (2018). Review on substrate and molybdenum back contact in CIGS thin film solar cell. International Journal of Photoenergy, 2018.

[21] Regmi, G., Ashok, A., Chawla, P., Semalti, P., Velumani, S., Sharma, S. N., \& Castaneda, H. (2020). perspectives of chalcopyrite-based cigse thin-film solar cell: a review. journal of materials science-materials in electronics, 31(10), 7286-7314.

[22] Chantana, J., Kato, T., Sugimoto, H., \& Minemoto, T. (2017). Thin-film Cu (In, Ga)(Se, S) 2based solar cell with $(\mathrm{Cd}, \mathrm{Zn}) \mathrm{S}$ buffer layer and $\mathrm{Zn1-}$ xMgxO window layer. Progress in Photovoltaics: Research and Applications, 25(6), 431-440.

[23] Shaji, S., Vinayakumar, V., Krishnan, B., Johny, J., Kanakkillam, S. S., Herrera, J. F., ... \& Martinez, J. A. (2019). Copper antimony sulfide nanoparticles by pulsed laser ablation in liquid and their thin film for photovoltaic application. Applied Surface Science, 476, 94-106.

[24] Naghavi, N., Spiering, S., Powalla, M., Cavana, B., \& Lincot, D. (2003). High-efficiency copper indium gallium diselenide (CIGS) solar cells with indium sulfide buffer layers deposited by atomic layer chemical vapor deposition (ALCVD). Progress in Photovoltaics: Research and Applications, 11(7), 437-443.

[25] Liu, Y., Kong, D., Li, J., Zhao, C., Chen, C., \& Brugger, J. (2012). Preparation of Cu (In, Ga) Se2 thin film by solvothermal and spin-coating process. Energy Procedia, 16, 217-222.

[26] Jung, S., Ahn, S., Yun, J. H., Gwak, J., Kim, D., \& Yoon, K. (2010). Effects of Ga contents on properties of CIGS thin films and solar cells fabricated by co-evaporation technique. Current Applied Physics, 10(4), 990-996. 
[27] Wang, H., Zhang, Y., Kou, X. L., Cai, Y. A., Liu, W., Yu, T., ... \& Sun, Y. (2010). Effect of substrate temperature on the structural and electrical properties of CIGS films based on the one-stage co-evaporation process. Semiconductor science and technology, 25(5), 055007.

[28] Xu, C., Zhang, H., Parry, J., Perera, S., Long, G., \& Zeng, H. (2013). A single source three-stage evaporation approach to CIGS absorber layer for thin film solar cells. Solar energy materials and solar cells, 117, 357-362.

[29] Kaelin, M., Rudmann, D., Kurdesau, F., Zogg, H., Meyer, T., \& Tiwari, A. N. (2005). Low-cost CIGS solar cells by paste coating and selenization. Thin Solid Films, 480, 486-490.

[30] Bouich, A., Ullah, S., Ullah, H., Mari, B., Hartiti, B., Touhami, M. E., \& Santos, D. M. F. (2019).

Deposit on different back contacts: to high-quality CuInGaS 2 thin films for photovoltaic application. Journal of Materials Science: Materials in Electronics, 30(23), 20832-20839.

[31] Bouich, A., Hartiti, B., Ullah, S., Ullah, H., Touhami, M. E., Santos, D. M. F., \& Mari, B. (2019). Optoelectronic characterization of CuInGa (S) 2 thin films grown by spray pyrolysis for photovoltaic application. Applied Physics A, 125(8), 579.

[32] Bouich, A., Hartiti, B., Ullah, S., Ullah, H., Touhami, M. E., Santos, D. M. F., \& Mari, B. (2019). Experimental, theoretical, and numerical simulation of the performance of CuInxGa (1-x) S2-based solar cells. Optik, 183, 137-147.

[33] Aksu, S., Pethe, S., Kleiman-Shwarsctein, A., Kundu, S., \& Pinarbasi, M. (2012, June). Recent advances in electroplating based CIGS solar cell fabrication. In 2012 38th IEEE Photovoltaic Specialists Conference (pp. 003092-003097). IEEE.

[34] Romanyuk, Y. E., Hagendorfer, H., Stücheli, P., Fuchs, P., Uhl, A. R., Sutter-Fella, C. M., ... \& Grand, P. P. (2015). All Solution-Processed Chalcogenide Solar Cells-from Single Functional Layers Towards a 13.8\% Efficient CIGS Device. Advanced Functional Materials, 25(1), 12-27.

[35] Kaur, K., Kumar, N., \& Kumar, M. (2017). Strategic review of interface carrier recombination in earth abundant $\mathrm{Cu}-\mathrm{Zn}-\mathrm{Sn}-\mathrm{S}-\mathrm{Se}$ solar cells: current challenges and future prospects. Journal of Materials Chemistry A, 5(7), 3069-3090.

[36] Abou-Ras, D., Kostorz, G., Romeo, A., Rudmann, D., \& Tiwari, A. N. (2005). Structural and chemical investigations of CBD-and PVD-CdS buffer layers and interfaces in Cu (In, Ga) Se2-based thin film solar cells. Thin Solid Films, 480, 118-123.

[37] Ullah, S., Bouich, A., Ullah, H., Mari, B., \& Mollar, M. (2020). Comparative study of binary cadmium sulfide (CdS) and tin disulfide (SnS2) thin buffer layers. Solar Energy, 208, 637-642. 
[38] Yang, Y., Pham, N. D., Yao, D., Zhu, H., Yarlagadda, P., \& Wang, H. (2018). Inorganic p-type semiconductors and carbon materials based hole transport materials for perovskite solar cells. Chinese Chemical Letters, 29(8), 1242-1250.

[39] Shi, E., Gao, Y., Finkenauer, B. P., Coffey, A. H., \& Dou, L. (2018). Two-dimensional halide perovskite nanomaterials and heterostructures. Chemical Society Reviews, 47(16), 6046-6072.

[40] Leijtens, T., Eperon, G. E., Noel, N. K., Habisreutinger, S. N., Petrozza, A., \& Snaith, H. J. (2015). Stability of metal halide perovskite solar cells. Advanced Energy Materials, 5(20), 1500963. [41] Zhang, P., Wu, J., Zhang, T., Wang, Y., Liu, D., Chen, H., ... \& Li, S. (2018). Perovskite solar cells with ZnO electron-transporting materials. Advanced Materials, 30(3), 1703737.

[42] Liu, Y., Yang, Z., \& Liu, S. (2018). Recent Progress in Single-Crystalline Perovskite Research Including Crystal Preparation, Property Evaluation, and Applications. Advanced Science, 5(1), 1700471.

[43] Armin, A., Jansen-van Vuuren, R. D., Kopidakis, N., Burn, P. L., \& Meredith, P. (2015). Narrowband light detection via internal quantum efficiency manipulation of organic photodiodes. Nature communications, 6(1), 1-8.

[44] Alex Carrete, Marcel Placidi, Alexey Shavel, Alejandro Pérez-Rodríguez, and Andreu Cabot, Phys. Status Solidi A, 1-5 (2014) / DOI 10.1002/pssa.201431425 


\section{Chapter II:}

\section{Experimental procedures and \\ Characterization techniques of CIGS and Perovskite Solar cells}

\section{Contents}

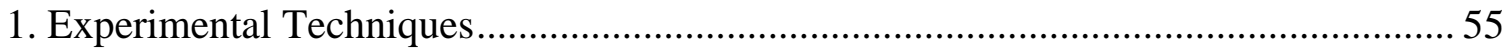

1.1. Electrochemical Deposition of the absorber CIGS thin films ................................ 55

1.2. Chemical Bath Deposition (CBD) for buffer layer CdS deposition:....................... 56

1.3. Elaboration of $\mathrm{ABX}_{3}$ perovskite thin films by Spin coating ................................. 57

1.4. Elaboration of CIGS thin films by spray pyrolysis:.............................................. 58

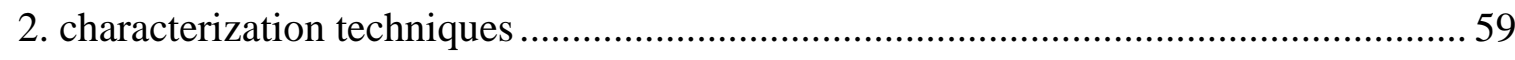

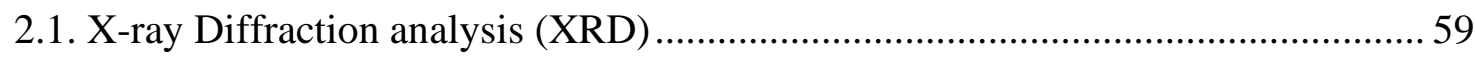

2.2. Field emission Scanning Electron Microscopy (FESEM) ....................................... 61

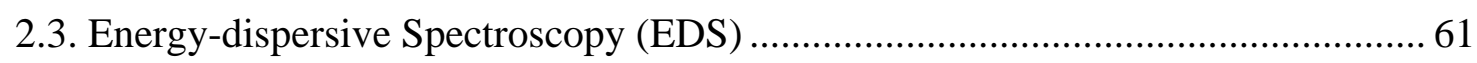

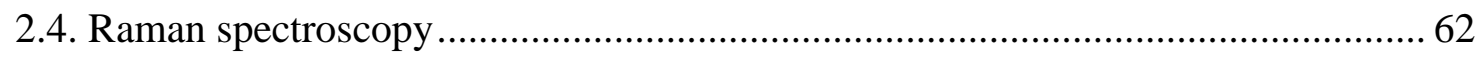

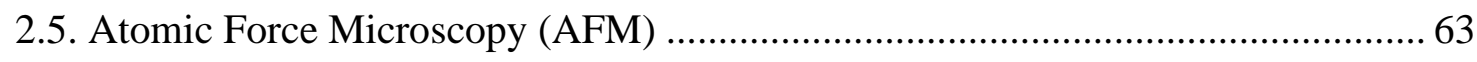

2.6. Transmission electron microscopy (TEM) analysis ................................................... 64

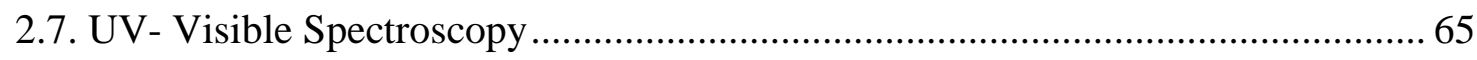

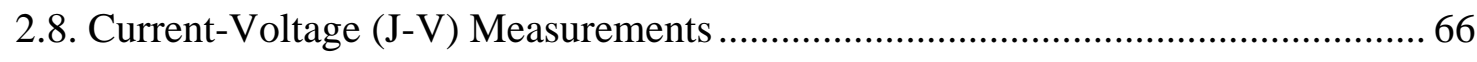




\section{Experimental Techniques}

\subsection{Electrochemical Deposition of the absorber CIGS thin films}

Electrodeposition is one manufacture technique of the thin film by good control of the electron flow, the film thickness deposited can be estimated by Faraday's Law of Electrolysis [1]. The electrolytic cell containing of three electrodes, an anode electrode, a cathode electrode, and an electrolyte include the metal ions. The main electroplating parameters consist of $\mathrm{Ph}$, concentration of element contains in electrolyte solution, complexing agent used, temperature of solution, current efficiency in solution, current density, current distribution, agitation [2][3].

Figure 2.1 shows a typical electrodeposition procedure contains the three types of electrode and electrolyte Counter Electrode (CE) that lets the current passing over the cell; the current flows between the Working Electrode WE and Counter Electrode CE. Reference Electrode (RE) that helps to keep a constant potential under the change of experimental parameters; the WE potential is referenced vs. the RE potential; REs are classically anodes in electrochemical cells; example: NHE. Working Electrode (WE) where the redox procedures; WEs are typically cathodes. Supporting Electrolyte is an ionic substance that exist in a solution to guarantee the conductivity in solution such as $\mathrm{KCl}$. The supporting electrolyte decreases the migration in the solution [4]. 


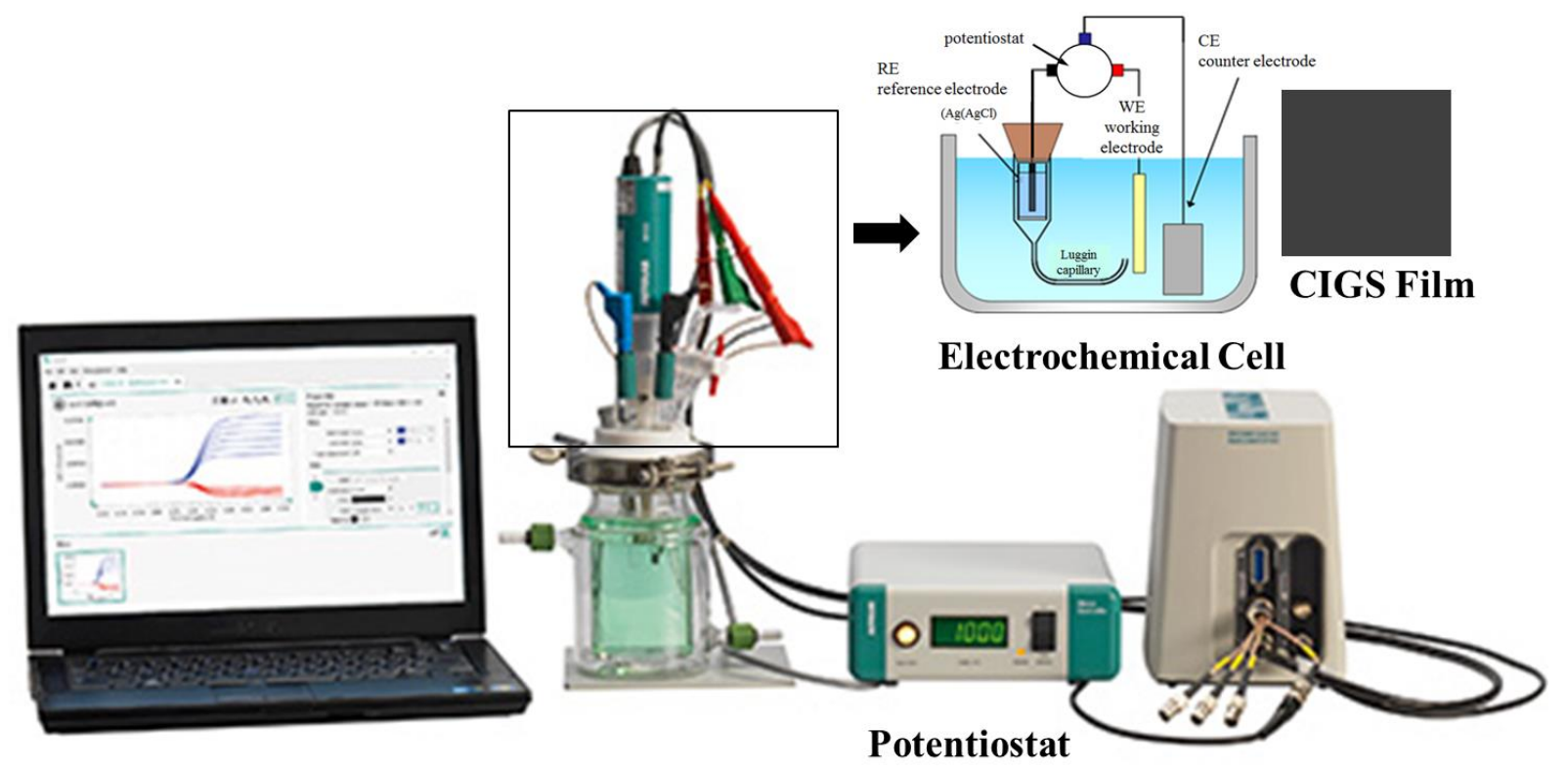

Figure 2.1 Schematic illustration of the electrochemical cells.

\subsection{Chemical Bath Deposition (CBD) for buffer layer CdS deposition:}

The Chemical Bath Deposition (CBD) technique is simple method, low temperature procedure, cheaper and large-area for the deposition of thin films (figure 2.2). This technique involves only solution contains the elements to deposit and glass substrate. Among several deposition methods, the CBD maintain stable production, adherent film with good reproducibility, uniform deposition. In this method, the layers can be grown on a substrate immersed in bath solution containing proper chemicals at range temperatures between $25^{\circ} \mathrm{C}$ and $100^{\circ} \mathrm{C}[5][6]$. 

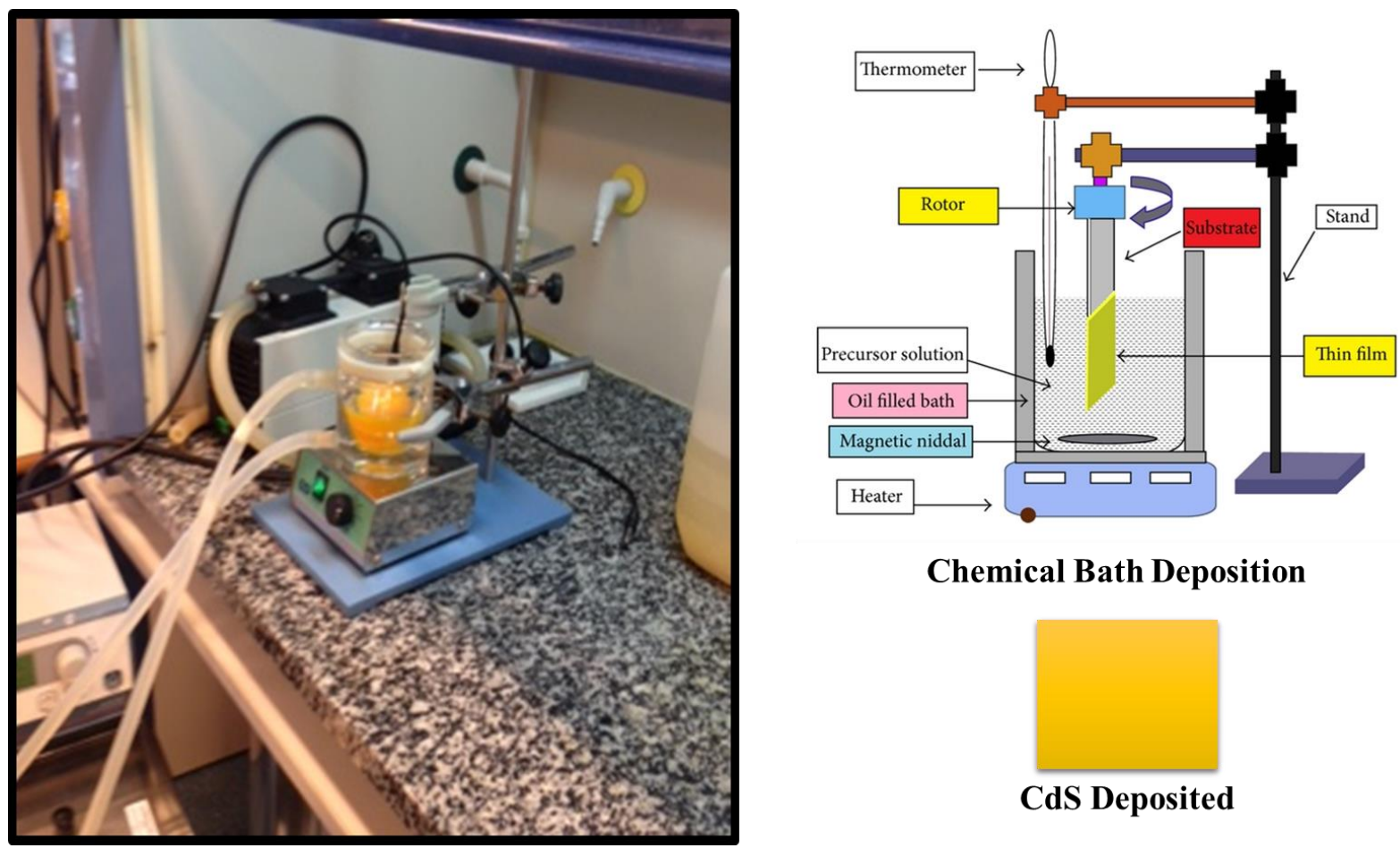

\section{Chemical Bath Deposition}

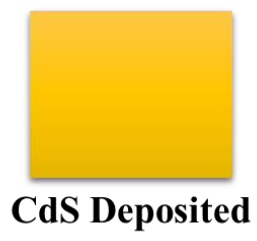

Figure 2.2: procedure of chemical bath deposition technique

\subsection{Elaboration of $A B X_{3}$ perovskite thin films by Spin coating}

Spin coating is a technique for uniform deposition thin films on smooth substrates, the machine used for this procedure is called a spin coater. Typically, on the substrate center, a small amount of the materials is applied and spinning at low speed as displays figure 2.3. Then the substrate is stated rotation up to $10,000 \mathrm{rpm}$ speed, the procedure ending by spread the coating material by centrifugal force. The solvent used is typically volatile and evaporates during the deposition process. The thickness of the film is related directly to the viscosity of the solvent and the composition of the solution [7]. One of main advantage of spin coating is create the formation of thin films with the uniform thickness [8]. 


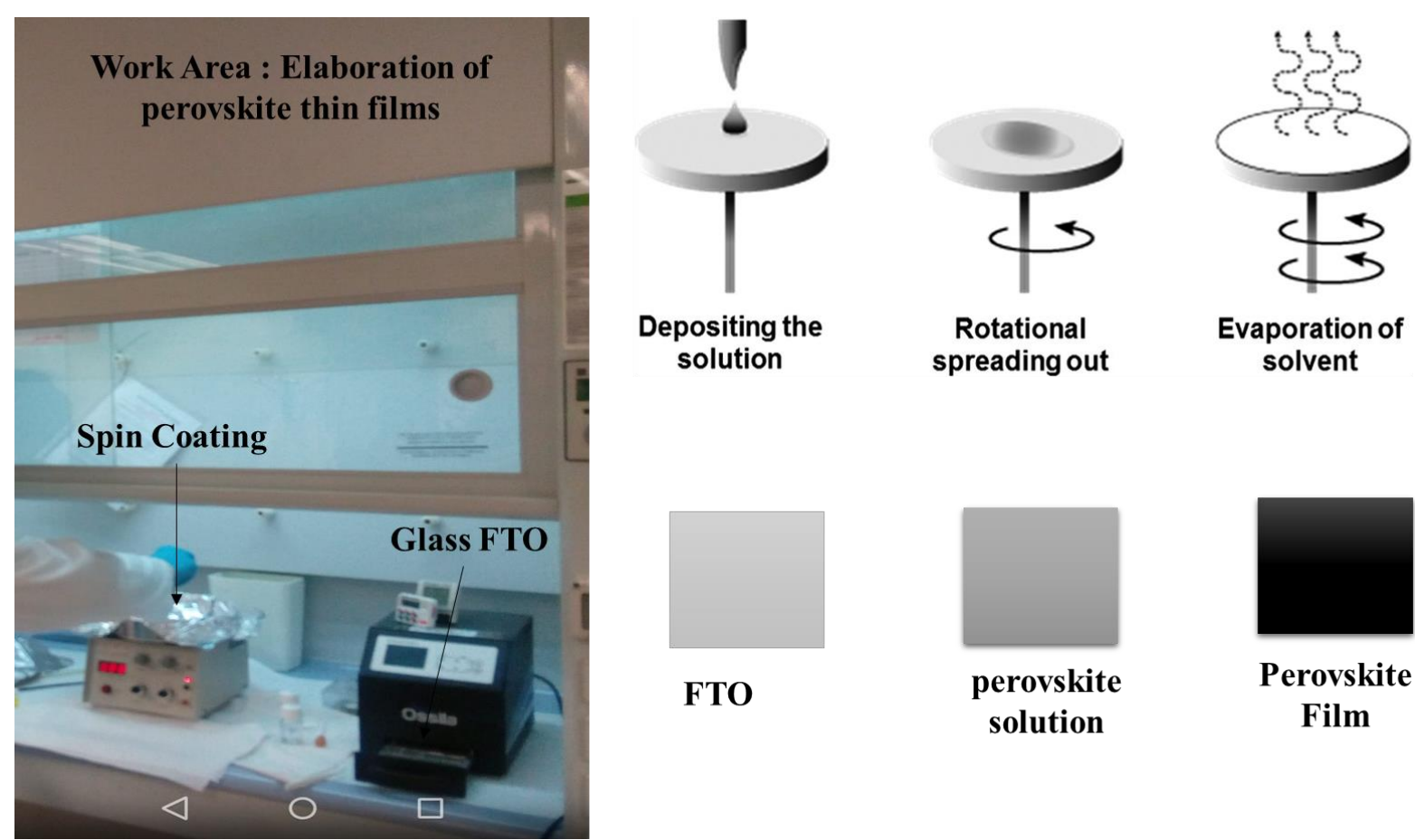

Figure 2.3 Schematic representation of spin coating technique.

\subsection{Elaboration of CIGS thin films by spray pyrolysis:}

Spray pyrolysis is simple and cheaper technique, the thin film is dropped by spraying the solution on heated substrate as illustrate figure 2.4 , where the materials react to form the desired compound. The deposition temperature is selected that the non-desired products can be evaporate. The technique is principally suitable for the deposition of oxide and has been a manufacture method for many absorbers to glass substrate [9][10]. 


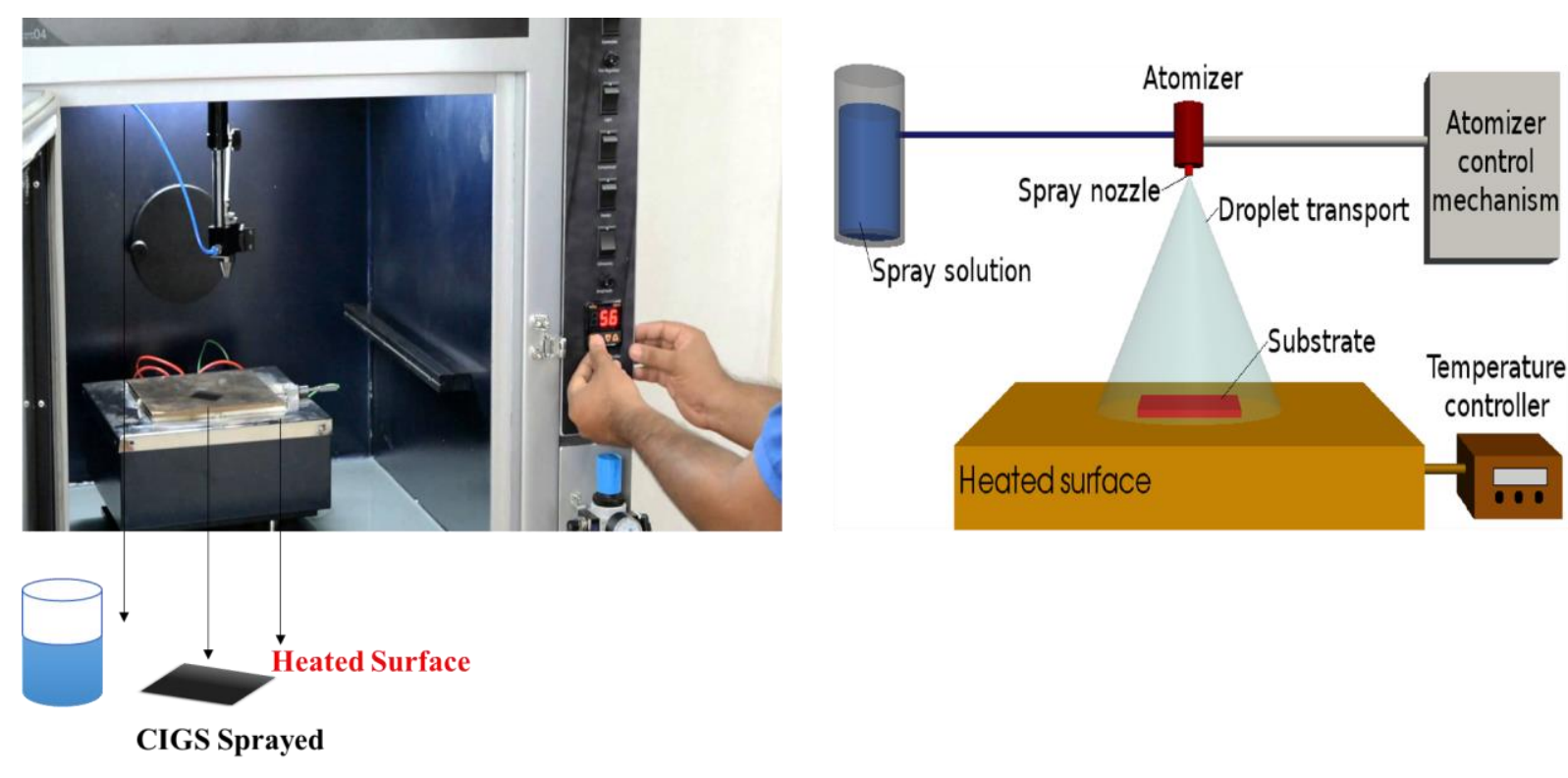

Figure 2.4 representation of Spray pyrolysis technique

\section{2. characterization techniques}

\subsection{X-ray Diffraction analysis (XRD)}

$\mathrm{X}$-ray diffraction is the most important technique to analyze the crystallinity of materials and to specify the structure. It is a crystallographic method used to characterize the different crystalline phases existing in materials samples [11][12]. 

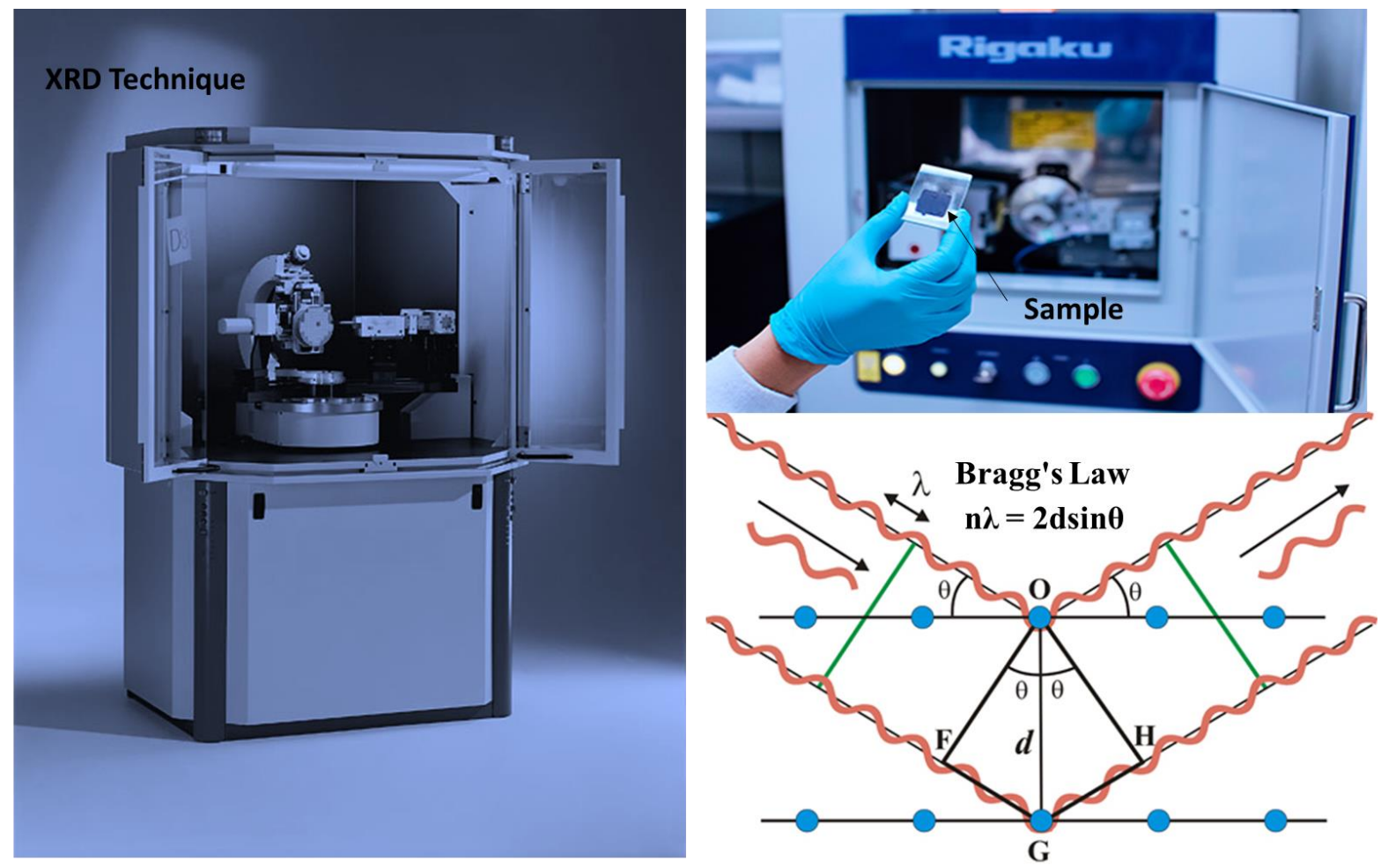

Figure 2.5 Image of X-ray diffraction technique and illustration of diffraction of X-rays

An X-ray beam is passed over a crystal and some of the $\mathrm{X}$ rays are scattered by the atom's electron, in the crystal or can be transmitted. When irradiating matter with a monochromatic X-ray beam at an angle of incidence, these X-rays are scattered (Rayleigh scattering) in all directions by everyone atoms of the target (Figure 2.5). They then interfere with each other. In some directions, these waves will cancel each other out and add up in others. When they cancel each other out, we talk destructive interferences while when they add up, we speak of interferences constructors. Constructive interference is materialized by the appearance of peaks of diffraction on the detector. This signal is only obtained if the scattered waves are in phase, we say while they diffract [13].

Bragg's Law is the formula as follows:

$$
\mathrm{n} \lambda=2 \mathrm{~d} \sin \theta
$$

Where $\mathrm{n}$ is order of reflection, $\lambda$ is the wavelength of the incident $\mathrm{X}$-rays, $\mathrm{d}$ is the inter planar spacing of the crystal and $\theta$ is the angle of incidence. The crystal atom is organized in a periodic way so the diffracted waves will comprise the sharp interference maxima (peaks) with the same symmetry as in the distribution of atoms. Calculating the diffraction pattern is giving the determination of the distribution of atoms in a crystal.

Also, From the X-ray diffraction can extracted structural parameters like crystal orientation, crystallite size that can be calculated by the Scherrer equation from the data of XRD pattern. 


$$
\mathrm{D}=\mathrm{K} \lambda / \mathrm{B} \cos \theta
$$

Where B $(2 \theta)$ is the line broadening at the full width half maximum (FWHM), K is the Scherrer constant which is around $0.9, \lambda$ is the incident X-ray wavelength and D is the crystallite size.

\subsection{Field emission Scanning Electron Microscopy (FESEM)}

Field emission scanning electron microscopy FESEM technique is used to exanimate structural and morphological surface of the sample at magnifications of $10 \mathrm{x}$ to $300,000 \mathrm{x}$. for providing information about the sample surface from the SEM, the sample is shouted by a beam of high or low electron energy contain in a field-emission cathode in the electron gun of a FESRM, if the beam has adequate energy, it excites an electron and eliminate from sample named by the secondary electron, or is dispersed named by the back-scattered electron. Both secondary and backscattered electrons are detected by their respective detectors as demonstrate figure 2.6.
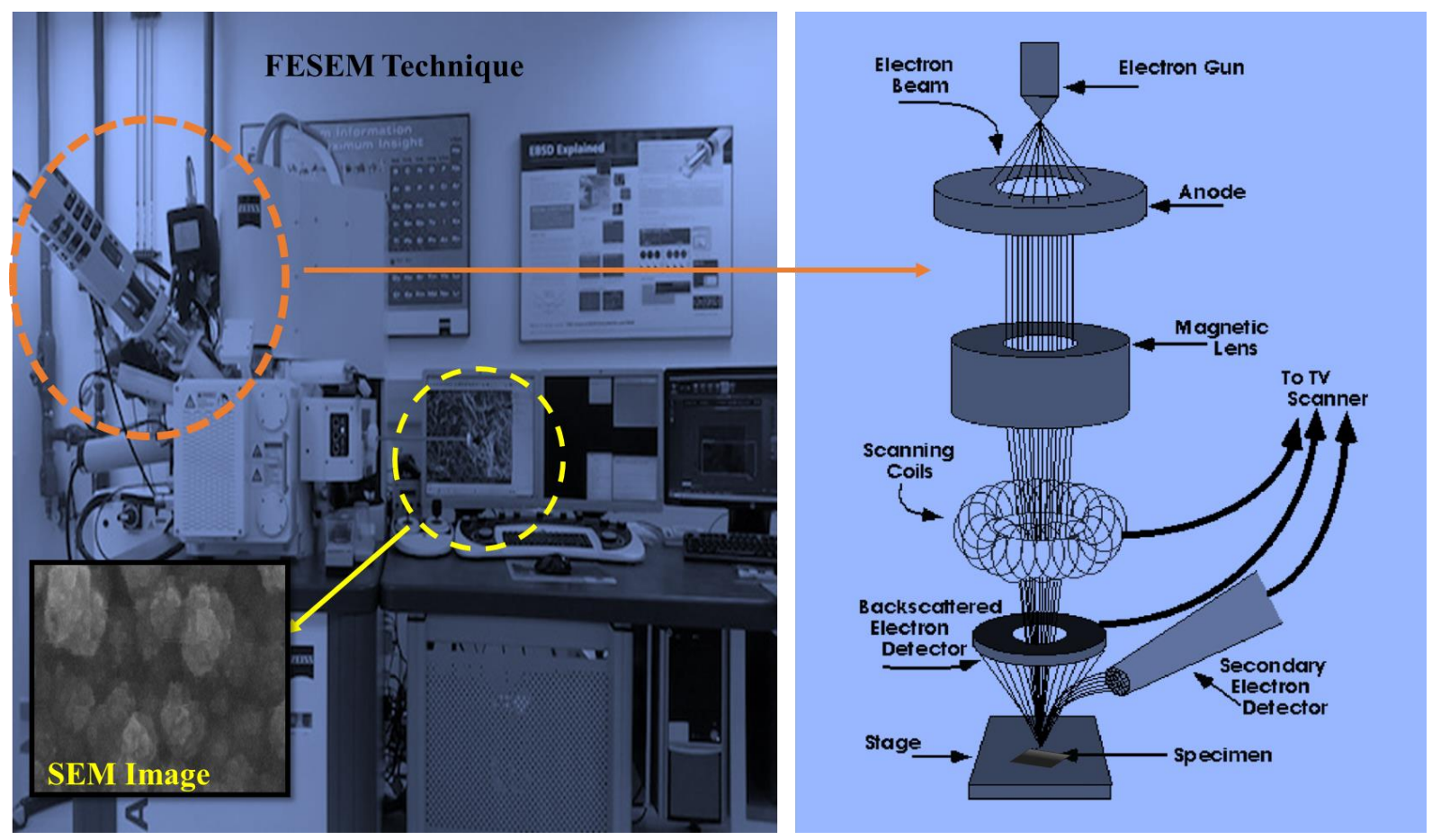

Figure 2.6 image of scanning electron microscopy (FESEM)

In our investigation, we used SEM type Zeiss ULTRA 55 Excel equipped with a $30 \mathrm{kV}$ field emission gun. SEM was performed on thin films deposited on molybdenum, FTO and ITO substrate,

\subsection{Energy-dispersive Spectroscopy (EDS)}

Energy-dispersive Spectroscopy (EDS) used for elemental and chemical analysis of sample. It depends of an interaction between the sample and X-ray excitation source. Precisely, The EDS 
detects x-rays emitted from the sample shooting by an electron beam to describe and explore the composition. In particular, Structures or phases less than $1 \mu \mathrm{m}$ can be perfectly examined. The time that the material is shelled by the beam, then electrons are ejected from the material's atoms. Further The vacancies created are occupied by other electrons from a higher state, in order to make equilibrium of the energy difference between electrons states, an x-ray is emitted. The x-ray energy is representing the characteristic element.

The EDS x-ray detector measures the relative abundance of emitted x-rays versus their energy. When an incident x-ray attacks the detector, it creates a charge pulse that is proportional to the energy of the x-ray. The charge pulse is converted to a voltage pulse (which remains proportional to the $\mathrm{x}$ ray energy) by a charge-sensitive preamplifier. The signal is then sent to a multichannel analyzer where the pulses are sorted by voltage. The energy, as determined from the voltage measurement, for each incident $\mathrm{x}$-ray is sent to a computer for display and further data evaluation. The spectrum of $\mathrm{x}$ ray energy versus counts is evaluated to determine the elemental composition of the sampled volume.

\subsection{Raman spectroscopy}

Raman spectroscopy is used to identify vibrational modes of materials, even rotational and low-frequency modes can be detected. It is normally used to offer a structural pattern serving to determine the molecules of structure. Raman spectroscopy relies upon inelastic scattering of photons using usually like source the monochromatic light, typically laser light used like source in the visible near infrared or near ultraviolet, the laser light interacts with molecule creating low or high shift of energy of the laser photons. The shift in energy provides information about the vibrational modes in the system.

Classically, laser beam send illumination to desired spot of the sample. then the collected Electromagnetic radiation coming from the sample is sent over a monochromator. Elastic scattered radiation at the wavelength referring to the laser light is filtered out, although the rest of the collected light is dispersed onto a detector as illustrate in Figure 2.7. 

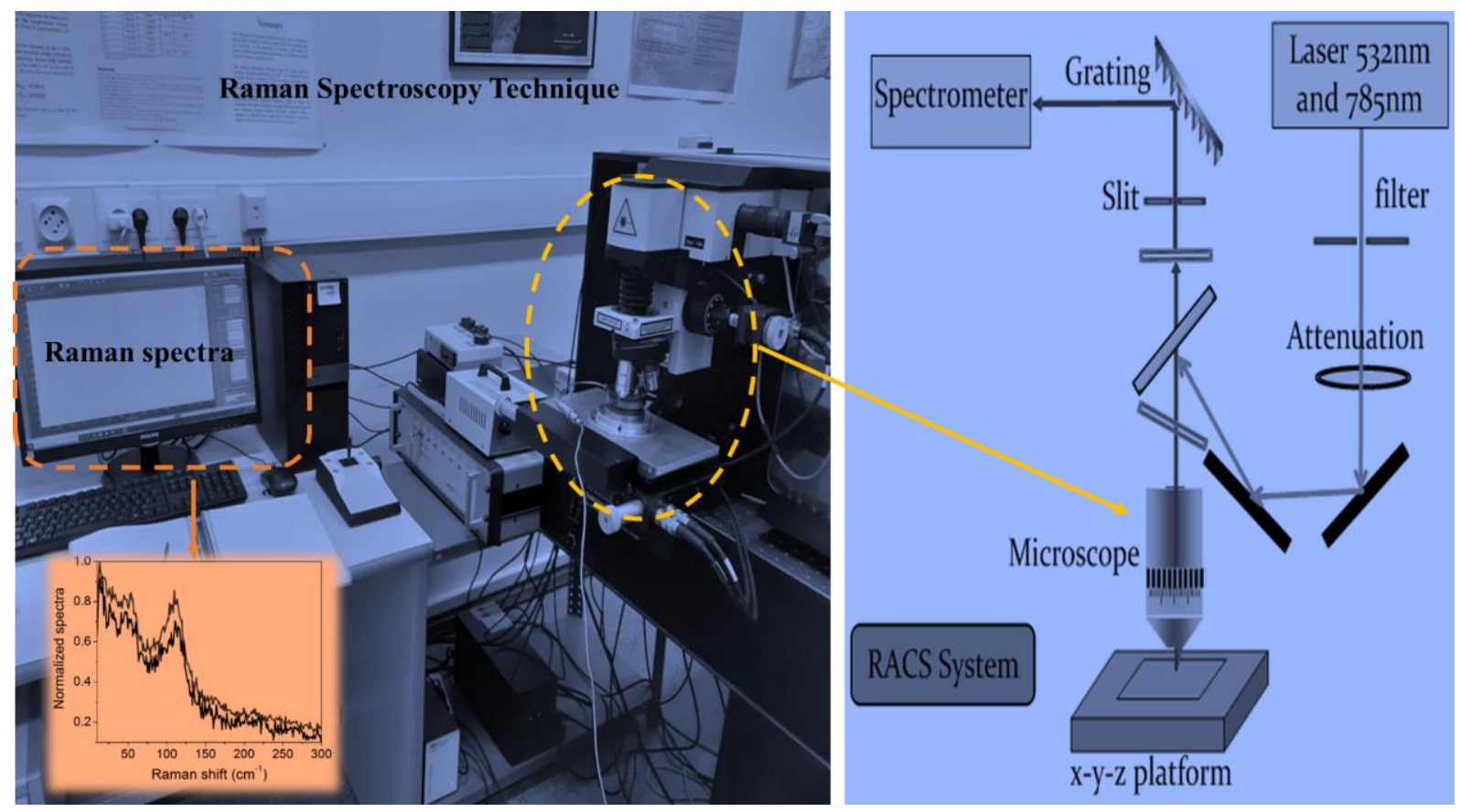

Figure 2.7 schema representation of Raman spectroscopy

\subsection{Atomic Force Microscopy (AFM)}

An atomic force microscope provides a 3D image of the surface with very-high-resolution on the order of fractions of a nanometer. consequently, very suitable in calculating the surface roughness. an AFM machine have a cantilever with a sharp tip and produces topographic images by running scan of small cantilever of material's surface as shown in figure 2.8, in other hand the sharp tip links to the surface, bending the cantilever and varying the amount of laser light reflected on the materials of the cantilever at the time of scanning. in some case the force on the cantilever caused deviation of the laser from his position, so a voltage is applied to make back laser to original position. the force on the cantilever is created due to the surface topographies on the sample. Due to the structural difference in sample, the cantilever deflects is calculated with a laser beam reflected. 


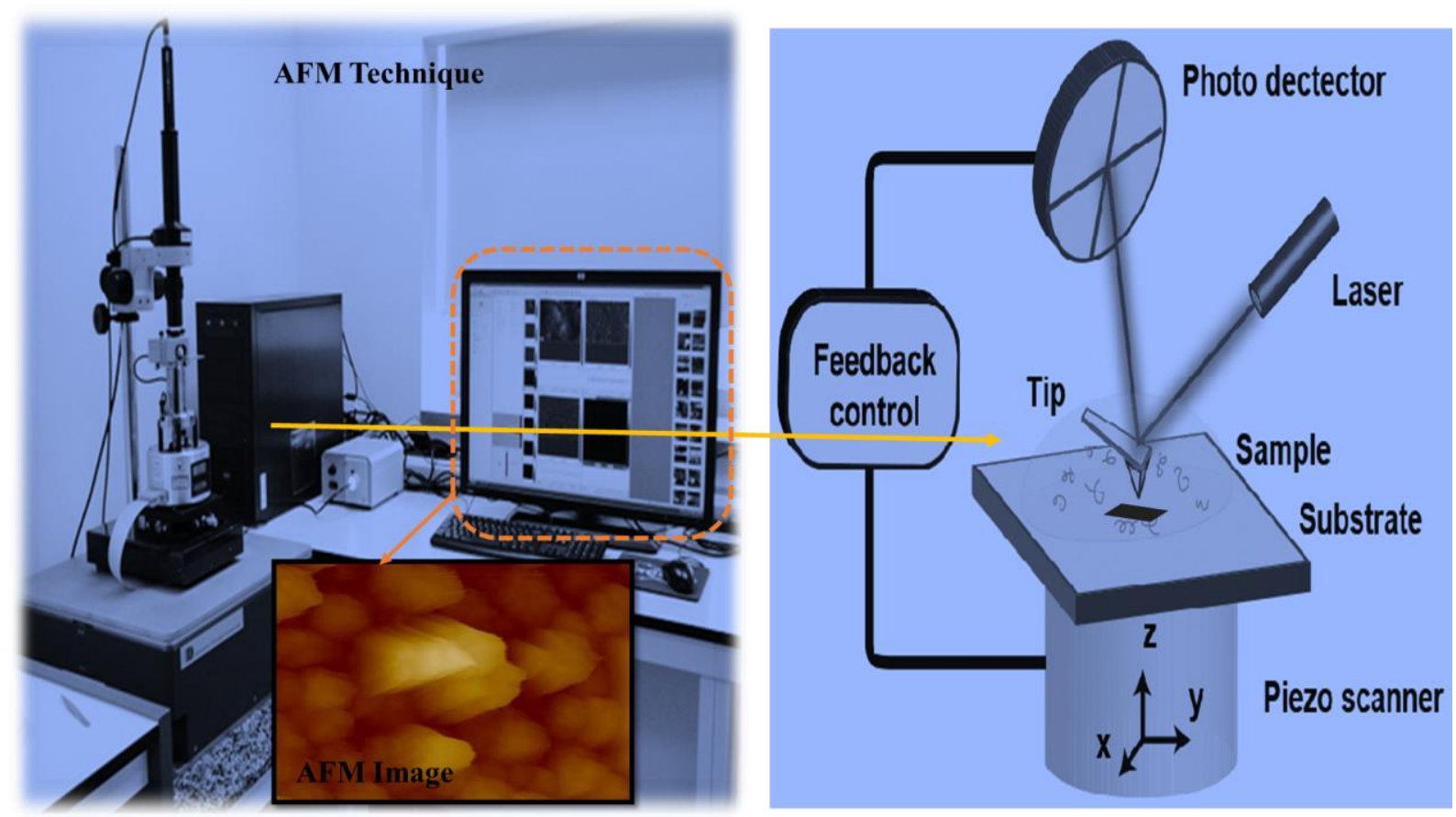

Figure 2.8 image of atomic force microscopy (AFM)

\subsection{Transmission electron microscopy (TEM) analysis}

For this characterization, the sample is a coverslip produced by a focused ion beam (FIB), extracted then observed in cross section by transmission electron microscopy (TEM). The high resolution of the TEM makes it possible to visualize, in image mode, the structures of sub-nanoscale dislocations. Figure 2.9 shows the TEM observations magnifications. 

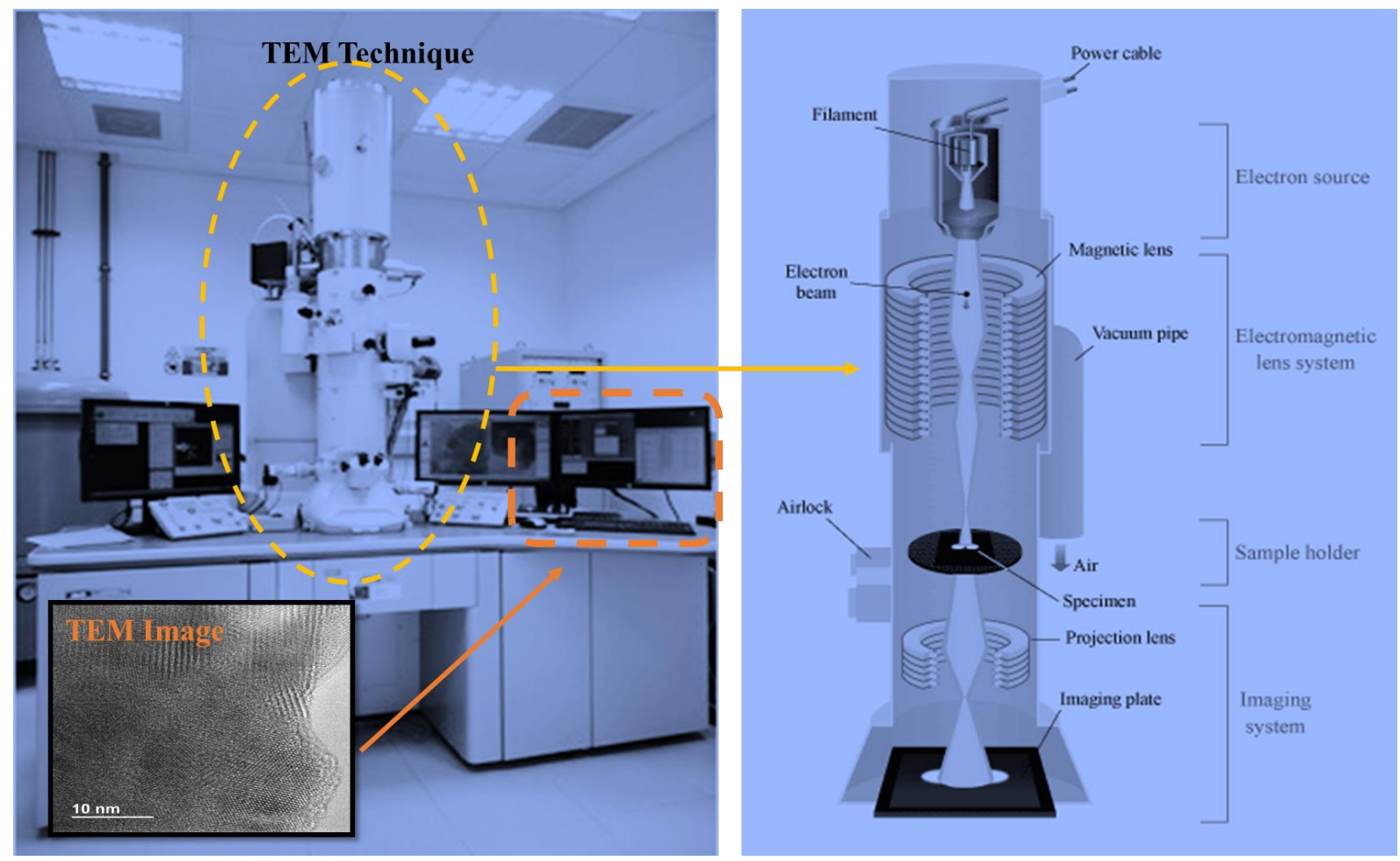

Figure 2.9 image of transmittance electron microscopy (TEM)

\subsection{UV- Visible Spectroscopy}

Spectrophotometry is a method of qualitative and quantitative analysis of a chemical substance based on the measurement of its absorbance (ability of a chemical substance to absorb or to diffuse light) when a light beam passes through it in a spectrophotometer. A beam of white light is made monochromatic through a prism or diffraction grating, that is, the light is broken down into different wavelengths. The beam is then directed to a sample that it passes through. Part of the light is then either absorbed by the sample and the other transmitted. We talk about absorption and transmission. The radiation transmitted light is collected by a detector as shown in the figure 2.10. 

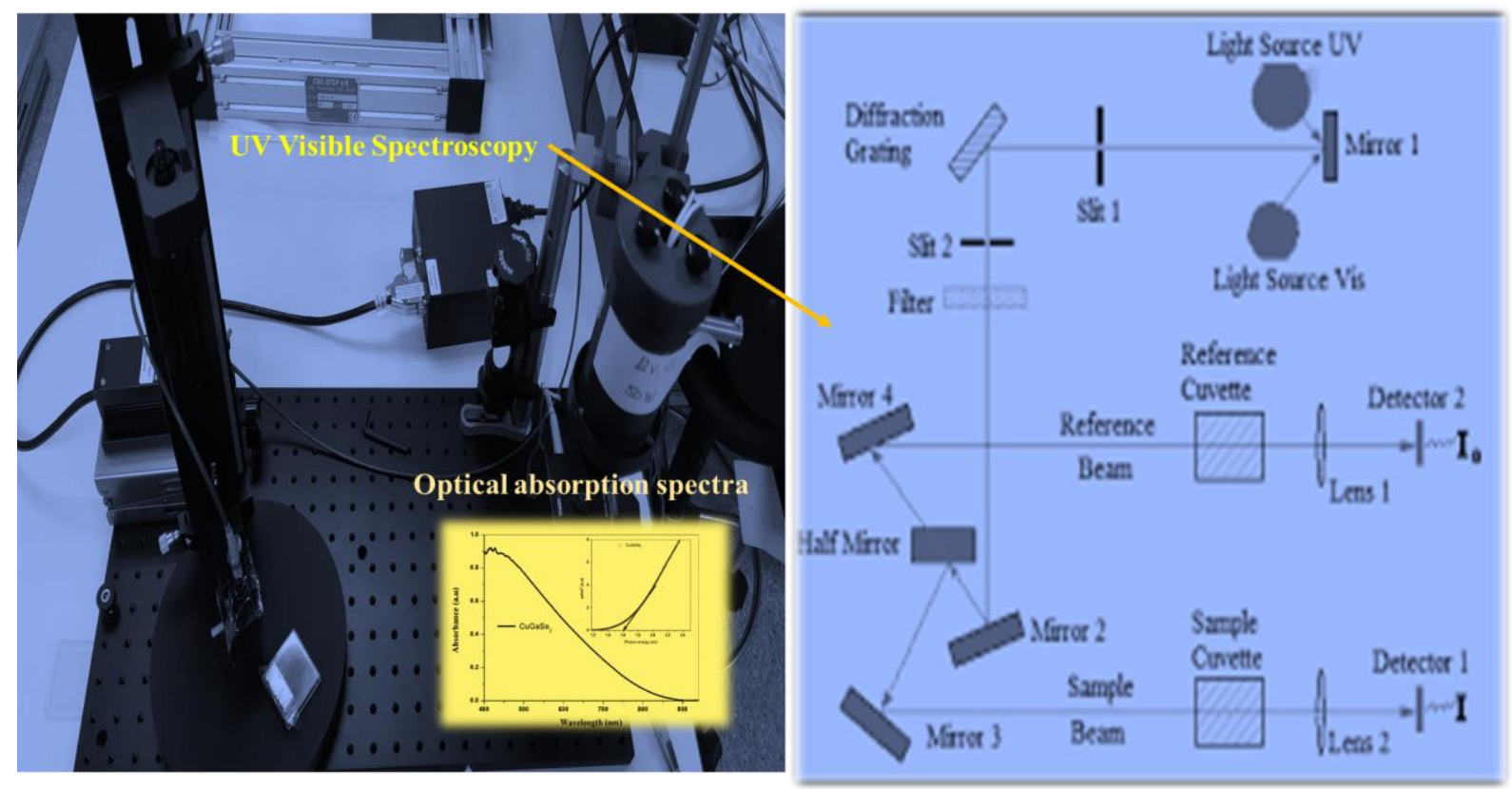

Figure 2.10 image of UV Visible spectroscopy

\subsection{Current-Voltage (J-V) Measurements}

The current-voltage characteristics were measured using a Keithley 236 multimeter. This multimeter is controlled by a computer under a LabView program, we allowing to choose the maximum and minimum values of the applied voltage, the number acquisition points for each voltage, the increment step. This program we also give access to the photovoltaic parameters ( $\mathrm{V}_{\mathrm{oc}}, \mathrm{J}_{\mathrm{sc}}, \mathrm{FF}, \mathrm{h}$, $\mathrm{R}_{\mathrm{s}}$ and $\mathrm{R}_{\mathrm{sh}}$ ) by a polynomial adjustment of measurement points (I, V).

The I-V characteristics are performed in the dark and under polychromatic illumination. For measurements under illumination, we have a solar simulator (Solar Constant $575 \mathrm{PV}$ ) fitted with a $575 \mathrm{~W}$ metal halide lamp. Spectrum of the lamp compared to the solar spectrum is shown in figure 3.9. The light power supplied by the lamp is measured by means of a Melles Griot power meter 13PEM001 


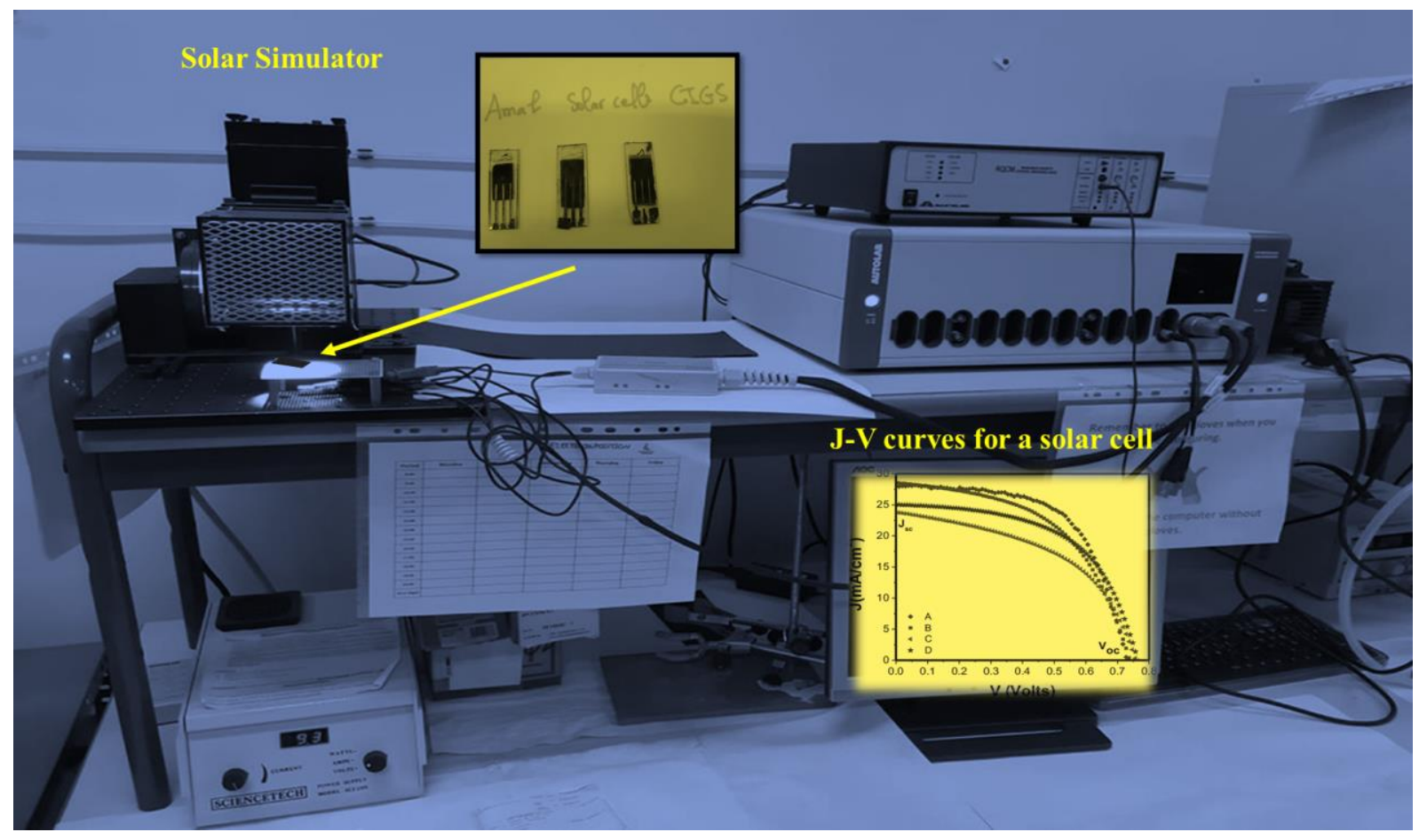

Figure 2.11. Example of $\mathrm{J}-\mathrm{V}$ curves for a solar cell in the dark and for the same solar cell under illumination.

\section{References:}

[1] Ghosh, S., Hawtof, R., Rumbach, P., Go, D. B., Akolkar, R., \& Sankaran, R. M. (2017). Quantitative study of electrochemical reduction of $\mathrm{Ag}+$ to $\mathrm{Ag}$ nanoparticles in aqueous solutions by a plasma cathode. Journal of The Electrochemical Society, 164(13), D818.

[2] Mandati, S., Sarada, B. V., Dey, S. R., \& Joshi, S. V. (2018). Pulsed Electrochemical Deposition of $\mathrm{CuInSe} 2$ and $\mathrm{Cu}$ (In, Ga) Se2 Semiconductor Thin-Films. Semiconductors-Growth and Characterization, 109-132.

[3] Miao, X., Chen, R., \& Cheng, W. (2017). Synthesis and characterization of Cu2FeSnS4 thin films prepared by electrochemical deposition. Materials Letters, 193, 183-186.

[4] Manivannan, R., \& Victoria, S. N. (2018). Preparation of chalcogenide thin films using electrodeposition method for solar cell applications-A review. Solar Energy, 173, 1144-1157.

[5] Kamal, T., Parvez, S., Matin, R., Bashar, M. S., Hossain, T., Sarwar, H., \& Rashid, M. J. (2016, October). Chemical Bath Deposition and Characterization of CdS layer for CZTS Thin Film Solar Cell. In Proceedings of International Exchange and Innovation Conference on Engineering \& Sciences (IEICES) (No. 2, p. 1). Interdisciplinary Graduate School of Engineering Sciences, Kyushu University. 
[6] Cho, J. Y., Sinha, S., Gang, M. G., \& Heo, J. (2019). Controlled thickness of a chemical-bathdeposited CdS buffer layer for a SnS thin film solar cell with more than $3 \%$ efficiency. Journal of Alloys and Compounds, 796, 160-166.

[7] Ho, J. S., Chang, S. C., Ho, J. J., Hsu, W. T., Chiang, C. C., Tsai, S. Y., ... \& Wang, K. L. (2017). Improving the performance of solar cells with novel buffer structure by the chemical bath deposition technique. Materials Science in Semiconductor Processing, 59, 29-34..

[8] Sharfuddin, M. (2016). Fabrication and characterization of ZNS buffer layer for thin film solar cell using chemical bath deposition (CBD) method (Doctoral dissertation, University of Dhaka).

[9] Kim, W., Park, J., Kim, H., Pak, Y., Lee, H., \& Jung, G. Y. (2017). Sequential dip-spin coating method: fully infiltration of MAPbI3-xClx into mesoporous $\mathrm{TiO} 2$ for stable hybrid perovskite solar cells. Electrochimica Acta, 245, 734-741.

[10] Song, D. H., Heo, J. H., Han, H. J., You, M. S., \& Im, S. H. (2016). Reproducible formation of uniform $\mathrm{CH} 3 \mathrm{NH} 3 \mathrm{PbI} 3-\mathrm{xClx}$ mixed halide perovskite film by separation of the powder formation and spin-coating process. Journal of Power Sources, 310, 130-136.

[11] Zheng, J., Zhang, M., Lau, C. F. J., Deng, X., Kim, J., Ma, Q., ... \& Ho-Baillie, A. W. (2017). Spin-coating free fabrication for highly efficient perovskite solar cells. Solar Energy Materials and Solar Cells, 168, 165-171.

[12] Babu, B. J., Egaas, B., \& Velumani, S. (2018). Selenization of CIS and CIGS layers deposited by chemical spray pyrolysis. Journal of Materials Science: Materials in Electronics, 29(18), 1536915375.

[13] Dhas, C. R., Christy, A. J., Venkatesh, R., Anuratha, K. S., Ravichandran, K., Raj, A. M. E., \& Panda, S. K. (2017). Nebulizer spray-deposited CuInGaS2 thin films, a viable candidate for counter electrode in dye-sensitized solar cells. Solar Energy, 157, 58-70.

[14] Faraj, M. G., Pakhuruddin, M. Z., \& Taboada, P. (2017). Effects of Substrate Temperature on Structural and Optical Properties of Spray-Pyrolyzed Cu (Ga 0.3 In 0.7) Se 2 Thin Films on Polyimide Plastic Substrate. Journal of Electronic Materials, 46(12), 6745-6749.

[15] Epp, J. (2016). X-ray diffraction (XRD) techniques for materials characterization. In Materials characterization using nondestructive evaluation (NDE) methods (pp. 81-124). Woodhead Publishing.

[16] Widjonarko, N. E. (2016). Introduction to advanced x-ray diffraction techniques for polymeric thin films. Coatings, 6(4), 54. 
[17] Hair Jr, J. F., Matthews, L. M., Matthews, R. L., \& Sarstedt, M. (2017). PLS-SEM or CB-SEM: updated guidelines on which method to use. International Journal of Multivariate Data Analysis, 1(2), 107-123.

[18] Smith, T. M., Bonacuse, P., Sosa, J., Kulis, M., \& Evans, L. (2018). A quantifiable and automated volume fraction characterization technique for secondary and tertiary $\gamma^{\prime}$ precipitates in Ni-based superalloys. Materials Characterization, 140, 86-94.

[19] Rokosz, K., Hryniewicz, T., Dudek, Ł., Matýsek, D., Valíček, J., \& Harničárová, M. (2016).

SEM and EDS analysis of surface layer formed on titanium after plasma electrolytic oxidation in H3PO4 with the addition of $\mathrm{Cu}$ (NO3) 2. Journal of Nanoscience and Nanotechnology, 16(8), 78147817.

[20] Verma, P. (2017). Tip-enhanced Raman spectroscopy: technique and recent advances. Chemical reviews, 117(9), 6447-6466.

[21] Malekpour, H., \& Balandin, A. A. (2018). Raman-based technique for measuring thermal conductivity of graphene and related materials. Journal of Raman Spectroscopy, 49(1), 106-120.

[22] Kwon, M. S., Kang, J. Y., Kim, S., Kim, J., \& Jeon, C. W. (2016). Application of slope-polishing technique for depth profile of selenized CIGS by micro-Raman spectroscopy. Applied Surface Science, 379, 186-190.

[23] Sigdel, K. P., Wilt, L. A., Marsh, B. P., Roberts, A. G., \& King, G. M. (2018). The conformation and dynamics of P-glycoprotein in a lipid bilayer investigated by atomic force microscopy. Biochemical pharmacology, 156, 302-311.

[24] Krieg, M., Fläschner, G., Alsteens, D., Gaub, B. M., Roos, W. H., Wuite, G. J., ... \& Müller, D. J. (2019). Atomic force microscopy-based mechanobiology. Nature Reviews Physics, 1(1), 41-57. [25] Dufrêne, Y. F., Ando, T., Garcia, R., Alsteens, D., Martinez-Martin, D., Engel, A., ... \& Müller, D. J. (2017). Imaging modes of atomic force microscopy for application in molecular and cell biology. Nature nanotechnology, 12(4), 295-307.

[26] Leijten, Z. J., Keizer, A. D., de With, G., \& Friedrich, H. (2017). Quantitative analysis of electron beam damage in organic thin films. The Journal of Physical Chemistry C, 121(19), 10552-10561.

[27] Fernández-Delgado, N., Herrera, M., Delgado, F. J., Tavabi, A. H., Luysberg, M., DuninBorkowski, R. E., ... \& Martínez-Pastor, J. P. (2019). Structural characterization of bulk and nanoparticle lead halide perovskite thin films by (S) TEM techniques. Nanotechnology, 30(13), 135701. 
[28] Pastor, J. V., García-Oliver, J. M., López, J. J., \& Micó, C. (2016). Application of UV-visible light absorption and scattering technique to low absorption fuels under diesel-like conditions. Fuel, 179, 258-266.

[29]Kurchin, R. C., Poindexter, J. R., Vähänissi, V., Savin, H., del Cañizo, C., \& Buonassisi, T. (2020). How Much Physics is in a Current-Voltage Curve? Inferring Defect Properties From Photovoltaic Device Measurements. IEEE Journal of Photovoltaics.

[30] Garris, R. L., Johnston, S., Li, J. V., Guthrey, H. L., Ramanathan, K., \& Mansfield, L. M. (2018). Electrical characterization and comparison of CIGS solar cells made with different structures and fabrication techniques. Solar Energy Materials and Solar Cells, 174, 77-83. 


\section{Chapter III:}

\section{Copper-indium-Gallium-Selenium (CIGS) thin films grown by electrochemical deposition for solar cells}

\section{Contents}

1. Investigation of CIGS and CIS grown by one-step electrodeposition technique ......... 72

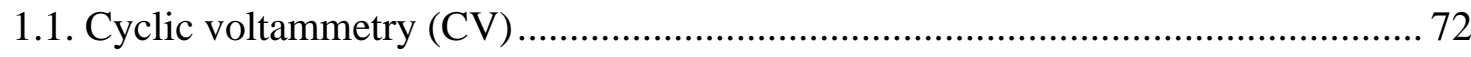

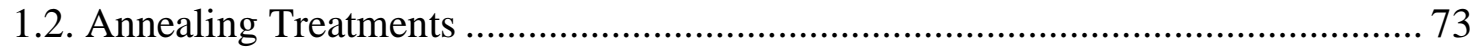

2. Deposit CuInGaS 2 thin film on different backs contacts ............................................. 73

2.1. $\mathrm{CuInGaS}_{2}$ thin film grown by one step electrodeposition: ...................................... 73

2.2. structural and morphology proprieties $\mathrm{CuInGaS}_{2}$ grown by one step electrodeposition

2.2.1. Structural measurements:.......................................................................... 74

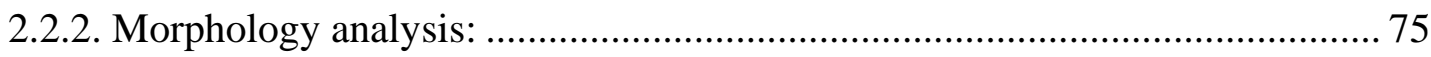

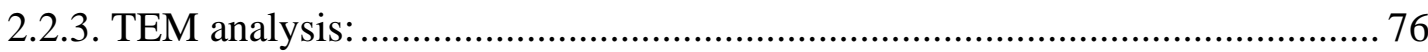

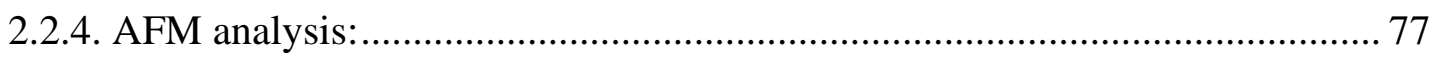

2.3. Optical proprieties $\mathrm{CuInGaS}_{2}$ grown by one step electrodeposition ...................... 78

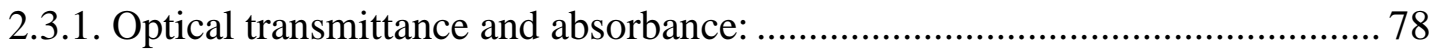

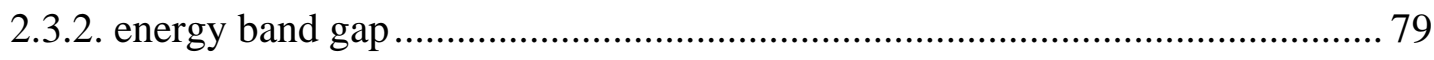

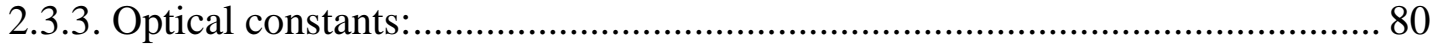

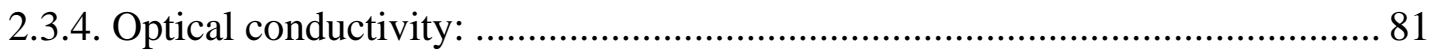


In this chapter the CIGS absorber film is deposited in one step to optimize the deposition parameters like deposition potential, deposition time and overvoltage of hydrogen on the surface of the deposited cathode also the parameters related to solution such us the concentrations of the precursors and the temperature of the bath and the $\mathrm{pH}$ of the solution also we investigate in details the impact of different back contact was in structural and optical proprieties CIGS thin films. The back contact has a significant effect for the fabrication of CIGS thin films for photovoltaic application. The structural behavior of the CIGS films was characterized by X-ray diffraction (XRD) the morphology of the deposited films was examined by scanning electron microscope (SEM), and transmission electron microscope (TEM). The topography of the samples was measured by atomic force microscopy (AFM). The optical properties were recorded in the wavelength from 400 to 950 $\mathrm{nm}$ by UV-Visible spectroscopy. Furthermore, the refractive index (n), extinction coefficient (k), real and imaginary parts of dielectric constant also estimated.

\section{Investigation of CIGS and CIS grown by one-step electrodeposition technique}

\subsection{Cyclic voltammetry (CV)}

Figure shows the $\mathrm{CV}$ at a scan rate of $100 \mathrm{mV} \mathrm{s}^{-1}$. The green curve defines the $\mathrm{CV}$ for the blank solution and display the peak at $-0.81 \mathrm{~V}$ characterizes the reduction of $\mathrm{H}^{+}$to $\mathrm{H}_{2}$. The red curve is representative the $\mathrm{CV}$ for $\mathrm{Cu}-\mathrm{Se}$ with reduction peak at $-0.69 \mathrm{~V}$ showed the formation of copper selenides.

The blue curve shows the $\mathrm{CV}$ of the former solution after addition of $\mathrm{Ga}^{3+}$. The addition of $\mathrm{Ga}^{3+}$ shifts the former peak from $-0.69 \mathrm{~V}$ until $-0.57 \mathrm{~V}(+0.12 \mathrm{~V})$ and it is attributed to $\mathrm{Ga}_{2} \mathrm{Se}_{3}$ (eq. 3.1). Then, the generated $\mathrm{Ga}_{2} \mathrm{Se}_{3}$ is assimilated into copper selenides as shown in figure 3.1 and, according to reaction, is rapidly transformed into copper gallium diselenide (eq. 3.2).

$$
\begin{gathered}
3 \mathrm{H}_{2} \mathrm{Se}+2 \mathrm{Ga}^{3+} \leftarrow \rightarrow \mathrm{Ga}_{2} \mathrm{Se}_{3}+6 \mathrm{H}^{+} \\
\mathrm{Cu}_{2} \mathrm{Se}+\mathrm{Ga}_{2} \mathrm{Se}_{3} \leftarrow \rightarrow 2 \mathrm{CuGaSe}_{2}
\end{gathered}
$$



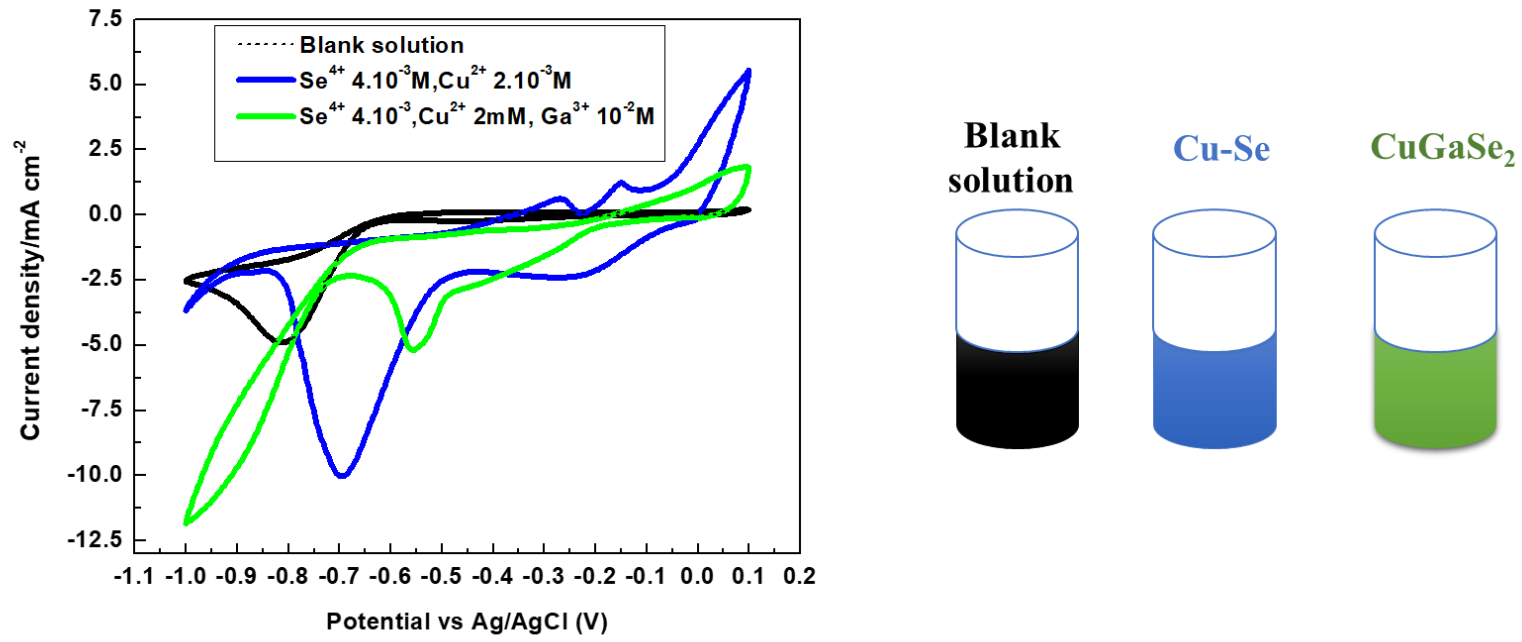

Figure 3.1 Cyclic Voltammograms of a Mo-coated electrode in three precursor electrolytes: blank solution (Black line), (Blue line) and (Green line).

\subsection{Annealing Treatments}

To get insight about the effect of annealing on structural and optoelectronic properties of the thin films. Figure shows the post deposition process with two different lines one is red and other is black, the black one displays the required temperature and the red one the maximum temperature, $\mathrm{t} 2$ denote the time we need to reached up to the required temperature which is around $450{ }^{\circ} \mathrm{C}$, then $\mathrm{t} 3$ is the time where temperature keeps constant for 40 minutes and $t 4$ is the down fall temperature time as indicated in Figure 3.2.
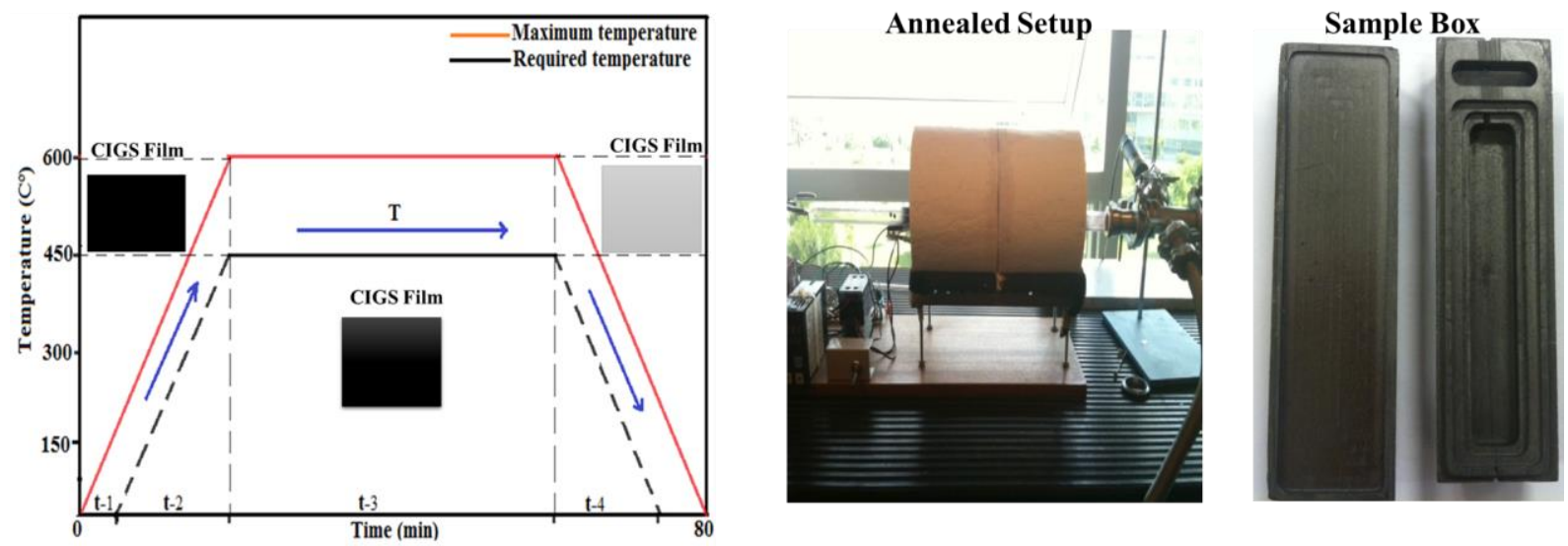

Figure 3.2 Schematic illustration of a typical temperature profile for the post annealing treatment.

\section{Deposit $\mathrm{CuInGaS} \mathbf{S}_{2}$ thin film on different backs contacts}

\subsection{CuInGaS 2 thin film grown by one step electrodeposition:}


The CIGS thin films were prepared by electrodeposition technique by one step deposition, for the working electrode three types of different back contacts have been used, fluorine tin oxide (ITO), Fluorine doped Tin Oxide (FTO) and Molybdenum Mo with their Specifications in Table 3.1.

The electrolyte consisted of a $40 \mathrm{ml}$ solution $0.005 \mathrm{M} \mathrm{CuCl}_{2}, 0.05 \mathrm{M} \mathrm{InCl}_{3}, 0.03 \mathrm{M} \mathrm{GaCl}_{3}, 0.025$ $\mathrm{M} \mathrm{H}_{2} \mathrm{SeO}_{3}$ and $0.1 \mathrm{M} \mathrm{LiCl}$ was used as a complexing agent. The $\mathrm{pH}$ was adjusted to be 2.2 by adding drop wise concentrated $\mathrm{HCl}$ [12]. For the electrodeposition an external potential source was used with applied voltage at the range of $-0.6 \mathrm{~V}-0.9 \mathrm{~V}$ at room temperature during the deposition process. The as deposited films ware cleaned by distilled water to remove the lose bonded ions and subsequently annealed at $500{ }^{\circ} \mathrm{C}$ for 40 minutes.

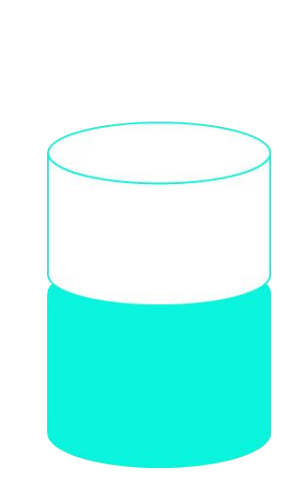

The electrolyte of Cu-In-Gu-Se
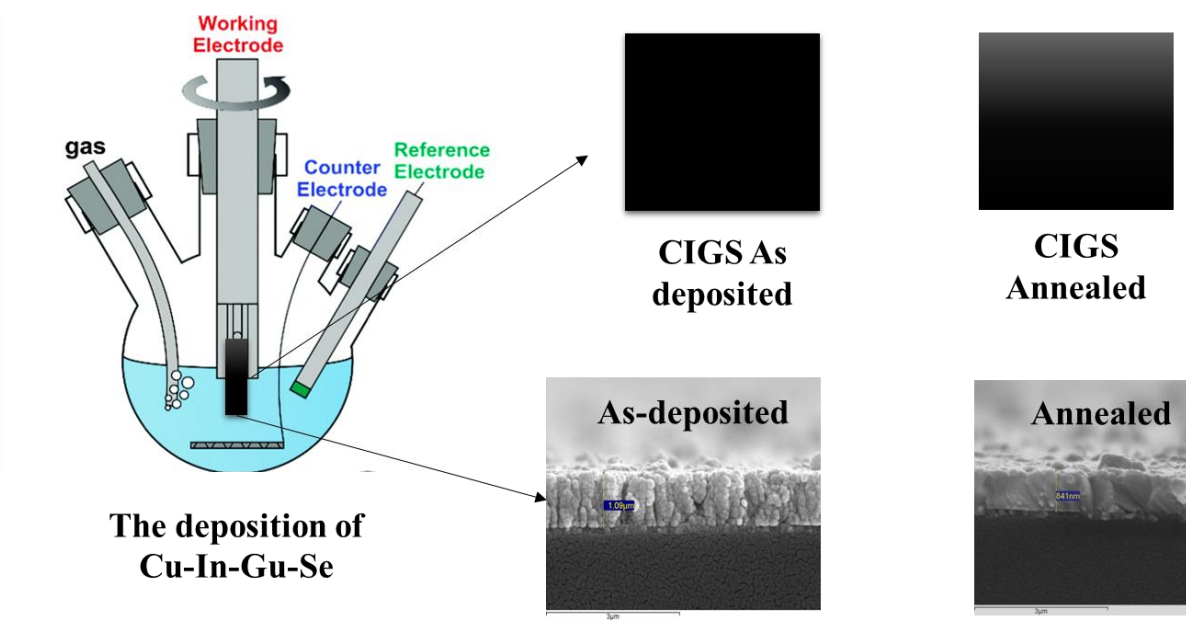

Figure 3.3: procedure of CIGS thin film deposited in different back contact with Electrodeposition

Table 3. 1: Specifications of different back contact.

\begin{tabular}{|c|c|c|c|}
\hline Glass plates & FTO & ITO & MO \\
\hline Resistivity $(\Omega / s q)$ & $7-10$ & $9-15$ & 0.60 \\
\hline Thickness (nm) & 250 & 180 & 500 \\
\hline
\end{tabular}

\section{2. structural and morphology proprieties $\mathrm{CuInGaS}_{2}$ grown by one step electrodeposition}

\subsubsection{Structural measurements:}

Figure 3.3 displays the (112), (220), and (312) peaks matching with CIGS chalcopyrite through tetragonal crystallography structure as verified by JCPDS diffraction file No. 35-1102.

For the three different back contacts is shown that the characteristic peak intensity (112) of the CIGS thin film with significant change of the intensity from lower intensity in case of ITO and FTO as back contact to higher intensity around double for Mo back contact $[1,3]$. 

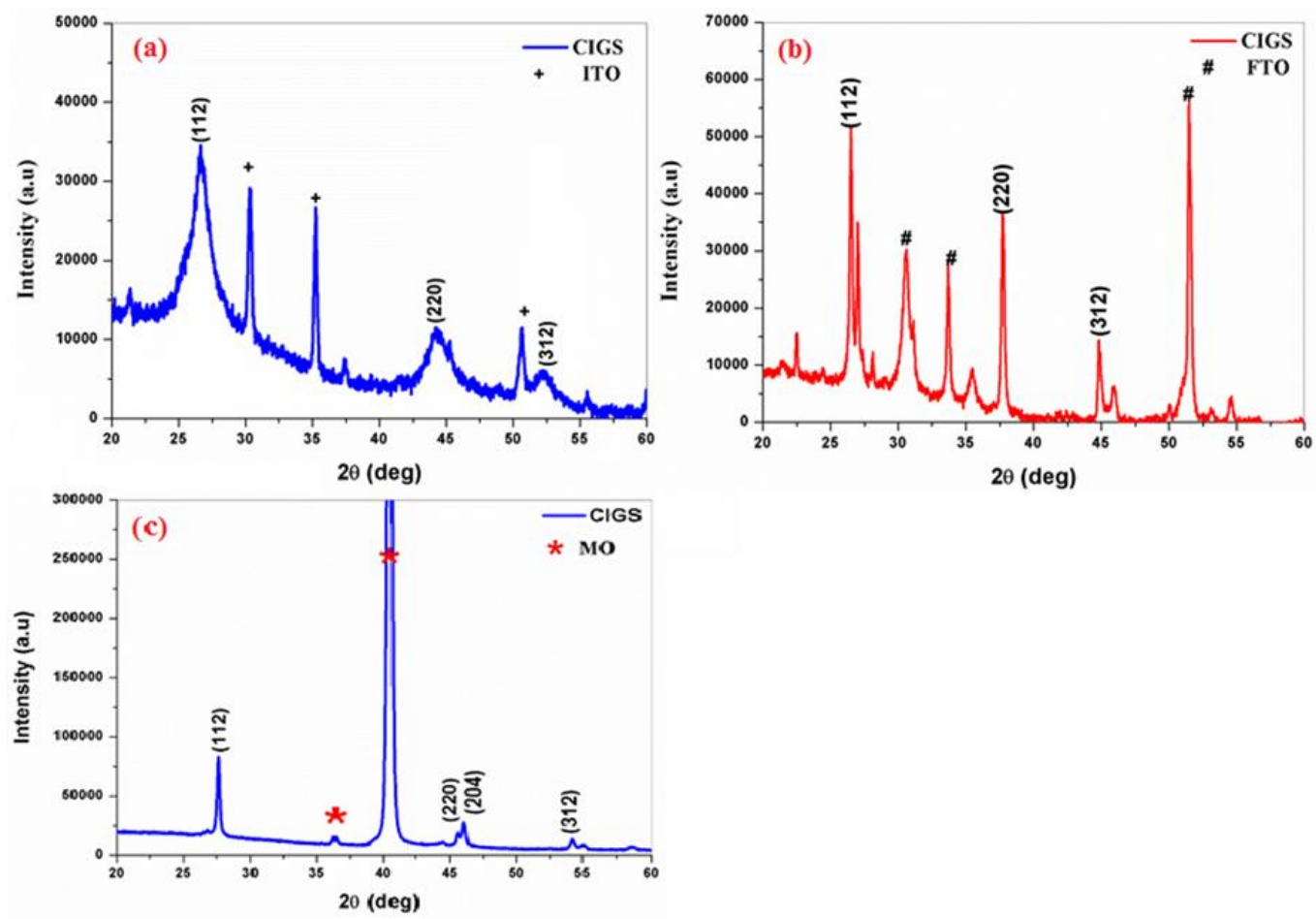

Figure 3.4 XRD analysis of CIGS thin films at different back contact: (a) ITO (b) FTO and (c) Mo substrate.

\subsubsection{Morphology analysis:}

Figure 3.4 displays the SEM images of the surface morphologies of CIGS thin film at different at different back contacts, the surface films deposited on ITO or on FTO show uniform and smooth plane, in other case the surface morphologies of the CIGS films on Mo illustrates large grain size and cylindrical grains boundaries with an average size around 1-2 $\mu \mathrm{m}[4,5]$ 

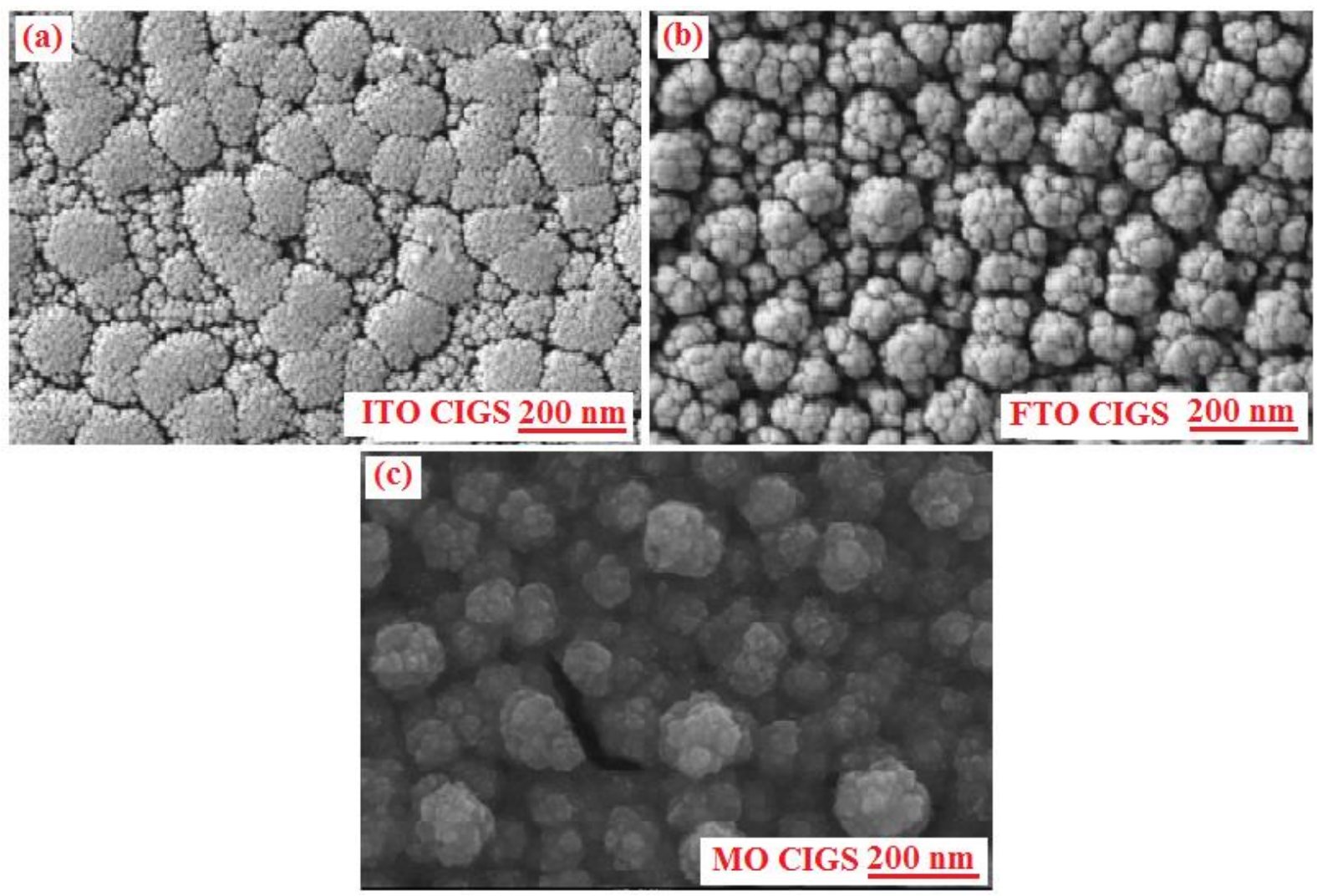

Figure 3.5 SEM images of deposited CIGS with (a) ITO (b) FTO and (c) Mo substrate.

\subsubsection{TEM analysis:}

Figure 3.5 displays the TEM images with varying the back contact for ITO, FTO and Mo we obtained different spacemen with fringe spacing $0.37 \mathrm{~nm}, 0.32 \mathrm{~nm}$ and $0.27 \mathrm{~nm}$ respectively. 

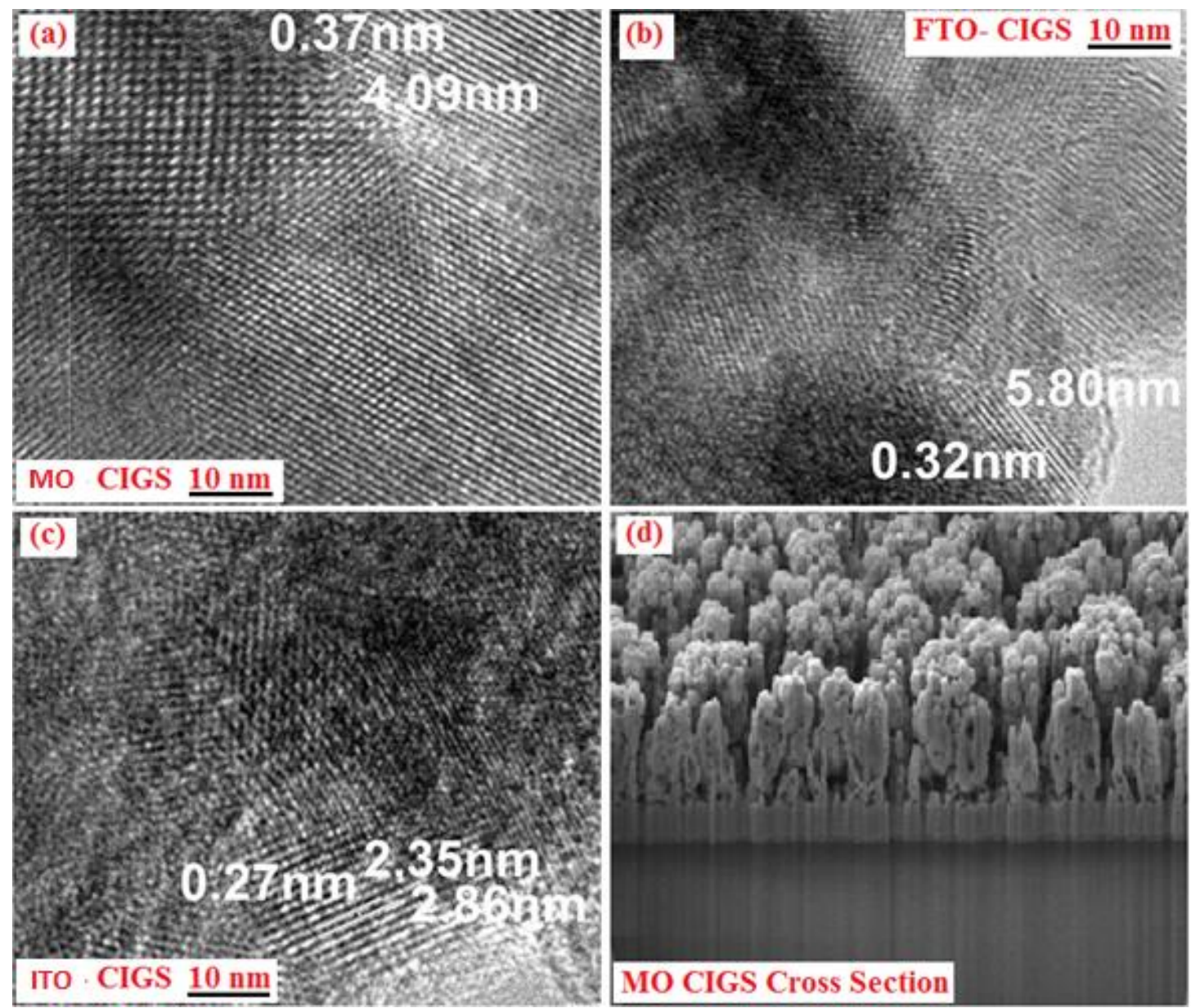

Figure 3.6 TEM images with different lattice fringe spacing (a) ITO, (b) FTO, (c) Mo and (d) Cross section of Mo.

\subsubsection{AFM analysis:}

Figure 3.6 shows AFM images of the CIGS thin films produced by different back contact, where the average grain size and the roughness are varying due to the substrate effect. The strong relation was found that the Mo substrate has higher in grain size and roughness $298 \mathrm{~nm}$ and $275 \mathrm{~nm}$ respectively. Furthermore, the Mo back contact has batter response to trap more light which is discussed in the optical properties. ITO substrate with the average grain size and surface roughness $230 \mathrm{~nm}$ and $233 \mathrm{~nm}$, respectively. For FTO-CIGS grain size and surface roughness were $250 \mathrm{~nm}$ and $290 \mathrm{~nm}$, respectively. On the other hand, a relatively large grain size was obtained when we use MoCIGS, in this case, the average grain size and the surface roughness were respectively $275 \mathrm{~nm}$ and $298 \mathrm{~nm}$ Table 3.2.

Table 3.2: Roughness and Grain Size of CIGS films with different back contact.

\begin{tabular}{|c|l|l|}
\hline Sample ID & Roughness (nm) & Grain Size (nm) \\
\hline
\end{tabular}




\begin{tabular}{|l|l|l|}
\hline ITO-CIGS & 230 & 233 \\
\hline FTO-CIGS & 250 & 290 \\
\hline MO-CIGS & 275 & 298 \\
\hline
\end{tabular}

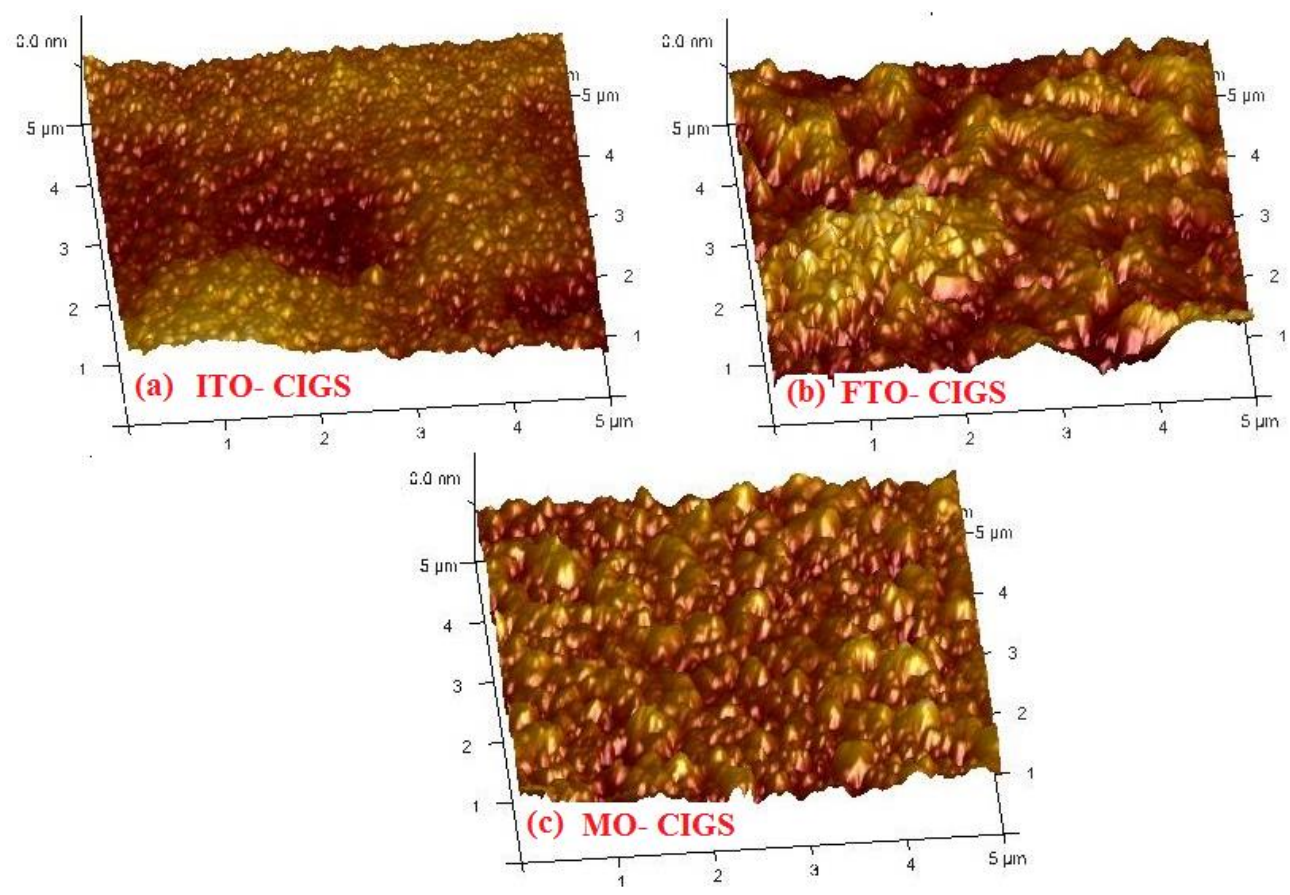

Figure 3.7 3D AFM images of (a) ITO-CIGS (b) FTO-CIGS (c) Mo-CIGS

\subsection{Optical proprieties $\mathrm{CuInGaS}_{2}$ grown by one step electrodeposition}

\subsubsection{Optical transmittance and absorbance:}

The use of back contact has an impact on the deposition rate, morphology, optical properties and optical constants which can be considered as important parameters for semiconductor. The figures 3.8 shows the optical transmittance $\mathrm{T}(\mathrm{k})$ and absorbance A (k) spectra respectively of CuInGaSe 2 films deposited on different back contacts in the wavelength range of 400 to $900 \mathrm{~nm}$. The figure 3.7 $\mathrm{b}$ of the absorbance shows that the absorption of the films deposited on MO, FTO and ITO is very remarkable especially for the Mo-CIGS sample about 0.875 but in general we note that all the films have a high absorbance and low transmittance. There is a small difference in the results in terms of percentage $(\%)$ of the absorbance and transmittance of the films. The highest transmittance value is observed for the ITO- CIGS approximately (30\%) and for the Mo-CIGS film with a lower transparency of $20 \%$. 

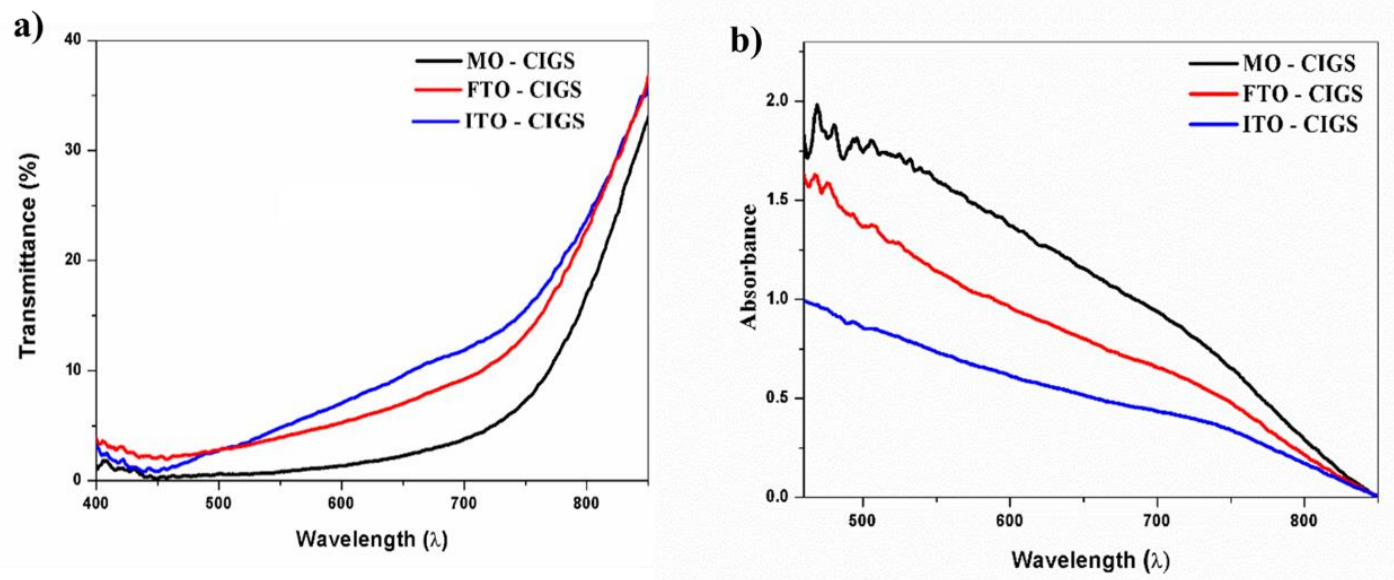

Figure 3.8: a) Optical Transmittance of the CIGS thin films with different back contact b) Optical absorbance of the CIGS films deposited by different back contact.

\subsection{2. energy band gap}

The absorption coefficient $(\alpha)$ of the $\mathrm{CuInGaSe}$ films was evaluated from the transmittance data using the following Formula 3.3: [19]

$$
\alpha=\frac{1}{\mathrm{t}} \ln \left(\frac{1}{\mathrm{~T}}\right)
$$

The energy band gap of CIGS deposited by different substrates were calculating by using the following equation (3.4) [20].

$$
(\alpha h v)^{2}=\mathrm{B}(\mathrm{h} v-\mathrm{Eg})
$$

where $\alpha$ is absorption coefficient and its calculated by equation (1), h is Planck constant, B is a constant, Eg is the bandgap energy.

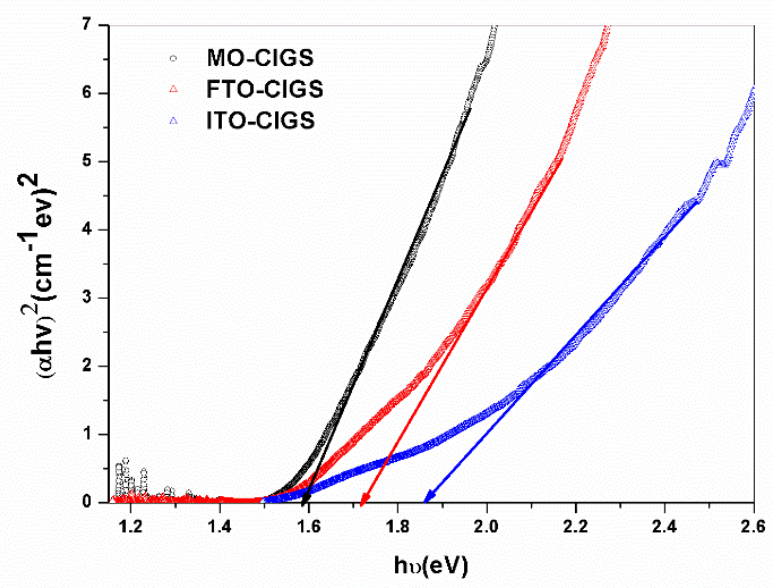

Figure 3.9 Gap energy of the CIGS thin films obtained by different back contact 
The values calculated by the equation (3.4) of the forbidden band energy are $1.75 \mathrm{eV}$ for the CIGS sample deposited on ITO and $1.87 \mathrm{eV}$ for CIGS deposited on FTO, for the CIGS sample deposited on Mo, a high absorbance and a forbidden band energy of the order of $1.9 \mathrm{eV}$ make films deposited on Mo a good choice for the application of solar cells.

\subsubsection{Optical constants:}

The determination of the optical constants gives an idea of the quality of the optical deposits also among the characteristics of the most important materials. Among those: refractive index (n), extinction coefficient $(\mathrm{k})$, real part $\left(\varepsilon_{\mathrm{r}}\right)$ and imaginary part $\left(\varepsilon_{\mathrm{i}}\right)$ of dielectric constant and can be estimated by the equations $3.5,3.6,3.7,3.8$. [21,22].

$$
\begin{gathered}
\mathrm{n}=\left(\frac{1+\mathrm{R}}{1-\mathrm{R}}\right)+\sqrt{\frac{4 \mathrm{R}}{(1-\mathrm{R})^{2}}-\mathrm{k}^{2}} \\
\mathrm{~K}=\frac{\alpha \lambda}{4 \Pi} \\
\varepsilon_{\mathrm{r}}=\mathrm{n}^{2}-\mathrm{k}^{2} \\
\varepsilon_{\mathrm{i}}=2 n k
\end{gathered}
$$

where $\mathrm{n}$ is the refractive index, $\mathrm{k}$ is the extinction coefficient, $\lambda$ is the wavelength, $\alpha$ is the absorption coefficient and $\mathrm{R}$ is the reflectance of the films. After calculating the values of refractive index $\mathrm{n}$ and extinction coefficient $\mathrm{k}$ we could derive the value of real part $\left(\varepsilon_{\mathrm{r}}\right)$ and imaginary part $\left(\varepsilon_{\mathrm{i}}\right)$ of dielectric constant. [6,7]

Figure 3.9 shows the refractive index (n) and the extinction coefficient (k) in the form of as a function of the wavelength of $\mathrm{CuInGaS}_{2}$ thin films prepared on different back contacts, we also note that their values decrease with increasing wavelength but in sometime they show a normal dispersion. Comparing with the three back contacts, we find that the values of the optical constants are approximately close, and that the Mo is the one with the slightly higher values Table 3.3 That's prove that back contact choice can be attributed to an increase in settlement density.

Table 3.3. Optical properties of the CIGS thin films with different back contact.

\begin{tabular}{|l|l|l|l|l|}
\hline Sample & $\mathbf{n}$ & $\mathbf{k}$ & $\boldsymbol{\varepsilon}_{\mathbf{r}}$ & $\boldsymbol{\varepsilon}_{\mathbf{i}}$ \\
\hline ITO-CIGS & 2.5 & 0.03 & 10 & 0.20 \\
\hline FTO-CIGS & 2.7 & 0.04 & 11 & 0.23 \\
\hline MO-CIGS & 3 & 0.05 & 12 & 0.25 \\
\hline
\end{tabular}




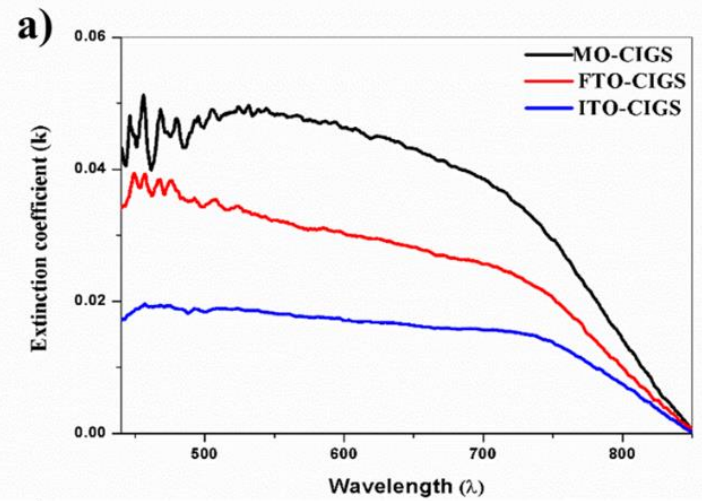

c)

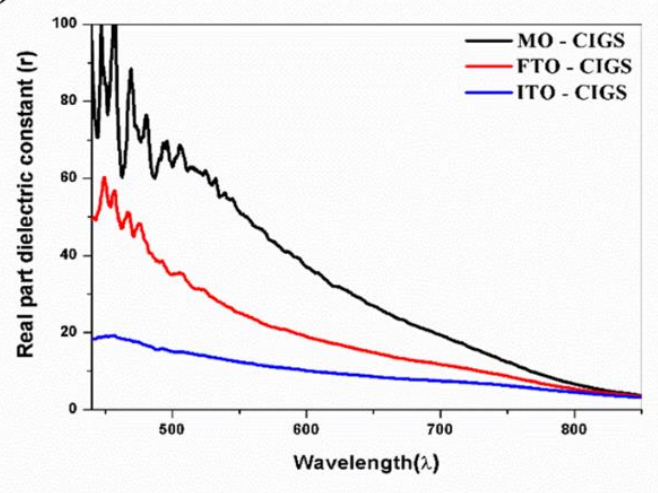

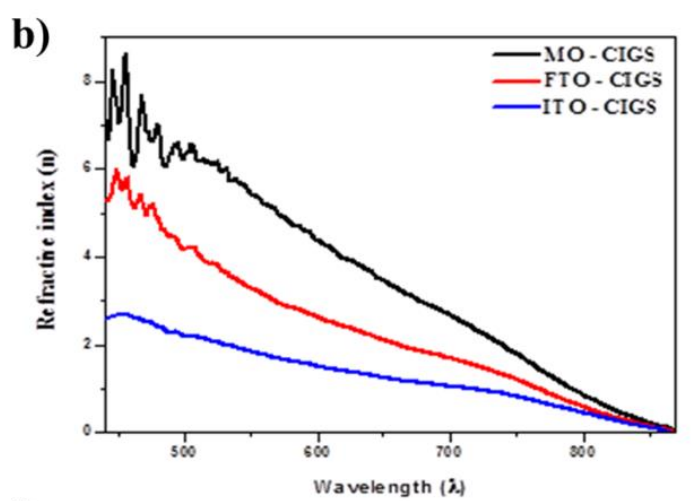

d)

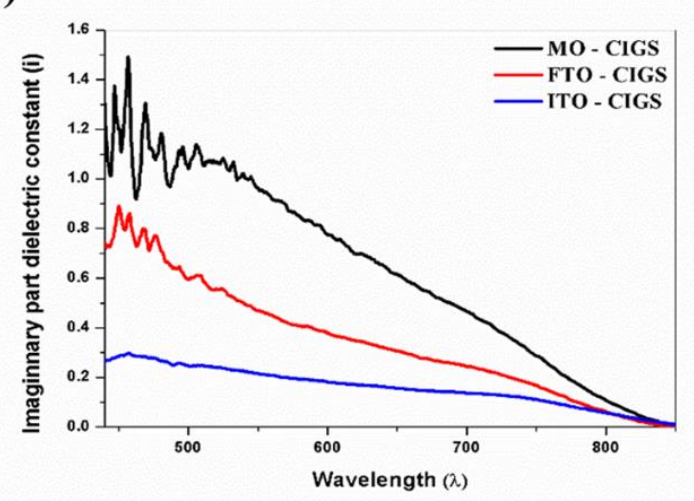

Figure 3.10: a) Extinction coefficient. b) Refractive index c) Real part dielectric constant d) Imaginary part dielectric constant of CIGS films by different back contact.

The three samples have important optical characteristics, but the thin film CIGS deposited on the Mo has values a little higher from the rest. Table 3.3 for refractive index $n=3$, extinction coefficient $\mathrm{k}=0.05$, real part $\varepsilon_{\mathrm{r}}=12$ and imaginary part $\varepsilon_{\mathrm{i}}=0.25$ of dielectric constant.

\subsubsection{Optical conductivity:}

The optical conductivity of the CIGS thin film on different back contacts was calculated using the equation 3.9:

$$
\sigma=\frac{\alpha \mathrm{nc}}{4 \pi}
$$

where $\mathrm{c}$ is the velocity of light, $\alpha$ is the absorption coefficient and $\mathrm{n}$ is the refractive index.

La Variation of the optical conductivity of the thin CIGS films deposited at different back contacts depending on the energy of the photons, as it has been noticed that CIGS deposited on the molybdenum back contact had the higher conductivity $1.10 \times 10^{15} \mathrm{~S} . \mathrm{cm}^{-1}$ where for CIGS filed on

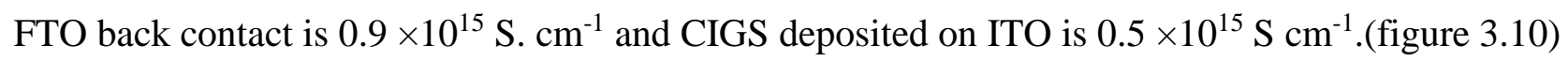




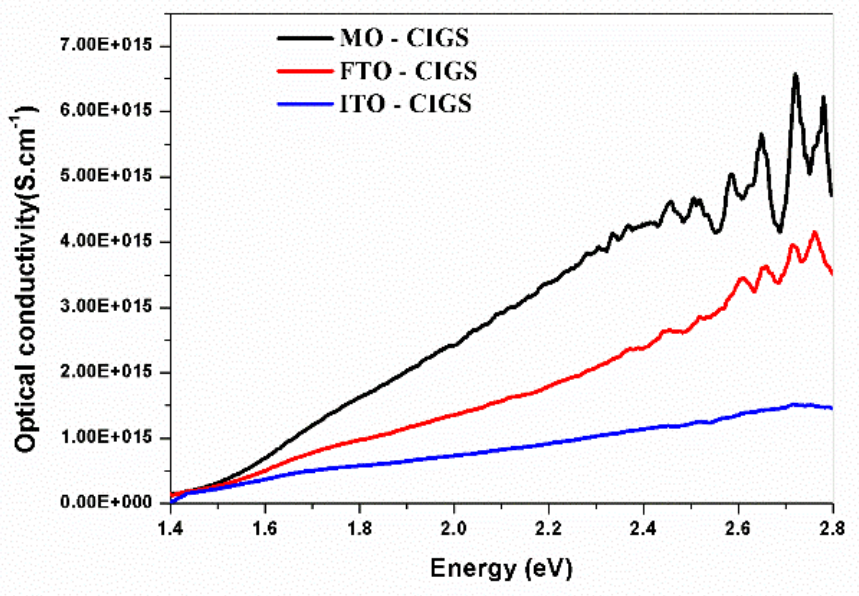

Figure 3.11. Optical conductivity of the CIGS with different back contact.

\section{Conclusion:}

CIGS thin films have been prepared and deposited by electrodeposition on different ITO, FTO and Mo back contacts to obtain high quality films at low cost and to make the right choice of deposition material for the manufacture of solar cells. The thin films prepared were studied using several characterization techniques such as X-ray diffraction to confirm the chalcopyrite structure of the CIGS deposited film. Scanning electron microscopy (SEM) to examine the surface of the three samples and confirms that the surface is smooth, with a noticeable difference in grain size. Transmission electron microscopy (TEM) has allowed us to directly access the polydispersity of nanocrystals also the inter-plane distance.

Atomic Force Microscopy (AFM) shows a smooth and dancing surface for all three cuts but with a remarkable difference in the roughness of the films. High absorbance and low transmittance are observed for films prepared with separation interval energy of about $1.6 \mathrm{eV}$. Optical constants such as the American refractive index (n), the extinction coefficient (k), the real part ( $\varepsilon r)$ and the imaginary part ( $\varepsilon i)$ of the dielectric constant were extracted using the data absorbance / transmittance and optical conductivity. By considering the values found for the optical properties, it is proposed that the Mo back contact is the right choice for the development of solar cells based on $\mathrm{CuInGaS}_{2}$. 


\section{References:}

[1] M. Kaelin, D. Rudmann, A.N.Tiwari, Low cost processing of CIGS thin film solar cells. Solar Energy, 77 (2004) 749-756.

[2] M.Steichen, M. Thomassey, S. Siebentritt, P.J. Dale, Controlled electrodeposition of Cu-Ga from a deep eutectic solvent for low cost fabrication of $\mathrm{CuGaSe}_{2}$ thin film solar cells. Physical Chemistry Chemical Physics, 13 (2011) 4292-4302

[3] N. Khoshsirat, N.A.M. Yunus, M.N. Hamidon, S. Shafie, N. Amin, Analysis of absorber and buffer layer band gap grading on CIGS thin film solar cell performance using SCAPS. Pertanika Journal of Science and Technology, 23 (2015) 241-250.

[4] J. Le Rouzo, D. Duché, C.M. Ruiz, F.Thierry, M.Carlberg, G. Berginc, Pasquinelli, J.J. Simon, L. Escoubas, F.R. Flory, Specific tools for studying the optical response of heterogeneous thin film layers. Journal of Nanophotonics, 11 (2017) 016009.

[5] S.Y. Kim, J. Kim, Fabrication of CIGS thin films by using spray pyrolysis and postselenization. Journal of the Korean Physical Society, 60 (2012) 2018-2024.

[6] N.M. Shah, J.R. Ray, K.J. Patel, V.A. Kheraj, M.S. Desai, C.J. Panchal, B. Rehani, Structural, electrical, and optical properties of copper indium diselenide thin film prepared by thermal evaporation method. Thin Solid Films, 517 (2009) 3639-3644.

[7] S. Jung, S. Ahn, J.H. Yun, J. Gwak, D. Kim, K. Yoon, Effects of Ga contents on properties of CIGS thin films and solar cells fabricated by co-evaporation technique. Current Applied Physics, 10 (2010) 990-996.

[8] T. Nakada, S. Shirakata, impacts of pulsed-laser assisted deposition on CIGS thin films and solar cells. Solar Energy Materials and Solar Cells, 95 (2011) 1463-1470.

[9] U.C. Matur, N. Baydogan, Sol-Gel Derived Cu (In, Ga) $\mathrm{Se}_{2}$ Thin Film Solar Cell. Journal of Nanoelectronics and Optoelectronics, 12 (2017) 352-358.

[10] H. Lee, H. Yoon, C. Ji, D. Lee, J.H. Lee, J.H. Yun, Y. Kim, Fabrication of CIGS films by electrodeposition method for photovoltaic cells. Journal of electronic materials, 41 (2012) 33753381.

[11] T. Feurer, P. Reinhard, E. Avancini, B. Bissig, J. Löckinger, P. Fuchs, R. Carron, T.P. Weiss, J.

Perrenoud, S. Stutterheim, S. Buecheler, Progress in thin film CIGS photovoltaics-Research and development, manufacturing, and applications. Progress in Photovoltaics: Research and Applications, 25 (2017) 645-667. 
[12] L.M. Mansfield, R.L. Garris, K.D. Counts, J.R. Sites, C.P. Thompson, W.N. Shafarman, K. Ramanathan, Comparison of cigs solar cells made with different structures and fabrication techniques. IEEE Journal of Photovoltaics, 7 (2017) 286-293.

[13] M. Mostefaoui, H. Mazari, S. Khelifi, A. Bouraiou, R. Dabou, Simulation of High Efficiency CIGS solar cells with SCAPS-1D software. Energy Procedia, 74 (2015) 736-744.

[14] T.A. Reese, S.B. Schujman, R.J. Matyi, Structure evolution in CIGS deposition: An X-ray diffraction analysis with Rietveld whole-pattern refinement. In Photovoltaic Specialist Conference (PVSC), (2014) IEEE 40th 1691-1695.

[15] U.C. Matur, S. Akyol, N. Baydoğan, H. Cimenoglu, The Optical Properties of CIGS Thin Films Derived by Sol-gel Dip Coating Process at Different Withdrawal Speed. Procedia-Social and Behavioral Sciences, 195 (2015) 1762-1767.

[16] M.B. Rabeh, N. Khedmi, M.A. Fodha, M. Kanzari, the effect of thickness on optical band gap and N-type conductivity of $\mathrm{CuInS}_{2}$ thin films annealed in air atmosphere. Energy Procedia, 44 (2014) $52-60$.

[17] S. Ullah, M. Mollar, B. Marí, Electrodeposition of $\mathrm{CuGaSe}_{2}$ and $\mathrm{CuGaS}_{2}$ thin films for photovoltaic applications. Journal of Solid State Electrochemistry, 20 (2016) 2251-2257.

[18] B. Xu, X. Li, Z. Qin, C. Long, D. Yang, J. Sun, L. Yi, Electronic and optical properties of $\mathrm{CuGaS}_{2}$ : First-principles calculations. Physica B: Condensed Matter, 406 (2011) 946-951.

[19] J. Ederth, P. Johnsson, G.A. Niklasson, A. Hoel, A. Hultåker, P. Heszler, C.G. Granqvist, A.R. Van Doorn, M.J. Jongerius, D. Burgard, Electrical and optical properties of thin films consisting of tin-doped indium oxide nanoparticles. Physical Review B, 68 (2003) 155410. 


\section{Chapter IV}

\section{Copper-indium-Gallium disulfide (CIGS) thin films grown by Spray pyrolysis for solar cells.}

\section{Contents}

1. Investigation of CIGS and CIS grown by Spray pyrolysis 87

2. Investigation of structural and morphological properties of CIGS grown by Spray pyrolysis

2.1. structural proprieties of CIS and CIGS 87

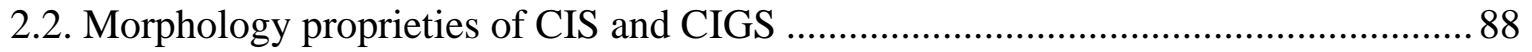

3. Investigation of optical properties of polycrystalline CIGS grown by Spray pyrolysis technique.

3.1. Absorbance, transmittance and gap energy of CIGS grown by Spray pyrolysis technique.

3.2. Optical constants of CIGS grown by Spray pyrolysis technique. 91

4. Suitable annealing time of Copper-indium Gallium disulfide (CIGS) thin films grown by Spray pyrolysis

4.1. Copper-indium Gallium disulfide (CIGS) thin films grown by Spray pyrolysis ........93

4.2. structural and morphology properties of Copper-indium Gallium disulfide (CIGS) thin films grown by Spray pyrolysis. .94

4.2.1. XRD analysis of (CIGS) thin films grown by Spray pyrolysis ............................. 94

4.2.2. SEM analysis of (CIGS) thin films grown by Spray pyrolysis ............................. 96

4.2.3. TEM analysis of (CIGS) thin films grown by Spray pyrolysis .............................97

4.2.4. AFM analysis of (CIGS) thin films grown by Spray pyrolysis ..............................98

4.3. Optical and electrical proprieties of (CIGS) thin films grown by Spray pyrolysis:.. 100

4.3.1. Absorbance, transmittance and gap energy: ........................................................... 100

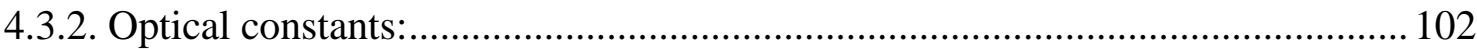

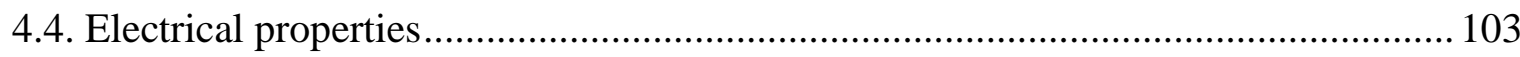


5. Simulation performance of CIGS grown by Spray pyrolysis technique......................... 104

5.1. Simulation of the performance of CIGS grown by spray pyrolysis technique ......... 106

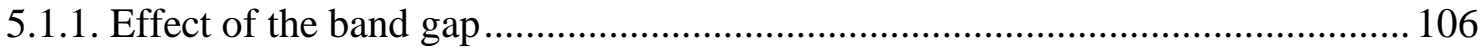

5.1.2. Effects of operating temperature on the performance of CIGS solar cells......... 108

5.1.3. Effect of shallow acceptor density on the performance of the CIGS cell .......... 109 
In this chapter we report the effect of spray pyrolysis technique to control the growth of CIGS films for solar cells application. The chapter is containing two part, first we will study the effect of experimental parameter like the concentration of precursors also the annealing process which is the key factor for Improving the performance of solar cells. The films were characterized by X-ray diffraction (XRD), Surface Electron Microscopy (SEM), Energy dispersive spectroscopy (EDS), Transmission electron microscopy (TEM), Atomic Force Microscope (AFM), UV-Vis spectroscopy and with four probe method to get an idea of the structural, Morphology, Optical and electrical properties of the thin films. The annealing temperature has a great impact on the Optical, morphology and electrical properties of the films, The Hall effect has proved to be a convenient and useful tool for penetrating charge transport properties in the solid state and is routinely used as a standard materials characterization method.

In the second part, we will investigate the performance of solar cell CIGS, grown by the spray technique, by simulator scapes to have idea about the efficiency of solar cell.

\section{Investigation of CIGS and CIS grown by Spray pyrolysis}

Thin film was deposited on glass substrates at $370{ }^{\circ} \mathrm{C}$ using spray pyrolysis. CIS and CIGS thin films were prepared using different $\mathrm{CuCl}_{2} 10^{-2} \mathrm{M}$ precursors for copper, $10^{-2} \mathrm{M} \mathrm{InCl}_{3}$ for indium, $10^{-}$ ${ }^{2} \mathrm{M} \mathrm{GaCl}_{2}$ for gallium and $3 \times 10^{-2} \mathrm{M} \mathrm{SC}_{2}\left(\mathrm{NH}_{2}\right)_{2}$ for sulfur, which were dissolved in distilled water to obtain a solution that was sprayed in air on preheated glass substrates of $2 \mathrm{~cm} \times 2 \mathrm{~cm} \times 0.1 \mathrm{~cm}$ dimension, at $370{ }^{\circ} \mathrm{C}$, using the spray rate of $\mathrm{D}=1 \mathrm{~mL} \mathrm{~min}^{-1}$. The distance between the atomizer and the glass substrate was $25 \mathrm{~cm}$ and the spray time was set at $\mathrm{t}=30 \mathrm{~min}$. The structural, optical and electrical properties of the prepared films was assessed, showing optimal optical parameters and low electrical resistivity.

\section{Investigation of structural and morphological properties of CIGS grown by Spray pyrolysis}

\subsection{Structural proprieties of CIS and CIGS}

In order to confirm the structure of $\mathrm{CuInS}_{2}$ and $\mathrm{CuInGaS}_{2}$ semiconductor material, the thin layers deposited on glass substrates characterized by the XRD technique are deposited [1] All the deposited thin films have a polycrystalline structure and we can observe some peaks corresponding to (112), 
(200), (220/204), (312/116), (224), (400) and (316), which correspond to the crystalline planes of the CIS, characteristic of chalcopyrite structure or sphalerite phase. These CIS and CIGS thin films have characteristic diffraction peaks (112) (221) and (116) and its crystals have a tetragonal structure (JCPD 65-1572). It is also interesting to note that the relative intensity of the diffraction peak (112) is the most intense (Figure 4.1), for calculation of the lattice parameters could be used two equations 4.10 and 4.11 taking into consideration the following values: the angle $2 \theta$ and the value of the plan hkl correspondent.

$$
\frac{1}{\mathrm{~d}^{2}}=\frac{\mathrm{h}^{2}+\mathrm{k}^{2}}{\mathrm{a}^{2}}+\frac{\mathrm{l}^{2}}{\mathrm{c}^{2}}
$$

Where (a) and (c) are the network parameters and (d) is the network spacing.

The grain size of the thin layers was calculated using Scherrer equation (Equation. 4.2),

$$
n \lambda=d_{h k_{l}} \sin (\theta)
$$

Where $\lambda=1.54$ is the X-ray wavelength used, $\mathrm{d}_{\mathrm{hkl}}$ is the half-full-width (FWHM) and $\theta_{\mathrm{hkl}}$ is the Bragg angle. From the equations we get the values of $\mathrm{a}=5.42 \AA$ and $\mathrm{c}=10.6 \AA$;

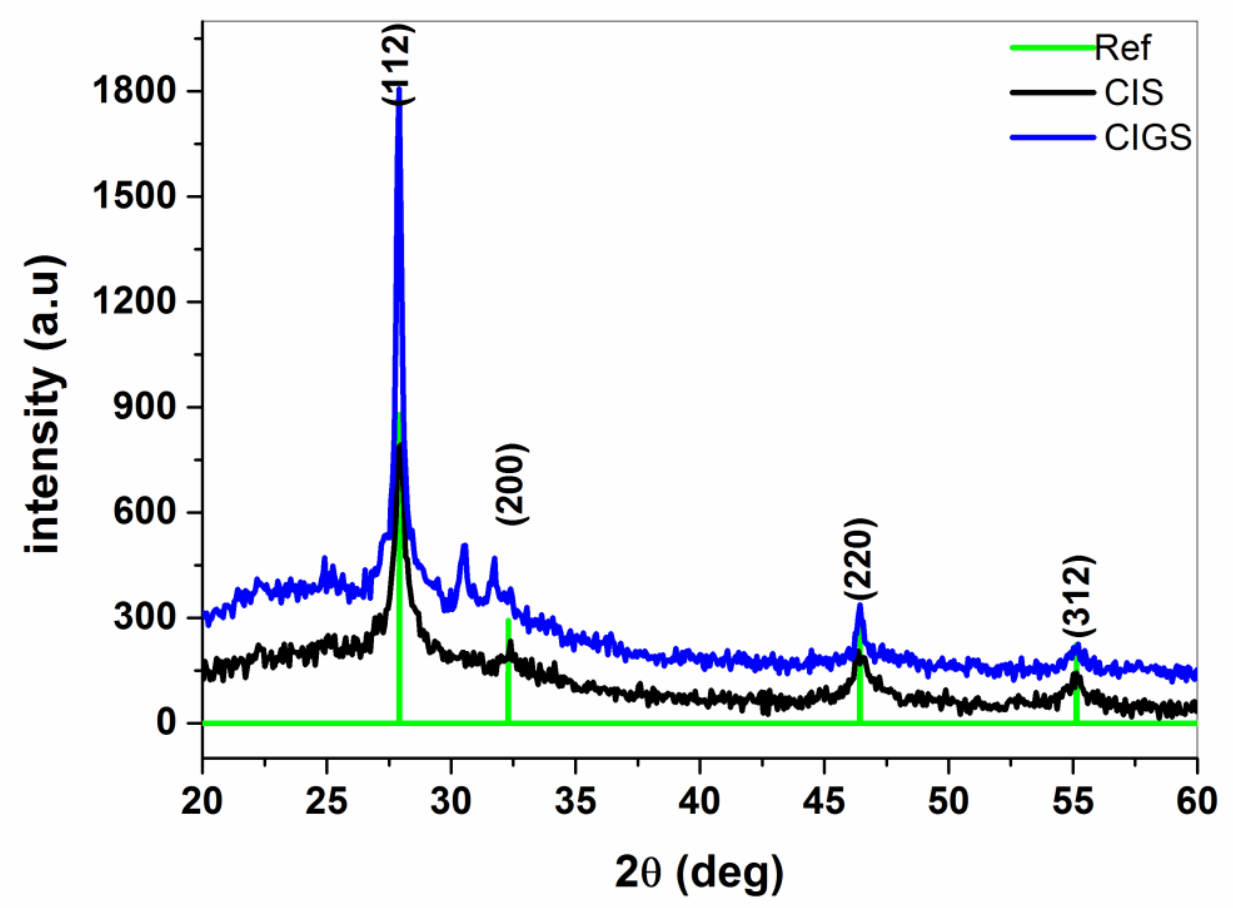

Figure 4.1. X-ray diffraction patterns of the prepared CIS and CIGS films.

\subsection{Morphology proprieties of CIS and CIGS}


Figure 4.2 (a) and (b) show plan views of SEM of CIS and CIGS thin layers, respectively. CIGS was deposited on a glass substrate using a spray pyrolysis technique. Figure 2(b) demonstrates that well defined cylindrical grains with an average grain size of 1-2 $\mu \mathrm{m}$ are formed. Grain size decreased with Ga content and pores were observed along the grain boundaries.
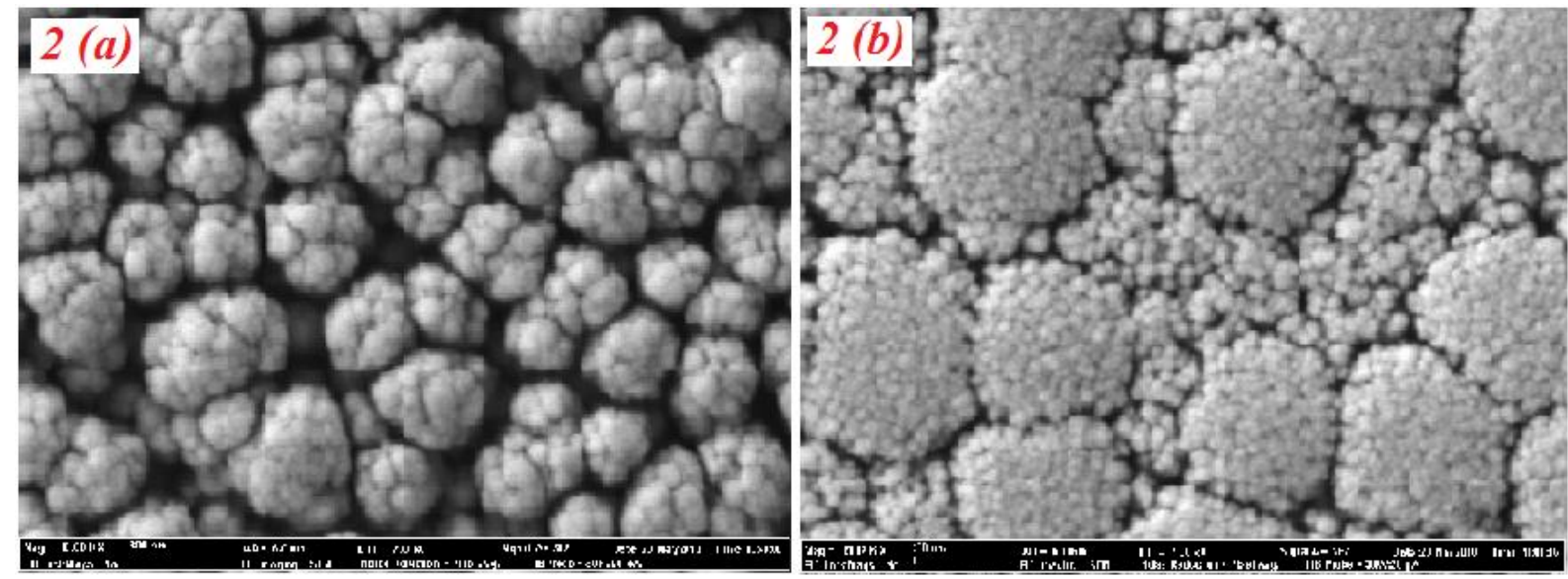

Figure 4.2. (a) SEM image of the CIS and (b) CIGS thin film

\section{Investigation of optical properties of polycrystalline CIGS grown by Spray pyrolysis technique.}

\subsection{Absorbance, transmittance and gap energy of CIGS grown by Spray pyrolysis technique.}

Figures 4.3 shows the absorbance and transmittance spectra of the prepared CIS and CIGS thin films recorded in the $400-800 \mathrm{~nm}$ wavelength range. It can be seen that all films have a high absorbance and low transmittance despite a small difference between the results in terms of the absorbance and transmittance \% of the films. CIGS thin film has the lowest 3\% transparency at 800 $\mathrm{nm}$ than CIS film. The prepared layers have a high visible region absorbance with a maximum value of about $2.5 \%$. The optical bandgap energy of the films was estimated from the straight-line plot of $(\alpha h)^{2}$ versus hv for direct band gap semiconductors and by the equation 4.3 and 4.4 [2],

$$
\begin{aligned}
& (\alpha h v)^{2}=\mathrm{B}(\mathrm{h} v-\mathrm{Eg}) \\
& \alpha=\frac{1}{\mathrm{t}} \ln \left(\frac{1}{\mathrm{~T}}\right)
\end{aligned}
$$


Where $\alpha$ is the absorption coefficient, $\mathrm{h}$ is Planck constant, Eg is the forbidden band energy, $\mathrm{t}$ is the thickness of the layers, and B is a constant.

a)

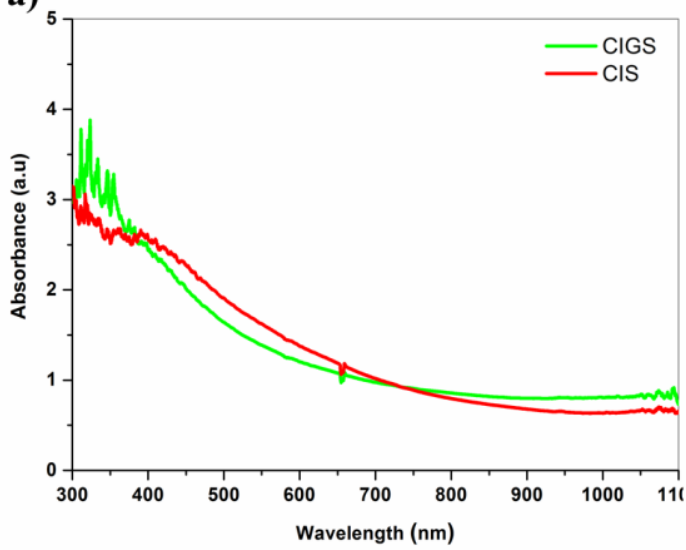

b)

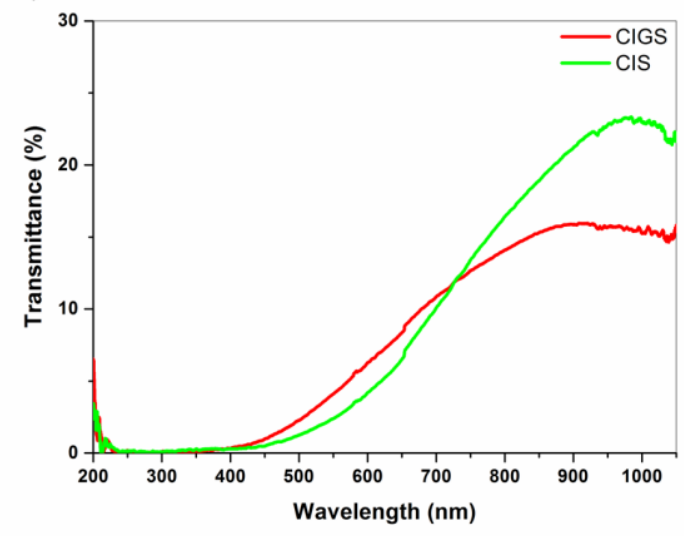

Figure 4.3. a) Optical absorbance b) Optical transmittance spectra of the CIS/CIGS thin films obtained by spray pyrolysis.

Figure 4.4 shows the variation of (ahv) $)^{2}$ according to the photon the energy (hv) of the thin layers Estimated values of bandgap energy are tabulated in Table 3.1 The $E_{\mathrm{g}}$ values are between $1.6 \mathrm{eV}$ and $1.78 \mathrm{eV}$ and are in good agreement with the reported values.

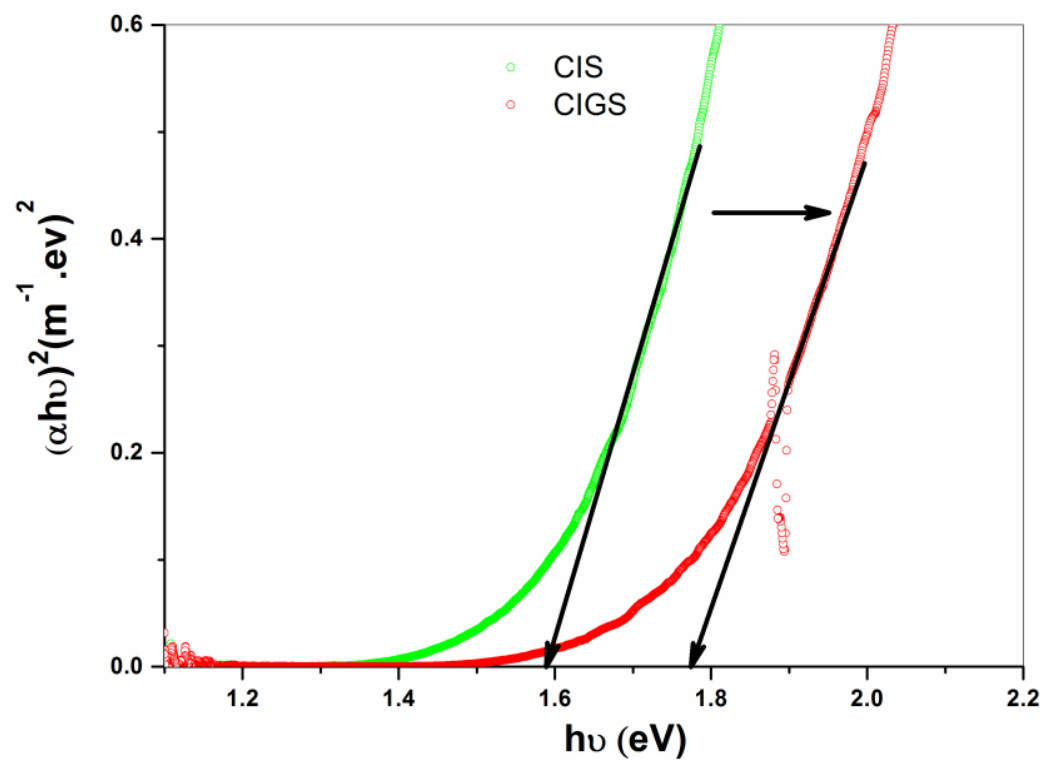

Figure 4.4. Band gap energy of the CIS/CIGS thin films obtained by spray pyrolysis. 
Figure 4.4 indicates the variation of $(\alpha h v)^{2}$ according to photon energy (hv) of the CIS/CIGS thin films deposited by spray pyrolysis. The calculated values of band gap energy are $1.6 \mathrm{eV}$ for $\mathrm{CuInS} \mathrm{S}_{2}$ and $1.78 \mathrm{eV}$ for $\mathrm{CuInGaSe}_{2}$, which are in good agreement with previously reported values [3]. For the films deposited by CIS, a strong absorbance and band gap energy of the order of $1.6 \mathrm{eV}$ make the films prepared by this precursor a good choice for solar cells application [4].

\subsection{Optical constants of CIGS grown by Spray pyrolysis technique.}

Figures 4.5 shows the optical constants, namely refractive index (n), extinction coefficient (k), real part $\left(\varepsilon_{\mathrm{r}}\right)$ and imaginary part $\left(\varepsilon_{\mathrm{i}}\right)$ of dielectric constant for $\mathrm{CuInS}_{2}$ and $\mathrm{CuInGaS}$, which were calculated using Eqs. (4.5) (4.6) (4.7) and (4.8) and whose values are tabulated in table 4.1 [5].

$$
\begin{gathered}
\mathrm{n}=\left(\frac{1+\mathrm{R}}{1-\mathrm{R}}\right)+\sqrt{\frac{4 \mathrm{R}}{(1-\mathrm{R})^{2}}-\mathrm{k}^{2}} \\
\mathrm{~K}=\frac{\alpha \lambda}{4 \Pi} \\
\varepsilon_{\mathrm{r}}=\mathrm{n}^{2}-\mathrm{k}^{2} \\
\varepsilon_{\mathrm{i}}=2 n k
\end{gathered}
$$

Where $\mathrm{n}$ is the refractive index, $\mathrm{k}$ is the extinction coefficient, $\lambda$ is the wavelength, $\alpha$ is the absorption coefficient and $\mathrm{R}$ is the reflectance of the films. 

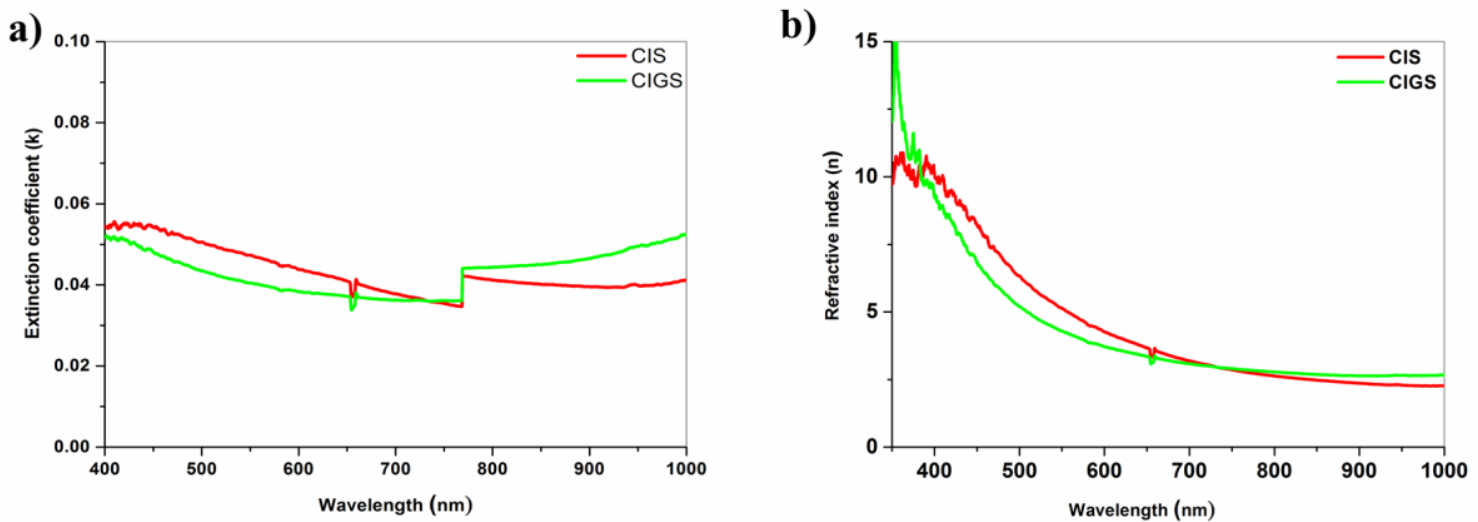

c)
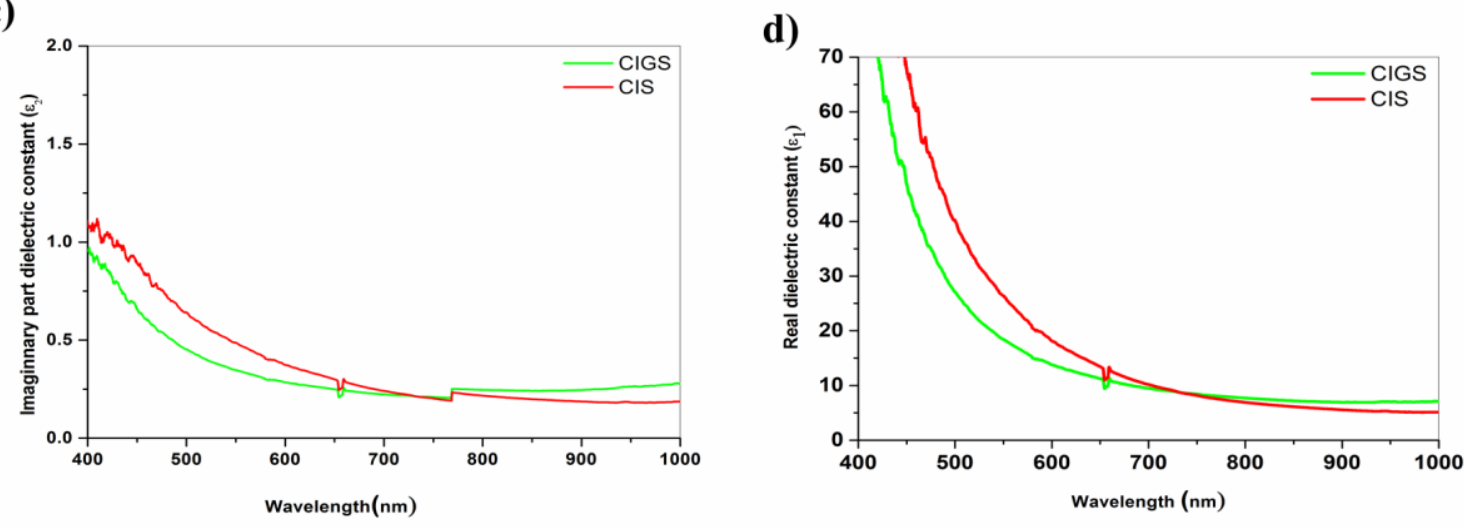

Figure 4.5. a) Extinction coefficient. b) Refractive index c) Imaginary part of dielectric constant d) Real part of dielectric constant of the CIS/CIGS thin films obtained by spray pyrolysis.

The measured refractive index value for the prepared CIGS films is attributed to the thickness of the films. The high value of the extinction coefficient is observed for this layer because of the strong absorption in this film compared to CIS. The high values of the extinction coefficient are attributed to high absorbance. The real and imaginary part of the dielectric constant decreases with the wavelength and the maximum values are observed for the CIGS sample (Table 4.1).

Table 4.1. Optical constants for CIS $\backslash$ CIGS thin films deposited with spray pyrolysis

\begin{tabular}{|l|l|l|l|l|}
\hline Sample & \multicolumn{1}{|c|}{$\mathbf{n}$} & \multicolumn{1}{|c|}{$\boldsymbol{\varepsilon}_{\mathrm{r}}$} & $\boldsymbol{\varepsilon}_{\mathrm{i}}$ \\
\hline CIS & $\mathbf{2 . 5}$ & $\mathbf{0 . 0 4}$ & $\mathbf{8 0}$ & $\mathbf{0 . 2 5}$ \\
\hline CIGS & $\mathbf{3 0}$ & $\mathbf{0 . 0 5}$ & $\mathbf{1 0}$ & $\mathbf{0 . 3 0}$ \\
\hline
\end{tabular}

\subsection{Electrical properties of CIGS grown by Spray pyrolysis technique.}

We used four-point probe methods to give electrical resistance using equation (4.9):

$$
\mathrm{R}=\mathrm{R}_{\mathrm{s}} \times \mathrm{t}
$$


Where $t$ is the thickness and $R_{s}$ is the resistivity of the thin layer.

CIS/CIGS thin films prepared for different precursors are listed in Table 4.2. The resistivity of the four thin layers is of the order of $10^{-2}(\Omega \mathrm{cm})$, the lowest is observed resistivity values for the layers are annealed and the resistivity is in the vicinity of $0.65(\Omega \mathrm{cm})$. The values obtained by the reported work. The low values of resistivity are attributed to the electrical nature of CIS and CIGS semiconductors.

Table 4.2. The resistivity for CIS/CIGS thin films deposited with spray pyrolysis.

\begin{tabular}{|l|r|c|r|}
\hline Samples & $\mathbf{R}_{\mathrm{s}}(\boldsymbol{\Omega} / \mathbf{s q})$ & $\mathbf{R}\left(\mathbf{1 0}^{-2} \Omega \mathrm{cm}\right)$ & $\mathrm{E}_{\mathrm{g}}(\mathrm{eV})$ \\
\hline CIS & 404.4 & 606.6 & 1.62 \\
\hline CIGS & 435.1 & 652.6 & 1.78 \\
\hline
\end{tabular}

\section{Suitable annealing time of Copper-indium Gallium disulfide (CIGS) thin films grown by Spray pyrolysis}

\subsection{Copper-indium Gallium disulfide (CIGS) thin films grown by Spray pyrolysis}

The CIGS thin films were successfully deposited on glass by using spray pyrolysis technique. Spray technique involves preparing CIGS from electrolytic bath containing $\mathrm{Cu}-\mathrm{In}$-Ga-S elements in the form of $\mathrm{CuCl} 2, \mathrm{InCl} 3, \mathrm{GaCl} 3, \mathrm{SC}(\mathrm{NH} 2) 2$, Thin CIGS films were prepared using different precursors, $\mathrm{CuCl} 2$ (1.10-2 M), InCl3 (1.10-2 M ), GaCl2 (1.10-2 M) and SC2 (NH2) 2 (3.10-2 M) as a sulfur source which were dissolved in distilled water. The substrate temperature was kept at 370 ${ }^{\circ} \mathrm{C}$. N2 was used as the carried gas and distance between the nozzle to substrate was set to $25 \mathrm{~cm}$, the spray rate was $1 \mathrm{ml} / \mathrm{min}$ with deposition time for $30 \mathrm{~min}$ as is shown in figure 4.6 [6].

During the spray all parameters were fixed, Finally, the samples were rinsed under deionized water (DI) and dried in $60{ }^{\circ} \mathrm{C}$ oven for $5 \mathrm{~min}$. for the crystallinity improvement the as - deposited samples were annealed on hot plate at $370{ }^{\circ} \mathrm{C}$ for different annealing time. 


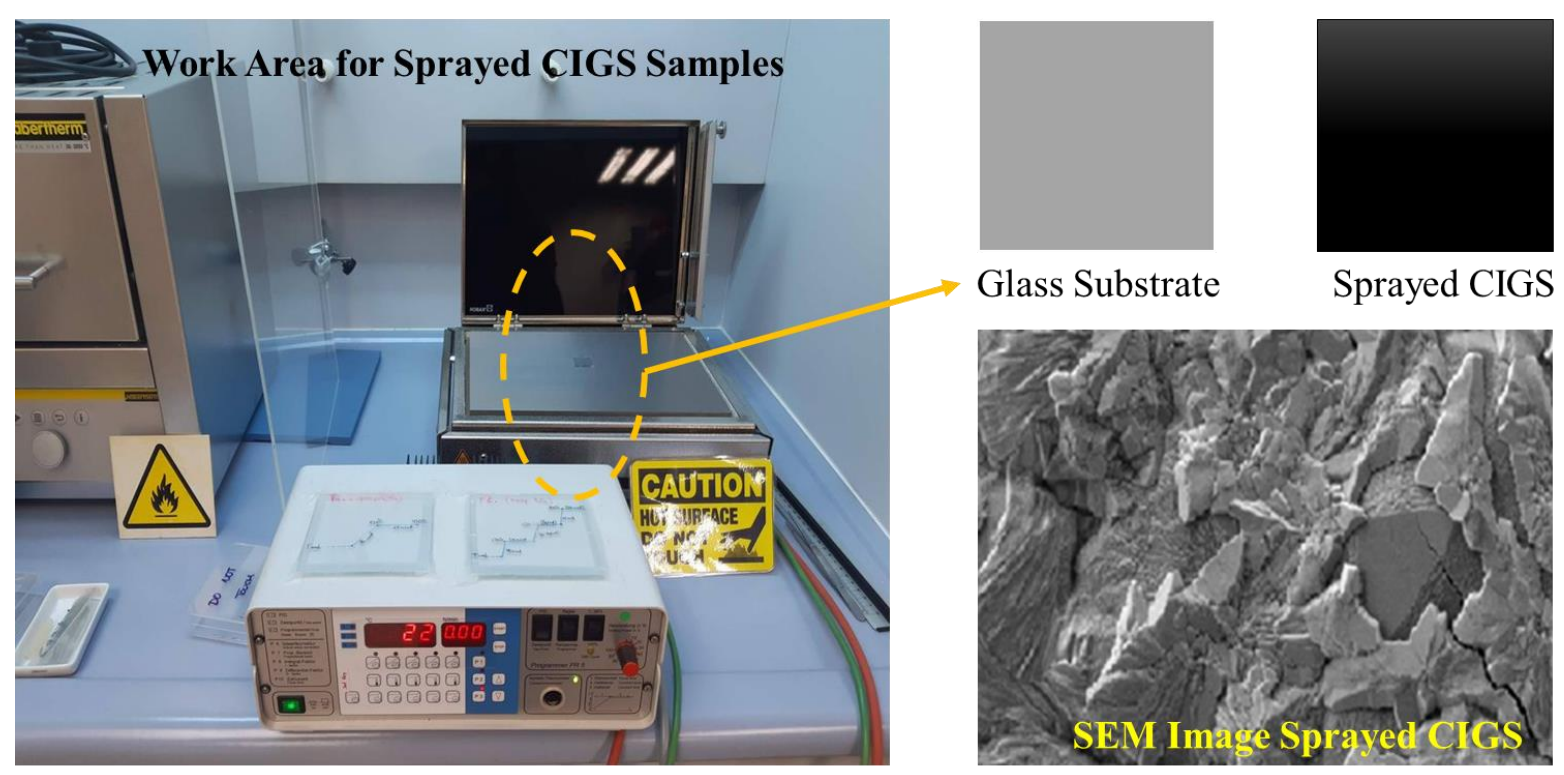

Figure 4.6 Preparation of CIGS thin films Sprayed

\section{2. structural and morphology properties of Copper-indium Gallium disulfide (CIGS) thin films grown by Spray pyrolysis}

\subsubsection{XRD analysis of (CIGS) thin films grown by Spray pyrolysis}

The crystal structure of CIGS at different annealing time (5,10 and $20 \mathrm{~min}$ ) composite were investigated by X-ray diffraction (XRD) using a Rigaku Ultima IV diffractometer in the BraggBrentano configuration using $\mathrm{CuK} \alpha$ radiation $(\lambda=1.54060 \AA)$. Chemical composition, surface morphology and topography were characterized using energy dispersive spectroscopy (EDS) and field emission scanning electron microscopy (FESEM) a Zeiss ULTRA 55 model equipped with an In-Lens SE detector respectively. Optical properties of the CIGS films were measured at room temperature by using IR-VIS-UV spectrophotometer at wavelength within the range (400-900) nm.

\section{a. lattice parameters:}

To calculate the lattice parameters could be used two equations 4.10 and 4.11 taking into consideration the following values: the angle $2 \theta$ and the value of the plan hkl correspondent [7]:

$$
\begin{gathered}
\frac{1}{d^{2}}=\frac{h^{2}+k^{2}}{a^{2}}+\frac{l^{2}}{c^{2} .} \\
n \lambda=d_{h_{1}} \sin (\theta)
\end{gathered}
$$

$\mathrm{a}, \mathrm{c}$ : lattice parameters, $\mathrm{d}_{\mathrm{hkl}}$ is the lattice spacing of hkl. $\mathrm{h}, \mathrm{k}$ and $\mathrm{l}$ are the Miller indices, $\mathrm{k}$ is the wavelength of the $\mathrm{CuK}_{\alpha}$ radiation $(0.154 \mathrm{~nm}), 2 \theta$ is the diffraction angle of the corresponding plane. After the calculation we got the lattice parameters. 


$$
\mathrm{a}=5,54 \AA \text { and } \mathrm{c}=11,14 \AA
$$

\section{b. Grain size and effective lattice strain:}

Effective lattice strain can give us an idea about the imperfections and deformations of the grains in the level of the thin layer sprayed, for the calculation we can use the following equation (4.12) where it links the grain size with the effective lattice strain [8]. The grain size of the films sprayed CIGS increased from $2.8 \mathrm{~nm}$ to $7.67 \mathrm{~nm}$ with increase of annealing time (Table 4.3).

$$
\beta \cos (\theta)=\frac{\mathrm{k} \lambda}{\mathrm{D}}+4 \varepsilon \sin (\theta)
$$

Where $\mathrm{K}$ is a constant whose value was taken as $0.94, \mathrm{k}$ is the wavelength of $\mathrm{X}$-ray used, is the full-width half maximum (FWHM), $\theta$ is the Bragg angle, D is grain size and $\varepsilon$ is the effective lattice strain.

\section{c. Dislocation density:}

The dislocations density can be estimated by measurements made by Transmission Electron Microscopy (TEM) which gives more precision on a specific area of the thin layer or by calculations from X-ray diffraction data (XRD) [9]. The dislocation density of the crystal was evaluated using the formula [4.13]. Where the dislocation density and D is the grain size of the thin films. The deposition condition of spayed CIGS thin films is presented in Table 4.2, where all the parameters are constant except annealing time (5,10 and $20 \mathrm{~min})$.

$$
\gamma=1 / \mathrm{D} 2
$$

Table 4.3: the deposition conditions of sprayed CIGS

\begin{tabular}{|c|c|c|c|c|}
\hline Samples Name & $\begin{array}{l}\text { Annealing } \\
\text { temperature }\left({ }^{\circ} \mathrm{C}\right)\end{array}$ & Pression (bar) & $\begin{array}{l}\text { Thickness } \\
(\boldsymbol{\mu m})\end{array}$ & $\begin{array}{l}\text { Annealing } \\
\text { time }(\mathrm{min})\end{array}$ \\
\hline Sprayed CIGS 1 & 370 & 2.5 & 2 & 5 \\
\hline Sprayed CIGS 2 & 370 & 2.5 & 2 & 10 \\
\hline Sprayed CIGS 3 & 370 & 2.5 & 2 & 20 \\
\hline
\end{tabular}

Figure 4.6 shows representative XRD peak with chalcopyrite structure of the annealed CIGS samples. The major XRD peaks are observed to be oriented to [112, 220/204 and 312/116] diffraction planes. The pattern well matches with tetragonal structure JCPDS NO. 075-0104 corresponding to 
CIGS. The diffraction peaks confirm that the intensity of the peaks increases due to different annealing time $(5,10$ and $20 \mathrm{~min})$.

Table 4.4: Parameters of XRD of sprayed CIGS films.

\begin{tabular}{|l|c|c|c|}
\hline \multicolumn{1}{|c|}{ Sample } & Grain Size $(\mathbf{n m})$ & Dislocation density $\left(\mathrm{nm}^{-1}\right)$ & Lattice strain $(\varepsilon)$ \\
\hline Sprayed CIGS1 & 429.82 & $5.41 .10^{-6}$ & 0.62 \\
\hline Sprayed CIGS2 & 546.26 & $3.35 .10^{-6}$ & 0.56 \\
\hline Sprayed CIGS3 & 567.22 & $3.10 .10^{-6}$ & 0.52 \\
\hline
\end{tabular}

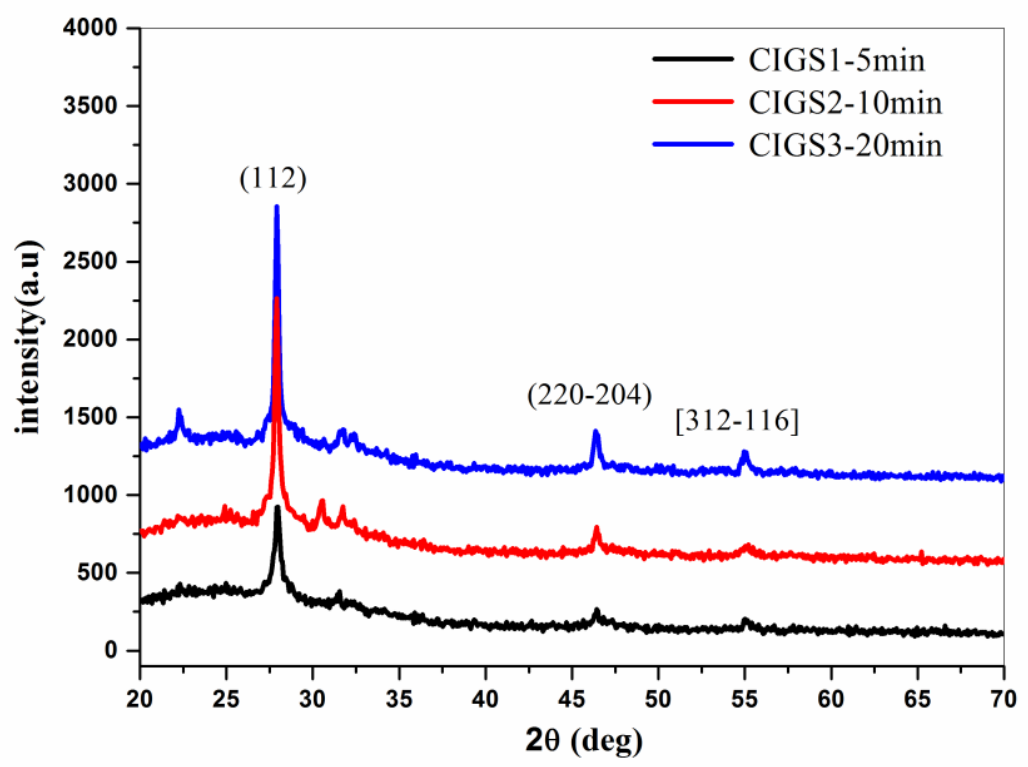

Figure.4.6. XRD results for sprayed CIGS with different annealing time.

\subsubsection{SEM analysis of (CIGS) thin films grown by Spray pyrolysis}

Figure 4.7 shows the surface morphology of the CIGS films sprayed with different annealing time. The variation in the grain size from 429 to $567 \mathrm{~nm}$ (Table 4.4) of the samples evident that the annealing time has an impact on it is agreement with XRD results of figure.4.6. The samples treatment of the surface of the thin films at temperature $370{ }^{\circ} \mathrm{C}$ for 20 minutes plays an essential role for the enlargement of the grain size which is considered important for the effectiveness of the absorber layer. 


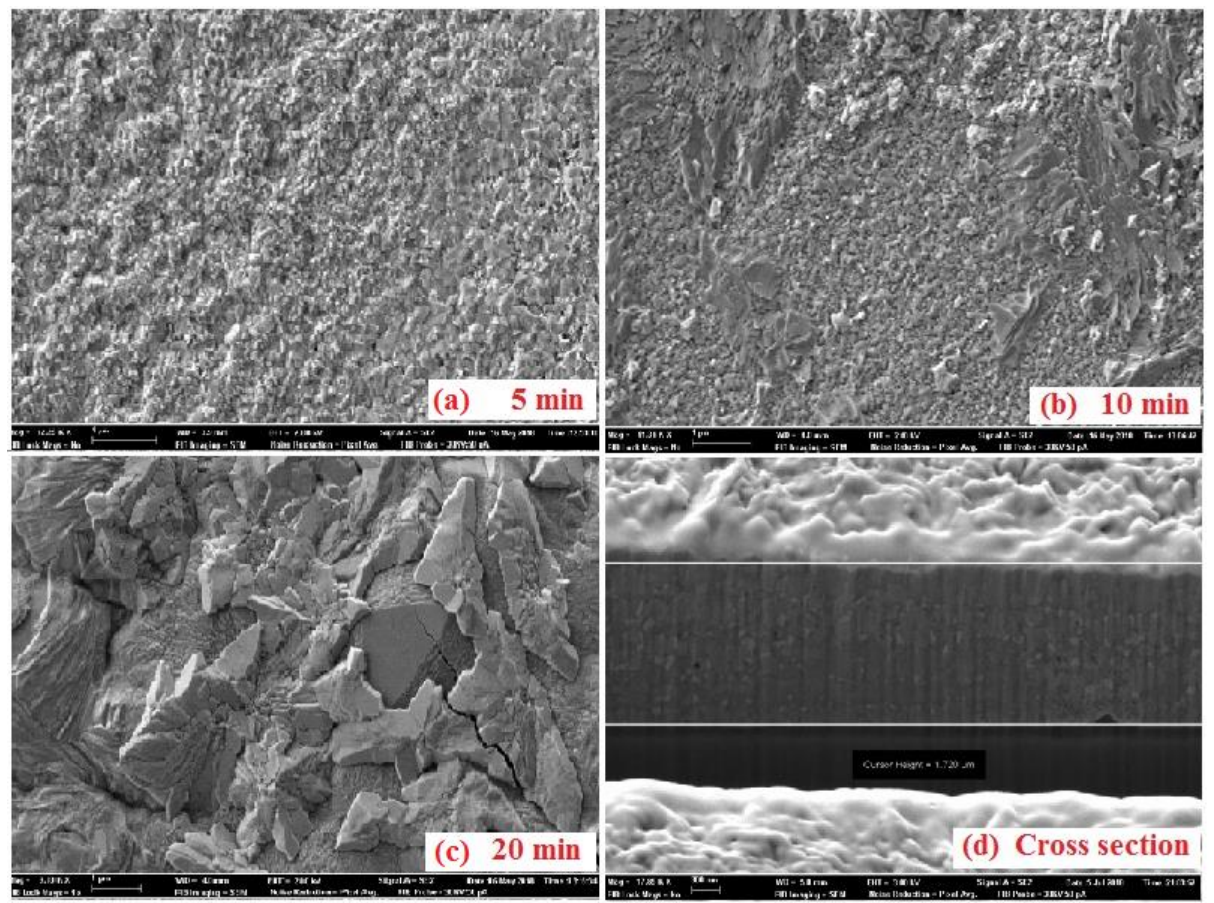

Figure 4.7. SEM images with different annealing time (a) CIGS1 for 5min, (b) CIGS2 for $10 \mathrm{~min}$, (c) CIGS3 for $20 \mathrm{~min}$ and (d) Cross Section for CIGS $20 \mathrm{~min}$.

\subsubsection{TEM analysis of (CIGS) thin films grown by Spray pyrolysis}

Transmission electron microscopy is a direct method to have direct access to the size and shape of grains as well as the polydispersity of nanocrystals [10] the images took by Transmission electron microscopy shows that inter-plane distance of the grains is becoming larger with the duration of surface treatment of the thin layers prepared by spray pyrolysis. The surface treatment time $5 \mathrm{~min}, 10$ min and $20 \mathrm{~min}$ of the samples increases the inter planer distance of the samples $0.25 \mathrm{~nm}, 0.28 \mathrm{~nm}$ and $0.36 \mathrm{~nm}$ respectively. (figure 4.8 ) 

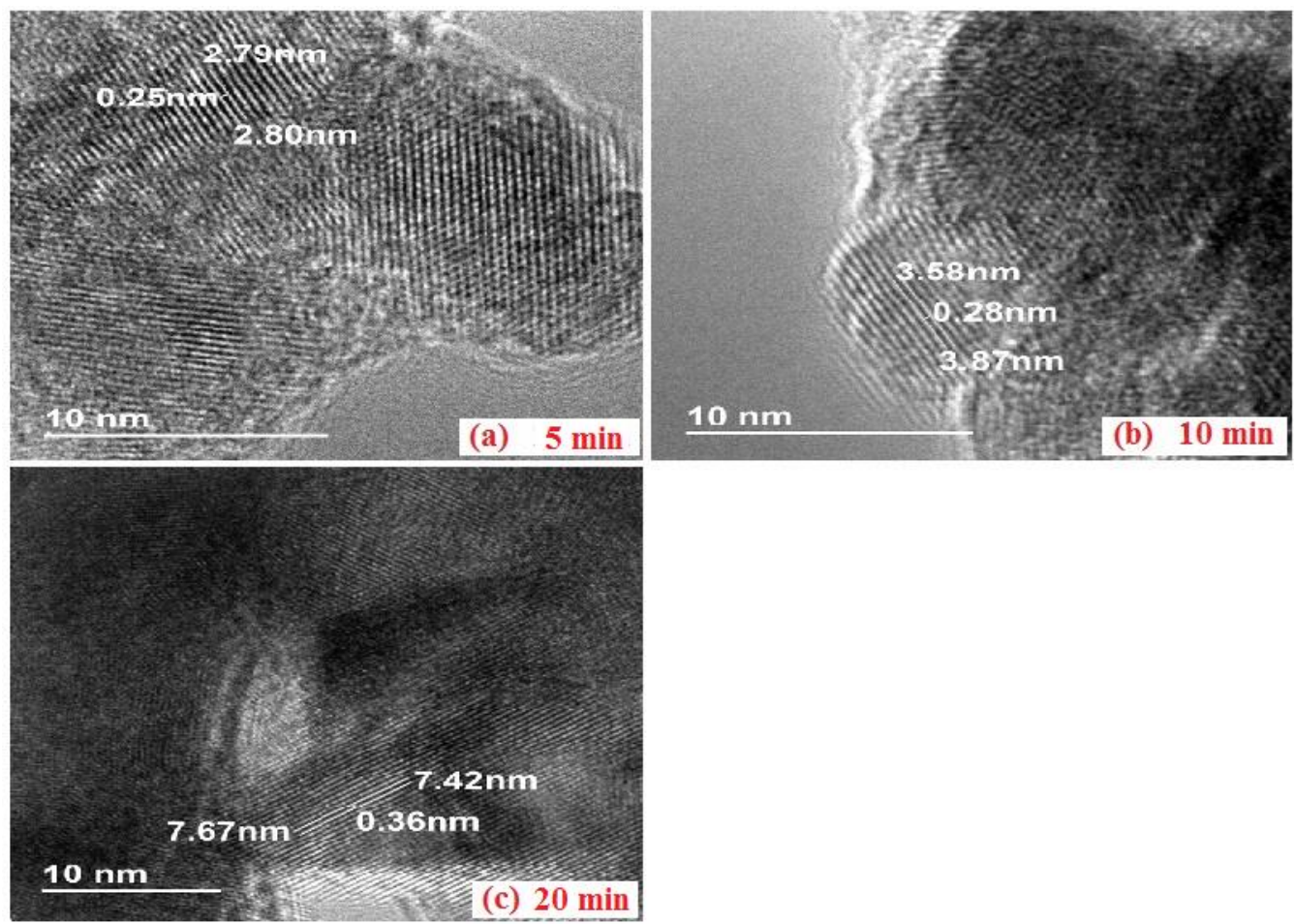

Figure.4.8. TEM images (a) CIGS1 for 5 min, (b) CIGS2 for 10 min and (c) CIGS3 for $20 \mathrm{~min}$.

\subsubsection{AFM analysis of (CIGS) thin films grown by Spray pyrolysis}

Figure 4.9 shows 2D and 3D surface topography with difference in roughness and grain size of the films [11]. According to AFM analysis annealing time effect the roughness and the grain size of the samples which illustrate in table 4.5. The grain boundaries of the films become low due to increasing of the grain size to reduce the recombination rate and increase the device performance, which is favorable for the performance of solar cells as the roughness increases to trap lighter. 

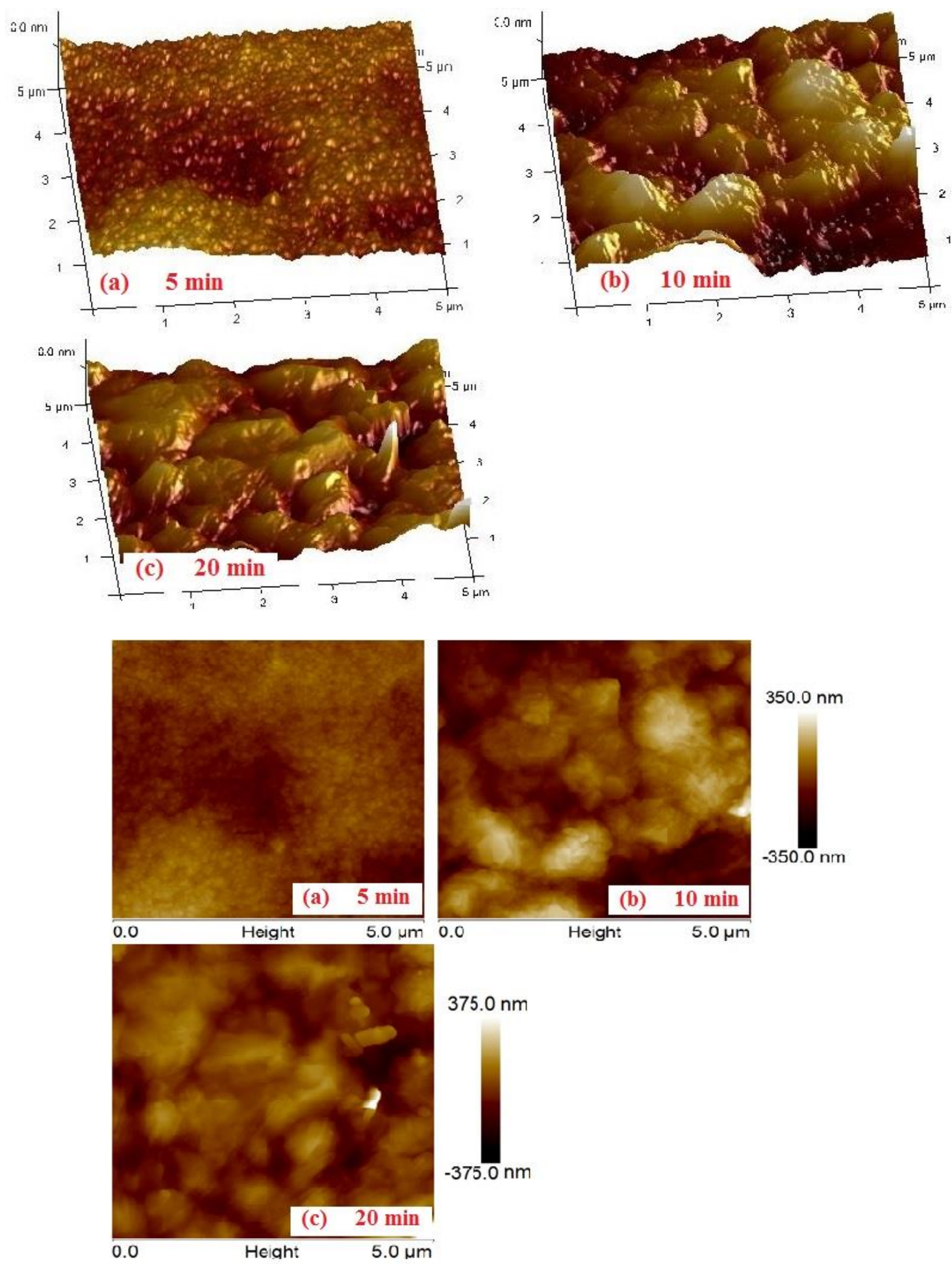

$375.0 \mathrm{~nm}$

$-375.0 \mathrm{~nm}$

Figure. 4.9 2D and 3D AFM images of CIGS thin films (a) CIGS1 5 min, (b) CIGS2 10 min and (c) CIGS3 $20 \mathrm{~min}$. 
Table 4.5: Roughness and Grain Size of CIGS thin films prepared by Spray pyrolysis.

\begin{tabular}{|c|c|c|}
\hline Sample ID & Roughness (nm) & Grain Size (nm) \\
\hline Sparyed-CIGS1 5min & 318 & 429.82 \\
\hline Sprayed-CIGS2 10min & 490 & 546.26 \\
\hline Sprayed-CIGS3 20min & 751 & 567.22 \\
\hline
\end{tabular}

\subsubsection{Absorbance, transmittance and gap energy:}

Annealing temperature and annealing time have an impact on the optical properties and the optical constants which are very important for the efficiency of a semiconductor [13]. The absorbance figure 4.10 shows that absorption for the sprayed CIGS3 sample treated at a $370{ }^{\circ} \mathrm{C}$ temperature for $20 \mathrm{~min}$ and it has been recorded in the wavelength range (400 $\mathrm{nm}$ to $900 \mathrm{~nm}$ ). It is found that all the films have a high absorbance and a low transmittance. There is a small difference in the results in terms of percentage $(\%)$ of the absorbance and transmittance of the films. The highest transmittance value is observed for the CIGS1 sprayed (25\%) with annealing for $5 \mathrm{~min}$ and the CIGS3 film with a lower transparency of $10 \%$ figure 4.11 . The data reveal that increase in an absorption and decrease in transmission with annealing time is related to improving grain size and roughness of the samples. The roughness of the surface is played an important role to absorb more light and cause to improve the performance of the device. 


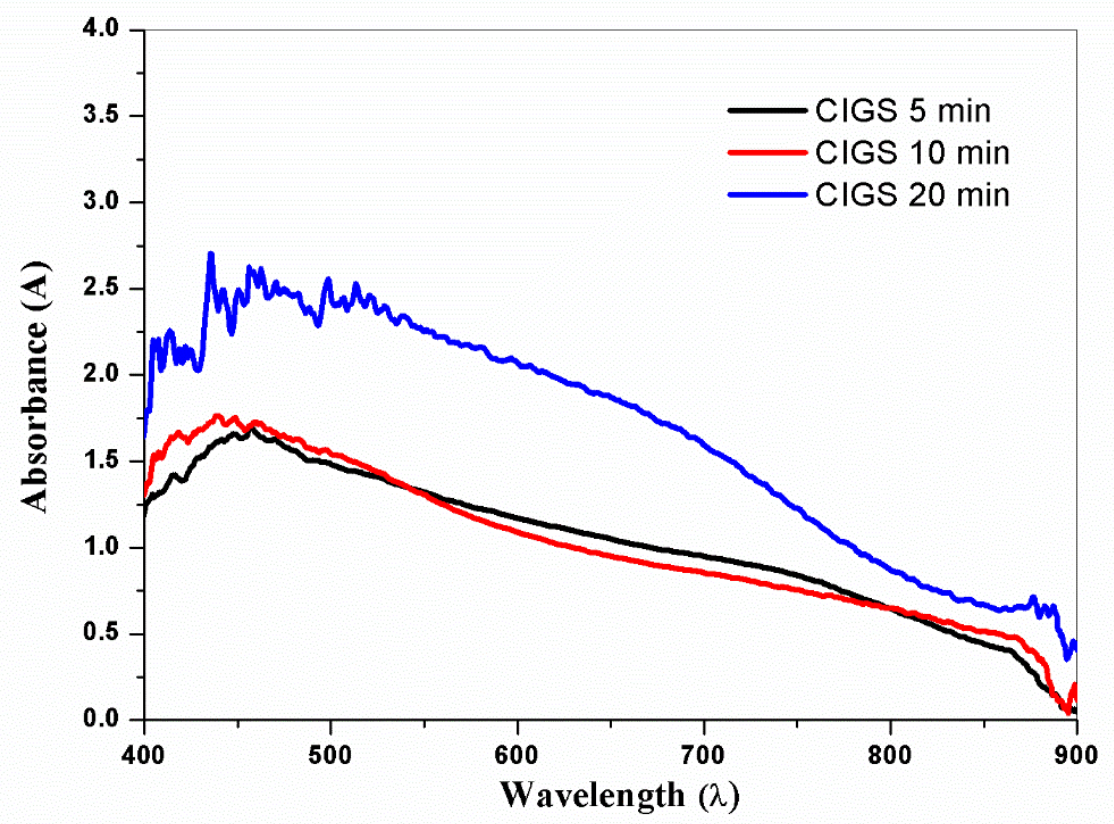

Figure. 4.10. Optical absorbance of the CIGS thin films obtained by spray with annealing.

By processing the slaps at a temperature $370{ }^{\circ} \mathrm{C}$ for $20 \mathrm{~min}$ this shows high absorbance in the visible region with a maximum value of about $1.15 \%$.

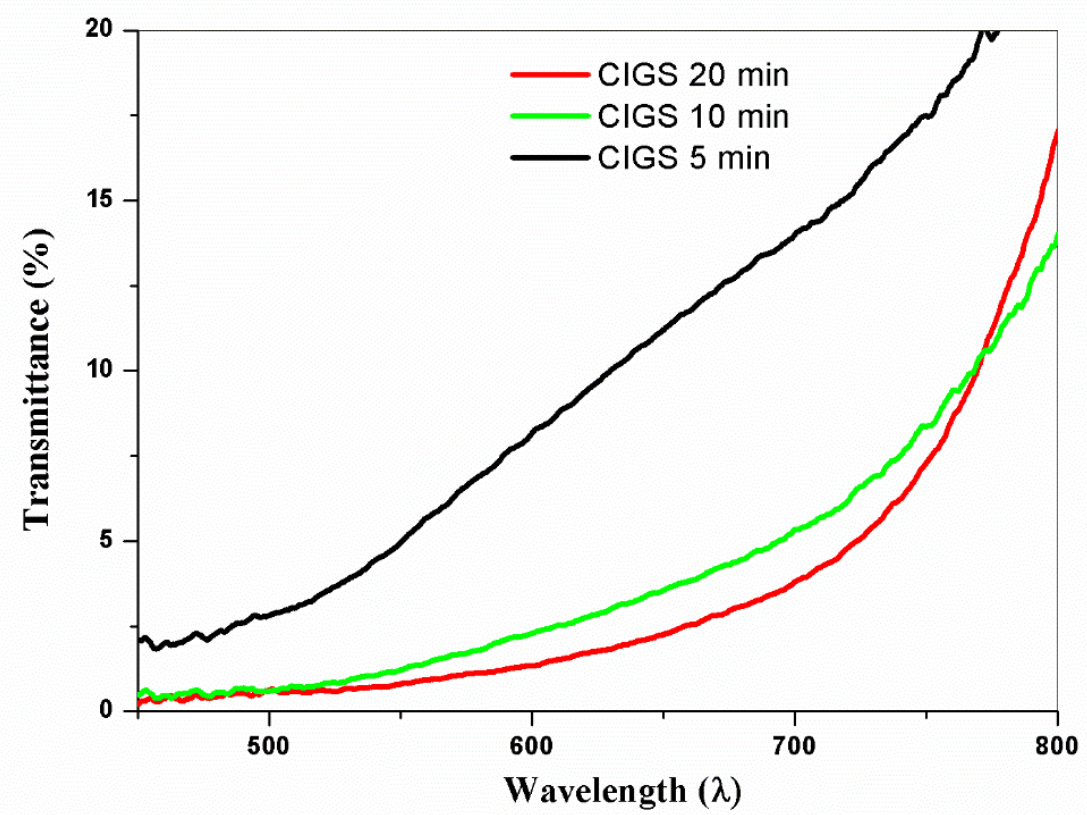

Figure. 4.11. Optical transmittance of the CIGS thin films. 
To calculate the gap energy of the thin films prepared we use the following equation 4.14 and 4.15 and it conclude from the linear diagram of $(\alpha h v)^{2}$ versus hv [14].

$$
(\alpha h v)^{2}=\mathrm{B}\left(\mathrm{hv}-\mathrm{E}_{\mathrm{g}}\right)
$$

where $\alpha$ is absorption coefficient and its calculated by equation (4.14), $\mathrm{h}$ is Planck constant, B is a constant, $\mathrm{E}_{\mathrm{g}}$ is the band gap energy and $\mathrm{t}$ is the thickness of the thin films.

$$
\alpha=\frac{1}{\mathrm{t}} \ln \left(\frac{1}{\mathrm{~T}}\right)
$$

The calculated values of band gap energy are $1.66 \mathrm{eV}$ for sample sprayed CIGS1, $1.62 \mathrm{eV}$ for Sprayed CIGS2 figure 4.12. For sample Sprayed CIGS3, a strong absorbance and band gap energy of the order of $1.46 \mathrm{eV}$ make the films annealed at $370{ }^{\circ} \mathrm{C}$ for $20 \mathrm{~min}$ is good choice for photovoltaic application.

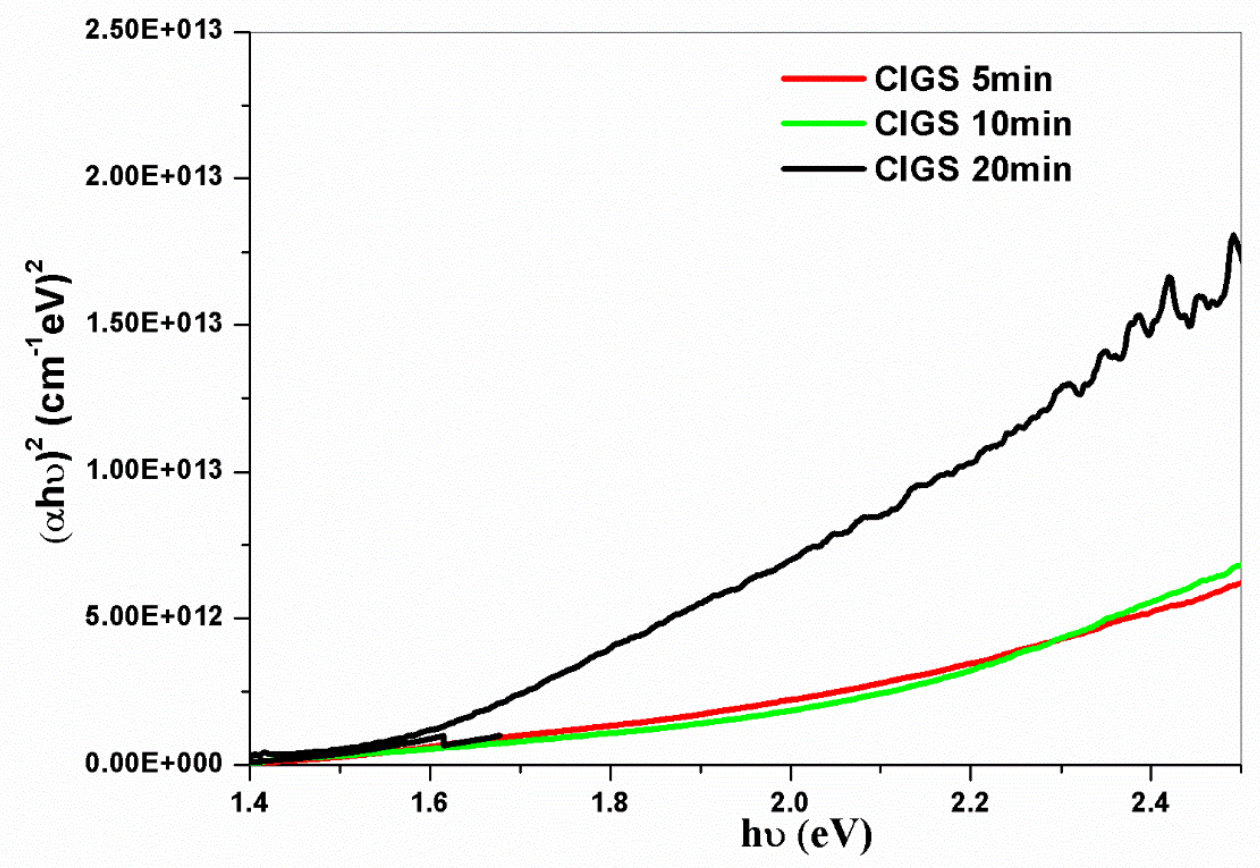

Figure.4.12. Optical absorbance of the CIGS thin films.

\subsubsection{Optical constants:}

The optical constants, namely refractive index (n), extinction coefficient $(\mathrm{k})$, real part $\left(\varepsilon_{\mathrm{r}}\right)$ and imaginary part $\left(\varepsilon_{\mathrm{i}}\right)$ of dielectric constant for CIGS, which were calculated using Eqs (4.16), (4.17), (4.18) and (4.19) whose values are presented in Table 4.6 [16]. 


$$
\begin{aligned}
\mathrm{n} & =\left(\frac{1+\mathrm{R}}{1-\mathrm{R}}\right)+\sqrt{\frac{4 \mathrm{R}}{(1-\mathrm{R})^{2}}-\mathrm{k}^{2}} \\
\mathrm{~K} & =\frac{\alpha \lambda}{4 \Pi} \\
\varepsilon_{\mathrm{r}} & =\mathrm{n}^{2}-\mathrm{k}^{2} \\
\varepsilon_{\mathrm{i}} & =2 n k
\end{aligned}
$$

Where $\mathrm{n}$ is the refractive index, $\mathrm{k}$ is the extinction coefficient, $\lambda$ is the wavelength, $\alpha$ is the absorption coefficient and $\mathrm{R}$ is the reflectance of the films. The value of refractive index for the films spayed is attributed to the thickness of the films. The high extinction coefficient value is observed for this sprayed CIGS3 due to the high absorption into this film compared to the other samples. The high extinction coefficient values are attributed to the high absorbance of CIGS3. The both real and imaginary part of dielectric constant decrease with the wavelength and the maximum values are observed on the sample sprayed CIGS3.

Table 4.6 Optical properties of the CIGS thin films.

\begin{tabular}{|l|l|l|l|l|}
\hline \multicolumn{1}{|c|}{ Precursor } & $\mathbf{n}$ & $\mathbf{k}$ & $\boldsymbol{\varepsilon}_{\mathrm{r}}$ & $\boldsymbol{\varepsilon}_{\mathrm{i}}$ \\
\hline Sprayed CIGS1-5min & 4 & $\mathbf{0 . 0 3}$ & 12.5 & $\mathbf{0 . 2 5}$ \\
\hline Sprayed CIGS2-10min & 4 & $\mathbf{0 . 0 3}$ & 12.5 & $\mathbf{0 . 2 5}$ \\
\hline Sprayed CIGS3-20min & 5 & $\mathbf{0 . 0 4}$ & 14 & 0.37 \\
\hline
\end{tabular}

\subsection{Electrical properties}

Hall effect measurements gave us several information on electrical properties. we used four prob methods to give electrical resistance using the equation 4.20 below.

$$
\mathrm{R}=\mathrm{R}_{\mathrm{s}} \mathrm{xt}
$$

Where $t$ is the thickness and $\mathrm{R}_{\mathrm{s}}$ is the resistivity of the thin film.

The resistivity of the three thin layers is of the order of $10^{-2}(\Omega . \mathrm{cm})$, the lowest is observed resistivity values for the layers are annealed and the resistivity it is in order of $0.65(\Omega \mathrm{cm})$ for all samples. The values obtained by the reported in table 4.7. The low values of resistivity are attributed to the electrical nature of CIGS semiconductors. The concentration and mobility of the charge carriers in the CIGS layers are determined by Hall effect measurements [17]. The measurements made by the Hall effect allowed us to determine the resistivity $\left(R_{s}\right)$ where we found that it is the order of $10^{-2} \Omega . c m$ 
and the mobility $(\mu)$ is of the order $10^{2} \mathrm{~cm}^{2} / \mathrm{V} \mathrm{s}$ and for the concentration in carriers $(\mathrm{n})$ is the order $10^{6} 1 / \mathrm{cm}^{3}$ The mobility $\left(\mu_{\mathrm{n}}\right)$ and the concentration $(\mathrm{n})$ of the charge carriers are listed in table.

Table 4.7: Electrical properties of the CIGS thin films calculated using Van der pauw method.

\begin{tabular}{|c|c|c|c|c|c|}
\hline Sample & $\begin{array}{l}\text { Concentration } \\
\left(1 / \mathrm{cm}^{3)}\right.\end{array}$ & $\operatorname{Rs}(\Omega / s q)$ & 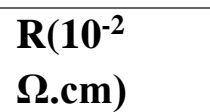 & $\begin{array}{r}\text { Conductivity } \\
(1 / \Omega . c m)\end{array}$ & $\begin{array}{l}\text { Mobility } \\
\qquad\left(\mathrm{Cm}^{2} / \mathrm{V} \mathrm{s}\right)\end{array}$ \\
\hline CIGS1-5 min & $1.5 \mathrm{E}+15$ & 404.40 & 606.60 & $2.5 \mathrm{E}+15$ & $6.87 \mathrm{E}+2$ \\
\hline CIGS2-10 min & $1.1 \mathrm{E}+16$ & 434.07 & 651.01 & 3.8 E+15 & $7.98 \mathrm{E}+1$ \\
\hline CIGS3-20 min & $1.2 \mathrm{E}+16$ & 435.01 & 652.60 & $0.8 \mathrm{E}+15$ & $8.74 \mathrm{E}+1$ \\
\hline
\end{tabular}

The CIGS thin films were prepared and deposited by spray technique and treated with a $370{ }^{\circ} \mathrm{C}$ annealing temperature at different annealing times. Thin films have been studied using several characterization techniques such as X-ray diffraction to calculate the lattice parameters effective lattice strain and Dislocation density. Scanning electron microscopy (SEM) shows that the surface is with a noticeable difference in grain size. Transmission electron microscopy (TEM) results is confirming strong relation that films are polycrystalline.

Atomic force microscopy (AFM) shows outstanding relation with the grain size and roughness of the surface of the films. The high absorbance and low transmittance are observed for the films prepared with a band gap energy of approximately $1.46 \mathrm{eV}$. Optical constants such as refractive index

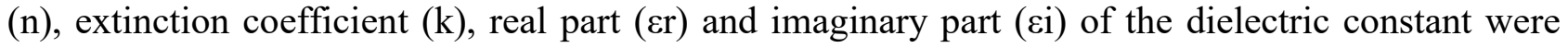
extracted by Absorbance / transmittance data.

The carrier concentration, the mobility, resistivity and conductivity for the films treated at a 370 ${ }^{\circ} \mathrm{C}$ time for 20 minutes are $1.2 \mathrm{E}+161 / \mathrm{cm}^{3}, 652.6010^{-2} \Omega . \mathrm{cm}, 0.8 \mathrm{E}+151 / \Omega . \mathrm{cm}, 8.74 \mathrm{E}+1 \mathrm{~cm}^{2} / \mathrm{V} \mathrm{s}$ respectively. By considering the values found for the electrical properties, it is proposed that the annealing time of 20 min under a temperature of $370{ }^{\circ} \mathrm{C}$ is the right choice for the CIGS based solar cells.

\section{Simulation performance of CIGS grown by Spray pyrolysis technique}

Solar Cell Capacitance Simulator (SCAPS) is a one-dimensional solar cell simulation program. This program was developed to simulate the AC and DC characteristics of thin-film heterojunction solar cells. Among the main features of SCAPS version 3.2.00 is that it incorporates Gaussian-like defect levels as well. Output parameters such as JV characteristics in the dark and under illumination can be obtained from the results from SCAPS simulation. 
In addition to important information about the characteristics of thin layers, such as the energy band diagram, electric field distributions, free and trapped carrier populations, generation recombination profiles and carrier density of individual carriers, the position function can also be extracted from the SCAPS program. SCAPS software allows solving the equations of a single semiconductor variable, such as the Poisson equation 4.20 and the continuity equations for holes and electrons $[18,19]$.

$$
\frac{d^{2}}{d x^{2}} \Psi(x)=\frac{e}{\varepsilon_{0} \varepsilon_{r}}\left(p(x)-n(x)+N_{D}-N_{A}+\rho_{p}-\rho_{n}\right)
$$

where $\psi$ is the electrostatic potential, e is electrical charge, $\varepsilon_{\mathrm{r}}$ and $\varepsilon_{0}$ are the relative and vacuum permittivity, $\mathrm{p}$ and $\mathrm{n}$ are hole and electron concentrations, $\mathrm{N}_{\mathrm{D}}$ and $\mathrm{N}_{\mathrm{A}}$ are the charge impurities of donor and acceptor type, and $\rho_{\mathrm{p}}$ and $\rho_{\mathrm{n}}$ are holes and electrons distribution.

The continuity equations for electrons and holes are 4.21 and 4.22:

$$
\begin{aligned}
& \frac{d j n}{d x}=G-R \\
& \frac{d j p}{d x}=G-R
\end{aligned}
$$

The structure composed of MO / CIGS / CdS / i-ZnO /ZnO: Al was adopted in this study, where Mo plays the role of back contact, CIGS is the absorbing layer, CdS is the buffer layer and i-ZnO and $\mathrm{ZnO}: \mathrm{Al}$ are the windows layers.

By incorporating the different material parameters into SCAPS for all aspects of the analysis, one can observe and record the variations in the values of Jsc, Voc, FF and thus of the efficiency. The performance of solar cells is analyzed via its $\mathrm{J}-\mathrm{V}$ characteristics and quantum efficiency. The parameters of the materials used in this simulation that have been selected on the basis of experimental values, theory [20] and in some cases reasonably estimated are listed in Table 4.8.

Table 4.8. The parameters of the materials used for the simulation.

\begin{tabular}{|c|c|c|c|c|}
\hline Layer & ZnO:Al & i-ZnO & CdS & CIGS \\
\hline Thickness $(\mu \mathrm{m})$ & 0.45 & 0.08 & 0.05 & 2.2 \\
\hline Bandgap $(\mathrm{eV})$ & 3.3 & 3.3 & 2.41 & 1.9 \\
\hline Electron affinity $(\mathrm{eV})$ & 4.4 & 4.4 & 4.5 & 4.5 \\
\hline
\end{tabular}




\begin{tabular}{|c|c|c|c|c|}
\hline Dielectric permittivity & 9 & 9 & 9 & 10 \\
\hline CB effective density of states $\left(1 / \mathrm{cm}^{3}\right)$ & $2.2 \times 10^{18}$ & $2.2 \times 10^{18}$ & $1.8 \times 10^{19}$ & $2.2 \times 10^{18}$ \\
\hline VB effective density of states $\left(1 / \mathrm{cm}^{3}\right)$ & $2.2 \times 10^{19}$ & $1.8 \times 10^{19}$ & $2.4 \times 10^{18}$ & $1.8 \times 10^{19}$ \\
\hline Electron thermal velocity $(\mathrm{cm} / \mathrm{s})$ & $1 \times 10^{7}$ & $1 \times 10^{7}$ & $1 \times 10^{7}$ & $1 \times 10^{7}$ \\
\hline Hole thermal velocity $(\mathrm{cm} / \mathrm{s})$ & $1 \times 10^{7}$ & $1 \times 10^{7}$ & $1 \times 10^{7}$ & $1 \times 10^{7}$ \\
\hline Electron mobility $\left(\mathrm{cm}^{2} / \mathrm{Vs}\right)$ & 100 & 100 & 35 & 100 \\
\hline Hole mobility $\left(\mathrm{cm}^{2} / \mathrm{Vs}\right)$ & 25 & 25 & 50 & 25 \\
\hline $\begin{array}{l}\text { Shallow uniform donor density ND } \\
\qquad\left(1 / \mathrm{cm}^{3}\right)\end{array}$ & $1 \times 10^{20}$ & $1 \times 10^{18}$ & $1 \times 10^{17}$ & 10 \\
\hline $\begin{array}{l}\text { Shallow acceptor density NA(x) } \\
\left(1 / \mathbf{c m}^{3}\right)\end{array}$ & $\mathbf{0}$ & $\mathbf{0}$ & $\mathbf{0}$ & $2 \times 10^{14}$ \\
\hline
\end{tabular}

\subsection{Simulation of the performance of CIGS grown by spray pyrolysis technique}

The curve of the resulting $\mathrm{J}-\mathrm{V}$ characteristic of the simulation using the values of Table 4.8 is shown in Figure 4.13. The efficiency of this solar cell is $24.55 \%$, which is not very different from that of a practical CIGS solar cell [21]. This shows that our solar cell model is valid and reliable to get an idea of the effect of various parameters on the efficiency of the solar cells
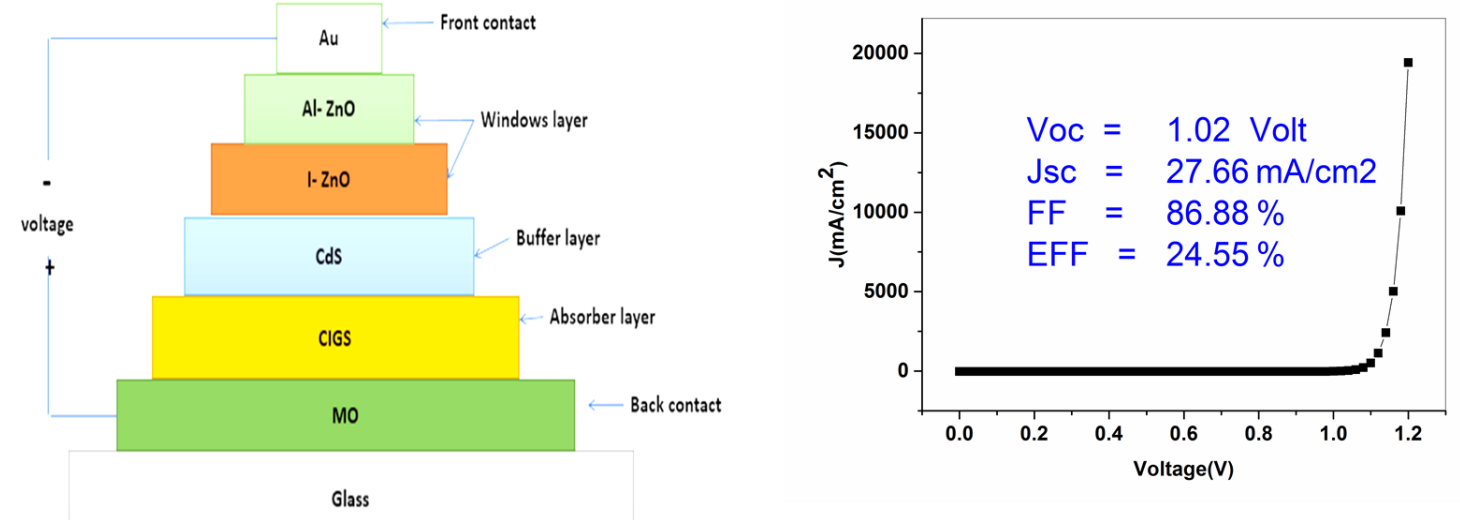

Figure 4.13. structure of the $\mathrm{Cu}-\mathrm{In}-\mathrm{Ga}-\mathrm{S}$, Se (CIGS) solar cell and Performance of CIGS solar cells.

\subsubsection{Effect of the band gap}


We evaluated the impact of different gap energies of the CIGS absorber layer on cell performance. The gap energy has been varied from $1.1 \mathrm{eV}$ to $1.7 \mathrm{eV}$ in steps of $0.1 \mathrm{eV}$ and we can observe the changes in the values of Jsc, Voc, FF and the efficiency in Figure 4.14. Jsc decreases linearly. This decrease can be explained by the fact that broadband absorbers do not absorb photons at long wavelengths. We observe a small amount of generated electron-hole pairs and, therefore, a small number of free carriers collected, which could reduce the value of Jsc. The decrease in efficiency after $1.5 \mathrm{eV}$ is due to the decay of Jsc, because Voc and FF grow substantially to $1.5 \mathrm{eV}$ and then remain almost unchanged.
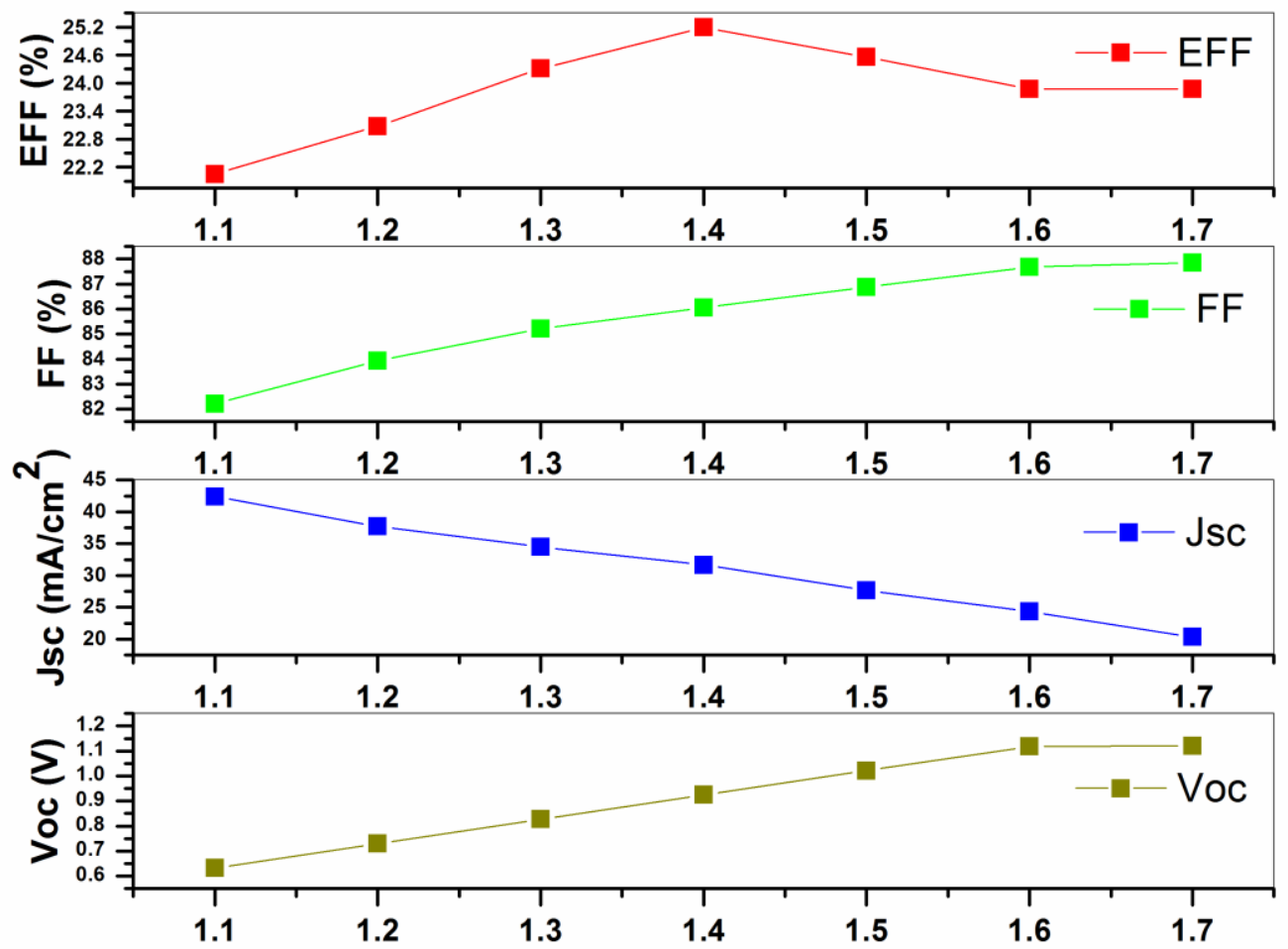

$\mathrm{Eg}(\mathrm{eV})$

Figure 4.14 The output data of the solar cell (short-circuit current density Jsc, open-circuit voltage Voc, fill factor FF and efficiency EFF) depending on gap energy of the CIGS p-layer.

\subsubsection{Effect of thickness on the performance of the CIGS cell}

The effect of the thickness of the CIGS absorbent layer on cell performance was investigated by varying it from $2 \mu \mathrm{m}$ to $5 \mu \mathrm{m}$ while other parameters were kept constant. Figure 13 shows the effects of this variation on cell performance parameters, such as short-circuit current density (JSC), open- 
circuit voltage (Voc), form factor (FF), and efficiency. It can be seen in Figure 4.15 that Jsc and Voc grow substantially with the increasing thickness of the absorbent layer. This could be due to the fact that more photons with long wavelengths are absorbed by the absorber when it is wider and thus a larger number of electron-hole pairs is observed. This will produce improvements in the values of Jsc and Voc and, thus, in efficiency [22].

Note that FF remains almost stable after $2.5 \mu \mathrm{m}$. Larger thicknesses introduce resistive components that can affect the form factor. It is also noted that the variation in the value of the yield is insignificant when the thickness varies from $2.5 \mu \mathrm{m}$ to $5 \mu \mathrm{m}$; it is therefore not necessary to produce CIGS solar cells of very great thickness that it will be just a loss of composite materials because it is necessary to establish a compromise between the efficiency of the cell and the cost of mass production.
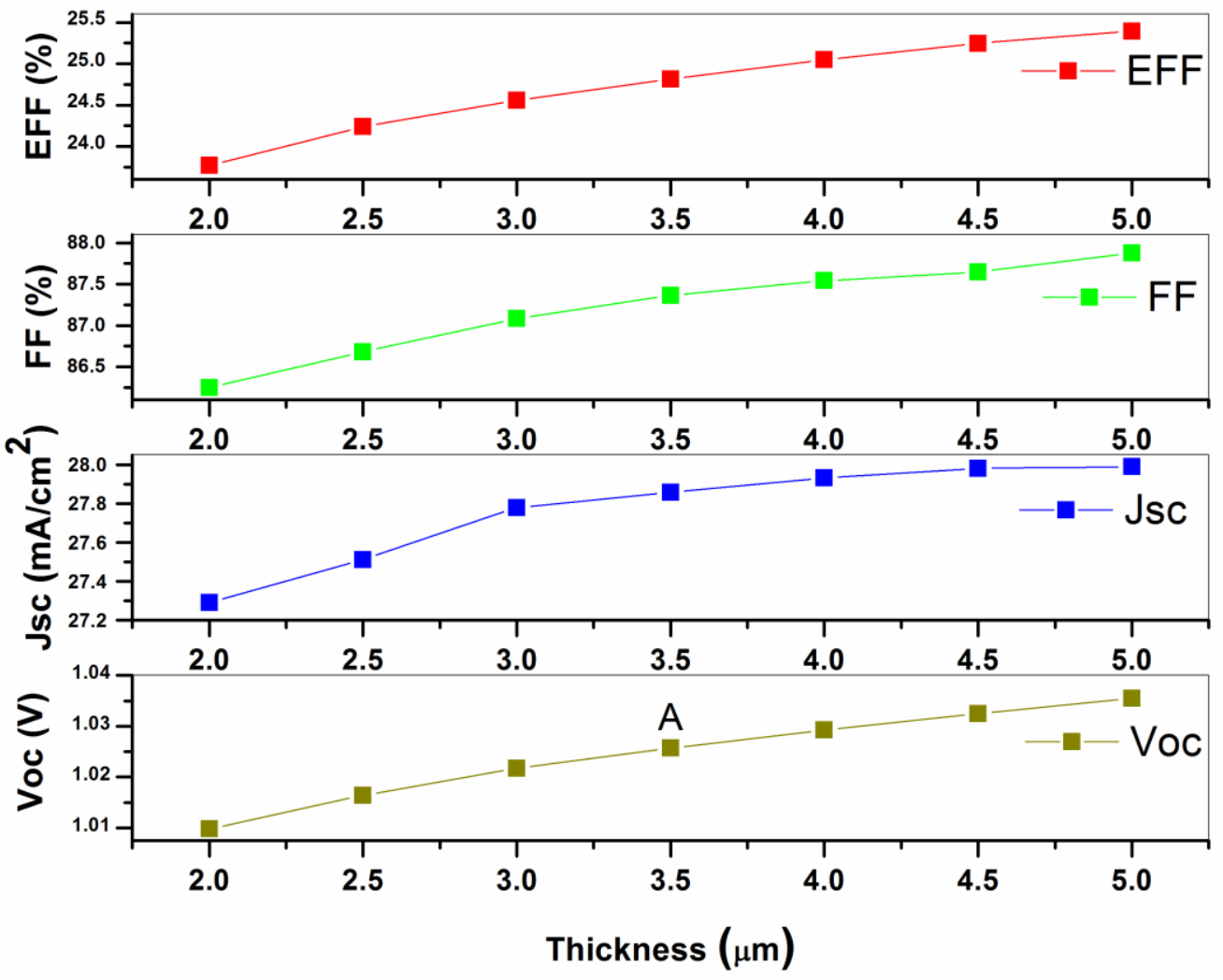

Figure 4.15. The output data of the solar cell (short-circuit current density Jsc, open-circuit voltage Voc, fill factor FF and efficiency EFF) depending on the thickness of the CIGS p-layer.

\subsubsection{Effects of operating temperature on the performance of CIGS solar cells}


The influence of temperature on the performance parameters of the CIGS solar cell has been studied for temperatures ranging from 300 to $400 \mathrm{~K}$ in steps of $25 \mathrm{~K}$. As can be seen in the figure 4.16, the values of Voc, FF and the efficiency decreases sharply with increasing temperature while Jsc increases slightly with it. As the temperature increases, the electrons in the cell gain more energy and become less stable and they cannot recombine with the holes before reaching the charging zone. This decreases the values of Voc and FF and the efficiency is negatively affected.

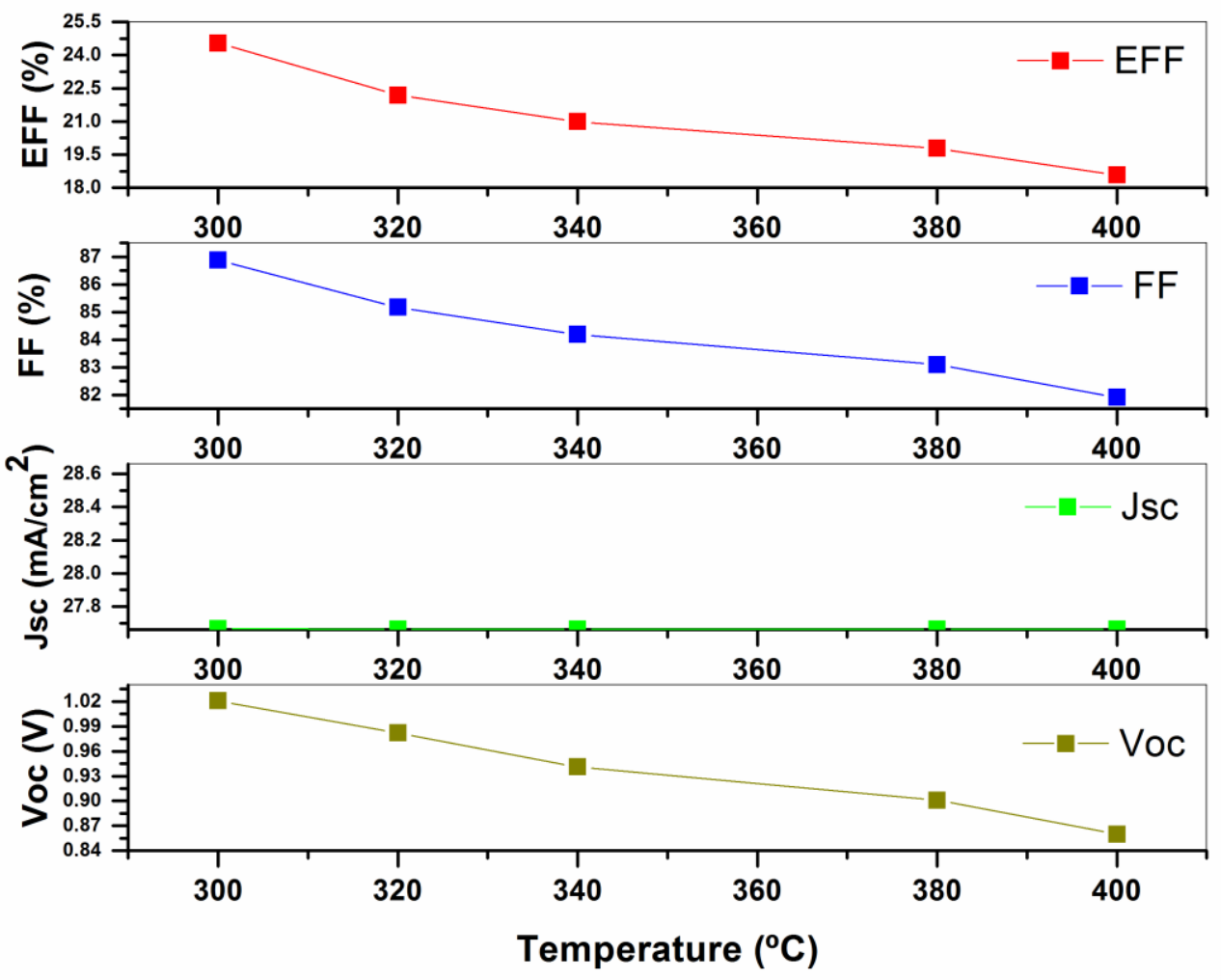

Figure 4.16 The output data of the solar cell (short-circuit current density Jsc, open-circuit voltage Voc, fill factor FF and efficiency EFF) depending on temperature of the CIGS p-layer.

\subsubsection{Effect of shallow acceptor density on the performance of the CIGS cell}

The value of $\mathrm{N}_{\mathrm{A}}$ is one of the most important values for any pn junction device because it governs the specifications of the device and it is preferable if one wants to obtain relevant simulation results as well as an effective solar cell. Figure 4.17 shows that Voc increases with carrier density while Jsc decreases with carrier density. This is probably due to the fact that recombination phenomenon is increased by increasing the density of the carriers. This can reduce the possibility of collecting free electrons generated by the incident radiation on the front contact and thus contribute to lowering the 
value of Jsc. As carrier concentration increases in the absorber layer, the semiconductor becomes degenerate, thus limiting large $\mathrm{N}_{\mathrm{A}}$ values, since the solar cell is facing different climatic conditions.
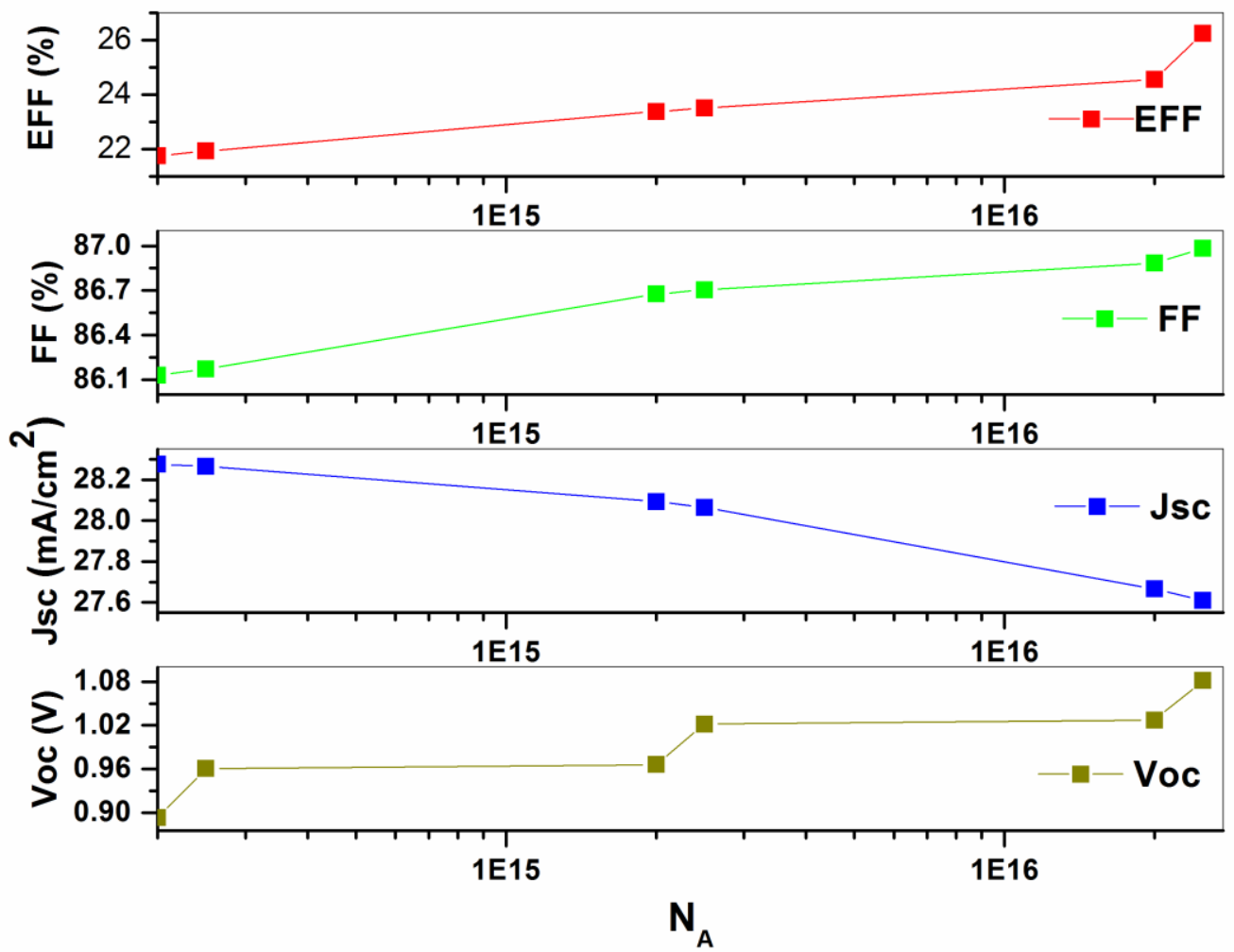

Figure 4.17 The output data of the solar cell (short-circuit current density Jsc, open-circuit voltage Voc, fill factor FF and efficiency EFF) depending on $\mathrm{N}_{\mathrm{A}}$ of the CIGS p-layer.

\section{Conclusions}

The performance of the cell is analyzed and simulated by the function of the characteristics of the absorbent layer elaborated as thickness, energy gap, $\mathrm{N}_{\mathrm{A}}$ and also by the effect of temperature. The optimal thickness of the absorbent layer CIGS with CdS buffer layer are in the range of $2000 \mathrm{~nm}$ to $3000 \mathrm{~nm}$. Moreover, according to the results of the simulation, the solar cell performance is negatively affected by the increase of the operating temperature. 


\section{References:}

[1] T.A. Reese, S.B. Schujman, R.J. Matyi, Structure evolution in CIGS deposition: An X-ray diffraction analysis with Rietveld whole-pattern refinement. In Photovoltaic Specialist Conference (PVSC), (2014) IEEE 40th 1691-1695.

[2] U.C. Matur, S. Akyol, N. Baydoğan, H. Cimenoglu, The Optical Properties of CIGS Thin Films Derived by Sol-gel Dip Coating Process at Different Withdrawal Speed. Procedia-Social and Behavioral Sciences, 195 (2015) 1762-1767.

[3 ] M.B. Rabeh, N. Khedmi, M.A. Fodha, M. Kanzari, the effect of thickness on optical band gap and N-type conductivity of CuInS2 thin films annealed in air atmosphere. Energy Procedia, 44 (2014) 52-60.

[4 ] Bouich, A., et al. "Investigation of the optical properties of CuIn (Se, S) 2 thin films for photovoltaic application." Materials Today: Proceedings 13 (2019): 663-669..

[5] B. Xu, X. Li, Z. Qin, C. Long, D. Yang, J. Sun, L. Yi, Electronic and optical properties of CuGaS2: First-principles calculations. Physica B: Condensed Matter, 406 (2011) 946-951.

[6] Kumar, Y. K., Babu, G. S., Bhaskar, P. U., \& Raja, V. S. (2009). Effect of starting-solution pH on the growth of $\mathrm{Cu} 2 \mathrm{ZnSnS} 4$ thin films deposited by spray pyrolysis. physica status solidi (a), 206(7), 1525-1530.

[7] Ajili, M., Castagné, M., \& Turki, N. K. (2014). Characteristics of CuIn1-xGaxS2 thin films synthesized by chemical spray pyrolysis. Journal of Luminescence, 150, 1-7.

[8] Babu, B. J., Velumani, S., Kassiba, A., Asomoza, R., Chavez-Carvayar, J. A., \& Yi, J. (2015). Deposition and characterization of graded $\mathrm{Cu}$ (In1-xGax) Se2 thin films by spray pyrolysis. Materials Chemistry and Physics, 162, 59-68.

[9] Varol, S. F., Babür, G., Çankaya, G., \& Kölemen, U. (2014). Synthesis of sol-gel derived nanocrystalline $\mathrm{ZnO}$ thin films as TCO window layer: effect of sol aging and boron. RSC Advances, 4(100), 56645-56653.

[10] Frantz, J. A., Bekele, R. Y., Nguyen, V. Q., Sanghera, J. S., Bruce, A., Frolov, S. V., ... \& Aggarwal, I. D. (2011). Cu (In, Ga) Se2 thin films and devices sputtered from a single target without additional selenization. Thin Solid Films, 519(22), 7763-7765.

[11] Calderón, C., Gordillo, G., Bartolo-Pérez, P., \& Mesa, F. (2007). Effect of the deposition conditions on the optical, morphological and compositional properties of CuIn1- xGaxSe 2 thin films prepared by a multistage process. Revista Mexicana de Física, 53(7), 270-273. 
[12] Schmid, D., Ruckh, M., Grunwald, F., \& Schock, H. W. (1993). Chalcopyrite/defect chalcopyrite heterojunctions on the basis of CuInSe2. Journal of Applied Physics, 73(6), 2902-2909.

[13] Matur, U. C., Akyol, S., Baydoğan, N., \& Cimenoglu, H. (2015). The Optical Properties of CIGS Thin Films Derived by Sol-gel Dip Coating Process at Different Withdrawal Speed. Procedia-Social and Behavioral Sciences, 195, 1762-1767.

[14] Pankove, J. I. (1975). Optical processes in semiconductors. Courier Corporation.

[15] Matsumura, K., Fujita, T., Itoh, H., \& Fujita, D. (2014). Characterization of carrier concentration in CIGS solar cells by scanning capacitance microscopy. Measurement Science and Technology, 25(4), 044020.

[16] H. Movla, Optimization of the CIGS based thin film solar cells: Numerical simulation and analysis. Optik-International Journal for Light and Electron Optics, 125(2014) 67-70.

[17] M. Mostefaoui, H. Mazari, S. Khelifi, A. Bouraiou, R. Dabou, Simulation of High Efficiency CIGS solar cells with SCAPS-1D software. Energy Procedia, 74 (2015) 736-744.

[18] Prabhakar, Rajiv Ramanujam, et al. "Facile water-based spray pyrolysis of earth-abundant $\mathrm{Cu} 2 \mathrm{FeSnS} 4$ thin films as an efficient counter electrode in dye-sensitized solar cells." ACS applied materials \& interfaces 6.20 (2014): 17661-17667.

[ 19] M. Powalla, S. Paetel, D. Hariskos, R. Wuerz, F. Kessler, P. Lechner, W. Wischmann, T.M. Friedlmeier, Advances in Cost-Efficient Thin-Film Photovoltaics Based on $\mathrm{Cu}$ (In, Ga) Se2. Engineering, 3 (2017) 445-451.

[20] P. Chelvanathan, M.I. Hossain, N. Amin, Performance analysis of copper-indium-galliumdiselenide (CIGS) solar cells with various buffer layers by SCAPS. Current Applied Physics, 10 (2010) S387-S391. 


\section{Chapter V}

\section{Manufacture of CdZnS/CdS/CIGS/Mo solar cells performance.}

\section{Contents}

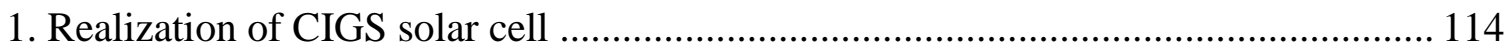

2. Structural and morphology of CdS buffer layer and CIGS absorber layer ............... 115

3. Optical proprieties of CdS buffer layer and CIGS absorber layer: .............................. 118

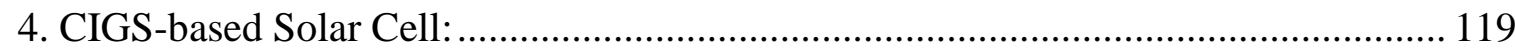




\section{Introduction.}

In this chapter, we elaborated different thin films constituted CIGS-based solar cells deposited by different techniques. In the objective to accomplish higher power conversion efficiency of the device $\mathrm{CdZnS} / \mathrm{CdS} / \mathrm{CIGS} / \mathrm{Mo}$, the window layer $(\mathrm{ZnO}, \mathrm{CdZnS})$ and the buffer layer CdS should transmit a large number of photons to reach the absorber layer and generate electrons holes pairs. The approach is to realize another material to change the toxic $\mathrm{ZnO}$ by using correctly the $\mathrm{CBD}$ technique. Moreover, our device $\mathrm{CdZnS} / \mathrm{CdS} / \mathrm{CIGS} / \mathrm{Mo}$ used a transparent, conductive CdZnS layer with optimizing the amount of doped materials, which makes it easy to minimize the interface alignment and to illuminate the p-n junction. Films CIGS, CdZnS, CdS were characterized by X-ray diffraction (XRD), Surface Electrons Microscopy (SEM), Atomic Force Microscopy (AFM) and UV-Vis Spectroscopy and CdZnS/CdS/CIGS/Mo solar cell efficiency was calculated and was characterized by measuring the current-density voltage $(\mathrm{J}-\mathrm{V})$ behavior under simulated AM 1.5 illumination (1000 $\left.\mathrm{W} / \mathrm{m}^{2}\right)$.

\section{Realization of CIGS solar cell}

CIGS thin films were elaborated by electrodeposition technique by using different precursors: $\mathrm{CuCl}_{2}, \mathrm{InCl}_{2}, \mathrm{GaCl}_{2}, \mathrm{H}_{2} \mathrm{SO}_{3}$.the precursor $\mathrm{LiCl}$ was used as a complexing agent and the $\mathrm{PH}$ was adjusted to 2.4 by adding some drops of concentrated $\mathrm{HCl}$. Three-electrode setup was done where Mo as back contact, Pt-plated counter electrode and $\mathrm{Ag} / \mathrm{AgCl}$ reference electrode and applied potential was fixed at $0.6 \mathrm{~V}$ [1]. The as-deposited CIGS thin films were annealed at $450{ }^{\circ} \mathrm{C}$ temperature for 40 minutes to enhanced the grain size and furthermore the crystallinity [2, 3].

The second step was to deposit the CdS buffer was deposited by a chemical bath deposition (CBD) method. The CIGS annealed was immersed in solution prepared containing $\mathrm{CdSO}_{4}(0.06 \mathrm{M})$, thiourea $\mathrm{CH}_{4} \mathrm{~N}_{2} \mathrm{~S}(0.75 \mathrm{M})$ and ammonia for controlling the $\mathrm{pH}$ solution at 11 . The bath temperature was maintained at $75^{\circ} \mathrm{C}$ temperature under magnetic sitting at $600 \mathrm{rpm}$ for one hour. CdS/CIGS/MO obtained had yellow color and it was washed by deionized water to eliminate the loosely bonded particles formed on the surface during deposition and then the sample was dried [4].

The last step was the n-type window layer deposition, involving the above process for $\mathrm{CdS}$ deposition by adding $\mathrm{ZnSO}_{4}(0.1 \mathrm{M})$ as a source of $\mathrm{Zn}^{+2}$, CdS-doped $\mathrm{Zn}$ which is named CdZnS film. In the end, the last finger-patterned film of $\mathrm{Au}(80 \mathrm{~nm})$ for the electron collection was deposited by 
using the evaporation method. The devise had SLG/Mo/CIGS/CdS/CdZnS/Au structure. the X-ray diffraction (XRD) analysis with $\mathrm{Cu}-\mathrm{K} \alpha$ radiation $(\lambda=1.54 \AA$ ) was carried to characterize the films CIGS, CdS, CdZnS prepared. Composition and microstructure of the films were examined using EDS and scanning electron microscopy (SEM) were used to examine the microstructure and composition. The Atomic force microscopy (AFM) was carried to analysis the surface morphology and roughness, $\mathrm{UV}-\mathrm{Vis}$ spectroscopy was used for the measurement optical properties. The performance of SLG/Mo/CIGS/CdS/CdZnS/Au solar cells was evaluated using a solar simulator under AM 1.5 intensity to find current and voltage (J-V) curves characteristic.

\section{Structural and morphology of CdS buffer layer and CIGS absorber layer.}

XRD analysis of CIGS as-deposited films showing less crystallinity. The annealing treatment of the CIGS films at $450{ }^{\circ} \mathrm{C}$ for 40 min improved the crystallinity of the film as can be seen from fig 5.1. Appearance of major peaks matches well with the tetragonal crystal system JCPDS No. 0750104 pattern, corresponding to $\mathrm{CuGaSe}_{2}$ phase (112), (220/204) and (312), the improvement in crystallinity is an indication after heat treatment [5].

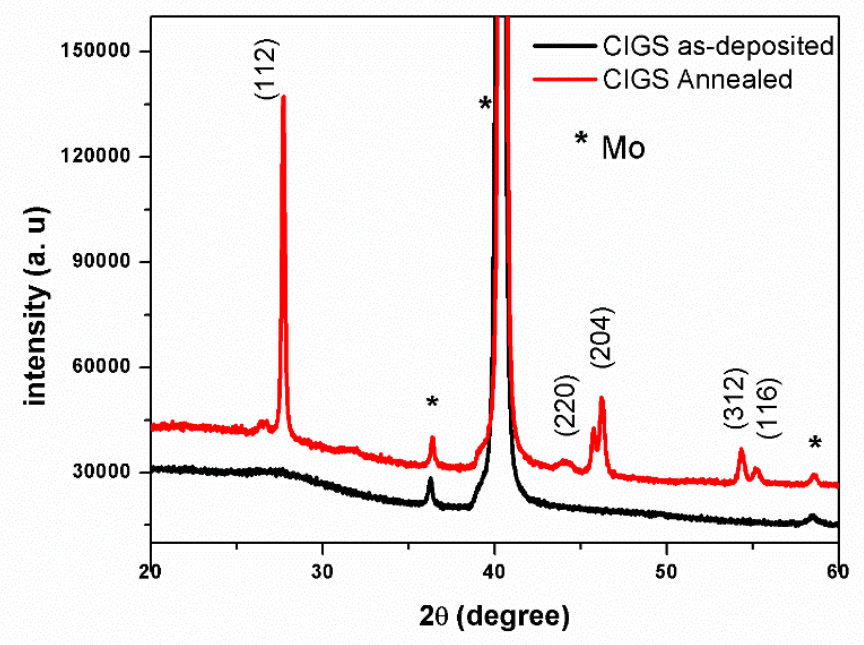

Figure 5.1: XRD patterns of electrodeposited CIGS.

Thin CdS films annealed at $400{ }^{\circ} \mathrm{C}$ were analyzed for structure with X-ray diffraction. Diffraction peaks correspond to (002), (110) and (103) plane with a higher intensity is an indication 
of polycrystallinity of the CdS films [6]. On the other hand, diffraction peaks of thin layers CdS doped with a $5 \%$ of $\mathrm{Zn}$ are identified on the same $2 \theta$ values as can be seen in Figure 5.2 with a decrease in the intensity of the diffraction peaks. This decrease in intensity is an indication of the decreases in the crystallinity of ternary $\mathrm{CdZnS}$ layer. This result is attributed to the decrease of the lattice parameter of $\mathrm{CdZnS}$ that come with substituting $\mathrm{Zn}^{2+}\left(88 \mathrm{pm}\right.$ ), for $\mathrm{Cd}^{2+}$ ions of (109 pm) (which has a smaller atomic size) which lead to a wide-angle and influence CdS layer crystallinity [7].

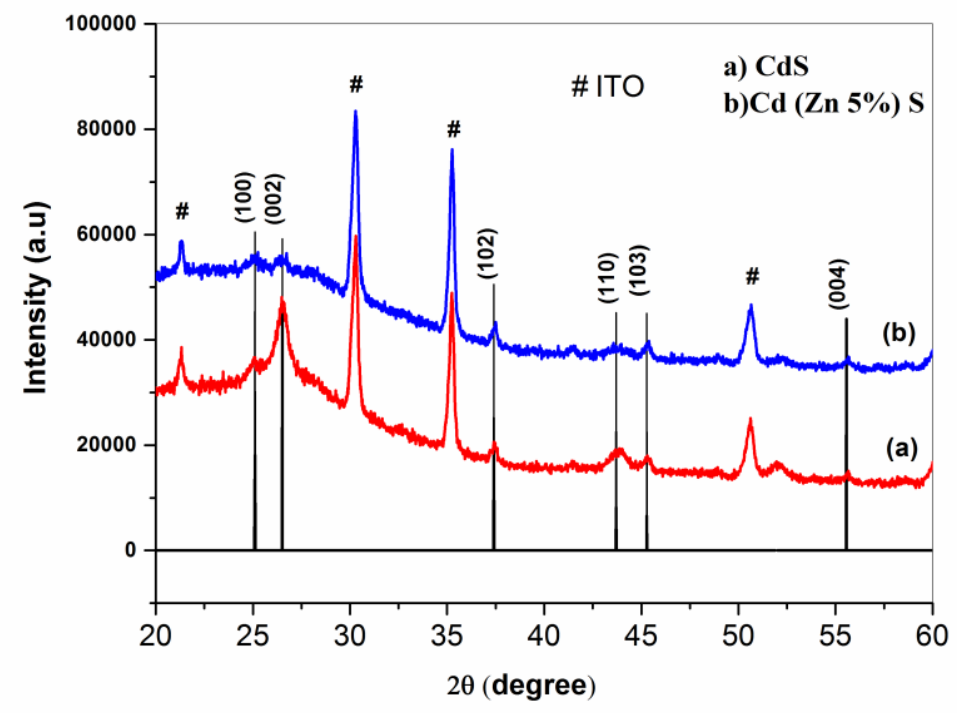

Figure 5.2 XRD patterns of deposited (a) CdS and (b) CdZnS.

Figure 5.3 shows the surface morphology of as deposited and annealed CIGS samples. The SEM images have a homogenous and smooth surface with a smaller grain size for the as-deposited films. However, the granular crystallites ware observed in CIGS thin films, their size increased with annealing temperature. This increase in grain size produces a large number of grain boundaries that prevent charge carrier recombination, which causes a significant improvement in the conversion efficiency of solar cells [8]. 

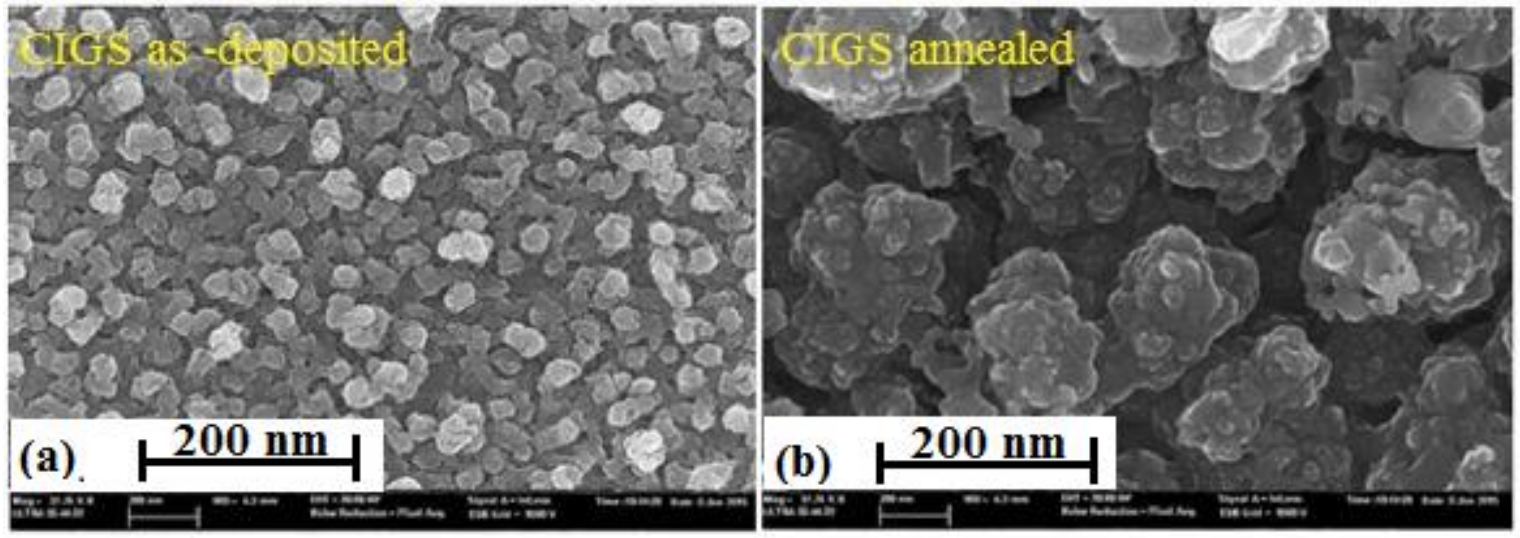

Figure 5.3. SEM images of the thin film CIGS elaborated (a) as-deposited and (b) after annealing.

Figure 5.4 shows the SEM analysis of CdS and CdZnS thin films. Uniform and more smother like fiber wire structure was obtained with increases in $\mathrm{Zn}$ content. It is observed that the decrease in the grain size with $\mathrm{Zn}$ content may be useful for solar cells application using as a window layer [9, $10]$.
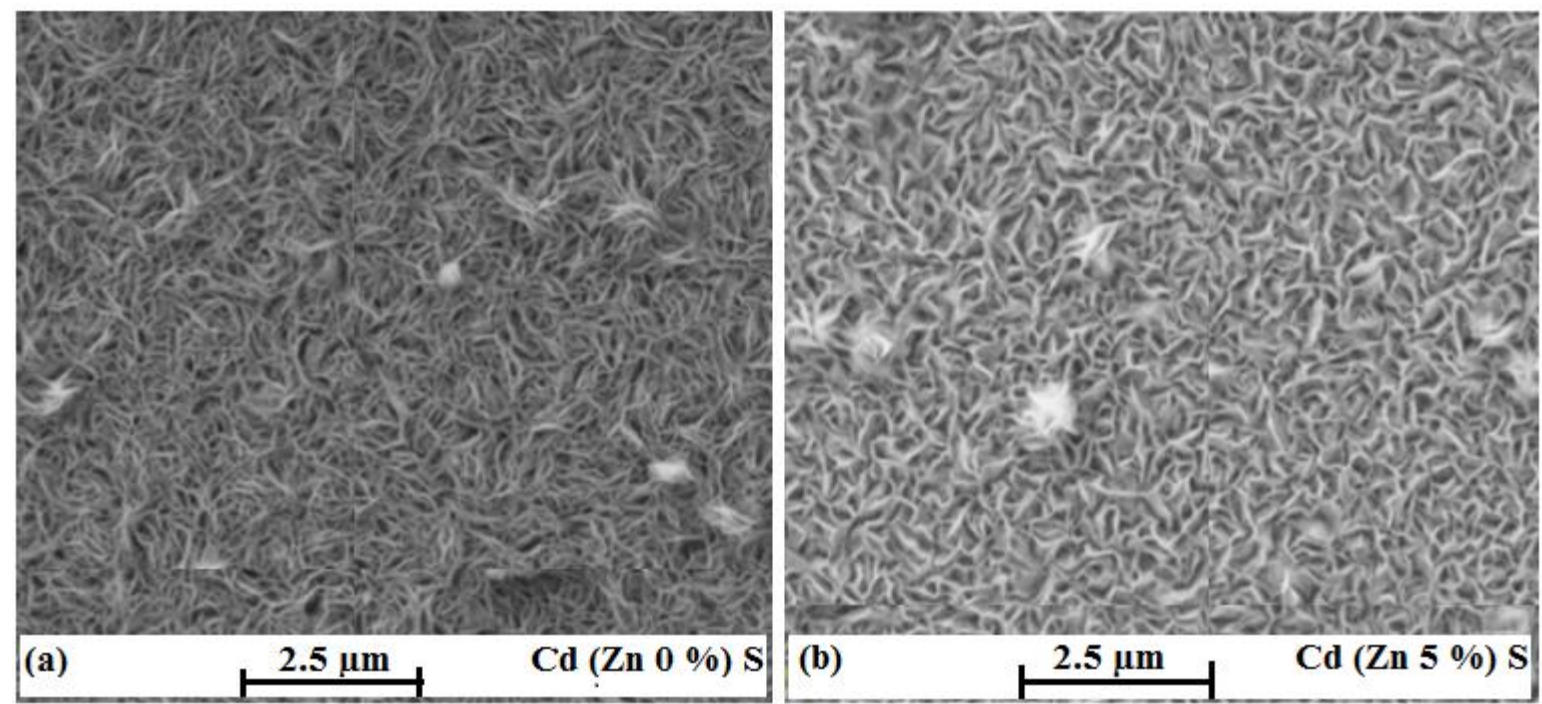

Figure 5.4. SEM images of the films synthesized (a) $\mathrm{Cd}(\mathrm{Zn} 0 \%) \mathrm{S}$ and (b) $\mathrm{Cd}(\mathrm{Zn} 5 \%) \mathrm{S}$

Figure 5.5 presents the topography of CIGS, CdS, and CdZnS thin films analyzed by atomic force microscope (AFM). It can be seen that the films changed the surface to thin fine particles. According to AFM analysis which is important for thin films due to its contribution to electrical and mechanical properties, the surface topography was found to be influenced by the incorporation of $\mathrm{Zn}$ content. The fine roughness and small grain in the films were observed and their size gradually becomes smaller with the $\mathrm{Zn}$ content. This is an indication that due to the incorporation of $\mathrm{Zn}$ the 
roughness of the films decreases. This increases the transmittance of the incident lights and prevent the recombination to generate more hole-pair in the absorber layer.

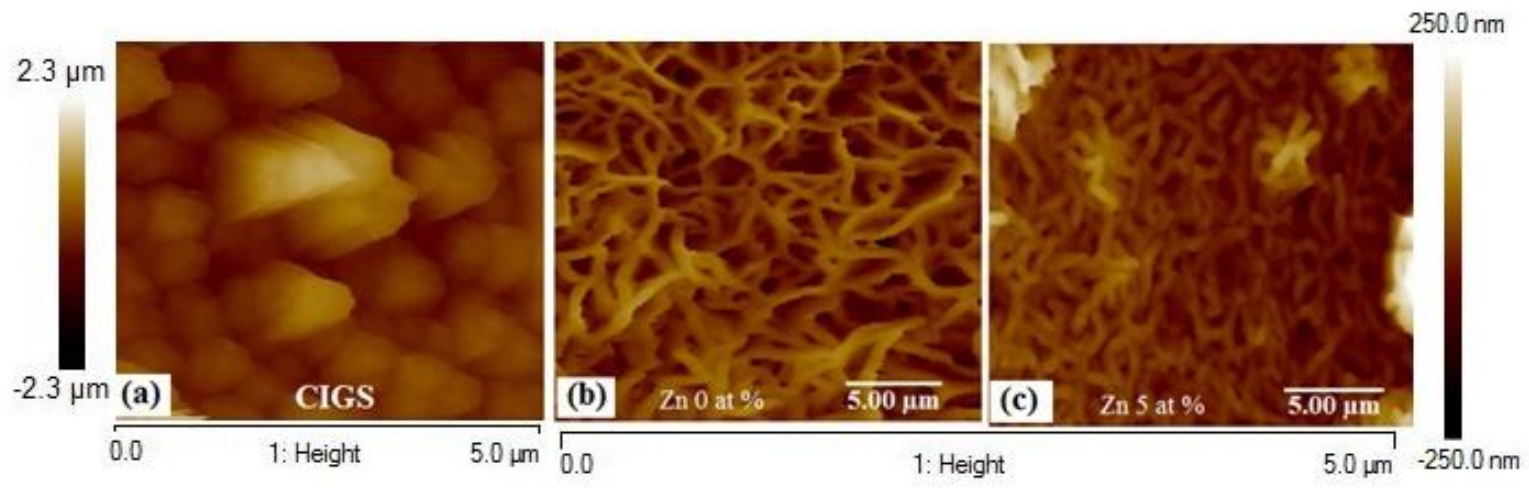

Figure 5.5. AFM (2D) images (2D) of surface morphologies (a) CIGS (b) CdS and (c)CdZnS.

\section{Optical proprieties of CdS buffer layer and CIGS absorber layer:}

The optical properties of CIGS thin films such as absorbance and bandgap energy varied with wavelength $(\lambda)$ in the series of 400 to $900 \mathrm{~nm}$, the material has good absorption in the visible region. Thin CIGS layer is considered a direct bandgap semiconductor material. The bandgap energy was determined from the absorbance data by plotting $(\mathrm{Ah} v)^{2}$ versus hv to the energy axis at $(\mathrm{Ah} v)^{2}=0$, where $\mathrm{A}$ is the absorbance and hv photon energy [11]. The obtained bandgap for CIGS thin films is $1.6 \mathrm{eV}$ which is favorable for the absorber layer and it is shown in figure 5.6.

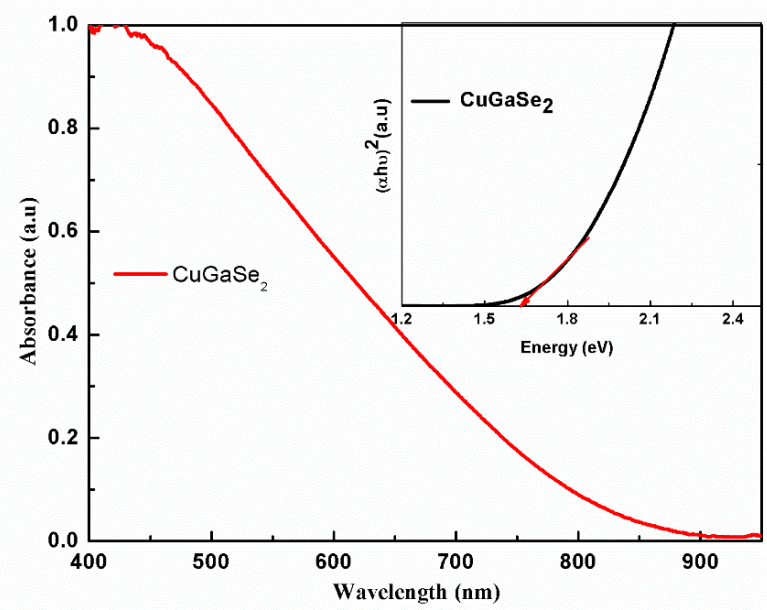

Figure 5.6. Optical Absorption and band gap of CIGS annealed. 
Figure 5.7 (a) shows the absorbance of $\mathrm{CdS}$ and $\mathrm{CdZnS}$ thin films in the range of 300 to 650 $\mathrm{nm}$ wavelength. The optical band gap was calculated as discussed previously for $\mathrm{CdS} 2.48 \mathrm{eV}$ and $\mathrm{CdZnS} 3.05 \mathrm{eV}$ (Figure 5.7 (b)). The variation in the bandgap energy from 2.48 to $3.05 \mathrm{eV}$ shows a great interest due to 5 atomic\% $\mathrm{Zn}$ incorporation in $\mathrm{CdS}$, which is considered a promising window layer for CIGS-based solar cells to decrease the absorption in the window layer and exhibit high transmittance over a wide range of wavelength [12].
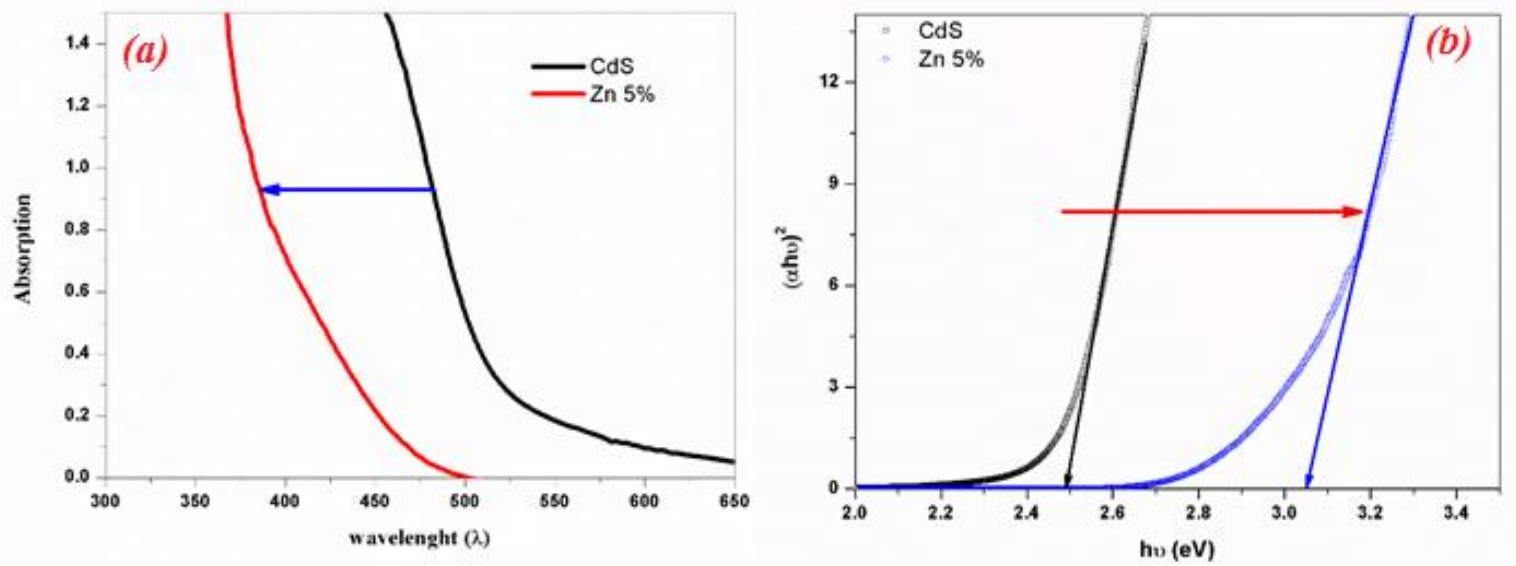

Figure 5.7. Optical Absorption and band gap of $\mathrm{CdS}$ and $\mathrm{CdZnS}$ annealed

\section{CIGS-based Solar Cell:}

The devise performance of CIGS-based solar cells configuration shown in figure 5.8 (a), was characterized by measuring the current-density voltage $(\mathrm{J}-\mathrm{V})$ behavior under simulated AM 1.5 illumination $\left(1000 \mathrm{~W} / \mathrm{m}^{2}\right)$. The best device performance is recorded $2.2 \%$ in figure $8(\mathrm{~b})$, Open-circuit voltage, short circuit current and fill factor $\left(\mathrm{Voc}=345 \mathrm{mV}, \mathrm{Jsc}=16.8 \mathrm{~mA} / \mathrm{cm}^{2}\right.$ and $\left.\mathrm{FF}=38.18 \%\right)$ was obtained with a $5 \% \mathrm{Zn}$ content respectively. The achieved efficiency is relatively lower than those of the literature. We can observe that the device has some natural defects such as recombination loss at grain boundaries and series resistance which cannot boost the efficiency of the device. The comparison of our CIGS device with different works fabricated by various techniques is illustrated in Table 5.1. 

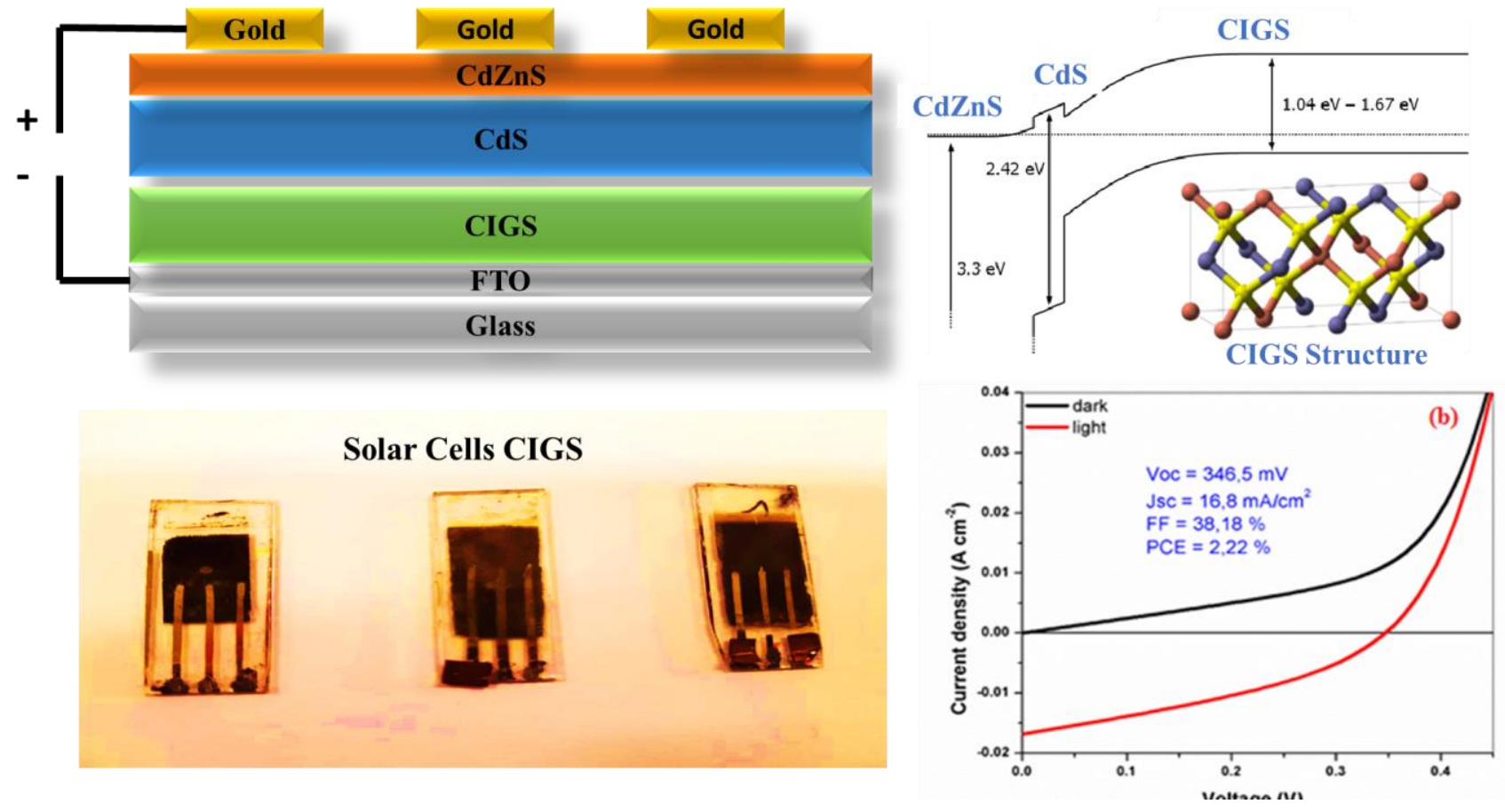

Figure 8 (a). A typical device SLG/Mo/CIGS/CdS/CdZnS/Au structure configuration and (b) J-V characteristic curve dark and under illumination.

Table 5.1. Photovoltaic parameters for different CIGS solar cells, including fabrication methods.

\begin{tabular}{|c|c|c|c|c|c|c|}
\hline \multirow[t]{2}{*}{ Cell structure } & \multirow{2}{*}{$\begin{array}{l}\text { Fabrication } \\
\text { technique }\end{array}$} & \multicolumn{4}{|c|}{ PV parameters } & \multirow[t]{2}{*}{ References } \\
\hline & & $\mathrm{Jsc}\left[\mathrm{mA} / \mathrm{cm}^{2}\right]$ & Voc $[\mathrm{mV}]$ & $\mathbf{F F}[\%]$ & $\eta[\%]$ & \\
\hline $\mathrm{ZnO} / \mathrm{CdS} / \mathrm{CuGaSe}_{2} / \mathrm{Mo}$ & Electrodeposition & 14.9 & 546.0 & 50.8 & 4.10 & [26] \\
\hline $\mathrm{ZnO} / \mathrm{CdS} / \mathrm{CIGS} / \mathrm{Mo}$ & Co-evaporation & 35.2 & 538.2 & 69.6 & 13.20 & [27] \\
\hline ZnO/CdS/CIS/ITO & coating process & 25.8 & 280.0 & 39.0 & 2.82 & [28] \\
\hline $\begin{array}{l}\mathrm{ZnO}, \mathrm{CdZnS} / \mathrm{CdS} / \mathrm{CIGS} / \mathrm{F} \\
\text { TO }\end{array}$ & $\begin{array}{c}\text { Electrodeposition } \\
\text { and CBD }\end{array}$ & 16.8 & 346.5 & 38.18 & 2.22 & Our work \\
\hline
\end{tabular}

\section{Conclusion:}

In this study, the CIGS-based solar cell was proposed, which consisted of a sequential process electrodeposition for CIGS absorber layer and chemical bath deposition for buffer and window layer. The annealing treatment plays an important role in the device performance which increased the grain size and crystallinity of the absorber layer to collect more light. The CdS buffer layer and CdS doped with 5 atomic $\% \mathrm{Zn}$ were examined where the following results were observed; i) decrease in the 
surface roughness, ii) substitution of $\mathrm{Zn}$ for $\mathrm{Cd}$ and iii) an increase in the optical bandgap. The increasing bandgap is an indication to cover the high energy wavelength in the visible region to transmit the high energy photons. The CIGS-based device was fabricated with a $5 \% \mathrm{Zn}$ content had a conversion efficiency of $2.2 \%$, a Voc of $345 \mathrm{mV}$, a Jsc of $16.8 \mathrm{~mA} / \mathrm{cm}^{2}$ and fill factor of 38.18 $\%$. The achieved efficiency is relatively lower than those of the literature, the proposed study could be an alternative for replacing sputtering-based deposition by chemical bath deposition to reduce the overall production cost of the device.

\section{References:}

[1] S.H. Han, A. M. Hermann, F. S. Hasoon, H. A. Al-Thani and D. H. Levi, Appl. Phys. Lett. 85, 576-578 (2004).

[2] A. Bouich, B. Hartiti, S. Ullah, H. Ullah, M. E. Touhami, D. M. F. Santos, \& B. Mari. Applied Physics A, 125 (8) 579 (2019).

[2] S. Marc, T. Matthieu, S. Susanne and J.D. Phillip. Phys. Chem. Chem. Phys. 13, 4292-4302 (2011).

[3] C. C. Chen, X. Qi, M. G. Tsai, Y. F. Wu, I. G. Chen, C. Y. Lin and K. P. Chang. Surface and Coatings Technology, 231, 209-213 (2013).

[4] S. H. Mousavi, T. S. Müller and P. W. Oliveira. Journal of colloid and interface science, 382(1) 48-52 (2012).

[5] S. Ahn, K. H. Kim, J. H. Yun and K. H. Yoon. Journal of applied physics, 105 (11) 113533 (2009).

[6] B. Sang, K. Kushiya, D. Okumura and O. Yamase. Solar energy materials and solar cells, 67(14) 237-245 (2001).

[7] S. Jung, S. Ahn, J. H. Yun, J. Gwak, D. Kim and K. Yoon, Current Applied Physics, 10(4) 990996 (2010).

[8] V. S. Saji, I. H. Choi and C. W. Lee. Solar Energy, 85 (11) 2666-2678 (2011).

[9] Z. Li, L. Fang-fang, L. Feng-yan, H. Qing, L. Bao-zhang, and L. Chang-jian. Solar Energy Materials \& Solar Cells. 99, 356-36 (2012)

[10] C.D.R. Ludwig, T. Gruhn, F. Claudia, S. Tanja, W. Johannes, K. Peter. Phys. Rev. Lett. 105, 025702/1-4 (2010).

[11] D. Hariskos, M. Powalla, N. Chevaldonnet, D. Lincot, A. Schindler and B Dimmler. Thin Solid Films, 387 (1-2) 179-181 (2001).

[12] H. W. Schock and R. Noufi, Prog. Photovolt. Res. Appl. 8, 151-160 (2000).

[13] I. Repins, M. A. Contreras, B. Egaas, C. DeHart, J. Scharf, C. L. Perkins, B. To and R. Noufi, Prog. Photovolt. Res. Appl. 16, 235-239 (2008).

[14] D. Lincot, J. F Guillemoles, S. Taunier, D. Guimard, J. Sicx-Kurdi, A. Chaumont and N. Bodereau. Solar Energy, 77 (6) 725-737 (2004).

[15] R. Friedfeld, R. P. Raffaelle and J. G. Mantovani. Solar Energy Materials and Solar Cells, 58 (4) 375-385 (1999).

[16] L. Zhang, F.D. Jiang and J.Y. Feng. Solar energy materials and solar cells, 80 (4) 483-490 (2003). 
[17] M. A. Contreras, M. J. Romero, B. To, F. Hasoon, R. Noufi, S. Ward and K. Ramanathan. Thin Solid Films, 403, 204-211 (2002).

[18] T. Wada, N. Kohara, S. Nishiwaki and T. Negami. Thin Solid Films, 387 (1-2) 118-122 (2001).

[19] M. Stoev and A. Katerski. Journal of Materials Chemistry, 6 (3) 377-380 (1996).

[20] D. Patidar, N. S. Saxena and T. P. Sharma. Journal of Modern Optics, 55 (1) 79-88 (2008).

[21] M. Gloeckler, J. R. Sites, and W. K. Metzger, J. Appl. Phys., 98 (2005).

[22] M. B. Ård, K. Granath and L. Stolt. Thin Solid Films, 361, 9-16 (2000).

[23] V. B. Sanap and B. H. Pawar. Journal of Optoelectronics and Biomedical Materials, 3 (2) 39-43 (2011).

[24] M. E. Calixto, P. J. Sebastian, R. N. Bhattacharya and R. Noufi. Solar energy materials and solar cells, 59 (1-2) 75-84 (1999).

[25] G. Jia, N. Wang, L. Gong and X. Fei. Chalcogenide Letters, 7(5) 377-383 (2010).

[26] S. Marc, T. Matthieu, S. Susanne, J.D. Phillip. Phys. Chem. Chem. Phys. 13, 4292-4302 (2011).

[27] Z. Li, L. Fang-fang, L. Feng-yan, H. Qing, L. Bao-zhang, L. Chang-jian. Solar Energy Materials \& Solar Cells. 99, 356-361(2012).

[28] G. Qijie, J.K. Suk, K. Mahaprasad, N.S. William, W.B. Robert, A.S. Eric, A. Rakesh, W.H. Hugh. Nano Lett. 8, 2982-2987 (2008).. 


\section{Chapter VI}

\section{Synthesis and characterization of Methylammonium Lead Iodide $\left(\mathrm{MAPbI}_{3}\right)$ perovskite}

\section{Contents}

1. The Study of $\mathrm{MAPbI}_{3}$ Perovskite Thin Films.

124

1.1. Film Preparation of $\mathrm{MAPbI}_{3}$ with different amount of antisolvent perovskite films. 124

1.2. Structural and morphological analysis of $\mathrm{MAPbI}_{3}$ Perovskite Thin Films 126

1.3. Optical properties of $\mathrm{MAPbI}_{3}$ perovskite films

2. Degradation study of $\mathrm{MAPbI}_{3}$ 132

3. Methylammonium lead triiodide $\mathrm{MAPbI}_{3}$ doping by Tetrabutylammonium (TBA) Perovskites Thin films. 135

3.1. Film Preparation of $\mathrm{MAPbI}_{3}$ doped Tetrabutylammonium perovskite films 136

3.2. Structural and morphological analysis of $\mathrm{MAPbI}_{3}$ doped Perovskite Thin Films 136

3.3. Optical properties of $\mathrm{MAPbI}_{3}$ doped TBA perovskite films. .127

4. Degradation study of $\mathrm{MAPbI}_{3}$ doped TBA: 143

5. Methylammonium lead triiodide $\mathrm{MAPbI}_{3}$ doping by $\mathrm{Rb} / \mathrm{Li} / \mathrm{Cs}$ Perovskites Thin films. 146 


\section{Introduction}

Crystallization is accomplished by slowing down the solubility in a saturated solution by Evaporation, Cooling, Adding Anti-Solvent or mixing of the above procedures. In our work, the film surface was treated by adding diethyl ether antisolvent with different rates that directly influences the level of supersaturation and thermal annealing. during the treatment complex exchanges are appearing at the same time under the influence of quite a lot of physicochemical properties. A whole understanding of this topic is critically important for improving solar cell performance.

In this work, we studied the effect of different amount of diethyl ether on tailoring the properties of $\mathrm{MAPbI}_{3}$ films. The obtained perovskite thin films were studied by scanning electron microscopy (SEM), X-ray diffraction (XRD), transmission electron microscope (TEM), Atomic Force Microscopy (AFM) and UV- Visible spectrometer.

\section{The Study of $\mathrm{MAPbI}_{3}$ Perovskite Thin Films \\ 1.1. Film Preparation of $\mathrm{MAPbI}_{3}$ with different amount of antisolvent perovskite films.}

The perovskite absorber Lead halide hybrid $\mathrm{MAPbI}_{3}$ were elaborated in inert environment inside the Glovebox to avoid all the degradation conditions and to keep all samples safe. As shown in figure 6.1 . 


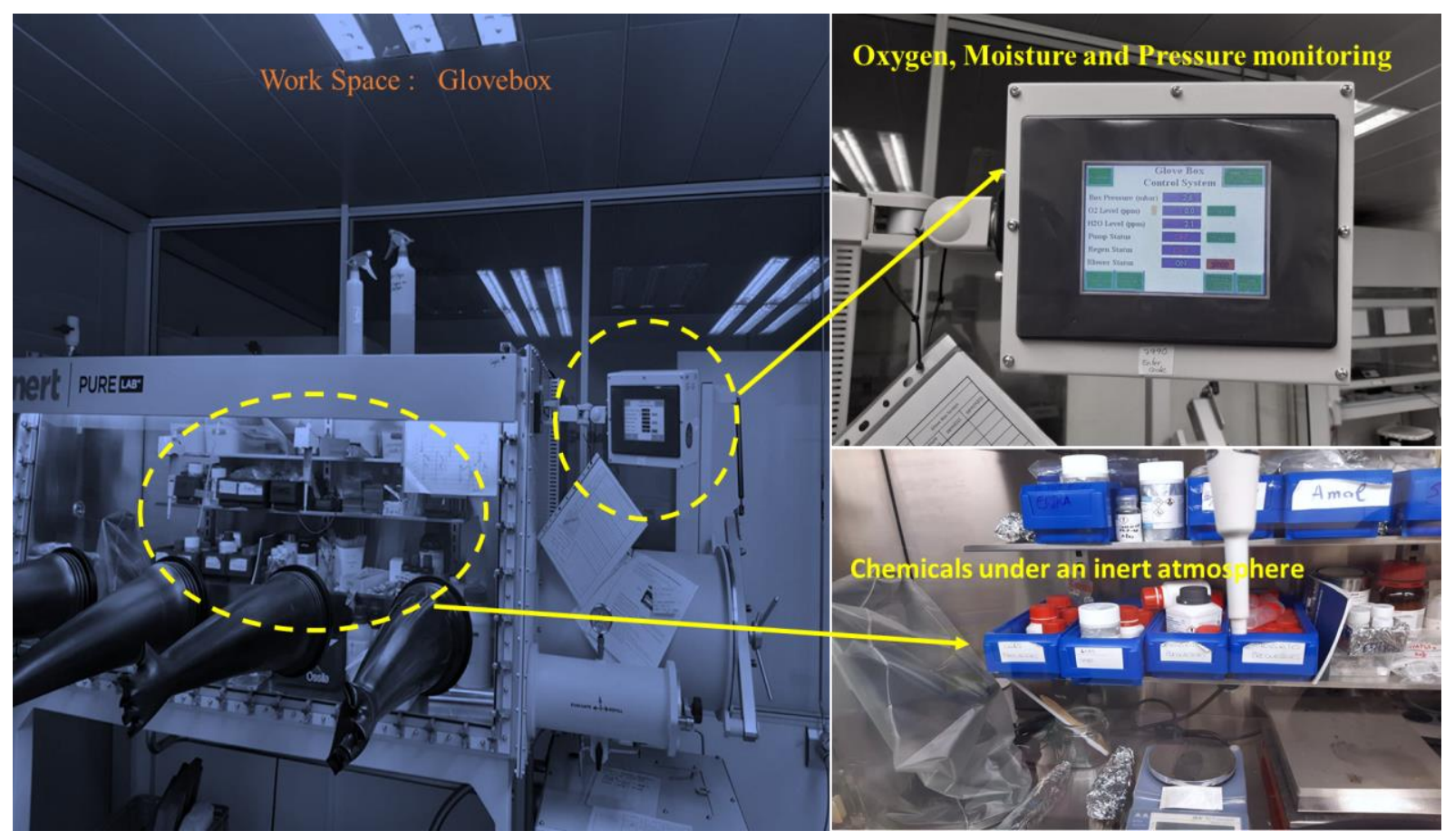

Figure 6.1 glovebox machine for elaboration of perovskite thin films

\section{Cleaning procedure:}

Sample cleaning

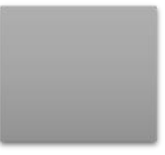

FTO Glass

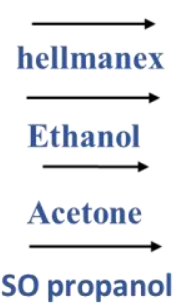

iso rovenana
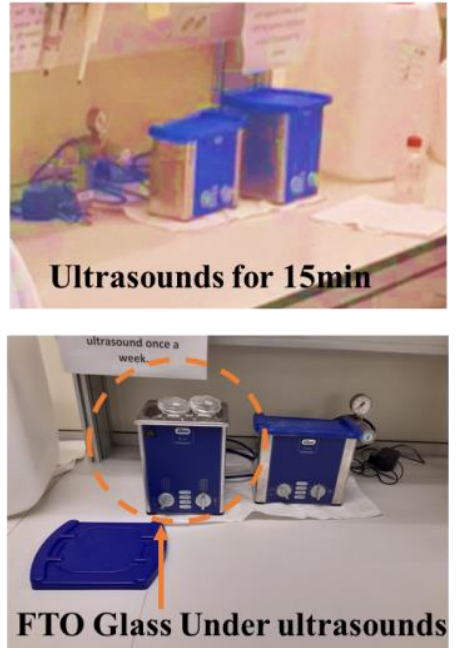

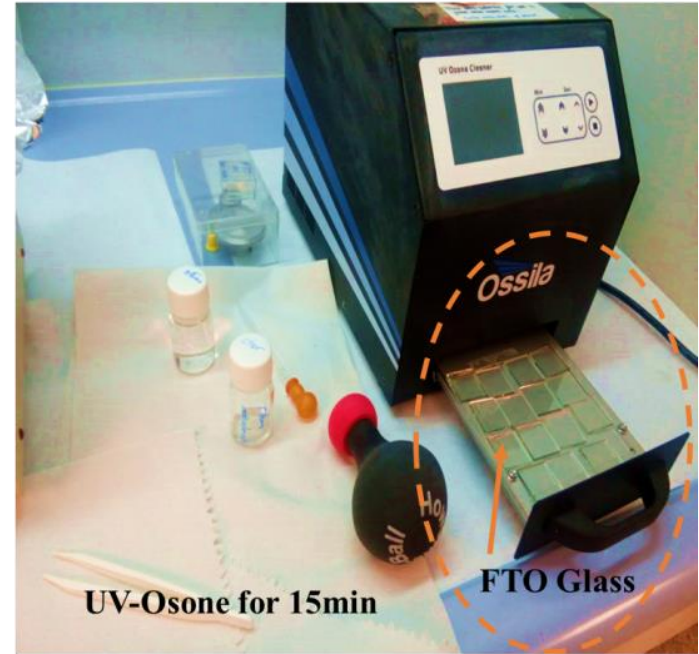

UV-Osone for 15min

Figure 6.2 Different steps for cleaning the FTO substrate

The perovskite absorber Lead halide hybrid $\mathrm{MAPbI}_{3}$ were elaborated using different precursors commercially available. In particular, the compounds lead iodide $\left(\mathrm{PbI}_{2}\right)$, Methylammonium iodide (MAI) were used and Dimethyl Sulfoxide (DMSO) and N, N-dimethylformamide (DMF) like solvents. First, the prepared solution of $\mathrm{MAPbI}_{3}$ was dropped into Fluorine doped Tin Oxide (FTO) 
Glass that it was cleaned like it shown in figure 6.2, The substrates were carefully cleaned with detergent, acetone and isopropanol (IPA) each for 15 min holding time respectively, in an ultrasonic bath. The cleaned FTO substrates were dried in air and finally kept in UV ozone cleaner for $15 \mathrm{~min}$. The substrate was spin at $3000 \mathrm{rpm}$ for 30 seconds after it comes to the diethyl ether treatment, the diethyl ether was dropped and directly spun at $5000 \mathrm{rpm}$ for 30 seconds. Different amounts of the Antisolvent diethyl ether was dropped on the substrate during spin coating $(1 \mathrm{ml}, 1.5 \mathrm{ml}, 2.5 \mathrm{ml}$ and $3 \mathrm{ml}$ ) of diethyl ether. Then The substrate was annealed at $90^{\circ}$ for 30 minutes as illustrate in figure 6.3 .

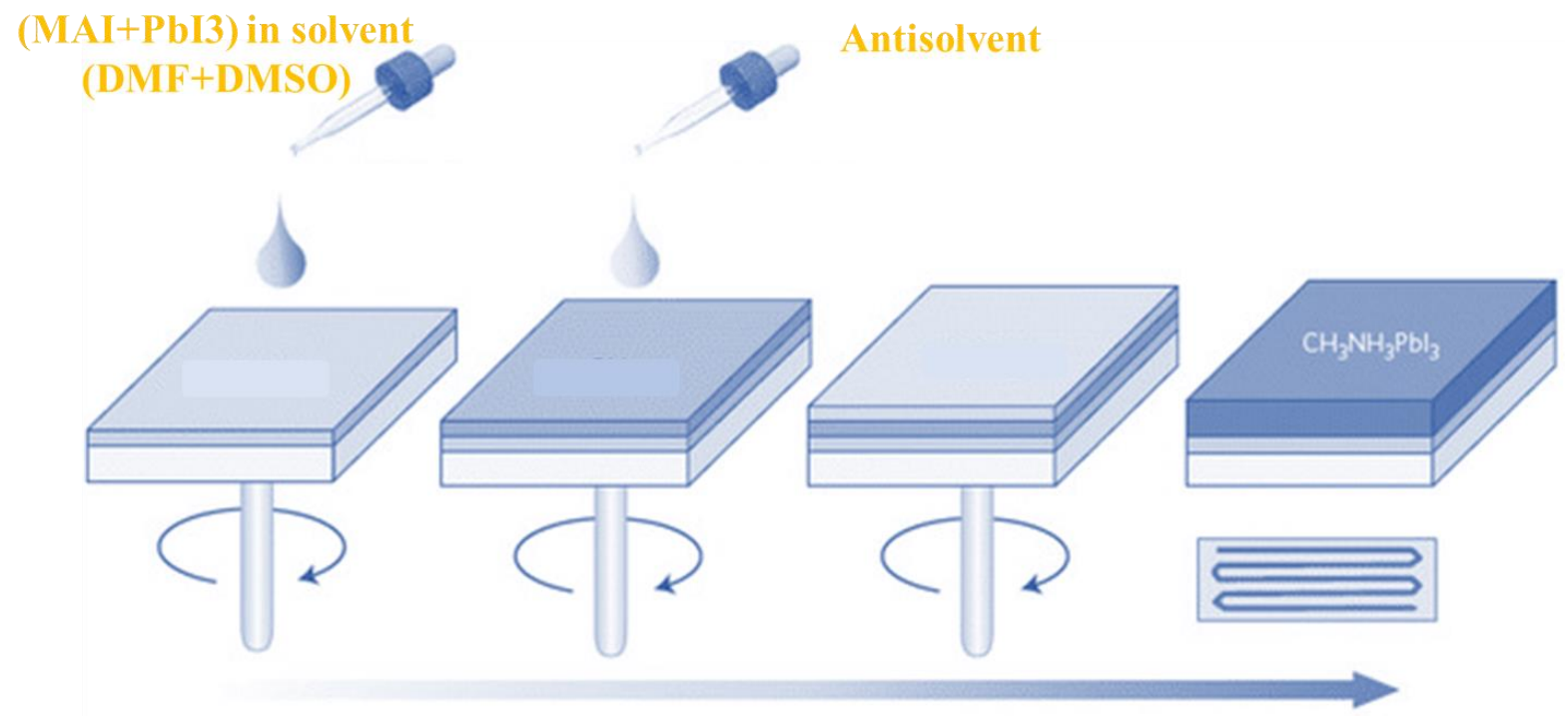

Figure 6.3 schema illustrate deposition procedure of perovskite thin film

\subsection{Structural and morphological analysis of MAPbI3 Perovskite Thin Films}

The impact of the antisolvent treatment on microstructure of the thin films was examined by XRD in Figure. 6.4 (a), it is observed from the XRD analysis that several diffractions peaks are located at 14.0, 24.0, 28.0, 32.0, 37.5 and 52.0, which corresponds to the planes of (110), (202), (220), (222), (400) and (303) respectively. The same diffraction peaks are correlated the previous $\mathrm{MAPbI}_{3}$ structure study $[1,10]$. In addition, it was found that the intensity of the (110) peak is increased when the added volume of the diethyl ether varies from 1 to $2.5 \mathrm{ml}$. However, when the diethyl ether quantity is greater than the optimal value of $2.5 \mathrm{~mL}$, the (110) peaks intensity decreases due to the high solubility of methylammonium iodide (MAI) which causes its removal from the perovskite structure. The XRD pattern revealed the improved crystallite orientation along the (110) plane. Such preferential orientation can be originated from the pre crystallization step of the $\mathrm{MAPbI}_{3}$ crystallites 
in the presence of the solvent treatment. All perovskite films crystallize in a tetragonal lattice corresponding to the space group $\mathrm{I} 4 / \mathrm{mcm}$. The lattice parameters were found to be $\mathrm{a}=\mathrm{b}=8.919 \AA$, $\mathrm{c}=11.920 \AA$.
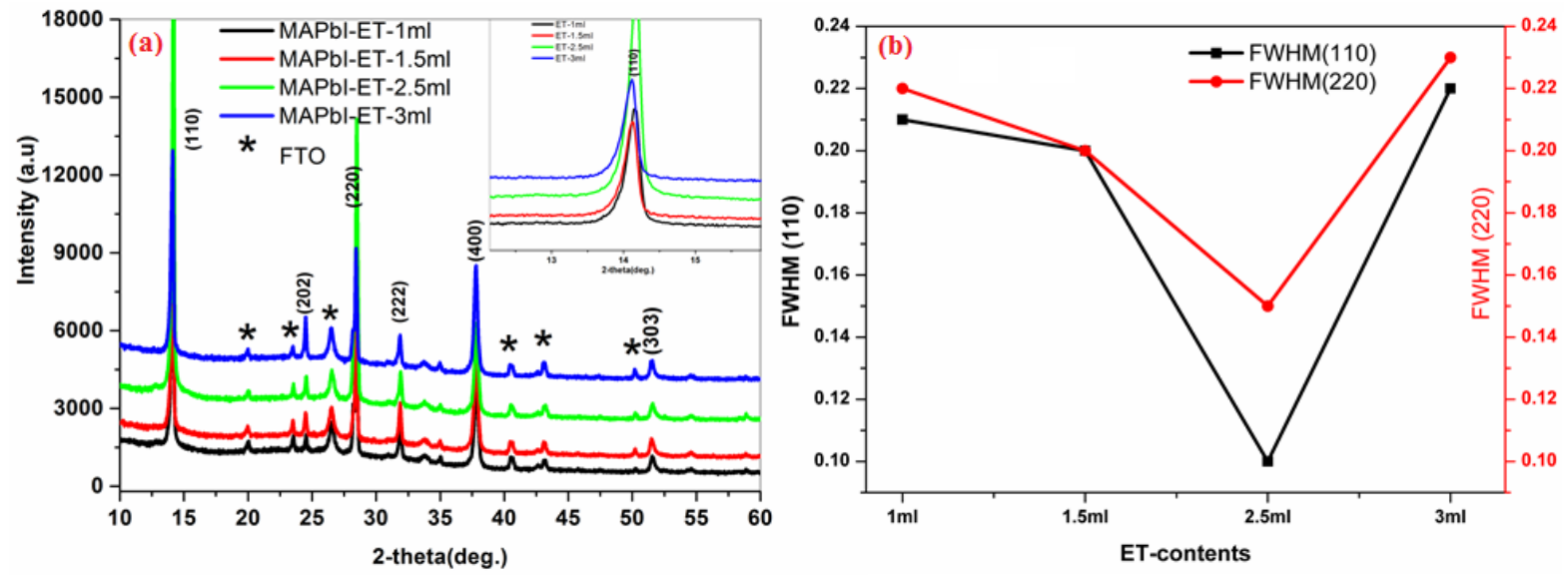

Figure 6.4. (a) the obtained XRD patterns with different amounts of antisolvent. (b) The Full width at half maximum (FWHM) for the $(110,220)$ peaks.

Figure 6.4 (b) for the peaks $(110,220)$ the Full width at half maximum (FWHM) values decrease for the samples treated with $3 \mathrm{ml}$ amount of diethyl ether in different peaks characteristics to $\mathrm{MAPbI}_{3}$, Effective lattice strain is been calculated to have idea about the deficiencies and deformations of the grains in the thin film. Equation (6.1) was used to determine the effective lattice strain $(\varepsilon)$. The grain size (D) of the films has been found in range $310 \mathrm{~nm}$ to $400 \mathrm{~nm}$ Table 6.1 .

$$
\beta \cos (\theta)=\frac{\mathrm{k} \lambda}{\mathrm{D}}+4 \varepsilon \sin (\theta)
$$

Where $\theta$ is the Bragg angle, $\mathrm{K}$ is constant (0.94) is the full-width half maximum (FWHM), $\lambda$ is the wavelength of X-ray. The dislocation density of the crystal was evaluated using the equation (6.2).

$$
\gamma=1 / \mathrm{D} 2
$$

As summarized in Table 6.1, grain size, dislocation density and lattice strain values. It was found that the grain size significant increase upon the addition of diethyl ether $1 \mathrm{ml}, 1.5 \mathrm{ml}, 2 \mathrm{ml}$ and $2.5 \mathrm{ml}$, $310 \mathrm{~nm}, 333 \mathrm{~nm}$ and $400 \mathrm{~nm}$ respectively. whereas obviously the grain size became decrease $300 \mathrm{~nm}$ upon the addition of diethyl ether $3 \mathrm{ml}$. This indicate that the addition of more than the optimum level $(2.5 \mathrm{ml})$ affect the grain sizes and others related parameter which is good agreement with the XRD analysis. The XRD study revealed the good impact of ET antisolvent treatment on the grain size

Table 6.1: The grain size, dislocation density and lattice strain of $\mathrm{XRD}$ of $\mathrm{MAPbI}_{3}$ thin films. 


\begin{tabular}{|l|c|c|c|c|}
\hline Sample.ID & $\begin{array}{c}\text { Grain Size } \\
(\mathbf{n m})\end{array}$ & $\begin{array}{c}\text { Roughness } \\
(\mathbf{n m})\end{array}$ & $\begin{array}{c}\text { Dislocation density } \\
\left(\mathbf{n m}^{-\mathbf{1}}\right)\end{array}$ & $\begin{array}{c}\text { Lattice strain } \\
(\boldsymbol{\varepsilon})\end{array}$ \\
\hline ET-1ml & 310 & 39 & $1.04 \times 10^{-05}$ & 0.38 \\
\hline ET-1.5ml & 333 & 41 & $0.90 \times 10^{-05}$ & 0.39 \\
\hline ET-2.5ml & 400 & 46.73 & $0.62 \times 10^{-05}$ & 0.39 \\
\hline ET-3ml & 300 & 36.99 & $1.11 \times 10^{-05}$ & 0.37 \\
\hline
\end{tabular}
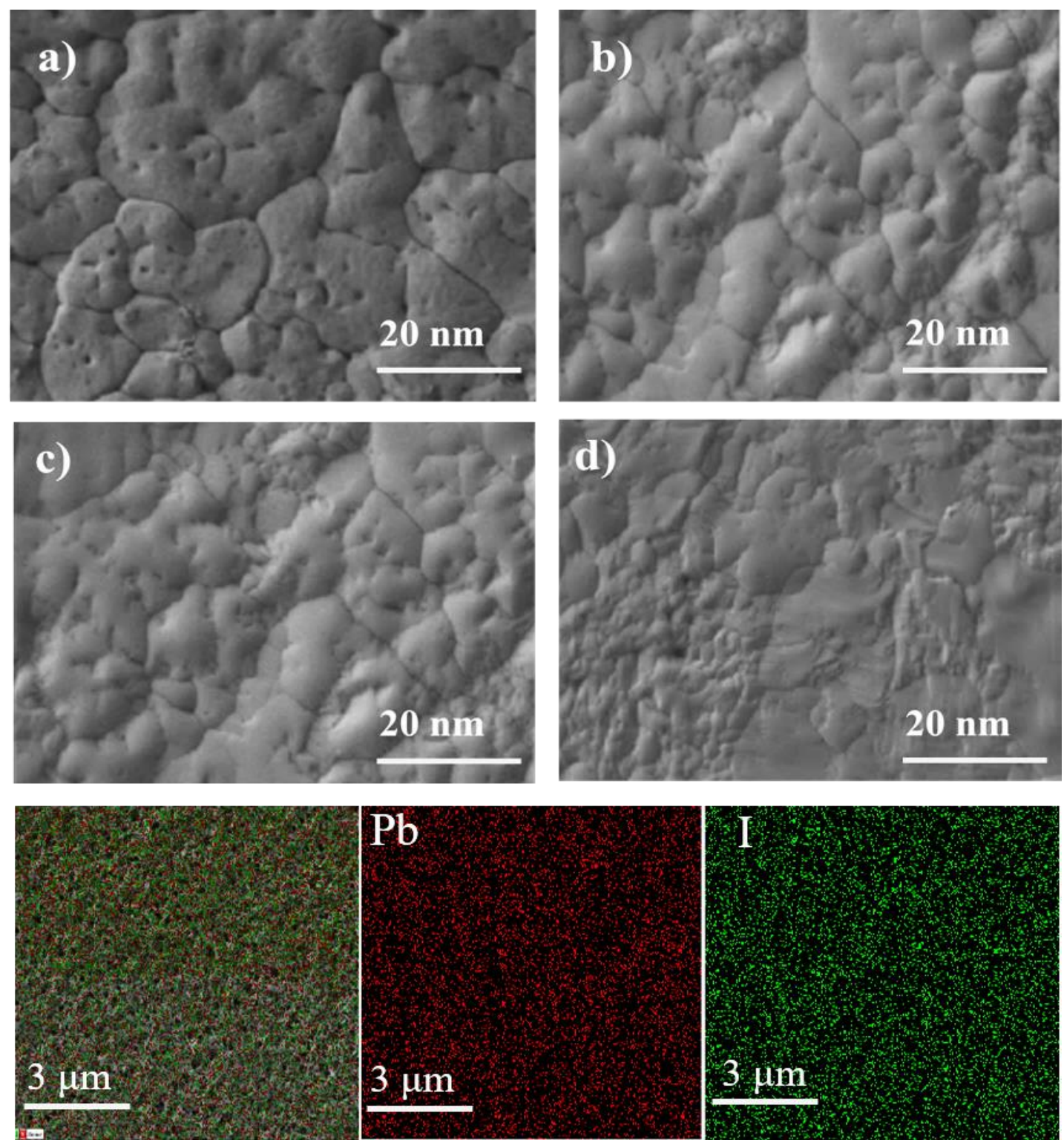

Figure 6.5. SEM images of $\mathrm{MaPbI}_{3}$ with different amounts of Antisolvent diethyl ether (a 1ml, b $1.5 \mathrm{ml}, \mathrm{c} 2.5 \mathrm{ml}, \mathrm{d} 3 \mathrm{ml}$ ) and (e) Mapping of halide perovskite.

Figure 6.5 displays the SEM images of multiple-cation halide perovskite films $\mathrm{MaPbI}_{3}$ upon the addition of different amounts of Antisolvent diethyl ether. It can be observed that the surface 
morphology contained the irregular size of the grain boundaries of thin films. As shown in figure. 6.5 (a, b, c and d) upon the addition of $1 \mathrm{ml}, 2 \mathrm{ml}, 2.5 \mathrm{ml}$ and $3 \mathrm{ml}$ diethyl ether respectively. Furthermore, the addition of diethyl ether $3 \mathrm{ml}$ makes the films surface flatter with the reduction of grain boundary in size. Furthermore, for the surface morphology improvement, the sample of $2.5 \mathrm{ml}$ antisolvent diethyl ether was thermally annealed with two different processes rapid and slowly [11,12]. It can be clearly observed from the morphology in Figure 6.5 ( $\mathrm{a}$ and $\mathrm{b}$ ). the process is shown in the schematic diagram in figure 6.6 wherein the rapid addition of antisolvent can enhance the homogeneity of the surface and formed small crystal in size Fig 4 (a). On the other hand, by the slow addition of antisolvent it reduces the solubility of the solute and consequently to generates the supersaturation $[13,14]$ to accelerate the crystallization process figure 6.6. Moreover, thermal annealing plays an important role on the surface and the crystallography of the films. In figure 6.6 (a) annealed at $60{ }^{\circ} \mathrm{C}$ for $5 \mathrm{~min}$ and (b) gradually temperature increases at $100^{\circ} \mathrm{C}$ for $10 \mathrm{~min}$. it is observed from the results that the crystal and grain size are significantly increase with annealing temperature.

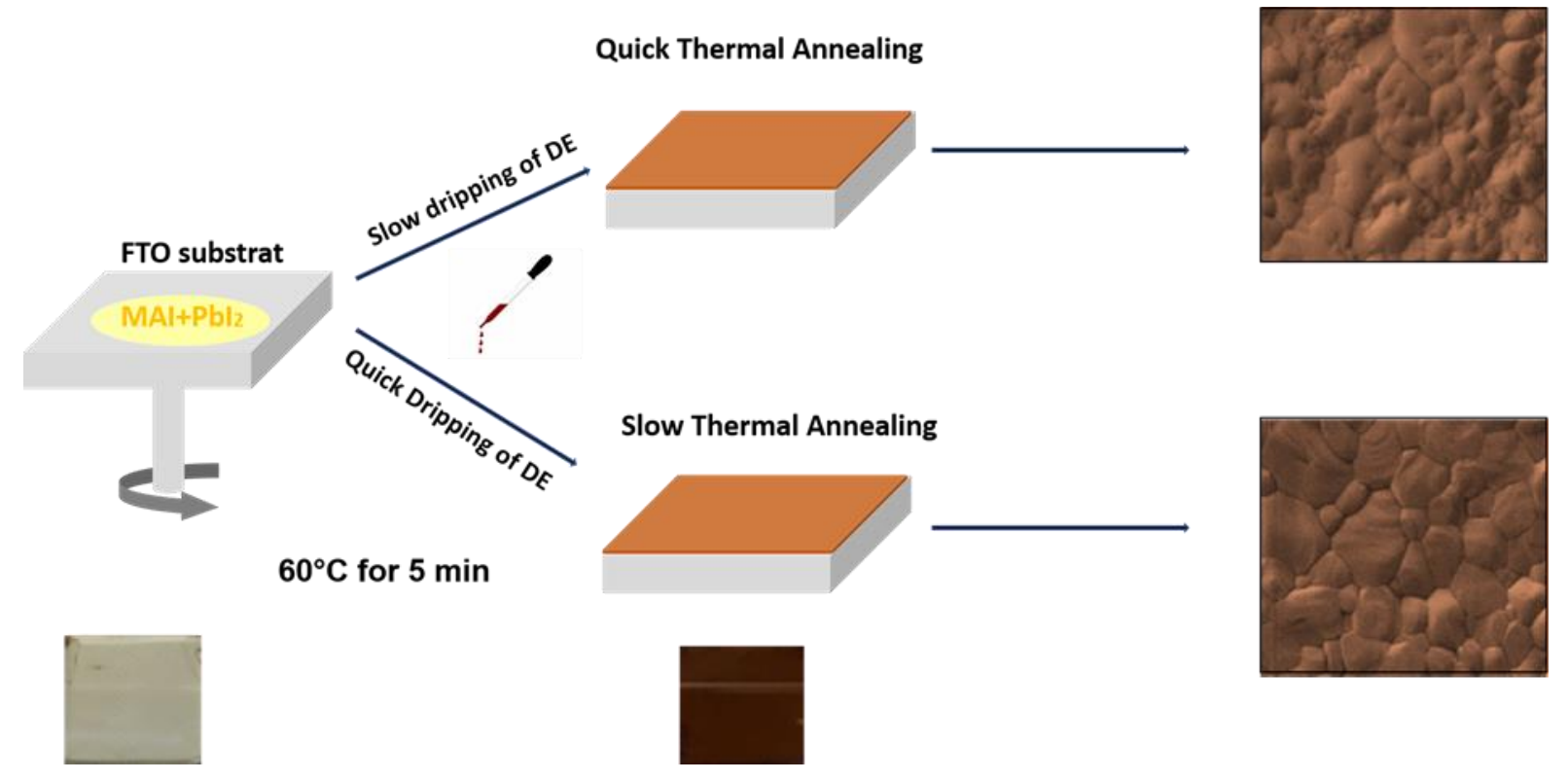

Figure 6.6. A schematic representation of two step antisolvent additions.

Figure 4.7 (c) showing A transmission electron microscopy (TEM) analysis of $\mathrm{MAPbI}_{3}$ thin film monocrystalline with lattice fringe spacing of $0.28 \mathrm{~nm}$ corresponding to (110) or (220) of the tetragonal $\mathrm{MAPbI}_{3}$ phase. This result was already confirmed by the XRD pattern (fig 1 a) where figure 4.7 (c) shows the selected area of electron diffraction (SAED) spectrum revealed that the $\mathrm{MAPbI}_{3}$ thins films are polycrystalline [15]. 

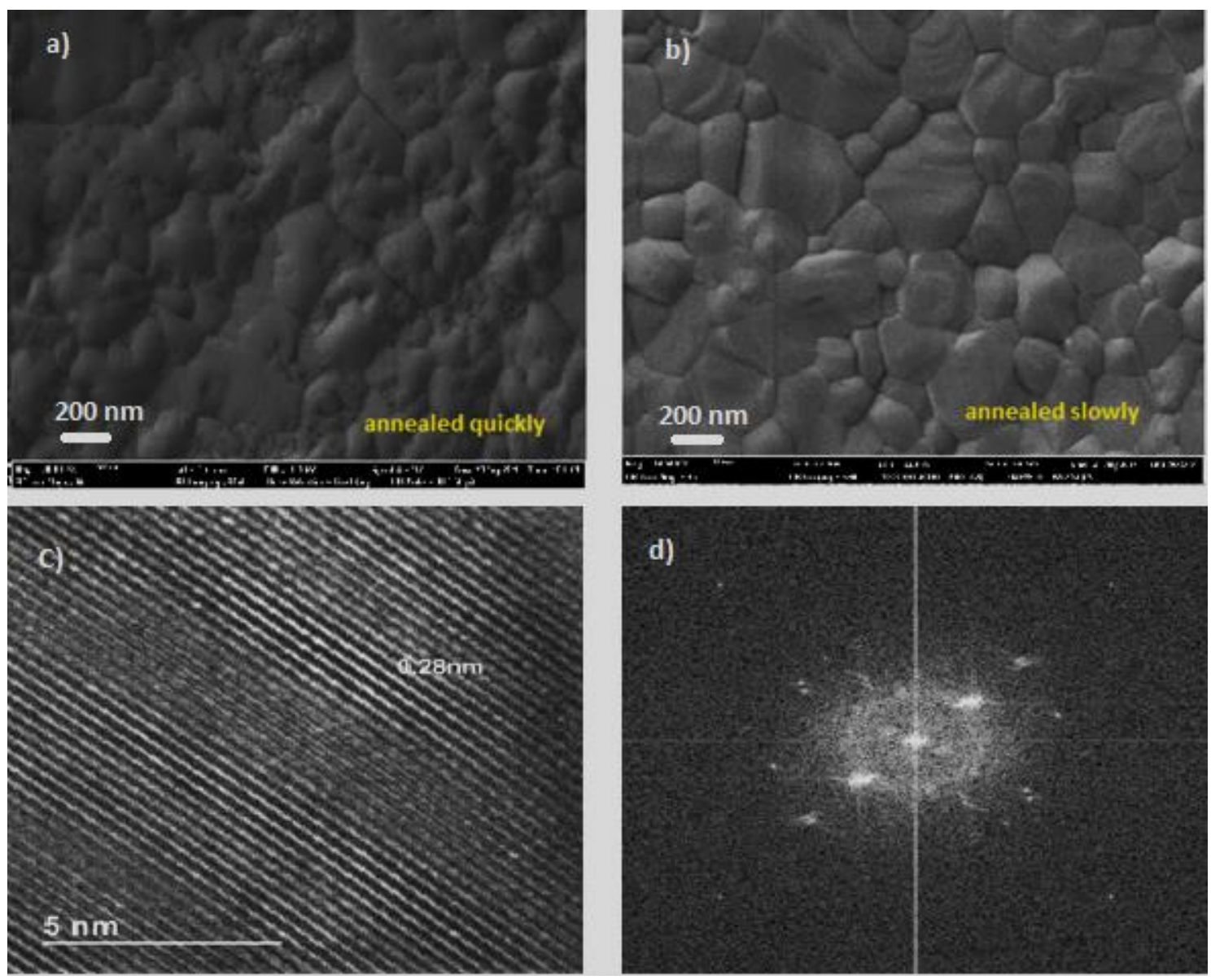

Figure 6.7. a, b) SEM images rapid and slow thermal annealing for $60 \mathrm{~min}$ and $100 \mathrm{~min}$ respectively, c) HRTEM images and d) SEAD of the interface.

Figure 6.8 represents the AFM analysis of $\mathrm{MAPbI}_{3}$ an area of $2 \mu \mathrm{m} \times 2 \mu \mathrm{m}$ treated by different ether additives $(1 \mathrm{ml}, 1.5 \mathrm{ml}, 2.5 \mathrm{ml}$ and $3 \mathrm{ml})$, The surface morphology and roughness are varying, which is calculated by the root-mean-square $\left(R_{\mathrm{rms}}\right)$ shows a dramatic change $39 \mathrm{~nm}, 41 \mathrm{~nm}$ and 46.73 $\mathrm{nm}$ for diethyl ether $1 \mathrm{ml}, 1.5 \mathrm{ml}$ and $2.5 \mathrm{ml}$ respectively. The obtained results are summarized in Table 6.1. On the other hand, the $R_{\mathrm{rms}}$ decreases to $36.99 \mathrm{~nm}$ by the addition of $3 \mathrm{ml}$ diethyl ether fig. $5 \mathrm{~d}$. Although the use of $2.5 \mathrm{ml}$ of diethyl ether shows strong absorption from the visible to near infrared region. There are large size of hills and troughs which makes the surface rougher in the AFM analysis. The morphology is correlated to the amount of diethyl ether until a certain point at which the surface roughness started to decrease in size. 
a) MaPbl-ET-1ml

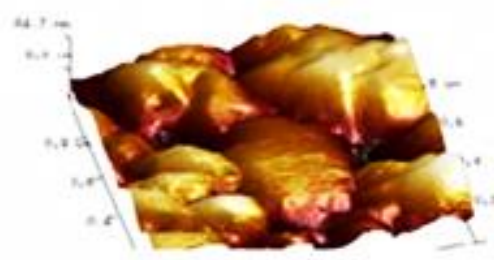

c) MaPbl-ET-2.5ml

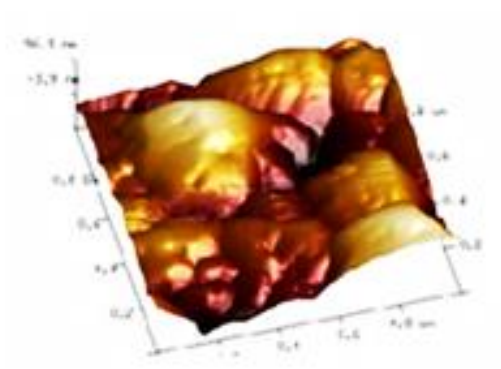

b) MaPbI-ET-2ml
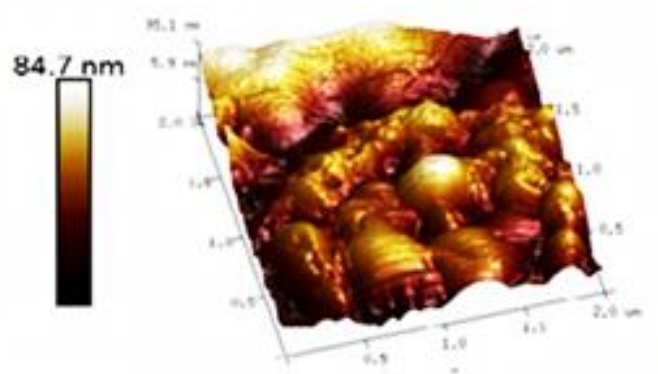

d) MaPbl-ET-3ml

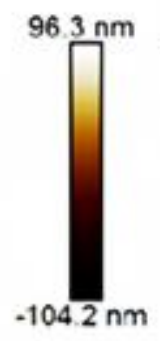

$200 \mathrm{~nm}$

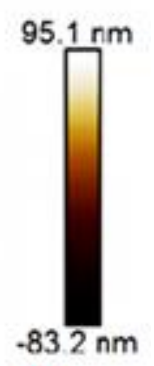

$200 \mathrm{~nm}$

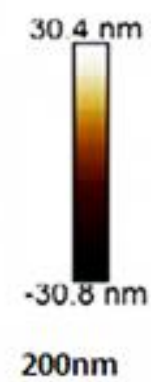

Figure 6.8. AFM images of perovskite multiple-cation halide perovskite films $\mathrm{MaPbI}_{3}$ upon addition of different amounts of Antisolvent diethyl ether.

\subsection{Optical properties of $\mathrm{MAPbI}_{3}$ perovskite films.}

The photoluminescence (PL) measurement is recorded ambient temperature is shown in Figure. 6.9 a. It is observed that the obtained PL peak intensity in the range of 700- $850 \mathrm{~nm}$ reported before [16] gradually increases with an increasing amount of diethyl ether. However, by addition more than $2.5 \mathrm{ml}$ of diethyl ether the PL intensities start inverse change. Suggestion that the diethyl ether $2.5 \mathrm{ml}$ is the optimal level for where it can trap more light. this result also supports the morphology and the crystal quality improvement of perovskite thin films. The corresponding UV-vis spectra of $\mathrm{MAPBI}_{3}$ were recorded between $400 \mathrm{~nm}$ and $900 \mathrm{~nm}$ Fig. 6 b. it can be clearly observed that different diethyl ether concentration shift the absorption edge to the high wavelength. The most obvious the absorption shift due to improvement of the crystallinity and surface passivation, which reduces defect density of the $\mathrm{MAPBI}_{3}$ films and increase crystallization quality. Furthermore, the optical bandgap is a good agreement where the bandgap dramatically decrease until an optimal level Figure $6.9 \mathrm{c}$. The diethyl ether antisolvent regulate the optical properties of $\mathrm{MAPBI}_{3}$ semiconductors materials for photovoltaic device $[17,18,19]$. The optical bandgap and corresponding wavelength are summarized in Table 6.2. 

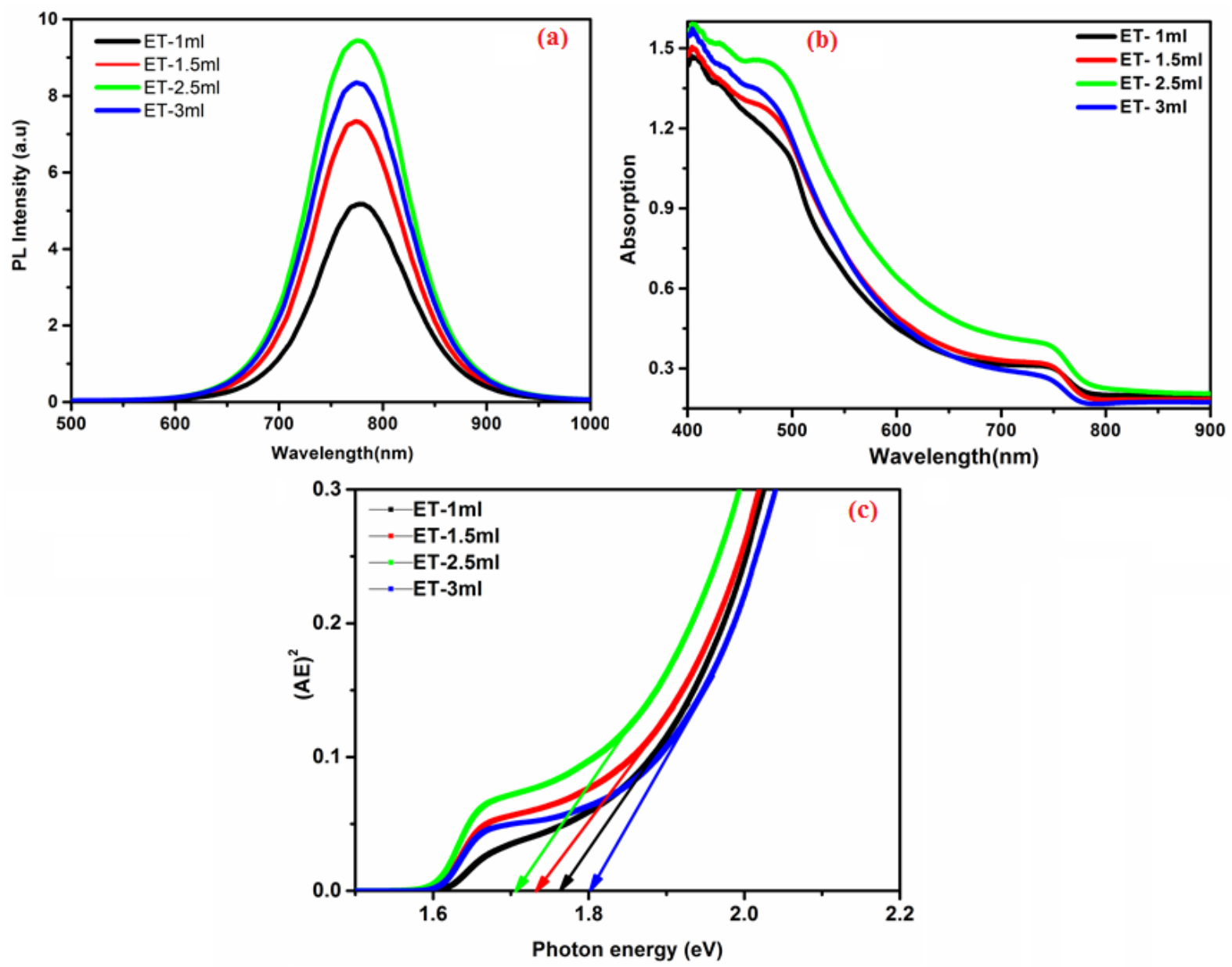

Figure 6.9 a) $\mathrm{PL}$ perovskite thin films $\mathrm{MaPbI}_{3}$ upon addition of different amounts of Antisolvent diethyl ether b) UV-vis absorption and c) Optical bandgap of $\mathrm{MaPbI}_{3}$.

Table 6.2: Band gap of the $\mathrm{MAPbI}_{3}$ thin films with different amounts of antisolvent diethyl ether.

\begin{tabular}{|c|l|l|l|l|c|}
\hline \multirow{2}{*}{ Sample.ID } & \multicolumn{2}{|l|}{ PL } & \multicolumn{2}{|c|}{ Absorption } & $\begin{array}{c}\text { Stokes shift } \\
(\mathbf{m e V})\end{array}$ \\
\cline { 2 - 5 } ET-1ml & $\boldsymbol{\lambda} \mathbf{( n m )}$ & $\mathbf{E g}(\mathbf{e V})$ & $\boldsymbol{\lambda} \mathbf{( n m )}$ & $\mathbf{E g}(\mathbf{e V})$ & \\
\hline ET-1.5ml & 779 & 1.59 & 700 & 1.77 & 180 \\
\hline ET-2.5ml & 784 & 1.58 & 720 & 1.72 & 140 \\
\hline ET-3ml & 789 & 1.57 & 729 & 1.70 & 130 \\
\hline
\end{tabular}

\section{Degradation study of $\mathrm{MAPbI}_{3}$}

The environmental like oxygen and humidity are the two main factors that affect photovoltaic stability. Herein, we studied the degradation mechanism of $\mathrm{MAPbI}_{3}$ films deposited using the ET 
antisolvent treatment. Perovskite films were kept under dark conditions at $60 \%$. To evaluate the degradation of MA-samples, we examined the structural and morphological changes of the 2.5 ET$\mathrm{MAPbI}_{3}$ sample after 4 weeks. The degradation of the $\mathrm{MAPbI}_{3}$ is most probably initiated by the $\mathrm{H}_{2} \mathrm{O}$ molecules presented in the air, leading to the slow deterioration of the $\mathrm{MAPbI}_{3}$ lattice and therefore a change of the film color from dark black to brownish color as show in Figure 6.10.

Further we examined the surface of layer by the SEM Figure 6.11.a) and b) the morphology of the perovskite layer MAPbI-Et-2.5ml showed a granular and rather inhomogeneous topography and grain boundaries which is ideal for the study of the degradation process. Fig.6.11.c The XRD spectrum after 4 weeks is dominated by the strong $\mathrm{PbI}_{2}$ peak, indicating the decomposition of $\mathrm{MAPbI}_{3}$ structure to $\mathrm{PbI}_{2}$. The degraded yellow areas continued to grow until taking all over the film area after 4 weeks. Our results can serve to explain the rate of degradation and the origin of the enhanced performance and the stability [22][23][24].

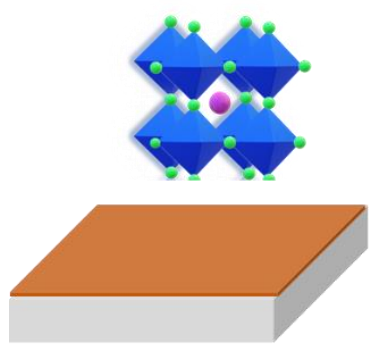

$60 \%$ Humidity under dark conditions

$$
\mathrm{CH}_{3} \mathrm{NH}_{3} \mathrm{I}_{3} \stackrel{\mathrm{H}_{2} \mathrm{O}}{\Longrightarrow} \mathrm{CH}_{3} \mathrm{NH}_{2}+\mathrm{PbI}_{2}+\text { other compositions }
$$
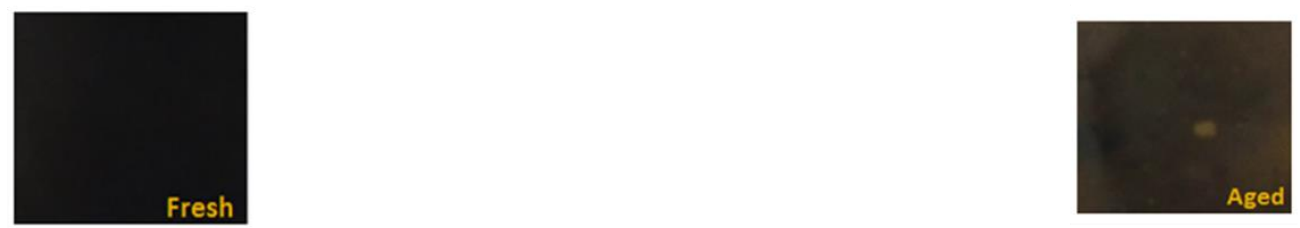

Figure 6.10. Degradation mechanism of $\mathrm{MAPbI}_{3}$ in air at $60 \%$ humidity under dark conditions. 

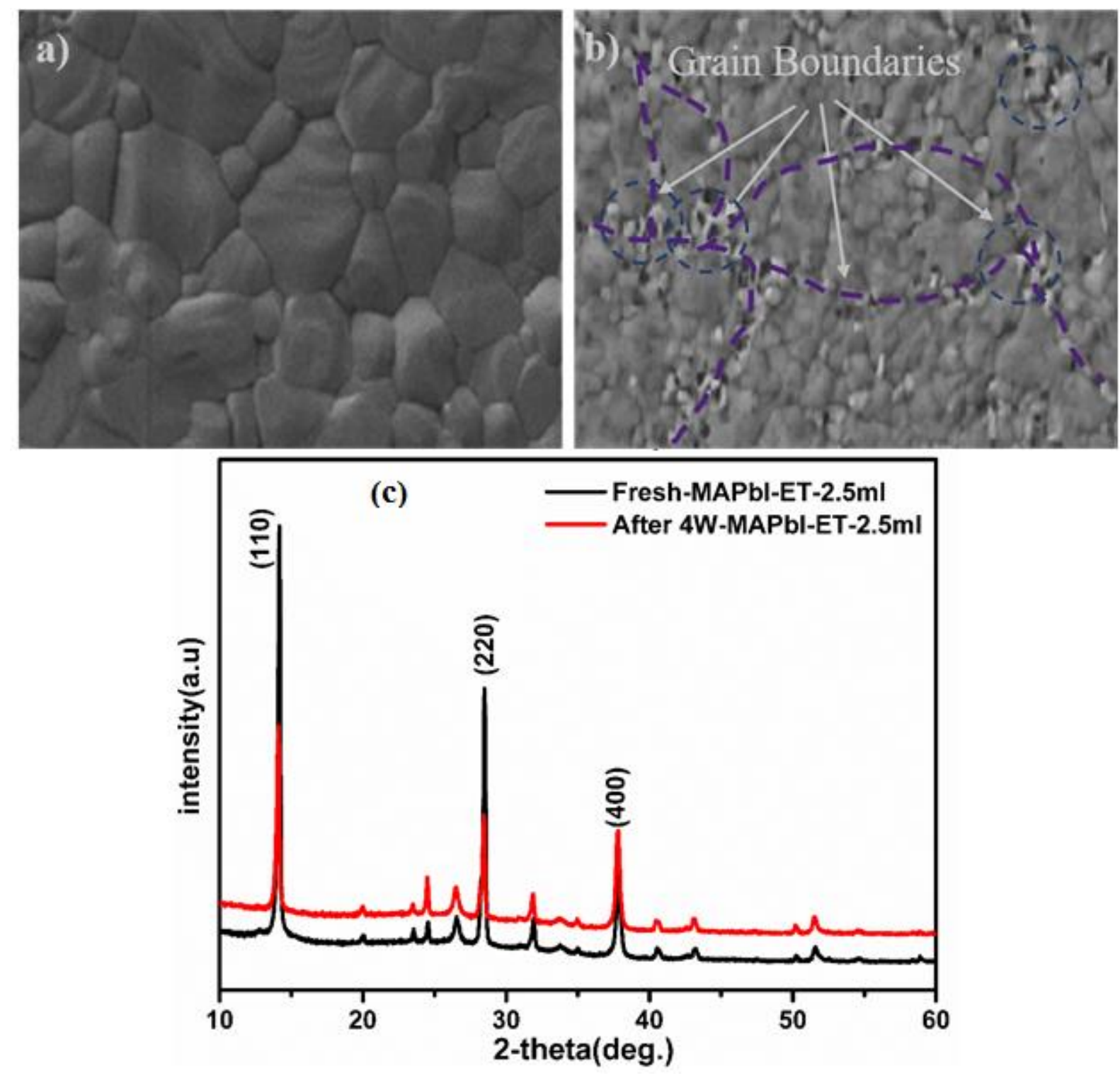

Figure 6.11. Degradation study of $\mathrm{MAPbI}_{3}$ at ET-2.5 ml (a) Fresh sample SEM image (b) aged sample after 4 weeks and (c) XRD pattern fresh and aged sample after 4 weeks 


\section{Methylammonium lead triiodide $\mathrm{MAPbI}_{3}$ doping by Tetrabutylammonium (TBA) Perovskites Thin films.}

In recent years the Perovskites type $\mathrm{ABX} 3$ where $\mathrm{A}$ is an inorganic or organic cation, $\mathrm{B}$ is a metal cation and $\mathrm{X}$ is a halogen anion where the furthermost common organic $\mathrm{A}$ cations are Methylammonium (MA: $\mathrm{CH} 3 \mathrm{NH}+3$ ) or Formamidinium (FA: $\mathrm{CH}(\mathrm{NH} 2)+2$ ). The B cations are generally $\mathrm{Pb} 2+$ or $\mathrm{Sn2}+$, while $\mathrm{X}$ anions originate from the group VII halides $\left(\mathrm{Br}^{-}, \mathrm{Cl}^{-}, \mathrm{I}^{-}\right.$, or a mixed composition of those) have been considered by several research groups as good absorbers for organic and inorganic hybrid solar cells with high efficiency [25][26][27[28]. especially that halide perovskites where $\mathrm{A}$ is $\mathrm{MA}, \mathrm{B}$ is $\mathrm{Pb}$ and $\mathrm{X}$ is I mean $\mathrm{MaPbI} 3$ have good optical and electrical properties such as adjustable bandgap $(1.5 \mathrm{eV}-1.4 \mathrm{eV})$ [29] and a high absorption coefficient (104$105 \mathrm{~cm}-1)$ [30][31] and remarkable photovoltaic properties as well as higher energy conversion energy $(\mathrm{PCE}=20 \%)[8][9]$. For elaborate perovskite thin films with high quality, many techniques have been used, among the most used there are single-step solution deposition is normally used because of the simple and low manufacturing costs [32], two-step solution deposition that simple to control and generally used for the elaboration of perovskites thin film [33] two-step vapor-assisted deposition [34], and thermal vapor deposition normally used for production high-quality thin layers with uniform thickness and composition [35]. in spite of the outstanding performance reported, $\mathrm{MAPbI}_{3}$ perovskite stability is one issues that make the utilization of $\mathrm{MAPbI}_{3}$ difficult. Under humid conditions and higher temperatures $\mathrm{MAPbI}_{3}$ destroys and forms $\mathrm{PbI}_{2}$ by the loss of MAI. In order to enhance the stability of $\mathrm{MAPbI}_{3}$ perovskite, recently reported $\mathrm{Cs}$ doping $\mathrm{MaPbI}_{3}$, have revealed huge potential to enhance PCE as well as solar cell stability under UV irradiance [36] Graphdiyne was doped in both PCBM and $\mathrm{ZnO}$ films of perovskite solar cells were significantly improved stability of perovskite solar cells [37] the improved chemical stability of $\mathrm{MaPbI}_{3}$ is testified by doping the divalent anion $\mathrm{Se} 2-$ in the form of $\mathrm{PbSe}$ in precursor solutions to increase the hydrogen-bonding-like interactions between the organic cations and the inorganic framework [38]. furthermore, some investigations have proved that $\mathrm{MAPbI}_{3}$ is less stable than $\mathrm{MAPbBr}_{3}$ in humidity environment. However, the $\mathrm{MAPbBr}_{3}$ absorption is not suitable enough for manufacture the solar cell [39].

Here we show how to improve stability and to overcome the instability problems of hybrid perovskites by doping the tetrabutylammonium iodide (TBA) can be incorporated to form $\mathrm{MAxTBA}_{(1-\mathrm{X})} \mathrm{PbI}_{3}$ perovskites which show new strategy to enhance the proprieties, stability and 
efficiency specially that the perovskites materials have flexibility of chemical substitution. in particular, we demonstrated that doped $\mathrm{MAPbI}_{3}$ with small amount of 5\% TBA improve the crystallinity and the $\mathrm{MA}_{0.95} \mathrm{TBA}_{0.05} \mathrm{PbI}_{3}$ thin film exhibits pinhole-free surface morphology, and enhanced optical properties.

\subsection{Film Preparation of $\mathrm{MAPbI}_{3}$ doped Tetrabutylammonium perovskite films}

Lead (II) iodide $\left(\mathrm{PbI}_{2}, 99.999 \%\right.$ for perovskite), Tetrabutylammonium iodide (TBAI), Chlorobenzene (CBZ, anhydrous, 99.8\%) and Methylammonium iodide (MAI), All compounds where been used without any supplementary purification, anhydro us N, N-dimethylformamide (DMF) and (DMSO) were obtained from Sigma-Aldrich. Precursor solutions of $\mathrm{MA}_{1-\mathrm{x}} \mathrm{TBA}_{\mathrm{x}} \mathrm{PbI}_{3}$ were elaborated by dissolving ratio TBAI: MAI and $\mathrm{PbI}_{2}$ in a mixed solvent containing of DMF: DMSO. Solutions prepared were stirred at $80{ }^{\circ} \mathrm{C}$ for 3 hours in glovebox filled with argon gas.

X-ray diffraction (XRD) were made on the RIGAKU Ultima IV diffractometer with a secondary graphite monochromator, XRD diaphragm's in the range $10^{\circ}$ to $60^{\circ} 2$ was done using Cuka radiation $(\lambda=1.5418 \AA)$ at room temperature. Scanning electron microscopy FE-SEM (Quanta 200 - FEI). The calculations conditions were done at $1.5 \mathrm{kV}$ in several magnifications. Atomic Force Microscopy(AFM) the measures were done by using NanoSurf Mobile S instrument in tapping mode). A voltage scan was performed to the cell from $-1.5 \mathrm{~V}-1.5 \mathrm{~V}$ at a scan rate of $0.5 \mathrm{~Hz}$. Transmission electron microscopy (TEM) (JEO-JEM-1010) with the measurement conditions were $2.5 \mathrm{kV}$ at numerous magnifications. Absorption measurements were applied using Ocean Optics HR4000 spectrophotometer a Si-CCD, between 300 to $850 \mathrm{~nm}$ wavelengths. Room temperature photoluminescence (RPL) measurements were achieved using a He-Cd laser source emitting at 325 nm and a back-thinned Si-CCD detector Hamamatsu detected the PL emission.

\subsection{Structural and morphological analysis of MAPbI3 doped Perovskite Thin Films}

The thin films $\mathrm{MaPbI}_{3}$ and $\mathrm{x} \%$ TBA: $\mathrm{MaPbI}_{3}$ were deposited on FTO substrates with $\mathrm{CBZ}$ as the antisolvent by the one-step spin-coating technique, we performed X-ray diffraction (XRD) of $\mathrm{x} \%$ TBA: $\mathrm{MaPbI}_{3}$ doped films to evaluate the effect of doping by tetrabutylammonium iodide in structure of $\mathrm{MAPbI}_{3}$ thin films. Figure 1 illustrates the XRD patterns of $\mathrm{MAPbI}_{3}$ doped with different amounts of $\mathrm{x} \% \mathrm{TBA}$ where $\mathrm{X} \%=(0 \%, 1 \%, 2.5 \%, 5 \%, 10 \%)$. The diffraction peaks positioned at $14^{\circ}, 28^{\circ}$, $31^{\circ}, 38^{\circ}, 31^{\circ}, 40.78^{\circ}$ and $43.18^{\circ}$, which agrees to the planes of (110), (200), (211), (202), (220), (310), 
(224) and (330) respectively where they are a representative of the $\mathrm{MAPbI}_{3}$ structure as it was reported [40][41].No binary $\mathrm{PbI}_{2}$ phase can be observed. The maximum XRD peak intensities of (110) and (220) of perovskite films are improved by doping with small amount (1\%) of TBA to double intensities with amount 5\%, representing well crystallization of the films. This is definitely lead to improving the opto-electronic properties of the $\mathrm{MAPbI}_{3}$ perovskite films. likewise, the zoomed in XRD peak between $10^{\circ}$ and $17^{\circ}$ between $10^{\circ}$ and $17^{\circ}$ and range $13.99^{\circ}$ to $28.1^{\circ}$ of doped $\mathrm{x}$ TBA shows very small shifts towards a Lower $2 \theta$ compared to pure MAPbI3, indicating an increase of the crystalline lattice which can be attributed to bigger ionic radius of $\mathrm{TBA}+(4.70 \AA)$ compared to MA (1.8 $\AA$ ). All perovskite films crystalize in a tetragonal and the lattice parameters were found to be $\mathrm{a}=\mathrm{b}=8.81 \AA, \mathrm{c}=11.22 \AA$ for pure $\mathrm{MAPbI}_{3}$ and with small change for $\mathrm{x} \% \mathrm{TBA}$ samples, the crystal structural details of $\mathrm{MAPbI}_{3}(\mathrm{x} \%=0,5,10)$ are extracted from Pawley refinements of XRD were recorded to calculate the lattice parameters and Grain size. Table 1. Further The full width at halfmaximum (FWHM) of peaks (110) and (220) is approximately 0.11 and 0.12 respectively, dictated by the good crystallinity due to effect of incorporating TBA, and indicating a highly grain size.

To explain the impact of doping $\mathrm{MAPbI}_{3}$ in stability, we suggest that the intensification of perovskite peak (110) by incorporating TBA could be accelerated $\mathrm{MAPbI}_{3}$ formation by increasing the transformation of $\mathrm{PbI}_{2}$ toward $\mathrm{MAPbI}_{3}$ perovskite and eliminated $\mathrm{PbI}_{2}$ presented in the perovskite film and subsequently the degree of degradation will be increase with less binary $\mathrm{PbI}_{2}$ phase. specially, as have been demonstrated that surface imperfections come from inorganized Pb atoms of $\mathrm{PbI}_{2}$ leads to less performance of perovskite solar cells. We suggest with TBA substitution it can be improved the stability of the perovskite films as it is been identified that $\mathrm{MAPbI}_{3}$ lean towards to degradation into $\mathrm{PbI}_{2}$ in externed conditions [42].

Table 6.3. Lattice parameters of $\mathrm{x} \% \mathrm{TBA}: \mathrm{MaPbI}_{3}$ via the Pawley method.

\begin{tabular}{|c|c|c|c|c|c|c|}
\hline Sample.ID & $\begin{array}{l}\mathbf{a}=\mathbf{b} \\
(\AA)\end{array}$ & $c(\AA)$ & $\begin{array}{l}\text { Grain Size } \\
(\mathbf{n m})\end{array}$ & $\begin{array}{l}\text { Roughness } \\
(\mathbf{n m})\end{array}$ & $\begin{array}{l}\text { Dislocation } \\
\text { density }(\mathrm{nm}-1)\end{array}$ & $\begin{array}{l}\text { Lattice } \\
\text { strain }(\varepsilon)\end{array}$ \\
\hline MAPbI3 & 8.90 & 11.12 & 308 & 39 & $1.04 \times 10^{-05}$ & 0.38 \\
\hline $5 \%$ TBA & 8.91 & 11.11 & 439 & 41 & $0.52 \times 10^{-05}$ & 0.39 \\
\hline $10 \%$ TBA & 8.99 & 11.13 & 413 & 46.73 & $0.61 \times 10^{-05}$ & 0.37 \\
\hline
\end{tabular}

The Raman spectroscopy was been Performed to get insight about the phase identification. the spectra of MaPbI3 pure or Sample 5\% TBA are dominated by mode $52 \mathrm{~cm}^{-1}$, the E1LO mode at $110 \mathrm{~cm}^{-1}$ and E1LO $\left(340 \mathrm{~cm}^{-1}\right)$ assigned to crystalline phase, which is the main vibrational band of the MAPbI3 
phase. Figure describes the Raman spectra evolution induced by make the measurement of the 5\% TBA: MAPbI3 samples. The two distinct bands at 52 and $110 \mathrm{~cm}^{-1}$ become stronger with incorporation of TBA [43].
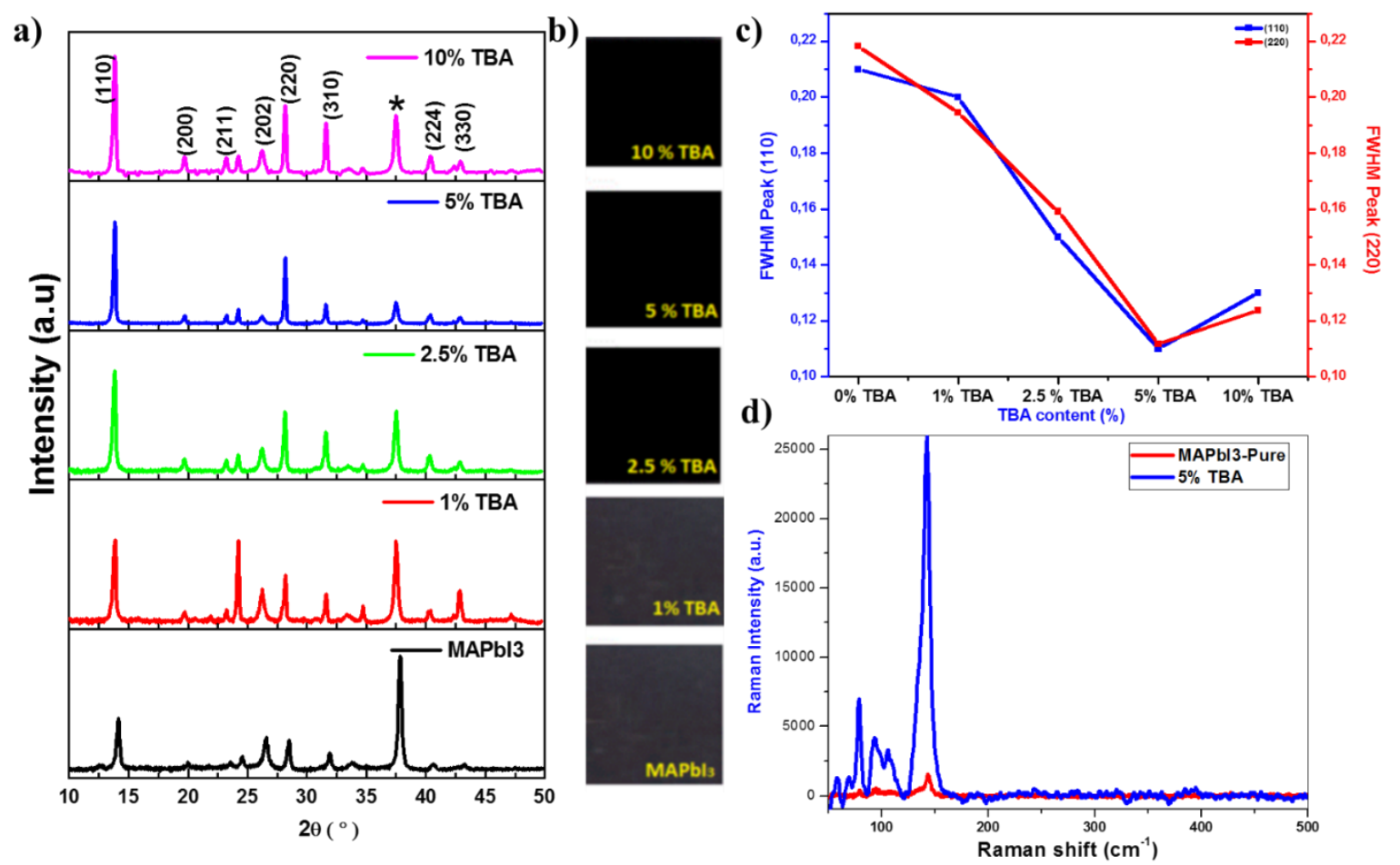

Figure 6.12 a) XRD pattern of spin coated $\mathrm{MAPbI}_{3}$ films with different amounts of $\left.\mathrm{TBA}, \mathbf{b}\right) \mathrm{MAPbI}_{3}$ photographs c) FWHM of peaks (011) and (022), c) Raman spectra of $\mathrm{MaPbI}_{3}$ and 5\% TBA. 

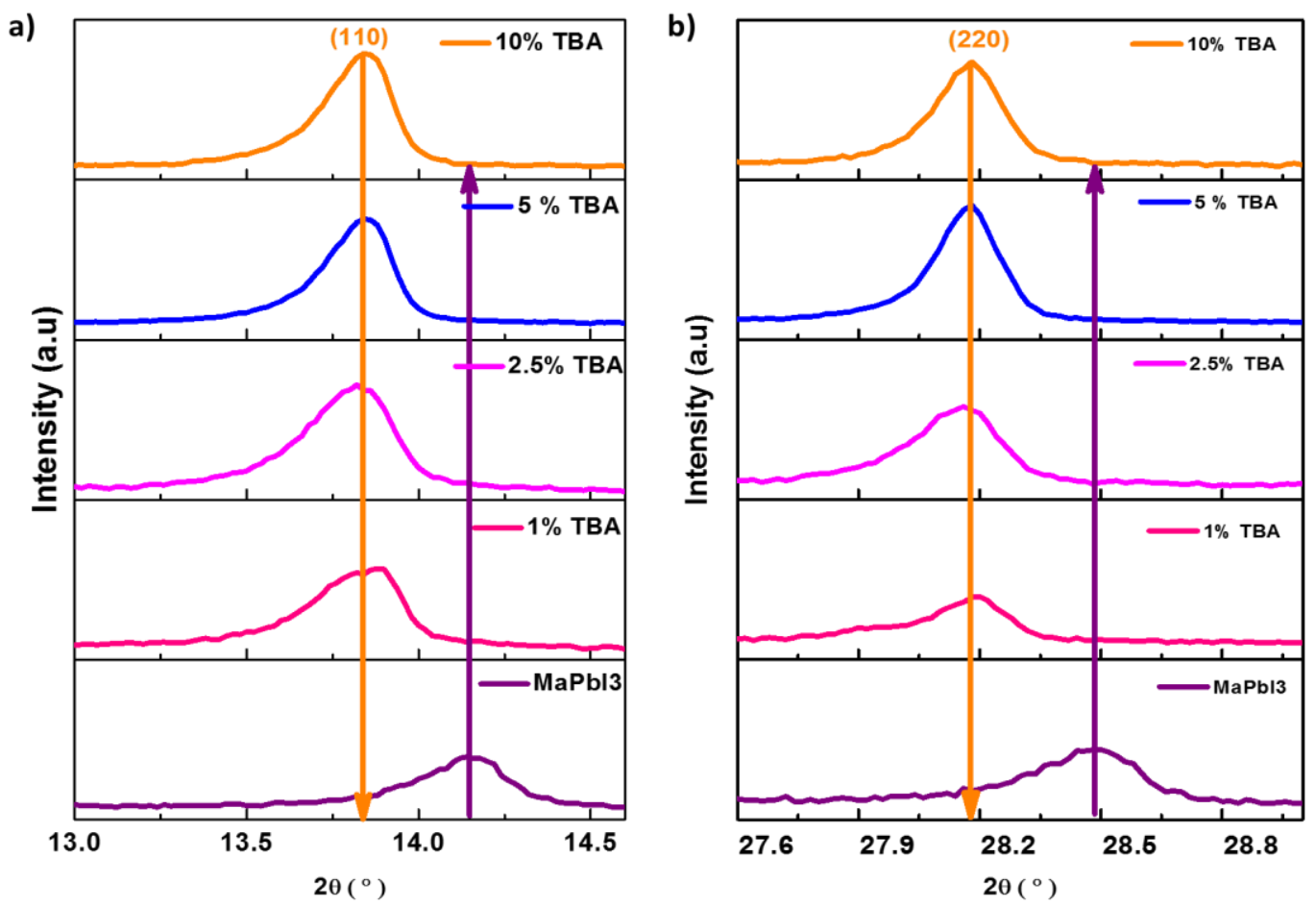

Figure 6.13 Shift of (110) and (220) XRD peaks of $\mathrm{MAPbI}_{3}$ perovskite after doping with different amount.

The SEM analysis was carried to examine the impact of TBA incorporation on the morphology SEM images of $\mathrm{x} \% \mathrm{TBA}: \mathrm{MAPbI}_{3}$ perovskite films are shown Figures $\mathrm{x}$ with diverse percent of TBA: $0 \%, 1 \%, 2.5 \%, 5 \%, 10 \%$. The $\mathrm{MAPbI}_{3}$ film demonstrate a relatively smooth surface and the crystals are formed in a small size, EDS Mapping of $\mathrm{MAPbI}_{3}$ confirms the uniform distribution of I and $\mathrm{Pb}$ elements [22]. Upon incorporation of only with $1 \%$ of TBA element, there is a little change in the surface and the crystals are slightly larger and the grains are clear figure 3.b. with $2.5 \%$ of TBA, the quality of the film seems to be better by the increase of the grain size about $490 \mathrm{~nm}$ and the loss of the pinholes, However, significantly altered the morphology with a percentage of 5\% with a grain size of $400 \mathrm{~nm}$ (Figure 3.c). The largest crystal size was found with 5\% TBA, while for the $10 \%$ TBA, there is an inhomogeneity between the grains size. The grain size progressively improved with TBA incorporation from $0 \%$ to $10.0 \%$ amount. The grain size was measured about $210 \mathrm{~nm}$ of undoped $\mathrm{MAPbI}_{3}$ sample, $290 \mathrm{~nm}$ for $1 \% \mathrm{TBA}, 490 \mathrm{~nm}$ for $2.5 \% \mathrm{TBA}$, and $500 \mathrm{~nm}$ of $5 \%$ TBA-doped samples. It is evident that the grain size progressively improved with TBA doped $\mathrm{MAPbI}_{3}$ from $0 \%$ to $10.0 \%$ amount; specially that the increase of the grain size effects directly the diffusion length and the charge carrier recombination rate [44]. 
The main reason of the increase of the grain size with doping TBA is due to the modulation of the crystal growth by reducing crystal nucleation and growth rate, leading to high crystallinity as indicated by XRD results, and good surface coverage. The addition of TBA increases the rate of crystalline grains and suppresses the formation of dense nuclei, hence obtaining larger grains, as shown in Figure 6.14 [45]. Better film quality and excellent grains crystallinity mean fewer defects and trap states, which can decrease the nonradiative recombination at the surface of $\mathrm{MAPbI}_{3}$. Different studies have reported the impact of surface/grain boundary passivation on the reduction of non-radiative loss in perovskites materials [46]. In conclusion, Small grain size directly related with the large numeral of grain boundaries in the thin, these positions act as charge trap sites, furthermore, they are disposed to attack by water molecules and these will accelerate degradation of the perovskite which is not the case with TBA doped $\mathrm{MAPbI}_{3}$ with large grain size.
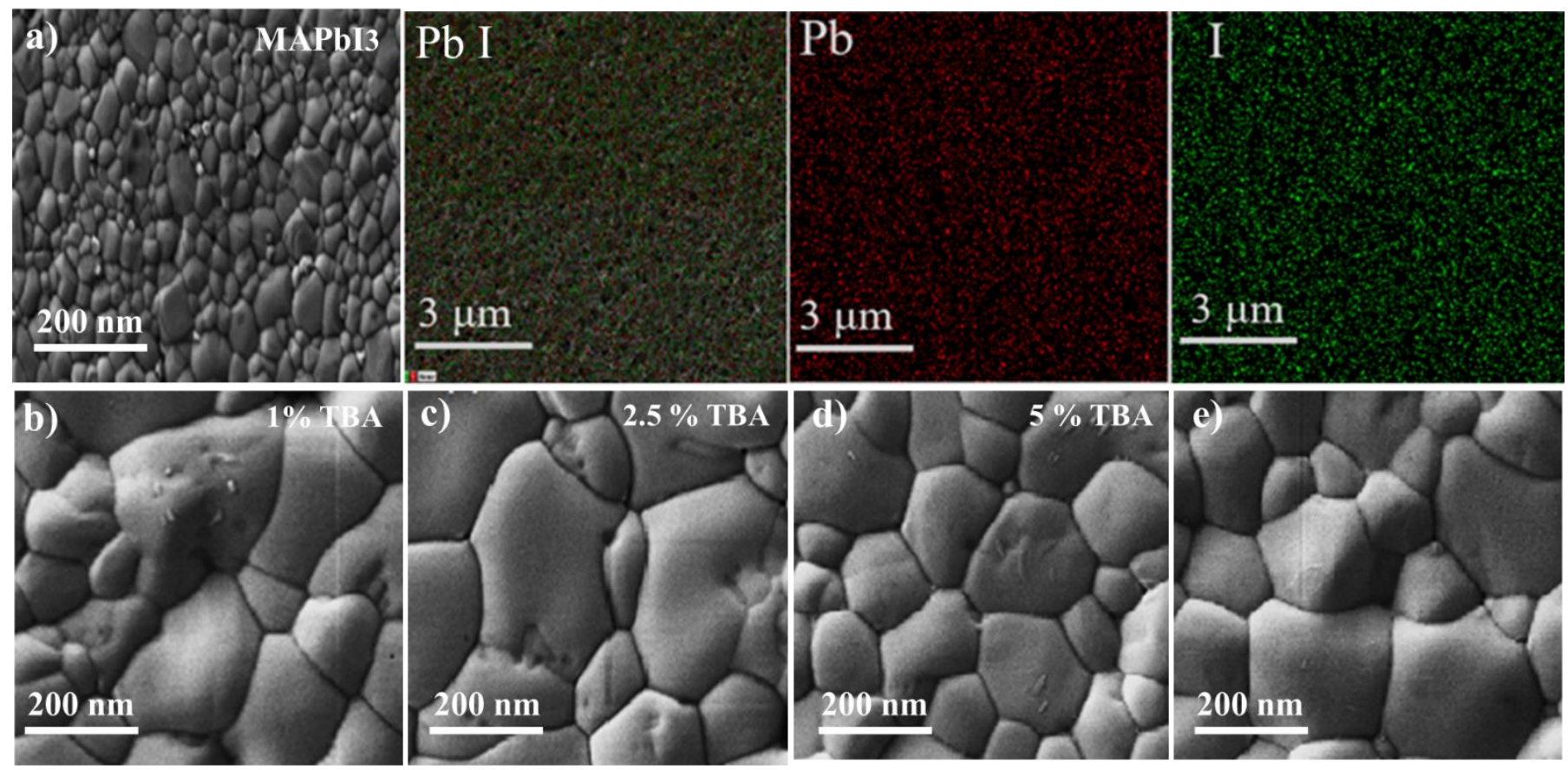

Figure 6.14 a) EdS Mapping of $\mathrm{MAPbI}_{2}$ with showing the map distribution of $\mathrm{Pb}$, I elements. b) Top-view SEM images of the $\mathrm{MAPbI}_{2} \mathrm{Br}$ film with different amounts of TBA
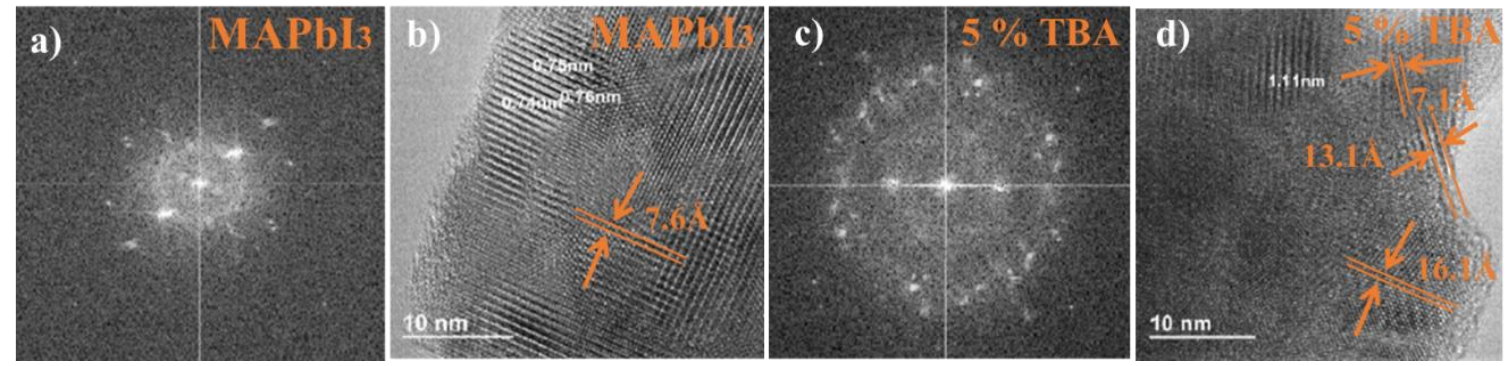
Figure 6.15 HRTEM Images of $\mathrm{MAPbI}_{3}$ films. The interplanar spacing of $0.76 \mathrm{~nm}$ and 1.31 corresponding of the (220) and (110) planes of 3D perovskites was observed.

Figure 6.12 display a transmission electron microscopy (TEM) analysis of $\mathrm{MAPbI}_{3}$ and $5 \%$ TBA sample reveal the monodispersed with lattice fringe spacing of $7.8 \AA$ and $11.1 \AA$ corresponding to (110) or (220), This result was previously confirmed by the XRD pattern (fig 1 a) where shows the selected area of electron diffraction (SAED) spectrum exposed that the $\mathrm{MAPbI}_{3}$ thins films are polycrystalline $[46,47]$.

Figure 6.16 represents the AFM analysis 2D and 3D of $\mathrm{MAPbI}_{3}$ perovskite thin films an area of $2 \mu \mathrm{m} \times 2 \mu \mathrm{m}$ prepared with different percentages of TBA $(\mathrm{X}=0 \%, 1 \%, 2.5 \%, 5 \%$ and $10 \%)$, The surface morphology and roughness are varying, which is calculated by the root-mean-square $\left(R_{\mathrm{rms}}\right)$ shows a dramatic change $39 \mathrm{~nm}, 49 \mathrm{~nm}$ and $50.73 \mathrm{~nm} \mathrm{0 \% ,1 \% ,2.5 \% ,5 \%} \mathrm{and} \mathrm{10 \%} \mathrm{respectively.} \mathrm{The}$ obtained results are summarized in Table 6.3. On the other hand, the $\mathrm{R}_{\mathrm{rms}}$ decreases to $56.99 \mathrm{~nm}$ by doping with $10 \%$ the crystals are slightly larger and the grains are clear fig. $5 \mathrm{~d}$. Although the use of $5 \%$ of TBA shows large size of hills and troughs which makes the surface rougher in the AFM analysis. AFM analysis approves SEM results, which show the formation of aggregate crystals of different sizes [48].
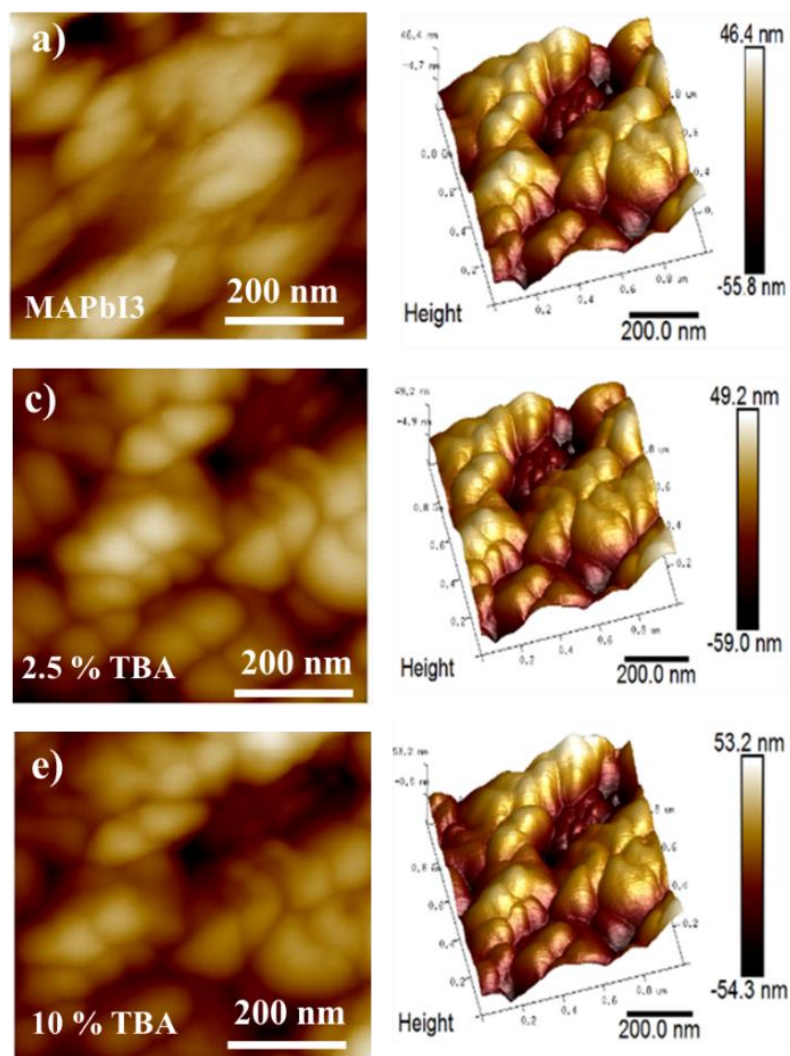
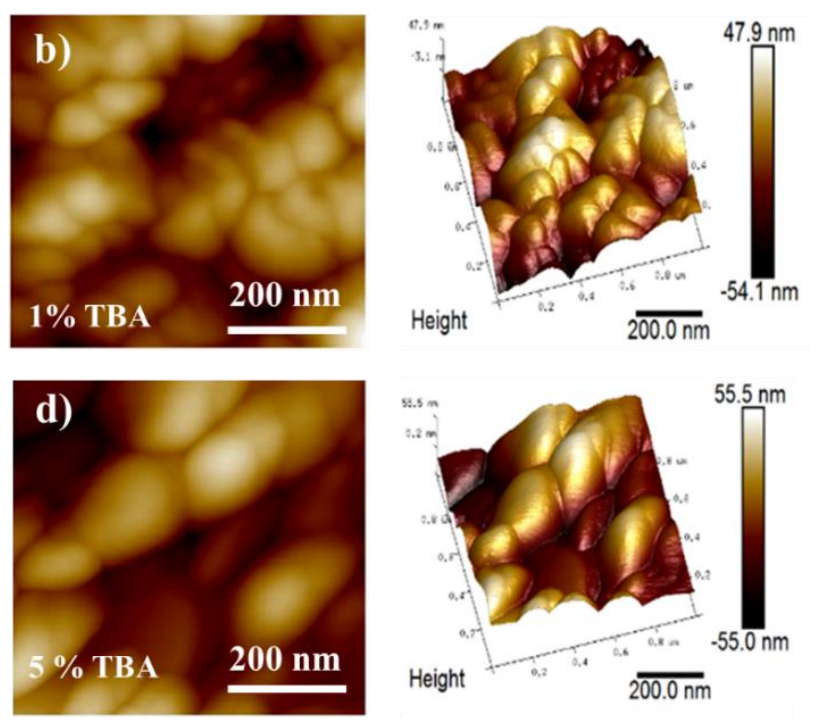
Figure 6.16 Top-view AFM images 2D and 3D of the $\mathrm{MAPbI}_{3}$ film with different amounts of TBA.

\subsection{Optical properties of $\mathrm{MAPbI}_{3}$ doped TBA perovskite films.}

We performed absorption and photoluminescence measurements to identify the effect of doping TBA on the opto-electronic properties of the $\mathrm{MAPbI}_{3}$ perovskite films, Figure 6.17 illustrate the absorption onset of TBA doped and undoped $\mathrm{MAPbI}_{3}$ is between 795-810 nm which implicate an optical bandgap around 1.87-1.89 eV. The absorption onset is not affected by doping MAPbI3 with $1 \%$ TBA. however, with 5\% TBA incorporation; a significant improvement of the film absorption was observed. the higher absorbance can be attributed to a good surface coverage and pinhole-free morphology of the 5\% TBA sample [49].

The figure 6.18 presented The PL spectrum shows an excellent Gaussian curve for the doped TBA that represents the excitonic emission intensity. The full width at half-maximum (FWHM) value progressively increases from TBA doped to undoped $\mathrm{MAPbI}_{3}$ when increasing TBA amount, for $5 \%$ TBA is around $55 \mathrm{~nm}$, demonstrating an extremely higher red emission, The improved PL emission of TBA doped $\mathrm{MAPbI}_{3}$ more 3 times compare to undoped $\mathrm{MAPbI}_{3}$ indicated the reduction of density of trap states which can be the main reason of the decrease of charge recombination which can improve the opto-electric properties [50,51].

The Stokes shift is interesting parameters in semiconductors since it suggests that the emission and band edge absorption state it is not totally similar. The very small Stokes shift between the absorption edge and the PL peak have been observed Table 6.4, in recent studies on the spectral properties the presence of a Stokes shift in $\mathrm{MAPbI}_{3}$ perovskite was explained by the relaxation of the crystals lattice parameters, in our case the low stoke value calculated provide important insight about the good photo physics film proprieties, In turn, it can enhance the efficiency of solar cells [52].

Table 6.4 Band gap variation according to TBA content.

\begin{tabular}{|l|c|c|c|c|c|}
\hline & \multicolumn{4}{|l|}{ PL } & \multicolumn{2}{l|}{ Absorption } & Stokes shift \\
\cline { 2 - 6 } Sample.ID & $\boldsymbol{\lambda} \mathbf{( n m )}$ & $\mathbf{e V}$ & $\boldsymbol{\lambda} \mathbf{( n m )}$ & $\mathbf{e V}$ & $\mathbf{m e V}$ \\
\hline MAPbI3 & 779 & 1.59 & 750 & 1.81 & 220 \\
\hline 5\% TBA & 787 & 1.57 & 760 & 1.75 & 220 \\
\hline 10\% TBA & 787 & 1.57 & 762 & 1.77 & 200 \\
\hline
\end{tabular}



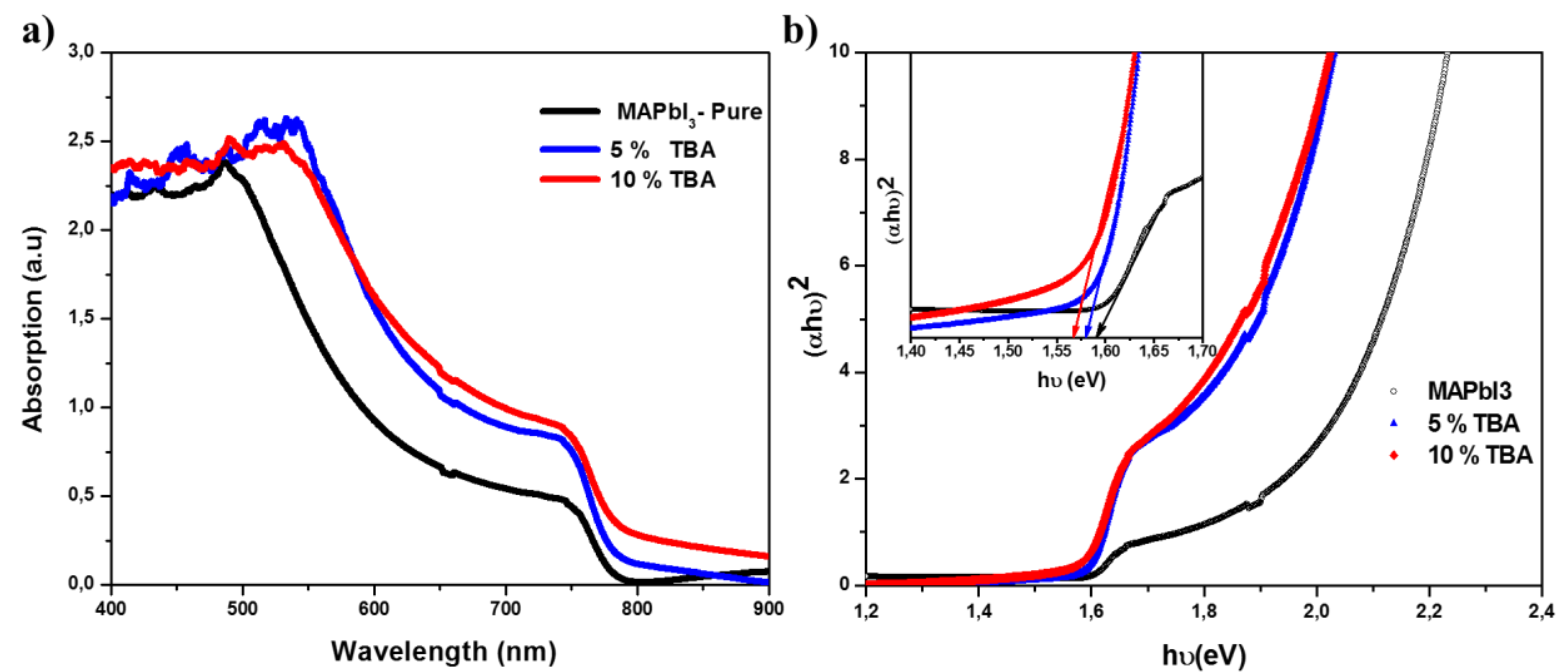

Figure.6.17 a) Absorbance spectra of undoped and TBA doped $\mathrm{MAPbI}_{3} \mathrm{FTO}$ b) band gap spectra of undoped and TBA doped $\mathrm{MAPbI}_{3}$
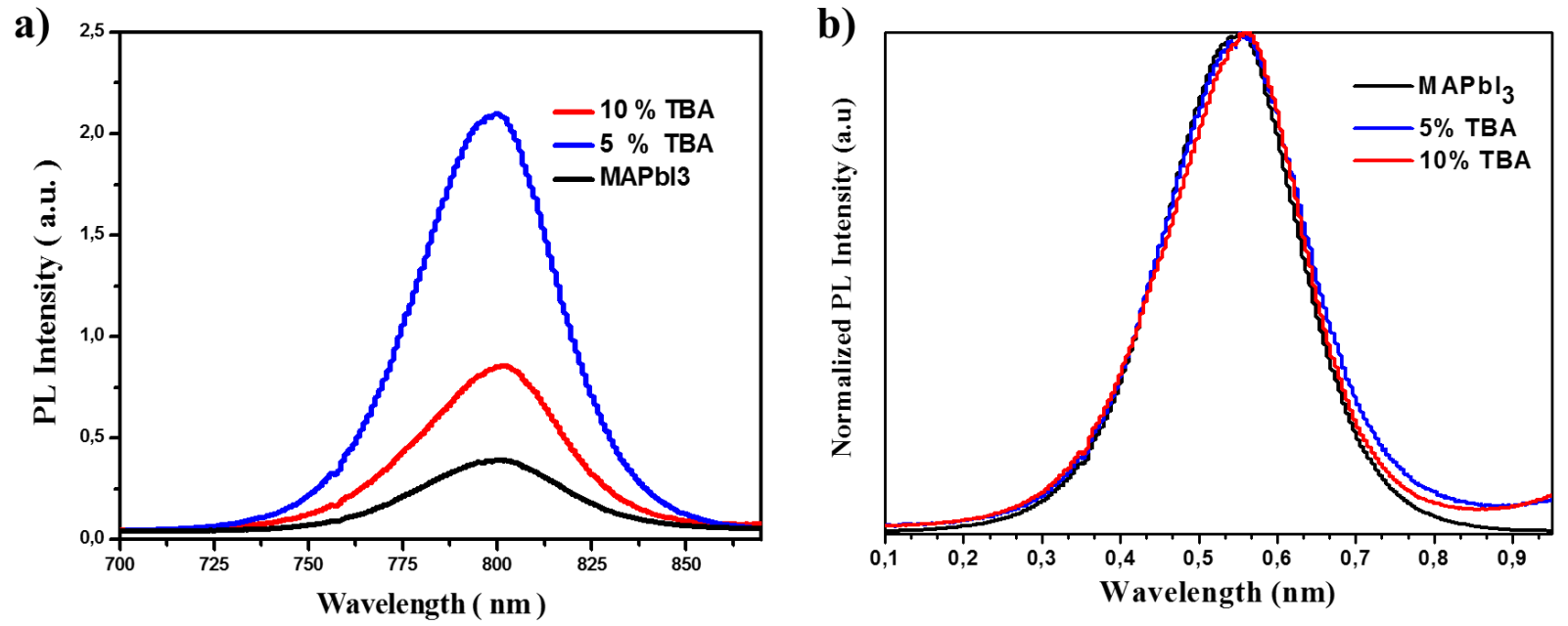

Figure 6.18 a) PL spectra of TBA doped and undoped $\mathrm{MAPbI}_{3}$ thin film b) normalized PL spectra of TBA doped and undoped $\mathrm{MAPbI}_{3}$ thin film

\section{Degradation study of $\mathrm{MAPbI}_{3}$ doped TBA:}

The stability of the TBA doped and undoped $\mathrm{MAPbI}_{3}$ films was examined. The 5\% TBA and $\mathrm{MAPbI}_{3}$ films were stored at dark under $60 \%$ relative humidity for 15 days to evaluate the degradation of the samples. Figure 6.20 shows photographs of the fresh and aged films TBA doped and undoped $\mathrm{MAPbI}_{3}$ as it was expected a significant transformation from the black perovskite color to the non- 
perovskite brown color was observed for undoped $\mathrm{MAPbI}_{3}$ after 15 days in other hand doped was less affected and show some yellow holes.

The SEM images illustrate the degradation of the undoped $\mathrm{MAPbI}_{3}$ start at unique sites on the surface of the films before taking up the entire surface, the water molecules interact with the perovskite materials over the grain boundaries, which leads to the dissociation of the perovskite structure to form a yellow non perovskite phase. With the introduction of 5\% TBA, the perovskite grains become larger, which reduce the grain boundaries and therefore prevents the entry of moisture into the $\mathrm{MAPbI}_{3}$ film. Furthermore, doping has been reported to induce slight distortion of the perovskite crystal structure $[53,54]$.
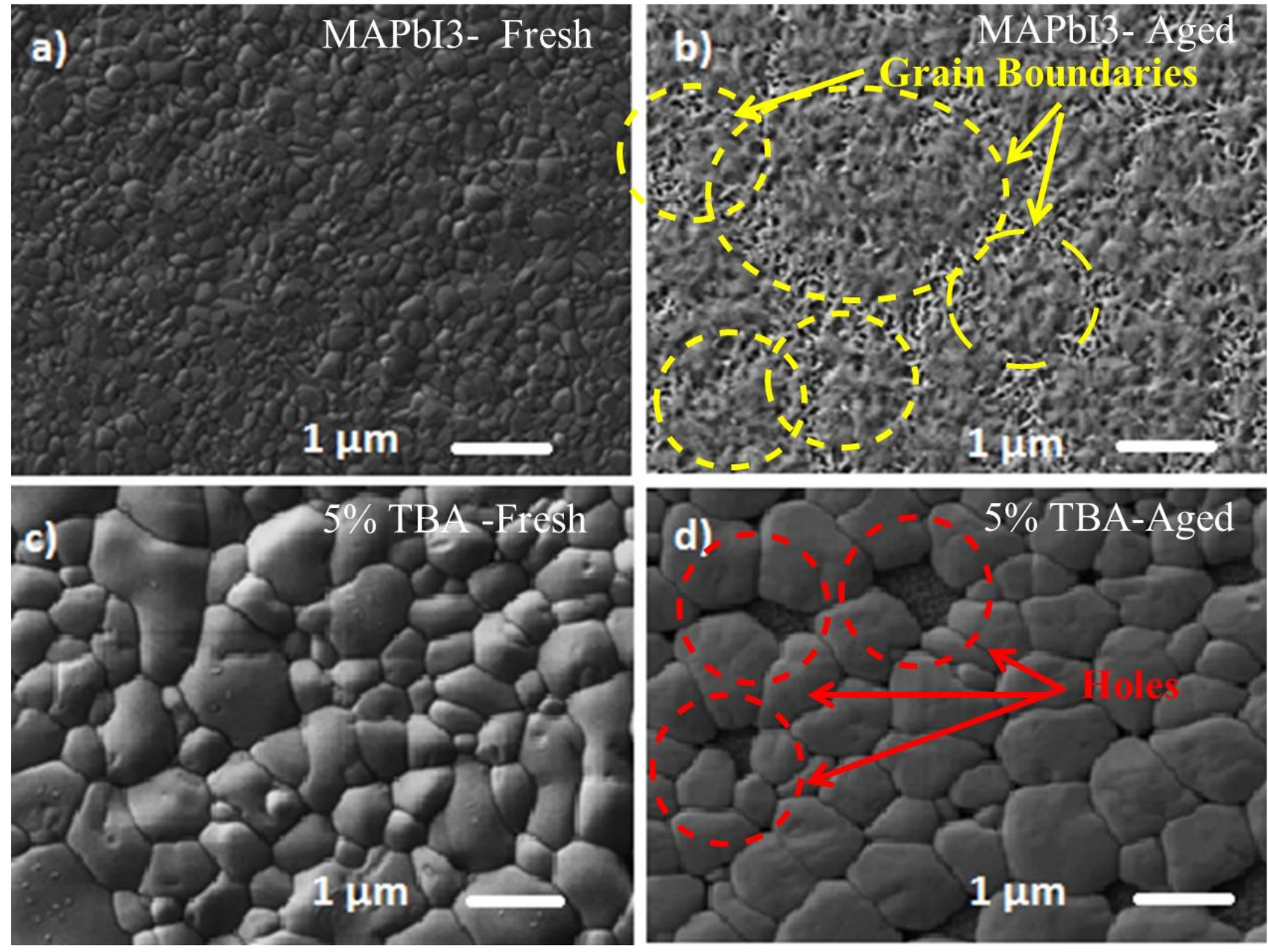

Figure 6.19 Top-view SEM images fresh, aged $\mathrm{MAPbI}_{3}$ and 10\% TBA films kept in Argon and in a humid air 
the X-ray diffraction (XRD) patterns in figure 6.20 shows the structural changes during degradation of the films where the characteristic peak (110) of undoped $\mathrm{MAPbI}_{3}$ shows dramatical decrease though slow change for 5\% TBA doped $\mathrm{MAPbI}_{3}$.
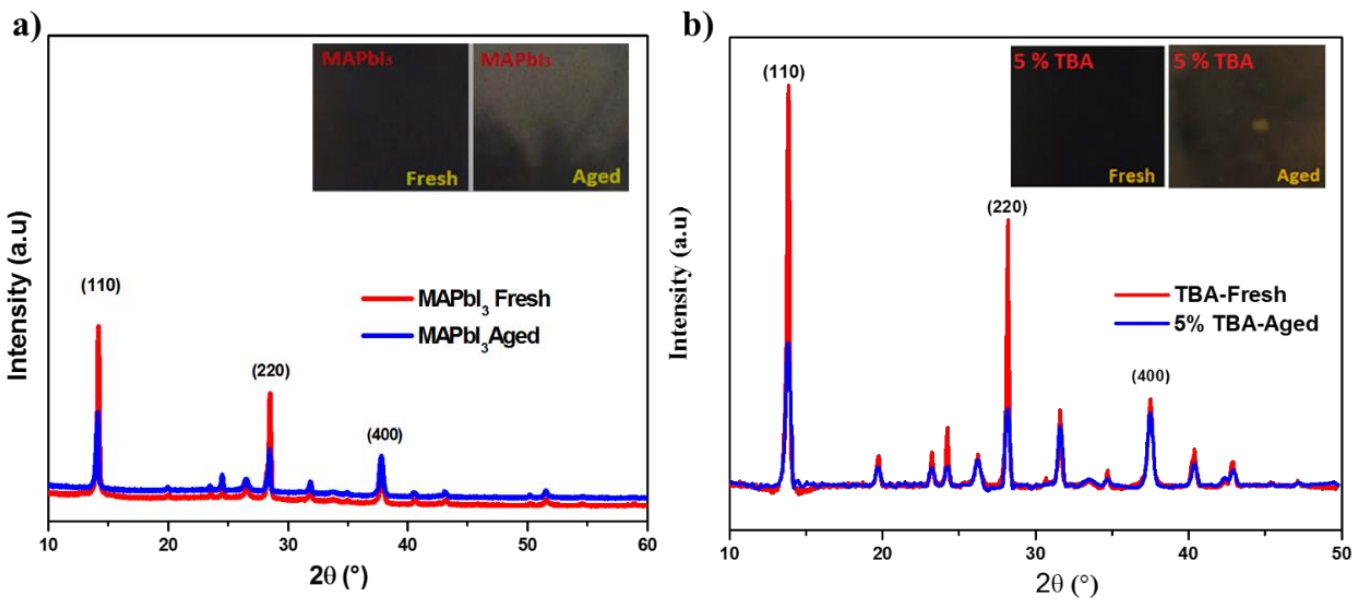

Figure 6.20 XRD fresh, aged $\mathrm{MAPbI}_{3}$ and $5 \%$ TBA films kept in Argon and in a humid air.

To get more insights into the doped $\mathrm{MAPbI}_{3}$ degradation in humid environments, the very slow degradation of 5\% TBA doped MAPbI3 sample is studied by the UV-Vis spectroscopy. Figure 6.21 shows a slow diminution of the absorbance edge of 5\% TBA. This variation is correlated with a color change of the films color from dark brown to orange brown after two weeks as shown in photographs. Hence, our results suggest that the incorporation of a small amount of TBA can enhance the stability of perovskite structure of $\mathrm{MAPbI}_{3}$ [55-58]. 


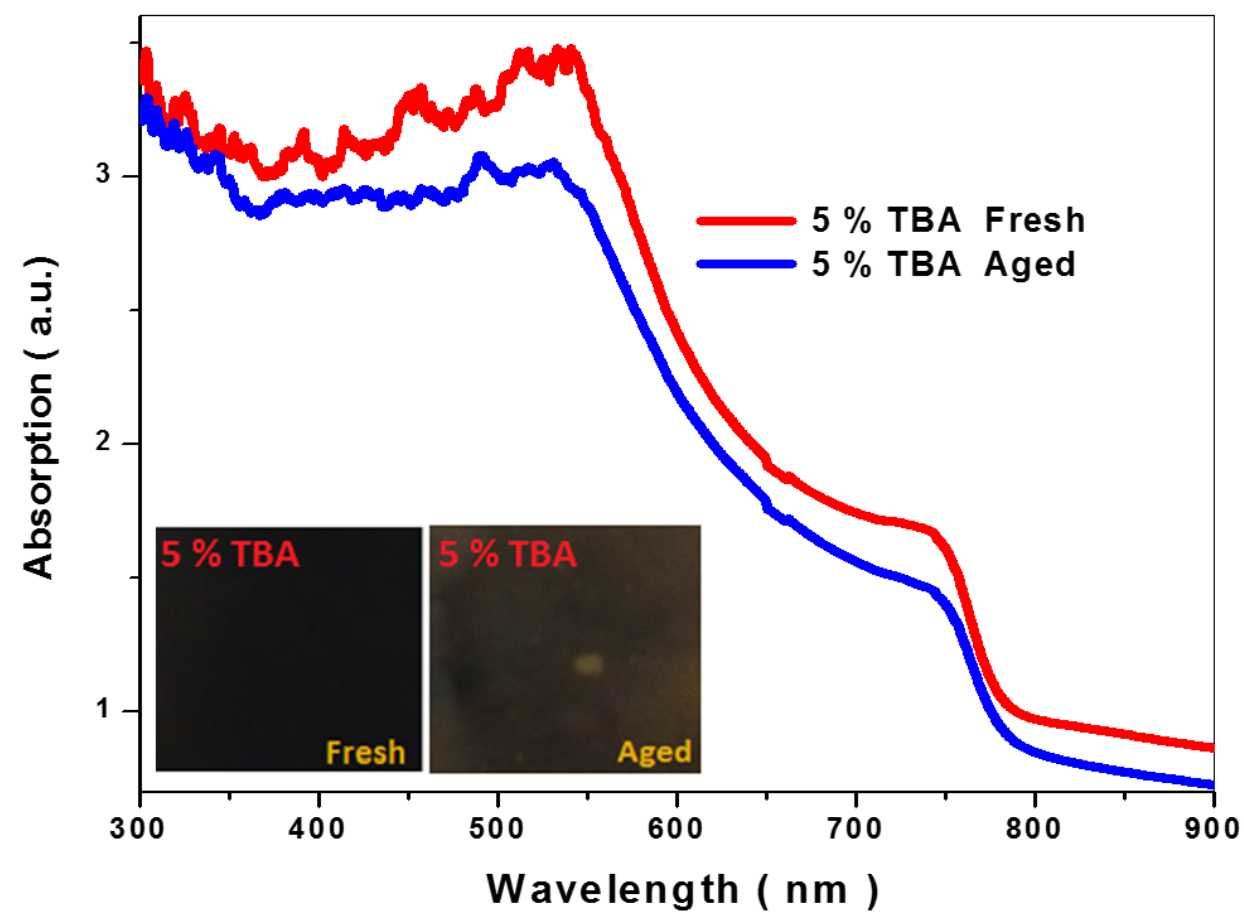

Figure 6.21 Absorbance spectra of doped $\mathrm{MA}_{X} \mathrm{TBA}_{(1-\mathrm{X})} \mathrm{PbI}_{3}$

In conclusion, we have exposed that doping MAPbI3 by small amount of 5\% TBA enhanced the morphology and stability of MAPbI3 perovskite materials appropriate to photovoltaics applications. we have demonstrated that the crystallinity of $\mathrm{MAPbI}_{3}$ films can be improved with the addition of $\mathrm{TBA}$, leading to $\mathrm{MA}_{1-\mathrm{x}} \mathrm{TBA}_{\mathrm{x}} \mathrm{PbI}_{3}$ films with high orientation along the [110] crystallographic direction also showing high coverage with large grain size, good roughness which is valuable for increasing the performance of perovskite solar cells. We have also showed that TBA cation improve the PL emission by decreasing the density of trap states. We have examined the stability of the TBA doped and undoped $\mathrm{MAPbI}_{3}$ films stored at dark under $60 \%$ relative humidity for 15 days and suggest that the incorporation of a small amount of TBA can enhance the stability of perovskite structure of $\mathrm{MAPbI}_{3}$. These results get an insight about the crystallization of $\mathrm{MAPbI}_{3}$ perovskite materials with investigation in optoelectronic properties for high performance $\mathrm{MAPbI}_{3}$ based thin film photovoltaic devices.

\section{Methylammonium lead triiodide $\mathrm{MAPbI}_{3}$ doping by $\mathrm{Rb}$, Li. Cs Perovskites Thin films.}



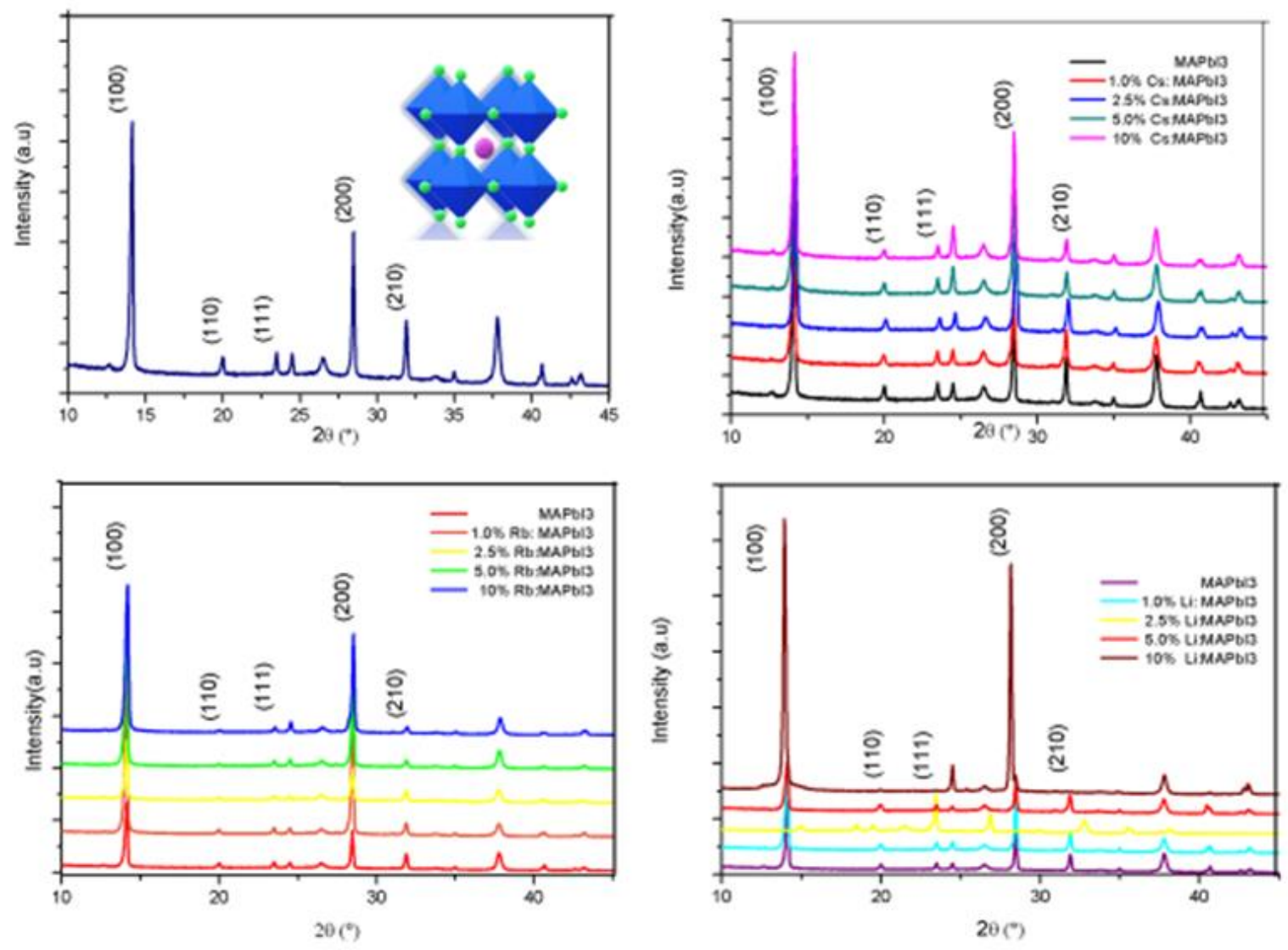

Figure 6.22 a) XRD pattern of spin coated $\mathrm{MAPbI}_{3}$ films b) XRD pattern of spin coated $\mathrm{MAPbI}_{3}$ films with different amounts of $\mathrm{Rb}$ c) XRD pattern of spin coated $\mathrm{MAPbI}_{3}$ films with different amounts of

CS c) XRD pattern of spin coated $\mathrm{MAPbI}_{3}$ films with different amounts of $\mathrm{Li}$

we performed X-ray diffraction (XRD) of $\mathrm{x} \%$ : $\mathrm{MaPbI}_{3}(\mathrm{X}=\mathrm{Rb}, \mathrm{Cs}$, Li where $\mathrm{x}(0,1,2.5,5,10))$ doped films to evaluate the effect of doping by $\mathrm{Rb} / \mathrm{Cs} / \mathrm{Li}$ in $\mathrm{MAPbI}_{3}$ structure. Figure 6.22 illustrates the XRD patterns of $\mathrm{MAPbI}_{3}$ doped with different amounts of $\mathrm{x} \% \mathrm{Rb}$ where $\mathrm{X} \%=(0 \%, 1 \%, 2.5 \%, 5 \%, 10 \%)$. The diffraction peaks positioned at $14^{\circ}, 28^{\circ}, 31^{\circ}, 38^{\circ}, 31^{\circ}, 40.78^{\circ}$ and $43.18^{\circ}$, which agrees to the planes of (110), (200), (211), (202), (220), (310), (224) and (330) respectively where they are a representative of the $\mathrm{MAPbI}_{3}$ structure as it was reported and no binary $\mathrm{PbI}_{2}$ phase was be observed. The maximum XRD peak intensities of (110) and (220) of perovskite films are improved by doping with small amount $(1 \%)$ of $\mathrm{Rb}$ to double intensities with amount $5 \%$, representing well crystallization of the films. This is definitely lead to improving the opto-electronic properties of the $\mathrm{MAPbI}_{3}$ perovskite films. In other hand the XRD pattern of the samples $\mathrm{MAPbI}_{3}$ doped $\mathrm{Cs}$ or $\mathrm{Li}$ show improvement in peaks intensity, the 
maximum XRD peak intensities of perovskite films are increased with the addition of small amount (1\%) of Li or $\mathrm{Cs}$ or $\mathrm{Rb}$.
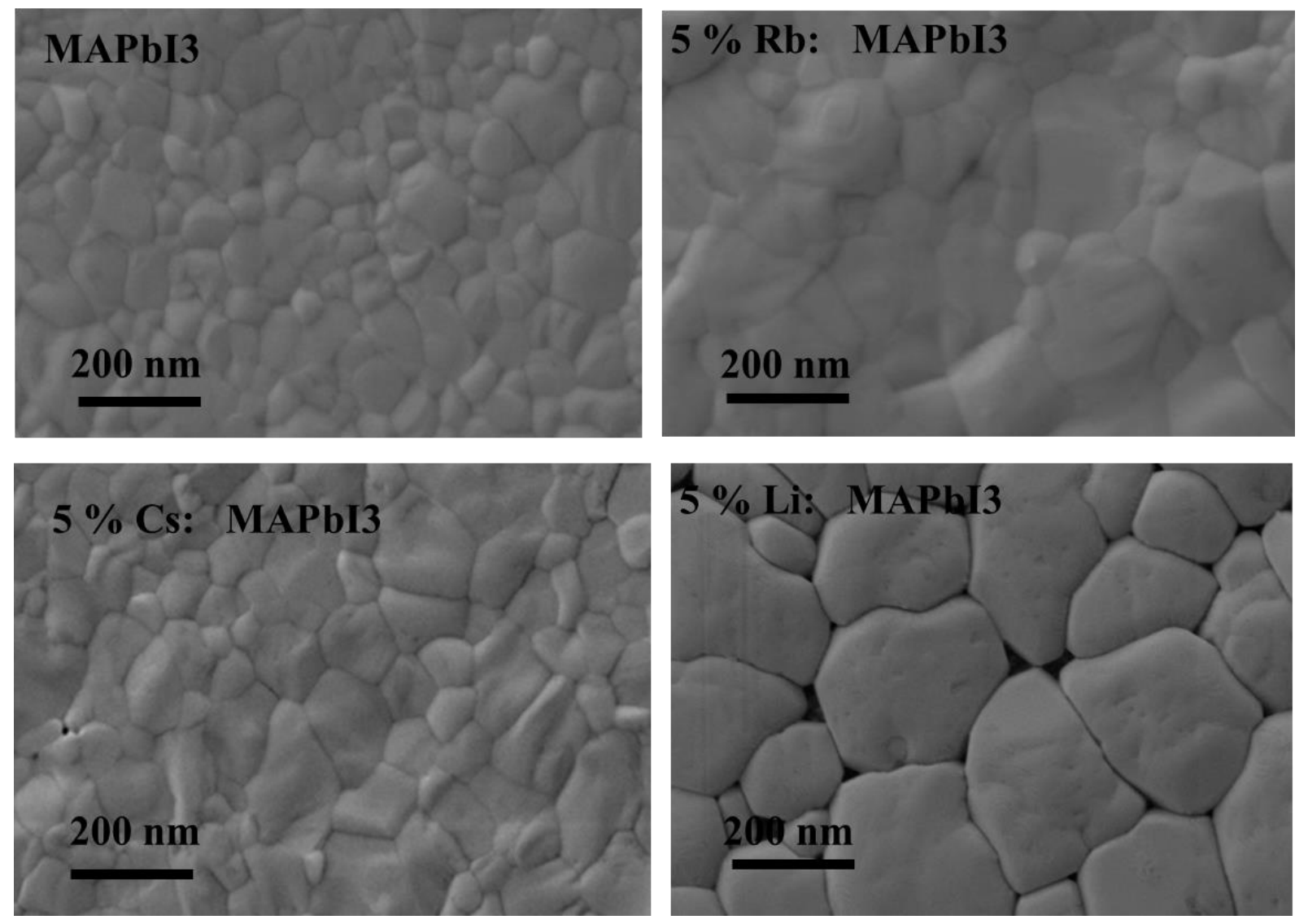

Figure 6.23 $\mathrm{SEM}$ Image of spin coated $\mathrm{MAPbI}_{3}$ film b) XRD pattern of spin coated $\mathrm{MAPbI}_{3}$ films with $5 \% \mathrm{Rb}$ c) XRD pattern of spin coated $\mathrm{MAPbI}_{3}$ films with different amounts of CS c) XRD pattern of spin coated MAPbI3 films with different amounts of $\mathrm{Li}$

SEM images shows free pinholes and holes and growth of perovskite material for the three types of perovskite MA doped by the Rubidium or Lithium or Cesium with different percentage: $1 \%, 2.5 \%, 5 \%, 10 \%$, deposit surfaces are generally very uniform and exhibit excellent surface coverage.

In conclusion, we have showing that doping $\mathrm{MAPbI}_{3}$ by small amount of different materials Rubidium or Lithium or Cesium enhanced the morphology and stability of $\mathrm{MAPbI}_{3}$ perovskite materials appropriate to photovoltaics applications. These results get an insight about the crystallization of $\mathrm{MAPbI}_{3}$ perovskite materials with investigation in optoelectronic properties for high performance $\mathrm{MAPbI}_{3}$ based thin film photovoltaic devices 


\section{References:}

[1] Green, M. A, Emery, K., Hishikawa, Y, Warta, W., \& Dunlop, E. D. (2015). Solar cell efficiency tables (Version 45). Progress in photovoltaics: research and applications, 23(1),1-9.

[2] Jeon, N. J., Na, H., Jung, E. H., Yang, T. Y., Lee, Y. G., Kim, G., ... \& Seo, J. (2018). A fluoreneterminated hole-transporting material for highly efficient and stable perovskite solar cells. Nature Energy, 3(8), 682.

[3] Quarti, C., Mosconi, E., Ball, J. M., D'Innocenzo, V., Tao, C., Pathak, S., ... \& De Angelis, F. (2016). Structural and optical properties of methylammonium lead iodide across the tetragonal to cubic phase transition: implications for perovskite solar cells. Energy \& Environmental Science, 9(1), 155-163.

[4] Im, J. H., Kim, H. S., \& Park, N. G. (2014). Morphology-photovoltaic property correlation in perovskite solar cells: One-step versus two-step deposition of CH3NH3PbI3. Apl Materials, 2(8), 081510.

[5] Carnie, M. J., Charbonneau, C., Davies, M. L., Troughton, J., Watson, T. M., Wojciechowski, K., ... \& Worsley, D. A. (2013). A one-step low temperature processing route for organolead halide perovskite solar cells. Chemical communications, 49(72), 7893-7895.

[6] Bi, D., Moon, S. J., Häggman, L., Boschloo, G., Yang, L., Johansson, E. M., ... \& Hagfeldt, A. (2013). Using a two-step deposition technique to prepare perovskite (CH $3 \mathrm{NH} 3 \mathrm{PbI} 3$ ) for thin film solar cells based on $\mathrm{ZrO} 2$ and TiO 2 mesostructures. Rsc Advances, 3(41), 18762-18766.

[7] Chen, Q., Zhou, H., Hong, Z., Luo, S., Duan, H. S., Wang, H. H., ... \& Yang, Y. (2013). Planar heterojunction perovskite solar cells via vapor-assisted solution process. Journal of the American Chemical Society, 136(2), 622-625.

[8] Leyden, M. R., Ono, L. K., Raga, S. R., Kato, Y., Wang, S., \& Qi, Y. (2014). High performance perovskite solar cells by hybrid chemical vapor deposition. Journal of Materials Chemistry A, 2(44), 18742-18745.

[9] Kong, W., Ye, Z., Qi, Z., Zhang, B., Wang, M., Rahimi-Iman, A., \& Wu, H. (2015). Characterization of an abnormal photoluminescence behavior upon crystal-phase transition of perovskite CH 3 NH 3 PbI 3. Physical Chemistry Chemical Physics, 17(25), 16405-16411.

[10] Guo, X., McCleese, C., Kolodziej, C., Samia, A. C., Zhao, Y., \& Burda, C. (2016). Identification and characterization of the intermediate phase in hybrid organic-inorganic MAPbI 3 perovskite. Dalton Transactions, 45(9), 3806-3813 
[11] Xiao, Z., Dong, Q., Bi, C., Shao, Y., Yuan, Y., \& Huang, J. (2014). Solvent annealing of perovskite-induced crystal growth for photovoltaic-device efficiency enhancement. Advanced Materials, 26(37), 6503-6509.

[12] Luo, S., \& Daoud, W. A. (2016). Crystal structure formation of CH3NH3PbI3-xClx perovskite. Materials, 9(3), 123.

[13] Park, N. G. (2016). Crystal growth engineering for high efficiency perovskite solar cells. CrystEngComm, 18(32), 5977-5985.

[14] Zheng, X., Chen, B., Wu, C., \& Priya, S. (2015). Room temperature fabrication of $\mathrm{CH} 3 \mathrm{NH} 3 \mathrm{PbBr} 3$ by anti-solvent assisted crystallization approach for perovskite solar cells with fast response and small J-V hysteresis. Nano Energy, 17, 269-278.

[15] Jeangros, Q., Duchamp, M., Werner, J., Kruth, M., Dunin-Borkowski, R. E., Niesen, B. \& Hessler-Wyser, A. (2016). In situ TEM analysis of organic-inorganic metal-halide perovskite solar cells under electrical bias. Nano letters, 16(11), 7013-7018.

[16] Liu, D., Yang, J., \& Kelly, T. L. (2014). Compact layer free perovskite solar cells with $13.5 \%$ efficiency. Journal of the American Chemical Society, 136(49), 17116-17122.

[17] Zhang, M., Yu, H., Lyu, M., Wang, Q., Yun, J. H., \& Wang, L. (2014). Composition-dependent photoluminescence intensity and prolonged recombination lifetime of perovskite $\mathrm{CH} 3 \mathrm{NH} 3 \mathrm{PbBr}$ 3- x Cl x films. Chemical Communications, 50(79), 11727-11730.

[18] Choi, J. J., Yang, X., Norman, Z. M., Billinge, S. J., \& Owen, J. S. (2013). Structure of methylammonium lead iodide within mesoporous titanium dioxide: active material in highperformance perovskite solar cells. Nano letters, 14(1), 127-133.

[19] Halder, A., Chulliyil, R., Subbiah, A. S., Khan, T., Chattoraj, S., Chowdhury, A., \& Sarkar, S. K. (2015). Pseudohalide (SCN-)-doped MAPbI3 perovskites: A few surprises. The journal of physical chemistry letters, 6(17), 3483-3489.

[20] Xie, Z., Sun, S., Yan, Y., Zhang, L., Hou, R., Tian, F., \& Qin, G. G. (2017). Refractive index and extinction coefficient of $\mathrm{NH} 2 \mathrm{CH}=\mathrm{NH} 2 \mathrm{PbI} 3$ perovskite photovoltaic material. Journal of Physics: Condensed Matter, 29(24), 245702.

[21] Homes, C. C., Vogt, T., Shapiro, S. M., Wakimoto, S., \& Ramirez, A. P. (2001). Optical response of high-dielectric-constant perovskite-related oxide. Science, 293(5530), 673-676.

[22] Abdelmageed, G., Jewell, L., Hellier, K., Seymour, L., Luo, B., Bridges, F., ... \& Carter, S. (2016). Mechanisms for light induced degradation in MAPbI3 perovskite thin films and solar cells. Applied Physics Letters, 109(23), 233905. 
[23] Li, J., Dong, Q., Li, N., \& Wang, L. (2017). Direct Evidence of Ion Diffusion for the SilverElectrode-Induced Thermal Degradation of Inverted Perovskite Solar Cells. Advanced Energy Materials, 7(14), 1602922.

[24] Aristidou, N., Sanchez-Molina, I., Chotchuangchutchaval, T., Brown, M., Martinez, L., Rath, T., \& Haque, S. A. (2015). The role of oxygen in the degradation of methylammonium lead trihalide perovskite photoactive layers. Angewandte Chemie International Edition, 54(28), 8208-8212.

[25] Weidman, M. C., Seitz, M., \& Tisdale, W. A. (2019). U.S. Patent No. 10,273,405. Washington, DC: U.S. Patent and Trademark Office.

[26] Smith, M. D., Connor, B. A., \& Karunadasa, H. I. (2019). Tuning the luminescence of layered halide perovskites. Chemical reviews, 119(5), 3104-3139.

[27] Quan, L. N., Rand, B. P., Friend, R. H., Mhaisalkar, S. G., Lee, T. W., \& Sargent, E. H. (2019). Perovskites for Next-Generation Optical Sources. Chemical reviews, 119(12), 7444-7477.

[28] Fakharuddin, A., Shabbir, U., Qiu, W., Iqbal, T., Sultan, M., Heremans, P., \& Schmidt-Mende, L. (2019). Inorganic and Layered Perovskites for Optoelectronic Devices. Advanced Materials, 1807095 .

[29] Wang, Y., Fang, W. H., Long, R., \& Prezhdo, O. V. (2019). Symmetry Breaking at MAPbI3 Perovskite Grain Boundaries Suppresses Charge Recombination: Time-Domain ab Initio Analysis. The journal of physical chemistry letters, 10(7), 1617-1623.

[30] Im, J. H., Lee, C. R., Lee, J. W., Park, S. W., \& Park, N. G. (2011). 6.5\% efficient perovskite quantum-dot-sensitized solar cell. Nanoscale, 3(10), 4088-4093.

[31] De Roo, J., Ibáñez, M., Geiregat, P., Nedelcu, G., Walravens, W., Maes, J., ... \& Hens, Z. (2016). Highly dynamic ligand binding and light absorption coefficient of cesium lead bromide perovskite nanocrystals. ACS nano, 10(2), 2071-2081.

[32] Park, N. G. (2015). Perovskite solar cells: an emerging photovoltaic technology. Materials today, 18(2), 65-72.

[33] Xiao, Z., Bi, C., Shao, Y., Dong, Q., Wang, Q., Yuan, Y., ... \& Huang, J. (2014). Efficient, high yield perovskite photovoltaic devices grown by interdiffusion of solution-processed precursor stacking layers. Energy \& Environmental Science, 7(8), 2619-2623. 
[34] Yantara, N., Sabba, D., Yanan, F., Kadro, J. M., Moehl, T., Boix, P. P., ... \& Grätzel, C. (2015). Loading of mesoporous titania films by $\mathrm{CH} 3 \mathrm{NH} 3 \mathrm{PbI} 3$ perovskite, single step vs. sequential deposition. Chemical Communications, 51(22), 4603-4606.

[35] Ko, H. S., Lee, J. W., \& Park, N. G. (2015). 15.76\% efficiency perovskite solar cells prepared under high relative humidity: importance of PbI 2 morphology in two-step deposition of CH 3 NH 3 PbI 3. Journal of Materials Chemistry A, 3(16), 8808-8815.

[36] Chen, Q., Zhou, H., Hong, Z., Luo, S., Duan, H. S., Wang, H. H., ... \& Yang, Y. (2013). Planar heterojunction perovskite solar cells via vapor-assisted solution process. Journal of the American Chemical Society, 136(2), 622-625.

[37] Patel, J. B., Wong-Leung, J., Van Reenen, S., Sakai, N., Wang, J. T. W., Parrott, E. S., ... \& Johnston, M. B. (2017). Influence of Interface Morphology on Hysteresis in Vapor-Deposited Perovskite Solar Cells. Advanced Electronic Materials, 3(2), 1600470.

[38] Niu, G., Yu, H., Li, J., Wang, D., \& Wang, L. (2016). Controlled orientation of perovskite films through mixed cations toward high performance perovskite solar cells. Nano Energy, 27, 87-94.

[39] Li, J., Jiu, T., Duan, C., Wang, Y., Zhang, H., Jian, H., \& Li, Y. (2018). Improved electron transport in MAPbI3 perovskite solar cells based on dual doping graphdiyne. Nano Energy, 46, 331337.

[40] Gong, J., Yang, M., Rebollar, D., Rucinski, J., Liveris, Z., Zhu, K., \& Xu, T. (2018). Divalent anionic doping in perovskite solar cells for enhanced chemical stability. Advanced Materials, 30(34), 1800973.

[41] Ahmad, Z., Shikoh, A. S., Paek, S., Nazeeruddin, M. K., Al-Muhtaseb, S. A., Touati, F., ... \& Al-Thani, N. J. (2019). Degradation analysis in mixed (MAPbI 3 and MAPbBr 3) perovskite solar cells under thermal stress. Journal of Materials Science: Materials in Electronics, 30(2), 1354-1359. [42] Abdelmageed, G., Jewell, L., Hellier, K., Seymour, L., Luo, B., Bridges, F., ... \& Carter, S. (2016). Mechanisms for light induced degradation in MAPbI3 perovskite thin films and solar cells. Applied Physics Letters, 109(23), 233905. 
[43] Ono, L. K., Raga, S. R., Remeika, M., Winchester, A. J., Gabe, A., \& Qi, Y. (2015). Pinholefree hole transport layers significantly improve the stability of MAPbI 3-based perovskite solar cells under operating conditions. Journal of Materials Chemistry A, 3(30), 15451-15456.

[44] Yu, W., Yu, S., Zhang, J., Liang, W., Wang, X., Guo, X., \& Li, C. (2018). Two-in-one additiveengineering strategy for improved air stability of planar perovskite solar cells. Nano Energy, 45, 229235.

[45] Fateev, S. A., Petrov, A. A., Khrustalev, V. N., Dorovatovskii, P. V., Zubavichus, Y. V., Goodilin, E. A., \& Tarasov, A. B. (2018). Solution processing of methylammonium lead iodide perovskite from $\gamma$-butyrolactone: crystallization mediated by solvation equilibrium. Chemistry of Materials, 30(15), 5237-5244.

[46] Chen, L. C., Lee, K. L., Wu, W. T., Hsu, C. F., Tseng, Z. L., Sun, X. H., \& Kao, Y. T. (2018). Effect of different $\mathrm{CH} 3 \mathrm{NH} 3 \mathrm{PbI} 3$ morphologies on photovoltaic properties of perovskite solar cells. Nanoscale research letters, 13(1), 140.

[47] Banerjee, D., \& Chattopadhyay, K. K. (2018). Hybrid Inorganic Organic Perovskites: A LowCost-Efficient Optoelectronic Material. In Perovskite Photovoltaics (pp. 123-162). Academic Press.

[48] Liu, C., Cheng, Y. B., \& Ge, Z. (2020). Understanding of perovskite crystal growth and film formation in scalable deposition processes. Chemical Society Reviews, 49(6), 1653-1687.

[49] Guo, P., Ye, Q., Yang, X., Zhang, J., Xu, F., Shchukin, D., ... \& Wang, H. (2019). Surface \& grain boundary co-passivation by fluorocarbon based bifunctional molecules for perovskite solar cells with efficiency over $21 \%$. Journal of materials chemistry A, 7(6), 2497-2506.

[50] Giesbrecht, N., Schlipf, J., Grill, I., Rieder, P., Dyakonov, V., Bein, T., ... \& Docampo, P. (2018). Single-crystal-like optoelectronic-properties of MAPbI 3 perovskite polycrystalline thin films. Journal of Materials Chemistry A, 6(11), 4822-4828.

[51] Jones, T. W., Osherov, A., Alsari, M., Sponseller, M., Duck, B. C., Jung, Y. K., ... \& Li, Y. (2019). Lattice strain causes non-radiative losses in halide perovskites. Energy \& Environmental Science, 12(2), 596-606. 
[52] Tombe, S., Adam, G., Heilbrunner, H., Yumusak, C., Apaydin, D. H., Hailegnaw, B., ... \& Sariciftci, N. S. (2018). The influence of perovskite precursor composition on the morphology and photovoltaic performance of mixed halide MAPbI3-xClx solar cells. Solar Energy, 163, 215-223.

[53] Sun, C., Guo, Y., Fang, B., Guan, L., Duan, H., Chen, Y., ... \& Liu, H. (2017). Facile preparation of high-quality perovskites for efficient solar cells via a fast conversion of wet PbI 2 precursor films. RSC advances, 7(36), 22492-22500.

[54] Ngo, T. H., Gil, B., Shubina, T. V., Damilano, B., Vezian, S., Valvin, P., \& Massies, J. (2018). Enhanced excitonic emission efficiency in porous GaN. Scientific reports, 8(1), 1-9.

[55] Brennan, M. C., Zinna, J., \& Kuno, M. (2017). Existence of a size-dependent Stokes shift in $\mathrm{CsPbBr3}$ perovskite nanocrystals. ACS Energy Letters, 2(7), 1487-1488.

[56] Kanemitsu, Y. (2017). Luminescence spectroscopy of lead-halide perovskites: materials properties and application as photovoltaic devices. Journal of Materials Chemistry C, 5(14), 34273437.

[57] Huang, J., Tan, S., Lund, P. D., \& Zhou, H. (2017). Impact of H 2 O on organic-inorganic hybrid perovskite solar cells. Energy \& Environmental Science, 10(11), 2284-2311.

[58] Kundu, S., \& Kelly, T. L. In situ studies of the degradation mechanisms of perovskite solar cells. EcoMat. 


\section{Chapter VII}

\section{Synthesis and characterization of}

\section{Formamidinium lead triiodide $\mathrm{FAPbI}_{3}$ perovskite.}

1. Film Preparation of $\mathrm{FAPbI}_{3}$ doped Guanidinium perovskite films ............................ 141

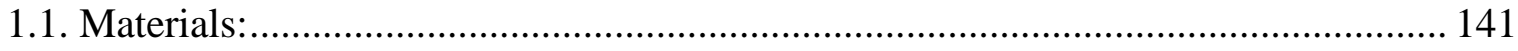

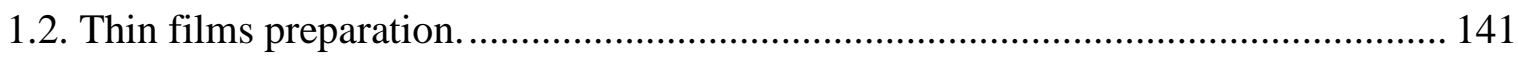

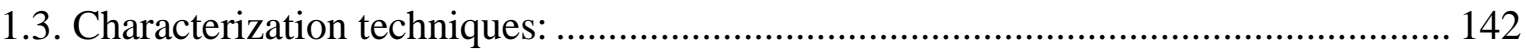

1.4. Structural and morphological analysis of $\mathrm{FAPbI}_{3}$ doped GA Perovskite Thin Films 142

1.5. Optical analysis of $\mathrm{FAPbI}_{3}$ doped GA Perovskite Thin Films................................ 146

2. Degradation mechanism of $\mathrm{FAPbI}_{3}$ and $\mathrm{GA}$ doped $\mathrm{FAPbI}_{3}$ Perovskite Thin Films......... 148 


\section{Introduction:}

Hybrid perovskites solar cells have experienced a significant improvement in efficiency during these last few years, the power conversion efficiency (PCE) has amplified from 3.8\% in 2009 to over $25 \%$ in 2019 [1] and still a window for researchers to improve the (PCE) in the future specially the Perovskites have flexibility for chemical substitution [2].

Hybrid perovskites solar cells have experienced a significant improvement in efficiency during these last few years, the power conversion efficiency (PCE) has amplified from $3.8 \%$ in 2009 to over $25 \%$ in 2019 [1] and still a window for researchers to improve the (PCE) in the future specially the Perovskites have flexibility for chemical substitution [2] The general chemical formula of a perovskite structure is $\mathrm{ABX} 3$ where $\mathrm{A}$ is big cation $=(\mathrm{MA}, \mathrm{FA}, \mathrm{Cs}), \mathrm{B}$ is a small cation $(\mathrm{Pb}, \mathrm{Sn} .$. and three anions $\mathrm{X}=(\mathrm{Cl}, \mathrm{I}, \mathrm{Br})$. Many techniques have been used For the fabrication of perovskite thin films with high quality, One of the promising methods is one-step solution deposition by spin counting is used because of the simple and low manufacturing costs [3], two-step solution deposition by spin counting that simple to control and generally used for the elaboration of perovskites thin film [4] two-step vapor-assisted deposition [5], and vapor deposition normally used for production highquality thin layers with uniform thickness and composition [6] Quantum Dot [7] blade coating [8].

Formamidinium lead iodide (FAPbI3) is one the most attractive perovskite materials due to the fact of band gap about $1.47 \mathrm{eV}$, suitable for photovoltaic applications [9] higher photo and thermal stability compared to the $\mathrm{MAPbI}_{3}[10]$. Nevertheless, the desired black $\alpha-\mathrm{FAPbI} 3$ perovskite phase turn to the yellow phase $\delta-\mathrm{FAPbI}_{3}$ at humid conditions. To date, the most reported studies on the FAPbI3 material focuses on the stabilization of black $\alpha-\mathrm{FAPbI}_{3}$ at moderately low temperature [11]. To date, the most work on $\mathrm{FAPbI}_{3}$ perovskites is focused on the stabilization of black $\alpha-\mathrm{FAPbI}_{3}$ at moderately low temperature.

Although numerous studies have proposed different solutions to improve the $\mathrm{FAPbI}_{3}$ phase stability, the $\mathrm{FA}_{0.85} \mathrm{Cs}_{0.15} \mathrm{PbI}_{3}$ thin film has been reported to be a very weakly degradation and reactivity to the white light by storing at ambient condition for 45 days [12] The relative stability of the desired $\alpha-\mathrm{FAPbI}_{3}$, photoactive perovskite $\alpha$-phase described as the black phase, non-perovskite $\delta$ phase corresponds to yellow phase was investigated in terms of dopant cation $\mathrm{Cs}+$ and $\mathrm{Rb}+$ and revealed to be more effective in the stabilization of the desired- $\alpha$ phase [13] specially that Cs + cation has exposed by ionic radius: $1.67 \AA$ excellent potential for stabilization of $\mathrm{FAPbI}_{3}$ perovskite. It was been described that that substitution of $\mathrm{FA}^{+}$by $\mathrm{Cs}^{+}$makes the contraction of the cubo-octahedral volume and improves FA-I interaction which improves the stabilization of the $\mathrm{FAPbI}_{3}$ perovskite 
structure. It was been presented that incorporation of $10 \%$ of $\mathrm{Cs}^{+}$improves the humidity-tolerance of the Perovskite Solar Cells (PSCs) [14]. An analogous study was informed where they made calculations to explain such amazing stabilization behavior with cesium. However, its large band gad limits their application as absorbing layer in perovskite solar cell devices [15].

Here we demonstrate that the introduction of small amounts of $\left[\left(\mathrm{NH}_{2}\right)_{3} \mathrm{C}\right]^{+}$(guanidinium $(\mathrm{GA})$, $278 \mathrm{pm}$ ) cation by substituted the $\left[\mathrm{CH}\left(\mathrm{NH}_{2}\right)_{2}\right]^{+}($Formamidinium, $253 \mathrm{pm})$ cation, provides a new slant to improve the structural, morphological and optical properties of $\mathrm{FAPbI}_{3}$ also the degradation became under control. and the stability of the perovskite phase. In particular, we explored addition of GA cation into FAPbI3 and observed its effect on stabilization of the black phase. As found here, the addition of certain amount of GA stabilizes the black phase at room temperature and under ambient conditions Furthermore, it was noticed that the stability remained excellent in a humid environment (relative humidity of $\sim 60 \%$ ).

\section{Film Preparation of $\mathrm{FAPbI}_{3}$ doped Guanidinium perovskite films}

\subsection{Materials:}

All the chemicals were purchased from Sigma Aldrich without any further purification as received. Where Formamidinium iodide (FAI), Lead iodide $\left(\mathrm{PbI}_{2}, 99 \%\right)$, Guanidinium iodide (GAI, 99\%) as starting materials. Dimethylformamide (DMF 99.8\%), Dimethyl sulfoxide (DMSO 99.9\%) as solvents and chlorobenzene $(99.8 \%)$ were used as anti-solvent.

\subsection{Thin films preparation.}

The perovskite thin films were elaborated on Florin Tin Oxide (FTO) substrate in size of $2 \times$ $2 \mathrm{~cm}$. The substrates were carefully cleaned with detergent, acetone and isopropanol (IPA) each for 15 min holding time respectively, in an ultrasonic bath. The cleaned FTO substrates were dried in air and finally kept in UV ozone cleaner for $15 \mathrm{~min}$. Thin film solutions were prepared from 1M FAI, 1.05M PbI 2 and 0.2M GAI were dissolved in DMF and DMSO solution for one hour. Then subsequently the prepared solutions were mixed at room temperature and kept it on a hot plate at 80 ${ }^{\circ} \mathrm{C}$ for two hours in the glovebox. Finally, the mixed solution was filtered with a $0.40 \mu \mathrm{m}$ (PTFE) filter, then $50 \mu 1$ of the solution was spin-coated at $2000 \mathrm{rpm}$ for $10 \mathrm{~s}$ on cleaned FTO substrate, $1 \mathrm{~mL}$ chlorobenzene was immediately dropped onto the wet $\mathrm{FA}_{1-\mathrm{x}} \mathrm{GA}_{\mathrm{x}} \mathrm{PbI}_{3}$ films at $5000 \mathrm{rpm}$ for $50 \mathrm{~s}$. Subsequently, the as-prepared thin films were thermally annealed at $220{ }^{\circ} \mathrm{C}$ for $10 \mathrm{~min}$. 


\subsection{Characterization techniques:}

Thin films $\mathrm{FAPbI}_{3}$ and doped $\mathrm{GA}$ at different $\mathrm{X} \%(0 \%, 2.5 \%, 5 \%, 10 \%$ and 20\%) were characterized by X-ray diffraction (XRD) RIGAKU Ultima IV with $\mathrm{Cu}$ k $\alpha$ radiation $(\lambda=1.5418 \AA$ ). Morphology images were taken by scanning electron microscope (SEM) Quanta 200-FEI at applied voltage $1.5 \mathrm{kV}$. The topography of the samples was analyzed by Atomic Force Microscopy (AFM) Bruker Multimode 8 AFM Nanoscope V controller. Transmission electron microscopy (TEM) model JEO-JEM-1010 TEM microscope was used at applied potential $2.5 \mathrm{kV}$. Optical properties were performed using Ocean Optics HR4000 spectrophotometer with a Si-CCD. Photoluminescence (PL) emission source was a He-Cd laser at $405 \mathrm{~nm}$ and the PL data were collected by a Hamamatsu SiCCD detector.

\subsection{Structural and morphological analysis of $\mathrm{FAPbI}_{3}$ doped GA Perovskite Thin Films}

The structural properties of $\mathrm{FA}_{1-\mathrm{x}} \mathrm{GA}_{\mathrm{x}} \mathrm{PbI}_{3}$ was systematically identified with different guanidinium content $(0 \%, 2.5 \%, 5 \%, 10 \%$ and $20 \%)$. The $\mathrm{FAPbI}_{3}$ films $\mathrm{XRD}$ analysis shows a typical perovskite peaks of $\alpha-\mathrm{FaPbI}_{3} ;(110)$, (220) located at $14.00^{\circ}$ and $28.13^{\circ}$ respectively, on the other hand the undesired $\delta-\mathrm{FAPbI}_{3}(010)$ peak located at $11.8^{\circ}$ displayed in Figure 7.1 (a) $[16,17]$. The addition of $2.5 \%$ GA decreases the (010) peak intensity, indicating the coexistence of the two perovskite phases. Furthermore, the incorporation of GA at $10 \%$ the $\alpha-\mathrm{FAPbI}_{3}$ phase becomes predominant and the (010) almost disappears Figure 7.2 (a) 

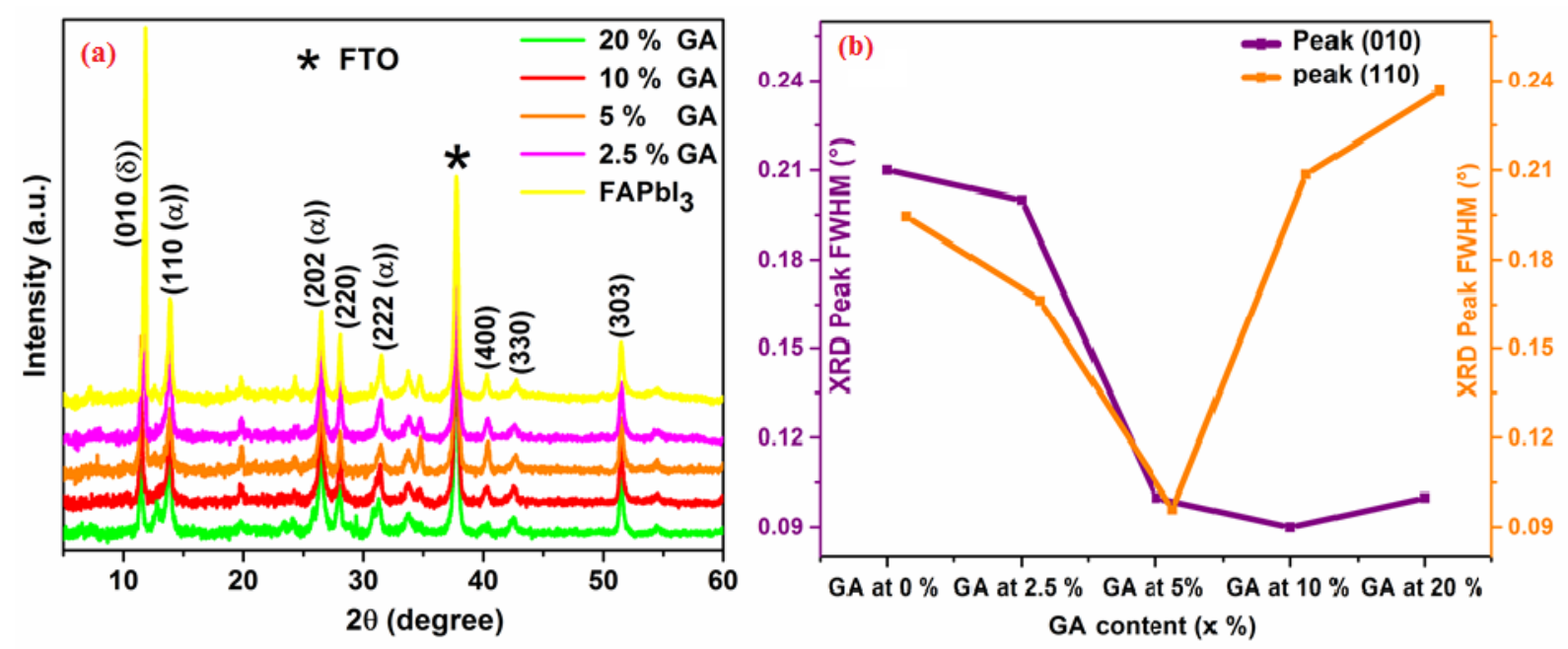

(c)

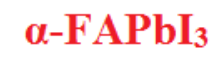

\section{$\delta-\mathrm{FAPbI}_{3}$}
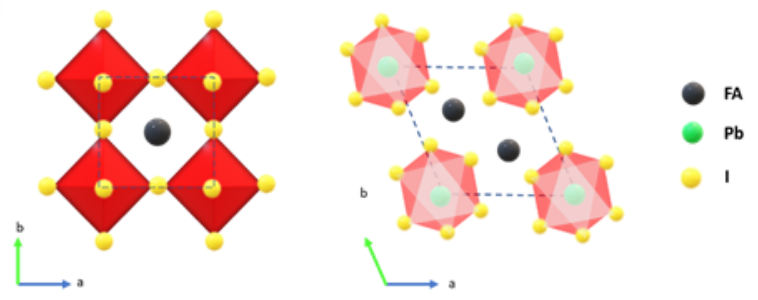

Figure 7.1. (a) $\mathrm{XRD}$ patterns of perovskite films $\mathrm{FA}_{1-\mathrm{x}} \mathrm{GA}_{x} \mathrm{PbI}_{3}$ (b) $\mathrm{FWHM}$ of $\alpha-\mathrm{FAPbI}_{3}(110)$ and $\delta-\mathrm{FAPbI}_{3}(010)$ peaks (c) Crystal structure of $\alpha$ and $\delta \mathrm{FAPbI}_{3}$ phases.

Figure 7.1 (b) illustrates the zoomed XRD in the range of $10^{\circ}$ to $17^{\circ}$ which is an agreement that the GA content indicates an improvement in the $\alpha-\mathrm{FAPbI}_{3}$ peaks intensity and a decrease of the $\delta$-FAPbI 3 peak was observed. These results are well match with the previously reported pure $\mathrm{FAPbI}_{3}$ crystalline phase [18-22]. For the $20 \% \mathrm{GA}$ sample, the diffraction peak (001) in $11.4^{\circ}$ could be attributed to a compound corresponds of the $\mathrm{FA}_{3} \mathrm{PbI}_{5}$. we noted that the excess of FAI is not detected in all the diffraction diagrams XRD, which is likely. 

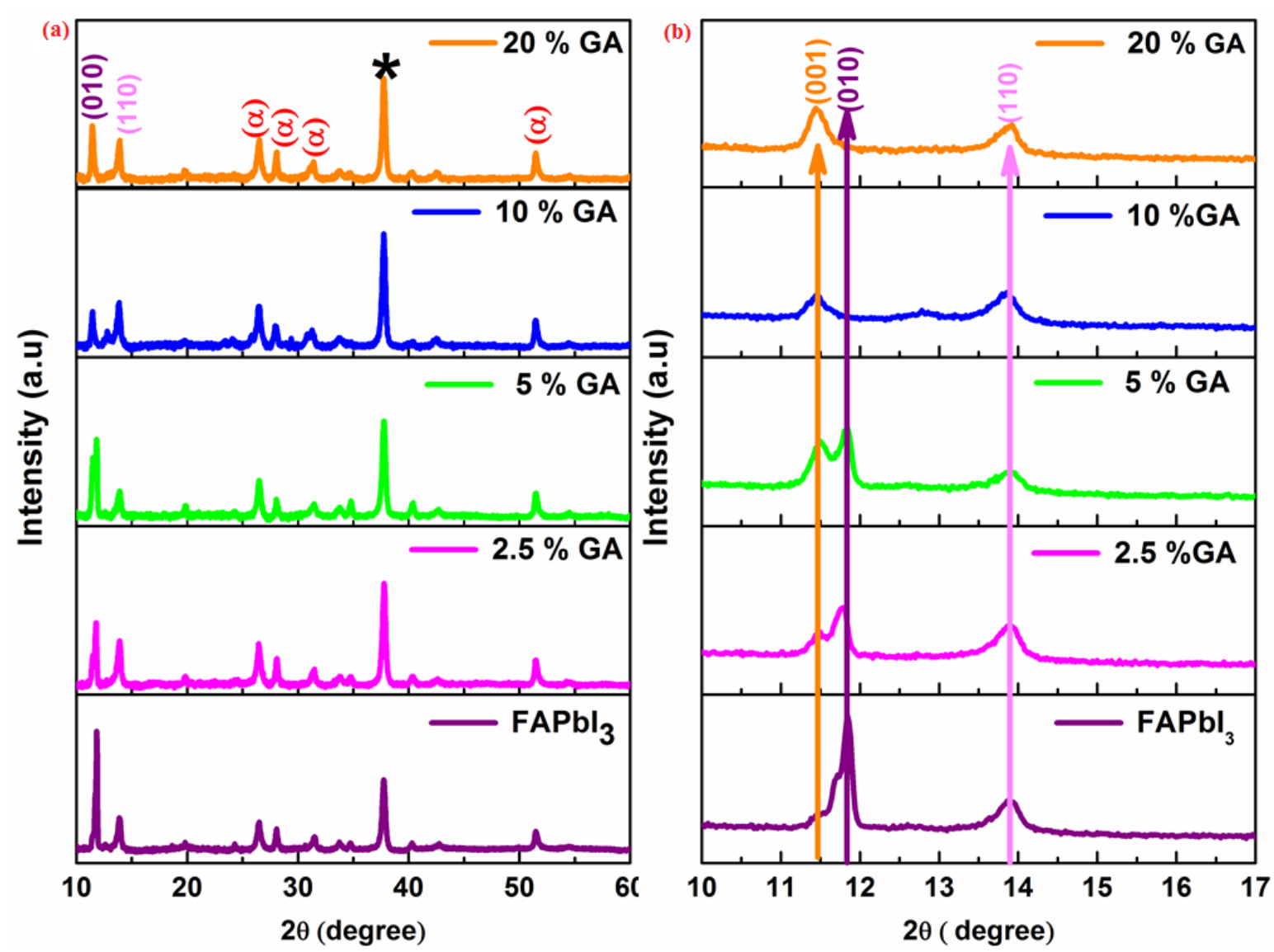

Figure 7.2. (a) $\mathrm{XRD}$ perovskite films $\mathrm{FA}_{1-\mathrm{x}} \mathrm{GA}_{\mathrm{x}} \mathrm{PbI}_{3}$ and (b) zoomed $\mathrm{XRD}$ patterns from 10 to 17 degree.

As shown in Figure 7.1 (b) the FWHM of peaks (110) and (010) decreases which indicates the good crystallinity of this sample. The $\mathrm{FAPbI}_{3}$ grain size was found to be around $239 \mathrm{~nm}$ after $10 \%$ GA doping. Furthermore, the incorporation of GA (x \% $=0,10,20)$ crystal structure, lattice parameters and Grain size details were extracted from Pawley refinement calculation. which can be referred of introducing GA (278 pm) that has a more volume size than FA (253 pm) further the incorporation of GA augmented the lattice parameters (Table 7.1). As previously detailed Overall, we are able to obtain a $\mathrm{FAPbI}_{3}$ thin films through a controllable $\alpha / \delta$ phases by good adjusting of the GA amount $[23,24,25]$.

Table 7.1. Lattice parameters of $\mathrm{FA}_{1-\mathrm{x}} \mathrm{GA}_{x} \mathrm{PbI}_{3}$ via the Pawley method.

\begin{tabular}{|l|l|l|l|l|l|l|}
\hline Sample & $\mathbf{a}=\mathbf{b}(\AA)$ & $\mathbf{c}(\AA)$ & $\begin{array}{l}\text { Grain } \\
(\mathbf{n m})\end{array}$ & Size & $\begin{array}{l}\text { Dislocation density } \\
\left(\mathbf{n m}^{-1}\right)\end{array}$ & $\begin{array}{l}\text { Lattice } \\
\text { strain }(\varepsilon)\end{array}$ \\
\hline FAPbI 3 & 8.90 & 11.09 & 208 & & $4.8010^{-03}$ & 0.180 \\
\hline $10 \%$ GA & 8.91 & 11.11 & 239 & $4.181^{-03}$ & 0.160 \\
\hline $20 \%$ GA & 8.99 & 11.13 & 213 & $4.691^{-03}$ & 0.180 \\
\hline
\end{tabular}


The surface morphology SEM images of $\mathrm{FAPbI}_{3}$ thin films doped with different amount of GA display in figure 7.3 (a-f). All thin films exhibit a comparatively smooth surface coverage with clear boundaries and without pinholes. Upon partial substitution $2.5 \%$ GA the film reveals increase in grain size which is further examined by the incorporation of $10 \%$ GA led compact and pinholes free surface. The excess of GA (x \% > $10 \%$ ) effect was not clearly observed in the morphology and well matched with the $\mathrm{XRD}$ results $\mathrm{FA}_{3} \mathrm{PbI}_{5}[27,28]$.

Figure 7.3 (g) illustrates a high resolution TEM image that exposes the micro $(\mu)$ monodispersed feature of the $\mathrm{FAPbI}_{3}$ doped by $10 \% \mathrm{GA}$. Thin Film lattice fringes associated with a d-spacing $0.61 \mathrm{~nm}$ confirmed by high resolution images. Figure 7.3 (h-i) exhibits polycrystalline nature diffraction rings dispersion with $10 \%$ GA [29].
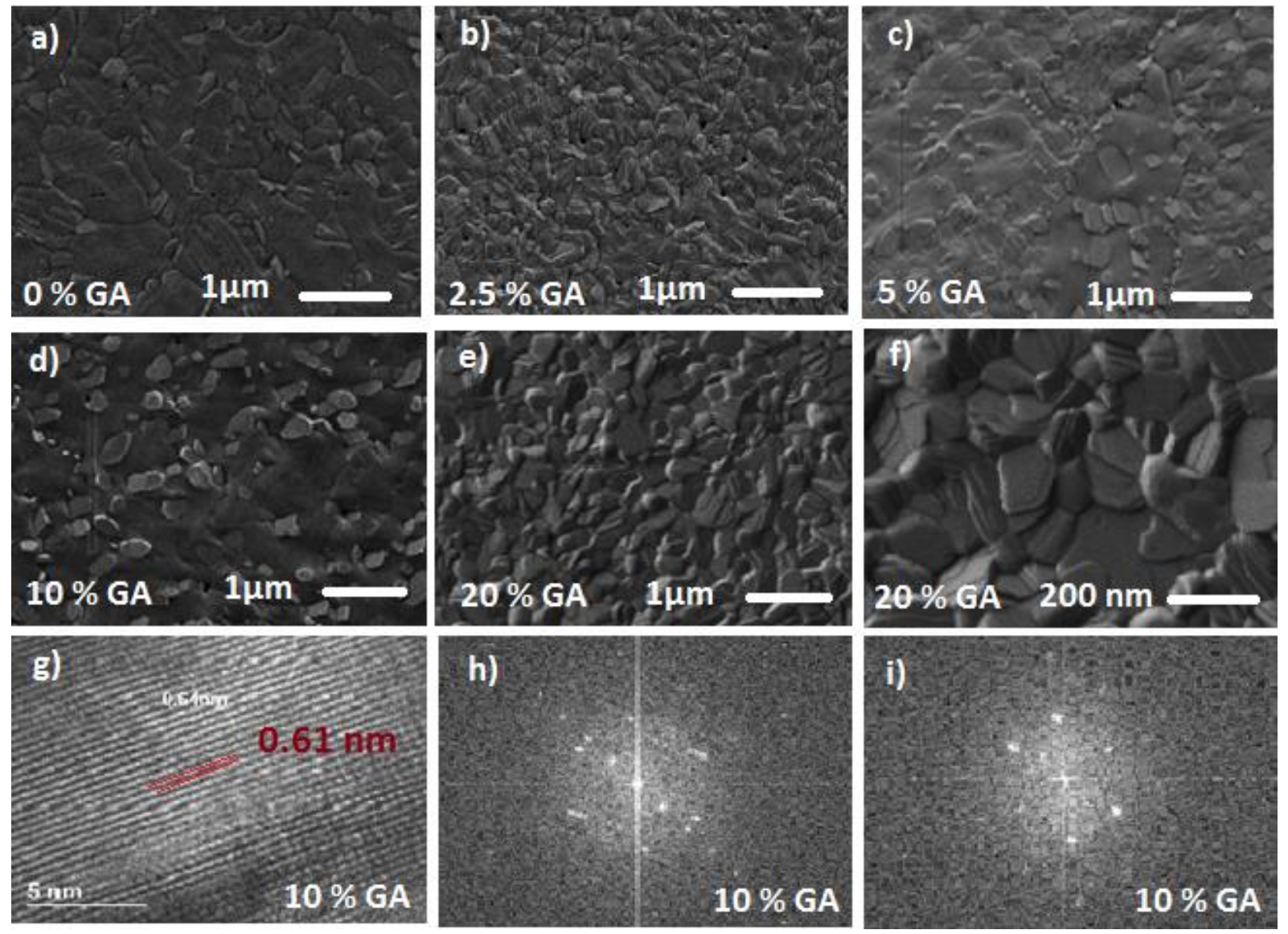

Figure 7.3. SEM Image of perovskite films $\mathrm{FA}_{1-\mathrm{x}} \mathrm{GA}_{\mathrm{x}} \mathrm{PbI}_{3}$ a) $0 \% \mathrm{GA}$ b) $2.5 \% \mathrm{GA}$ c) $5 \%$ GA d) $10 \%$ GA e) $20 \%$ GA f) $20 \%$ GA with scale $200 \mathrm{~nm}$ (g-i) TEM Images of perovskite films of $10 \%$ GA. 
Figure 7.4 shows the AFM analysis of the surface topography of $\mathrm{FA}_{1-\mathrm{x}} \mathrm{GA}_{\mathrm{x}} \mathrm{PbI}_{3}$ samples. The results reveal homogenous morphology with a surface roughness of RMS $=33 \mathrm{~nm}$ for the $\mathrm{FAPbI}_{3}$ sample. The film RMS value slightly increases when increasing the GA content with a maximum value of $47.73 \mathrm{~nm}$ at a $10 \%$ GA sample. AFM investigation approves the SEM analysis, which indicates the formation of aggregate crystals with different sizes, suggesting the difficulty to incorporate GA up of $20 \%$ [30, 31, 32].

Figure 7.5 indicates the details of optical properties and the impact of GA concentration on the $\mathrm{FAPbI}_{3}$ thin films. The slight onset dispersion of the absorption edge value $1.8 \mathrm{eV}$ consistent with the reported value for $\mathrm{FAPbI}_{3}[33]$.

a)

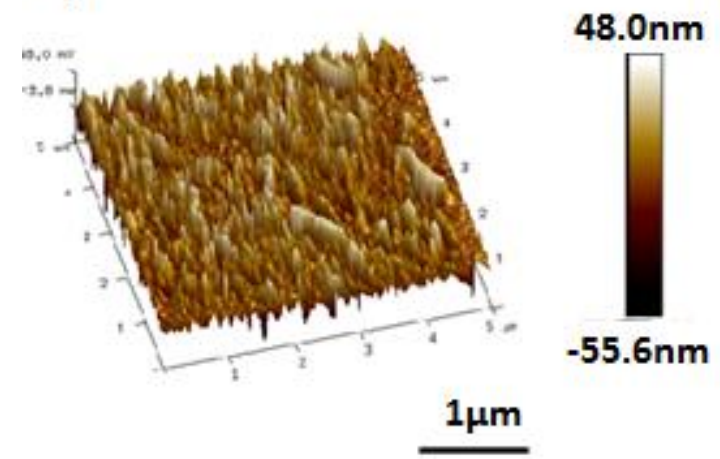

c)

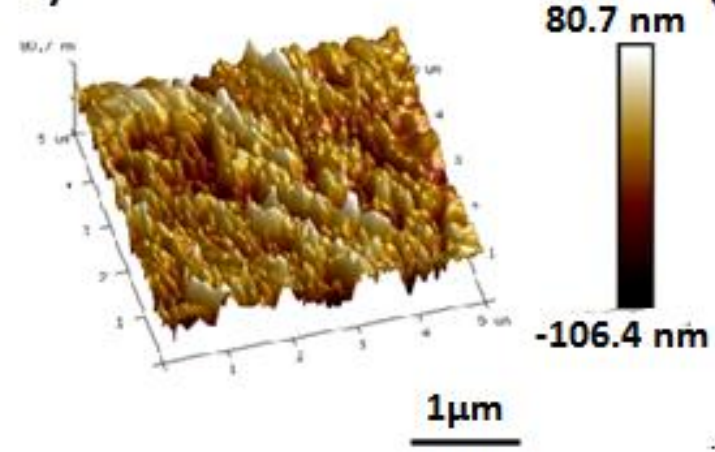

b)

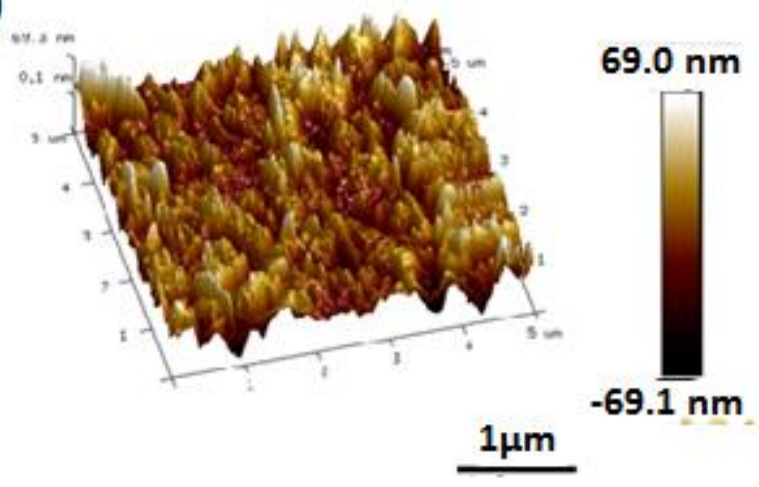

d)

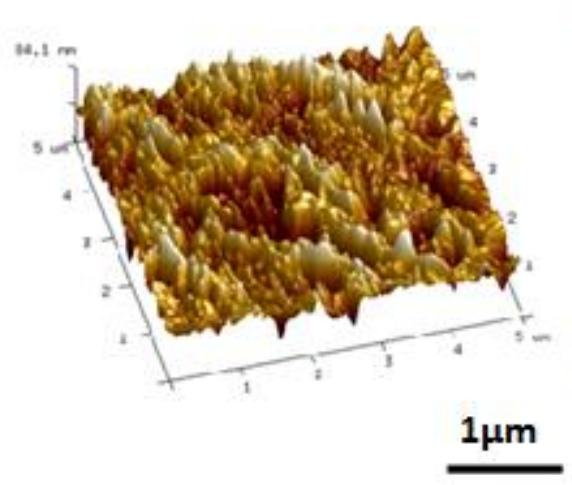

$84.1 \mathrm{~nm}$

$-107.0 \mathrm{~nm}$

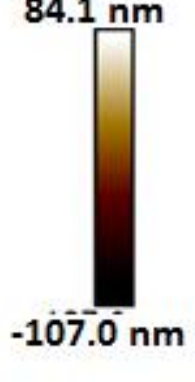

$1 \mu \mathrm{m}$

Figure 7.4. AFM Images of perovskite films $\mathrm{FA}_{1-\mathrm{x}} \mathrm{GA}_{x} \mathrm{PbI}_{3}$ (a) $2.5 \%$ (b) $5 \%$ (c) $10 \%$ and (d) 20 $\%$ of GA.

\subsection{Optical analysis of FAPbI3 doped GA Perovskite Thin Films}

The absorption spectra of $\mathrm{FaPbI}_{3}$ with various GA amount $(0 \%, 2.5 \%, 5 \%, 10 \%$ and $20 \%)$ is present in figure 5 (a). it's observed that the addition of GA content covers the diffused transmittance and reflection of $\mathrm{FaPbI}_{3}$. Moreover, significant increases were found in the absorption edge to high 
energy wavelength. These results are in good agreement of the crystallite improvement which is discussed previously XRD experiment. The estimated optical bandgap calculated by Tauc plots displays in figure 7.5 (b). The bandgap energies were noticed to decreases to lower energy with the addition of GA from 0 to $10 \%$. Herein, the incorporation of $20 \%$ GA content demonstrated the confirmation of the previously proposed lattice parameters change.

Table 7.2 summarized the optical bandgap (Eg) values of $\mathrm{FA}_{1-\mathrm{x}} \mathrm{GA}_{\mathrm{x}} \mathrm{PbI}_{3}$, extracted from $\mathrm{UV}$ and PL measurements. The absorption edge slightly decreases from 1.75 to $1.41 \mathrm{eV}$ when the GA content was increased. The PL emission global difference between the $\mathrm{FaPbI}_{3}$ and $\mathrm{FA}_{1-\mathrm{x}} \mathrm{GA}_{\mathrm{x}} \mathrm{PbI}_{3}$ samples is being $1.8-1.45 \mathrm{eV}$.
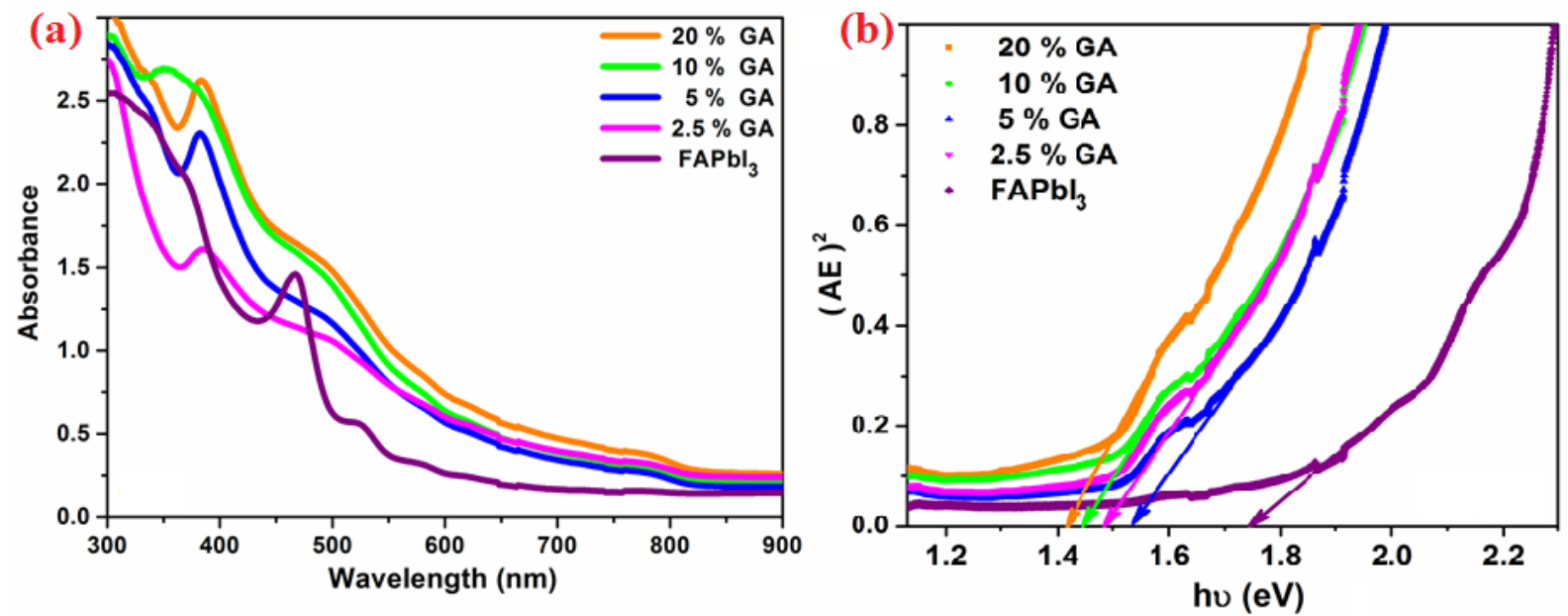

Figure 7.5. (a) UV-Vis absorption spectra of $\mathrm{FA}_{1-\mathrm{x}} \mathrm{GA}_{\mathrm{x}} \mathrm{PbI}_{3}(\mathrm{x}=0,2.5,5,10$ and $20 \%)$ (b) Variations in the optical bandgap for $\mathrm{x} \% \mathrm{GA}: \mathrm{FAPbI}_{3}$.

The PL intensity of the $\mathrm{FAPbI}_{3}$ films can be boosted by $\sim 4$ times by changing the environment from vacuum to air. The enhanced PL emission in air can be attributed to the reduced density of trap states, originated from by the GA vacancies in the $\mathrm{FAPbI}_{3}$ lattice. Reducing surface trap states decreases the charge recombination and consequently leads to an increase in the photoelectric efficiency.

Figure $7.6(\mathrm{a}, \mathrm{b})$ show the growth of emission spectra corresponding to $\mathrm{FAPbI}_{3}$ varying $\mathrm{GA}$ content $(0 \%, 2.5 \%, 5 \%, 10 \%$ and $20 \%)$. From The normalized PL spectra, a significant shift was observed to the lower wavelength. This lower wavelength shift indicates the formation of FA/GA in the perovskite lattice. The enhanced PL emission can be attributed to the reduced density of surface trap states due to the decreases in the quantity of non-radiative paths and at that point, the 
recombination happens over the radiative stage. The transition from $\mathrm{FAPbI}_{3}$ to doped $\mathrm{FA}_{1-\mathrm{x}} \mathrm{GA}_{\mathrm{x}} \mathrm{PbI}_{3}$ observed in the PL spectra which is in good agreement with the XRD results and optical absorbance spectra. Besides, Table 7.2 summarized the obtained results from PL and UV-Vis spectra of $\mathrm{FAPbI}_{3}$ and different GA content.
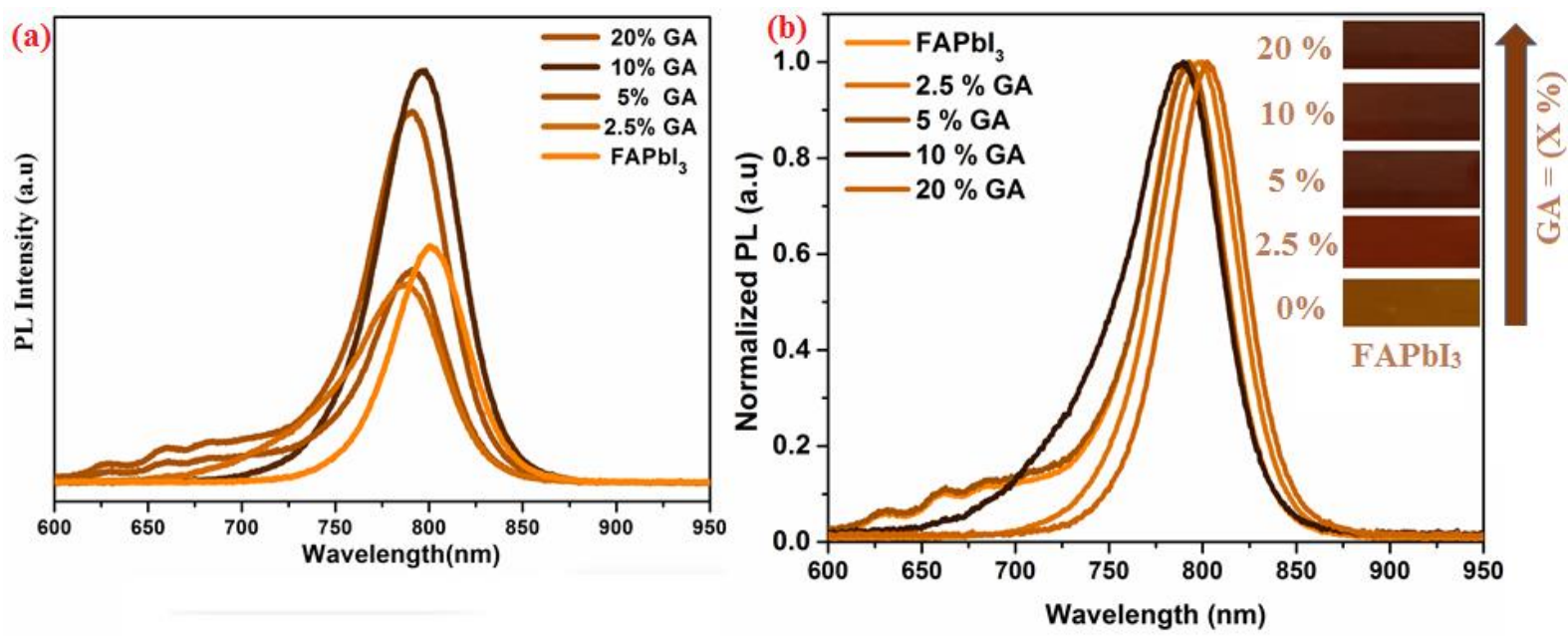

Figure 7.6. (a) $\mathrm{PL}$ of $\mathrm{FAPbI}_{3}$ doped GA (b) Normalized PL along with thin films images.

Table 7.2. Band gap variation according to GA content

\begin{tabular}{|c|c|c|c|}
\hline \multirow{2}{*}{ Sample.ID } & PL & Absorption & Stokes shift \\
\cline { 2 - 4 } & $\mathbf{E}(\mathbf{e V})$ & $\mathbf{E}(\mathbf{e V})$ & eV \\
\hline $\mathbf{0 \%}$ GA & 1.8 & 1.75 & 0.05 \\
\hline $\mathbf{2 . 5 \%}$ GA & 1.57 & 1.55 & 0.02 \\
\hline $\mathbf{5 \%}$ GA & 1.59 & 1.50 & 0.09 \\
\hline $\mathbf{1 0 \%}$ GA & 1.5 & 1.42 & 0.08 \\
\hline $\mathbf{2 0 \%}$ GA & 1.45 & 1.41 & 0.04 \\
\hline
\end{tabular}

As it can be observed in Table 7.2, that the gap energy for $10 \% \mathrm{GA}: \mathrm{FAPbI}_{3}$ is lower than the band gap for $\mathrm{FAPbI}_{3}$, which could be like result of substitution with $\mathrm{GA}$, and, then creating additional energy stages between the valence band and conduction band, and as a consequence decreasing of the gap.

\section{Degradation mechanism of $\mathrm{FAPbI}_{3}$ and $\mathrm{GA}$ doped $\mathrm{FAPbI}_{3}$ Perovskite Thin Films}


The degradation mechanism of XRD patterns were examined for $\mathrm{FAPbI}_{3}$ and $10 \% \mathrm{GA}$ : $\mathrm{FAPbI}_{3}$ fresh and aged samples in figure 7.7 (a) and (c), respectively. In humid environment the $\mathrm{FAPbI}_{3}$ films degraded within two week and appear the undesirable $\delta-\mathrm{FAPbI}_{3}$ phase in the films. This is confirmed by the enhancement of the peak located at $12.6^{\circ}$ and associated with the $\delta$ phase. In contrast, the sample with $10 \%$ GA show no additional peaks or enhancement of $\delta$ phase peak intensity. Thus, the existence of GA atoms is efficient to control the co-existence of two perovskite phases in humid conditions and prevent any dissociation of $\mathrm{FAPbI}_{3}$ into $\mathrm{PbI}_{2}$. $\mathrm{XRD}$ results agree with PL measurements which show a major decrease in PL intensity, around double intensity of the pure $\mathrm{FAPbI}_{3}$ samples, after two weeks in humid conditions, indicating the degradation of $\mathrm{FAPbI}_{3}$. The PL spectrum of $\mathrm{FA}_{0.9} \mathrm{GA}_{0.1} \mathrm{PbI}_{3}$ film show a slight intensity decrease indicating a slow degradation when $10 \%$ GA is present figure 7.7 ( $b$ and d). Hence, our results suggest that the incorporation of a small amount of GA can enhance the stability of the black phase perovskite structure of $\mathrm{FAPbI}_{3}$ [35].
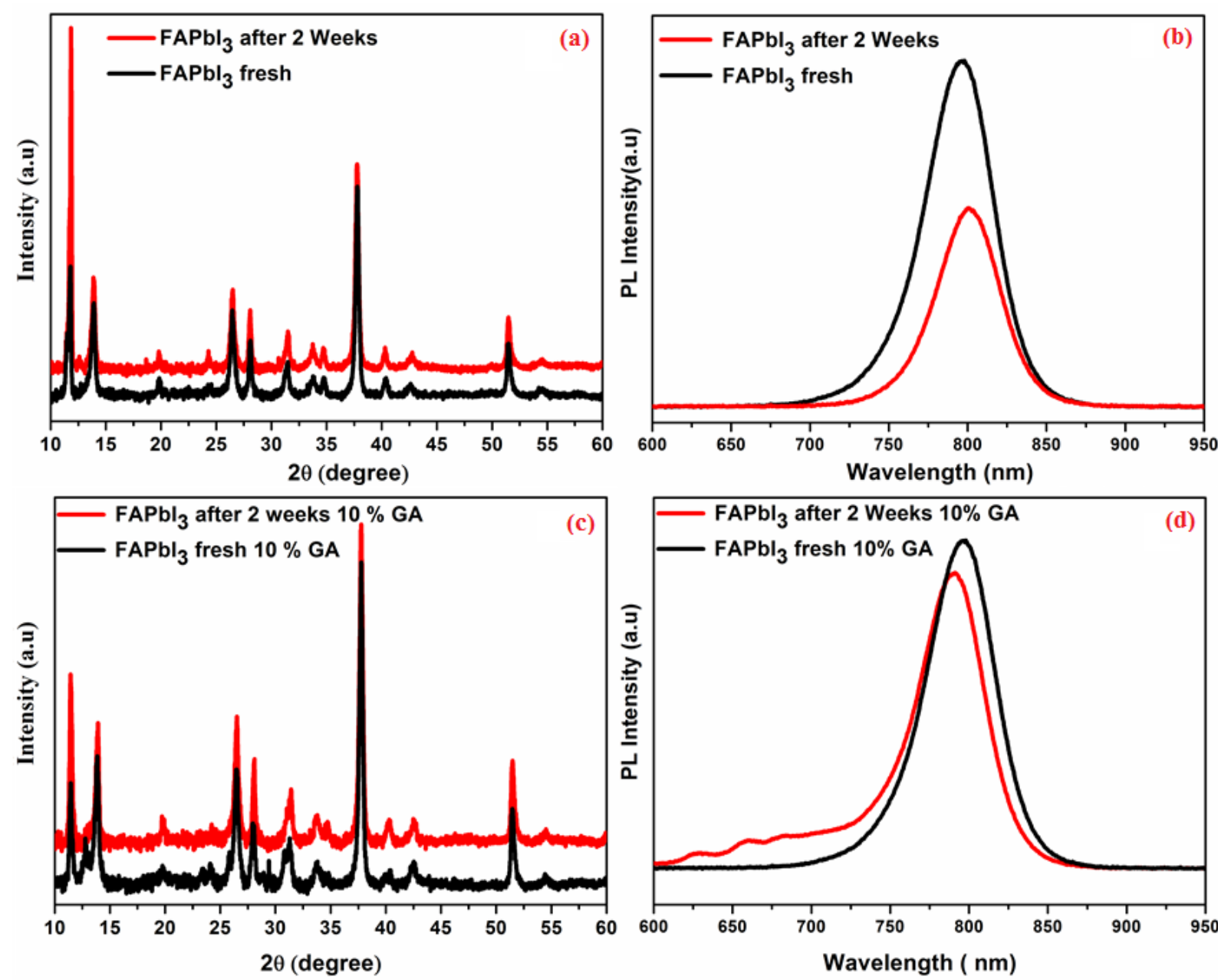
Figure 7.7. (a, b) XRD and PL of $\mathrm{FAPbI}_{3}$ before and after 2 weeks (c, d) XRD and PL of $\mathrm{FA}_{0.9} \mathrm{GA}_{0.1} \mathrm{PbI}_{3}$ before and after 2 weeks.

Figure 7.8 displays SEM images that show apparition of several pinhole and change in surface morphology for pure $\mathrm{FAPbI}_{3}-\mathrm{Aged}$ as we can note that for with incorporate $10 \% \mathrm{GA}$ the surface shows fewer pinholes after two weeks in humid environments which it's in agreement with results of XRD and PL that confirm the stability of $10 \%$ GA sample, Here we can show a route to enhance the stability of $\mathrm{FAPbI}_{3}$. It's confirmed from the results that the incorporation of GA contents stabilizes the black phase of $\mathrm{FAPbI}_{3}$ with improved the XRD by suppressed the $\delta$ phase transition. Furthermore, PL and optical properties showing a good agreement to enhance the performance and stability of the films.
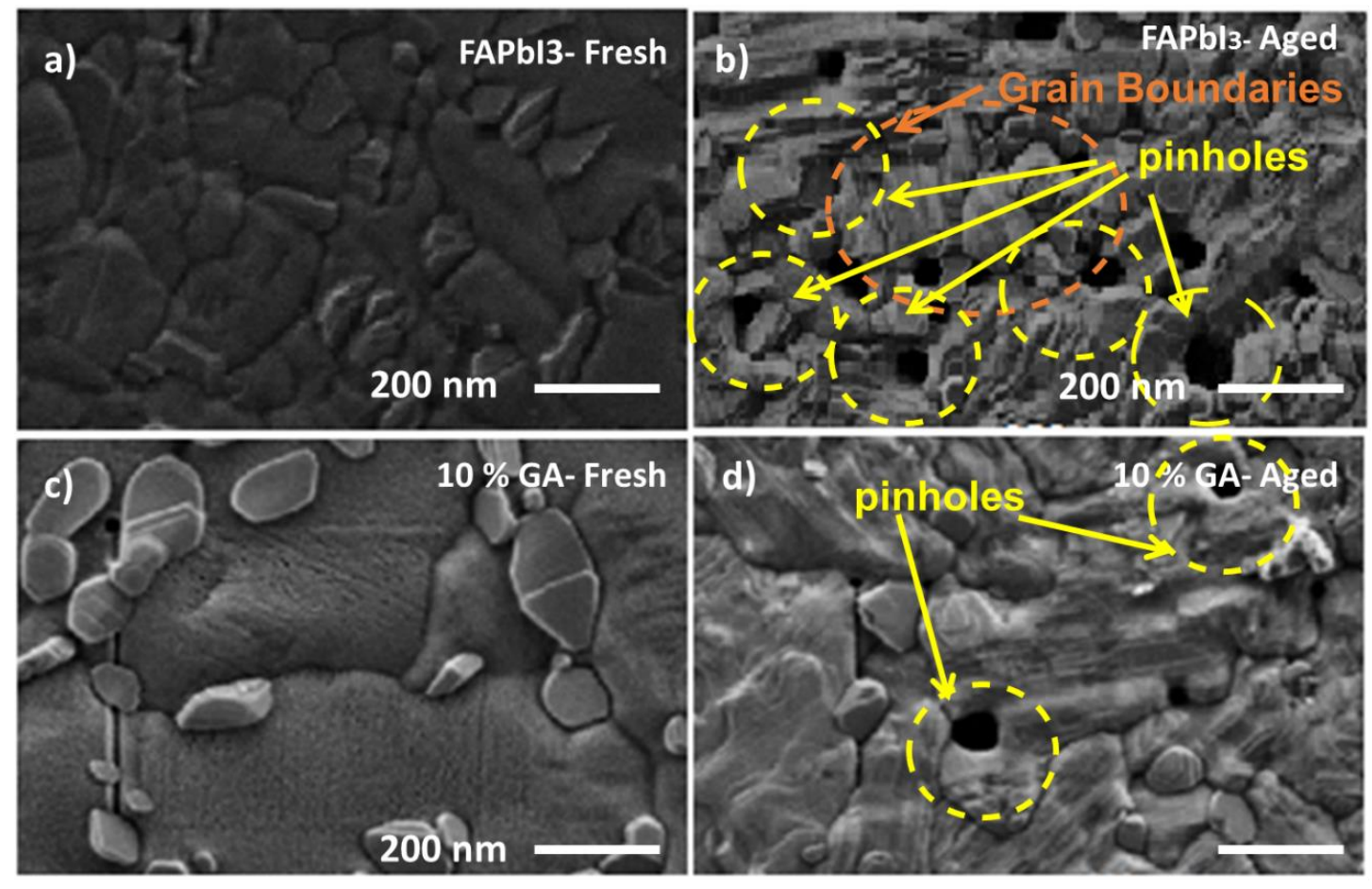

Figure 7.8. $\mathrm{FESEM}$ of $\mathrm{FAPbI}_{3}$ and $\mathrm{FA}_{0.9} \mathrm{GA}_{0.1} \mathrm{PbI}_{3}$ before and after 2 weeks.

The GA $10 \%$ shows an important role to slow down the degradation of $\mathrm{FAPbI}_{3}$ thin films which illustrate in figure 7.9. Therefore, the study of UV-Vis spectroscopy could significantly improve the stability of perovskite thin films. This evolution is correlated with a color change of the color of the film for dark brown to orange-brown after two weeks as shown in photographs. 


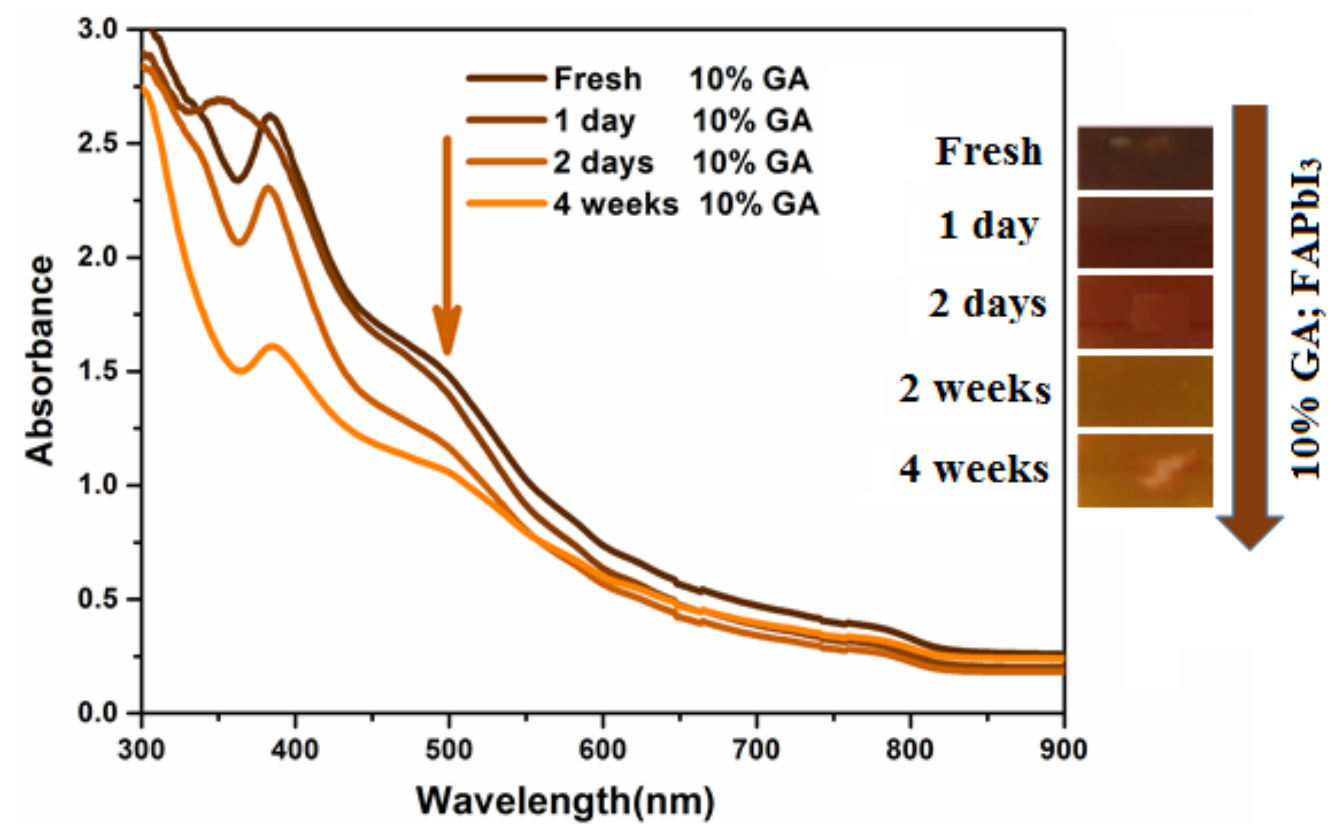

Figure 7.9. Absorbance spectra and photograph of $\mathrm{FA}_{0.9} \mathrm{GA}_{0.1} \mathrm{PbI}_{3}$ fresh and aged of 1 day, 2 days and 2 Weeks at $60 \% \mathrm{RH}$.

In this work, we have investigated the effect of GA incorporation into $\mathrm{FAPbI}_{3}$ lattice on the control of the $\alpha / \delta$ phases. Our results show that a small amount of $10 \%$ GA, can hugely improve the morphology of the $\mathrm{FAPbI}_{3}$ film and slow down the degradation rate in humid areas. GA: films exhibit smooth and homogeneous surface coverage with clear boundaries and no pinholes. XRD results indicated that the presence of GA enhances the growth of the $\alpha$ cubic black phase. The presence of GA has shown to slow down the degradation rate by preventing the formation of the $\delta-\mathrm{FAPbI}_{3}$ phase and $\mathrm{PbI}_{2}$ compounds. These results contribute to the fundamental understanding of the degradation mechanism of $\mathrm{FAPbI}_{3}$ offering strategies for designing stable and high-performance $\mathrm{FAPbI}_{3}$ based devices. 


\section{References:}

[1] Köhnen, E., Jošt, M., Morales-Vilches, A. B., Tockhorn, P., Al-Ashouri, A., Macco, B., \& Stannowski, B. (2019). Highly efficient monolithic perovskite silicon tandem solar cells: analyzing the influence of current mismatch on device performance. Sustainable Energy \& Fuels.

[2] Nazarenko, O., Yakunin, S., Morad, V., Cherniukh, I., \& Kovalenko, M. V. (2017). Single crystals of caesium formamidinium lead halide perovskites: solution growth and gamma dosimetry. NPG Asia Materials, 9(4), e373.

[3] Hu, M., Liu, L., Mei, A., Yang, Y., Liu, T., \& Han, H. (2014). Efficient hole-conductor-free, fully printable mesoscopic perovskite solar cells with a broad light harvester $\mathrm{NH} 2 \mathrm{CH}$ [double bond, length as m-dash] NH 2 PbI 3. Journal of Materials Chemistry A, 2(40), 17115-17121.

[4] Yang, W. S., Park, B. W., Jung, E. H., Jeon, N. J., Kim, Y. C., Lee, D. U., ... \& Seok, S. I. (2017). Iodide management in formamidinium-lead-halide-based perovskite layers for efficient solar cells. Science, 356(6345), 1376-1379.

[5] Ono, L. K., Leyden, M. R., Wang, S., \& Qi, Y. (2016). Organometal halide perovskite thin films and solar cells by vapor deposition. Journal of Materials Chemistry A, 4(18), 6693-6713.

[6] Mali, S. S., Shim, C. S., \& Hong, C. K. (2015). Highly stable and efficient solid-state solar cells based on methylammonium lead bromide $(\mathrm{CH} 3 \mathrm{NH} 3 \mathrm{PbBr} 3)$ perovskite quantum dots. NPG Asia Materials, 7(8), e208.

[7] Palma, A. L., Matteocci, F., Vesce, L., Castriotta, L. A., \& Yaghoobi, N. Perovskite solar modules: a path to record-breaking devices.

[8] Li, C., Lu, X., Ding, W., Feng, L., Gao, Y., \& Guo, Z. (2008). Formability of ABX3 (X= F, Cl, Br, I) Halide Perovskites. Acta Crystallographica Section B: Structural Science, 64(6), 702-707.

[9] Eperon, G. E., Stranks, S. D., Menelaou, C., Johnston, M. B., Herz, L. M., \& Snaith, H. J. (2014). Formamidinium lead trihalide: a broadly tunable perovskite for efficient planar heterojunction solar cells. Energy \& Environmental Science, 7(3), 982-988.

[10] Yang, W. S., Noh, J. H., Jeon, N. J., Kim, Y. C., Ryu, S., Seo, J., \& Seok, S. I. (2015). Highperformance photovoltaic perovskite layers fabricated through intramolecular exchange. Science, 348(6240), 1234-1237.

[11] Guo, Y., Li, C., Li, X., Niu, Y., Hou, S., \& Wang, F. (2017). Effects of Rb Incorporation and Water Degradation on the Stability of the Cubic Formamidinium Lead Iodide Perovskite Surface: A First-Principles Study. The Journal of Physical Chemistry C, 121(23), 12711-12717.

[12] Liang, F. X., Wang, J. Z., Zhang, Z. X., Wang, Y. Y., Gao, Y., \& Luo, L. B. (2017). Broadband, ultrafast, self-driven photodetector based on Cs-doped FAPbI3 perovskite thin film. Advanced Optical Materials, 5(22), 1700654.

[13] Syzgantseva, O. A., Saliba, M., Grätzel, M., \& Rothlisberger, U. (2017). Stabilization of the perovskite phase of formamidinium lead triiodide by methylammonium, Cs, and/or Rb doping. The journal of physical chemistry letters, 8(6), 1191-1196. 
[14] Lee, J. W., Kim, D. H., Kim, H. S., Seo, S. W., Cho, S. M., \& Park, N. G. (2015). Formamidinium and cesium hybridization for photo-and moisture-stable perovskite solar cell. Advanced Energy Materials, 5(20), 1501310.

[15] Yi, C., Luo, J., Meloni, S., Boziki, A., Ashari-Astani, N., Grätzel, C., \& Grätzel, M. (2016). Entropic stabilization of mixed A-cation ABX 3 metal halide perovskites for high performance perovskite solar cells. Energy \& Environmental Science, 9(2), 656-662.

[16] Pool, V. L., Dou, B., Van Campen, D. G., Klein-Stockert, T. R., Barnes, F. S., Shaheen, S. E., ... \& Toney, M. F. (2017). Thermal engineering of FAPbI 3 perovskite material via radiative thermal annealing and in situ XRD. Nature communications, 8, 14075.

[17] Koh, T. M., Fu, K., Fang, Y., Chen, S., Sum, T. C., Mathews, N. \& Baikie, T. (2013). Formamidinium-containing metal-halide: an alternative material for near-IR absorption perovskite solar cells. The Journal of Physical Chemistry C, 118(30), 16458-16462.

[18] Ono, L. K., Leyden, M. R., Wang, S., \& Qi, Y. (2016). Organometal halide perovskite thin films and solar cells by vapor deposition. Journal of Materials Chemistry A, 4(18), 6693-6713.

[19] Leyden, M. R., Jiang, Y., \& Qi, Y. (2016). Chemical vapor deposition grown formamidinium perovskite solar modules with high steady state power and thermal stability. Journal of Materials Chemistry A, 4(34), 13125-13132.

[20] Ávila, J., Momblona, C., Boix, P. P., Sessolo, M., \& Bolink, H. J. (2017). Vapor-deposited perovskites: the route to high-performance solar cell production?. Joule, 1(3), 431-442.

[21] Mali, S. S., Shim, C. S., \& Hong, C. K. (2015). Highly stable and efficient solid-state solar cells based on methylammonium lead bromide $(\mathrm{CH} 3 \mathrm{NH} 3 \mathrm{PbBr} 3)$ perovskite quantum dots. NPG Asia Materials, 7(8), e208.

[22] Palma, A. L., Matteocci, F., Vesce, L., Castriotta, L. A., \& Yaghoobi, N. Perovskite solar modules: a path to record-breaking devices.

[23] Pool, V. L., Dou, B., Van Campen, D. G., Klein-Stockert, T. R., Barnes, F. S., Shaheen, S. E., ... \& Toney, M. F. (2017). Thermal engineering of FAPbI 3 perovskite material via radiative thermal annealing and in situ XRD. Nature communications, 8, 14075.

[24] Aharon, S., Dymshits, A., Rotem, A., \& Etgar, L. (2015). Temperature dependence of hole conductor free formamidinium lead iodide perovskite based solar cells. Journal of Materials Chemistry A, 3(17), 9171-9178.

[25] Lv, S., Pang, S., Zhou, Y., Padture, N. P., Hu, H., Wang, L. \& Cui, G. (2014). One-step, solutionprocessed formamidinium lead trihalide (FAPbI $(3-\mathrm{x}) \mathrm{Cl}$ x) for mesoscopic perovskite-polymer solar cells. Physical Chemistry Chemical Physics, 16(36), 19206-19211.

[26] Zhang, Y., Zhou, Z., Ji, F., Li, Z., Cui, G., Gao, P. \& Pang, S. (2018). Trash into treasure: $\delta$ FAPbI3 polymorph stabilized MAPbI3 perovskite with power conversion efficiency beyond 21\%. Advanced Materials, 30(22), 1707143. 
[27] Hu, Y., Qiu, T., Bai, F., Miao, X., \& Zhang, S. (2017). Enhancing moisture-tolerance and photovoltaic performances of FAPbI3 by bismuth incorporation. Journal of Materials Chemistry A, 5(48), 25258-25265.

[28] Koh, T. M., Fu, K., Fang, Y., Chen, S., Sum, T. C., Mathews, N. \& Baikie, T. (2013). Formamidinium-containing metal-halide: an alternative material for near-IR absorption perovskite solar cells. The Journal of Physical Chemistry C, 118(30), 16458-16462.

[29] Gu, L., Zhang, D., Kam, M., Zhang, Q., Poddar, S., Fu, Y. \& Fan, Z. (2018). Significantly improved black phase stability of FAPbI 3 nanowires via spatially confined vapor phase growth in nanoporous templates. Nanoscale, 10(32), 15164-15172.

[30] Liang, F. X., Wang, J. Z., Zhang, Z. X., Wang, Y. Y., Gao, Y., \& Luo, L. B. (2017). Broadband, ultrafast, self-driven photodetector based on Cs-doped FAPbI3 perovskite thin film. Advanced Optical Materials, 5(22), 1700654.

[31] Zhou, N., Shen, Y., Zhang, Y., Xu, Z., Zheng, G., Li, L. \& Zhou, H. (2017). CsI Pre-Intercalation in the Inorganic Framework for Efficient and Stable FA1- x CsxPbI3 (Cl) Perovskite Solar Cells. Small, 13(23), 1700484.

[32] Li, W., Yadavalli, S. K., Lizarazo-Ferro, D., Chen, M., Zhou, Y., Padture, N. P., \& Zia, R. (2018). Subgrain special boundaries in halide perovskite thin films restrict carrier diffusion. ACS Energy Letters, 3(11), 2669-2670.

[33] Lv, S., Pang, S., Zhou, Y., Padture, N. P., Hu, H., Wang, L., ... \& Cui, G. (2014). One-step, solution-processed formamidinium lead trihalide (FAPbI $(3-\mathrm{x}) \mathrm{Cl} \mathrm{x}$ ) for mesoscopic perovskitepolymer solar cells. Physical Chemistry Chemical Physics, 16(36), 19206-19211.

[34] Zheng, H., \& Dai, J. (2017). Temperature-dependent photoluminescence properties of [HC (NH2) 2] PbI3 perovskite nanorods. Materials Letters, 188, 232-234.

[35] Smecca, E., Numata, Y., Deretzis, I., Pellegrino, G., Boninelli, S., Miyasaka, T. \& Alberti, A. (2016). Stability of solution-processed MAPbI 3 and FAPbI 3 layers. Physical Chemistry Chemical Physics, 18(19), 13413-13422. 


\section{Chapter VIII: Work outlook: Tandem Perovskite/CIGS}

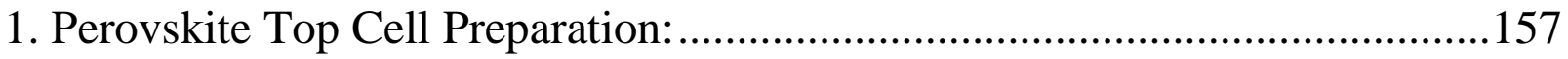

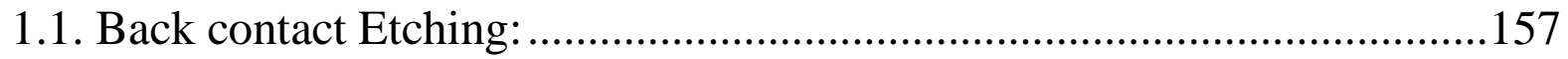

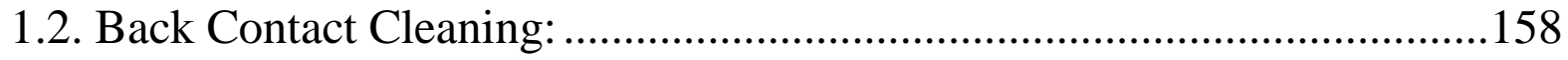

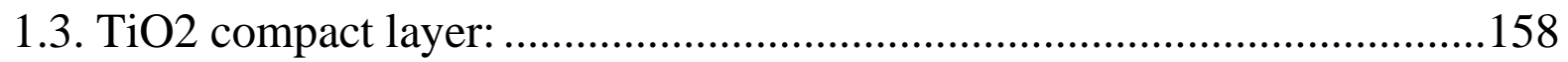

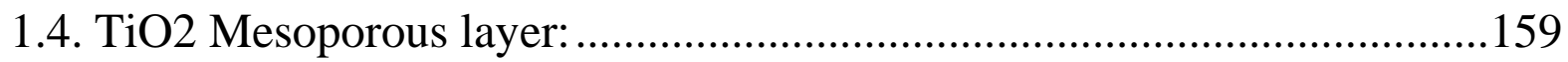

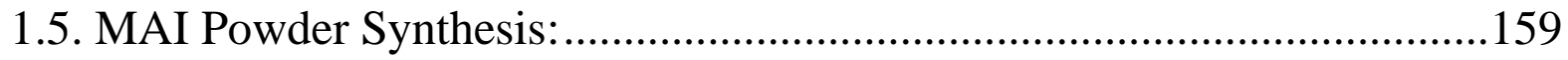

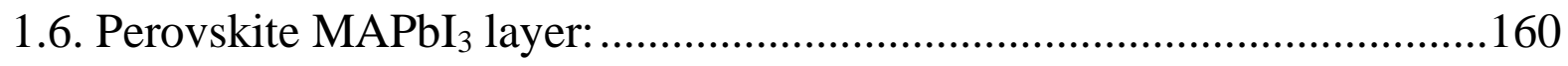

1.7. Spiro-MeOTAD layer:........................................................................ 160

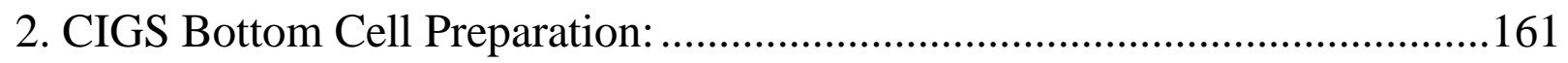

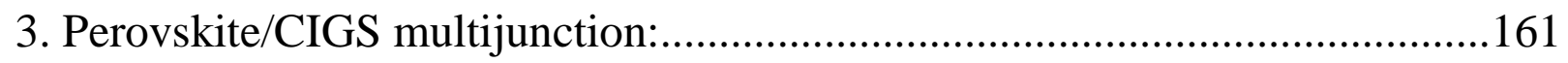


The cell is called "tandem" for the reason that stacking two layers - perovskite and CIGS - which make it possible to exploit a larger part of the light spectrum: the first absorbs wavelengths in the visible, the second in the infrared. tandem presents a new generation of powerful solar cells in terms of efficiency. Our future work will be to combines two types of solar cells CIGS and Perovskites in our case MAPbI3.

\section{Perovskite Top Cell Preparation:}

Perovskite top cells were fabricated on fluorine-doped tin oxide (FTO)-coated glass substrates. First the Compact $\mathrm{TiO}_{2}$ layer was elaborated via spray pyrolysis technique followed by the deposition of a mesoporous $\mathrm{TiO}_{2}$ layer by spin coating technique. The perovskite $\mathrm{MAPbI}_{3}$ layer was deposited by spin coating and the film was annealed at $100{ }^{\circ} \mathrm{C}$. then the spiro-OMeTAD was deposited by spin coating technique.

\subsection{Back contact Etching:}

The FTO is etched away from one edge of the substrate with $\mathrm{Zn}$ powder and concentrated $\mathrm{HCl}(32 \%)$ as shown in figure 8.1. The area not to etch is protected with Kapton tape. An uncovered stripe about 5-6 mm large is etched. Zn powder is distributed on the uncoated area with a spatula, then $\mathrm{HCl}$ is dropped on it. The reaction produces $\mathrm{ZnCl}_{2}$ and $\mathrm{H}_{2}$, the latter reduces the FTO, which can be removed by using a Q-tip. Finally, the substrate is rinsed in water and dried. One can normally see by bare eye whether the etching was successful or not. 


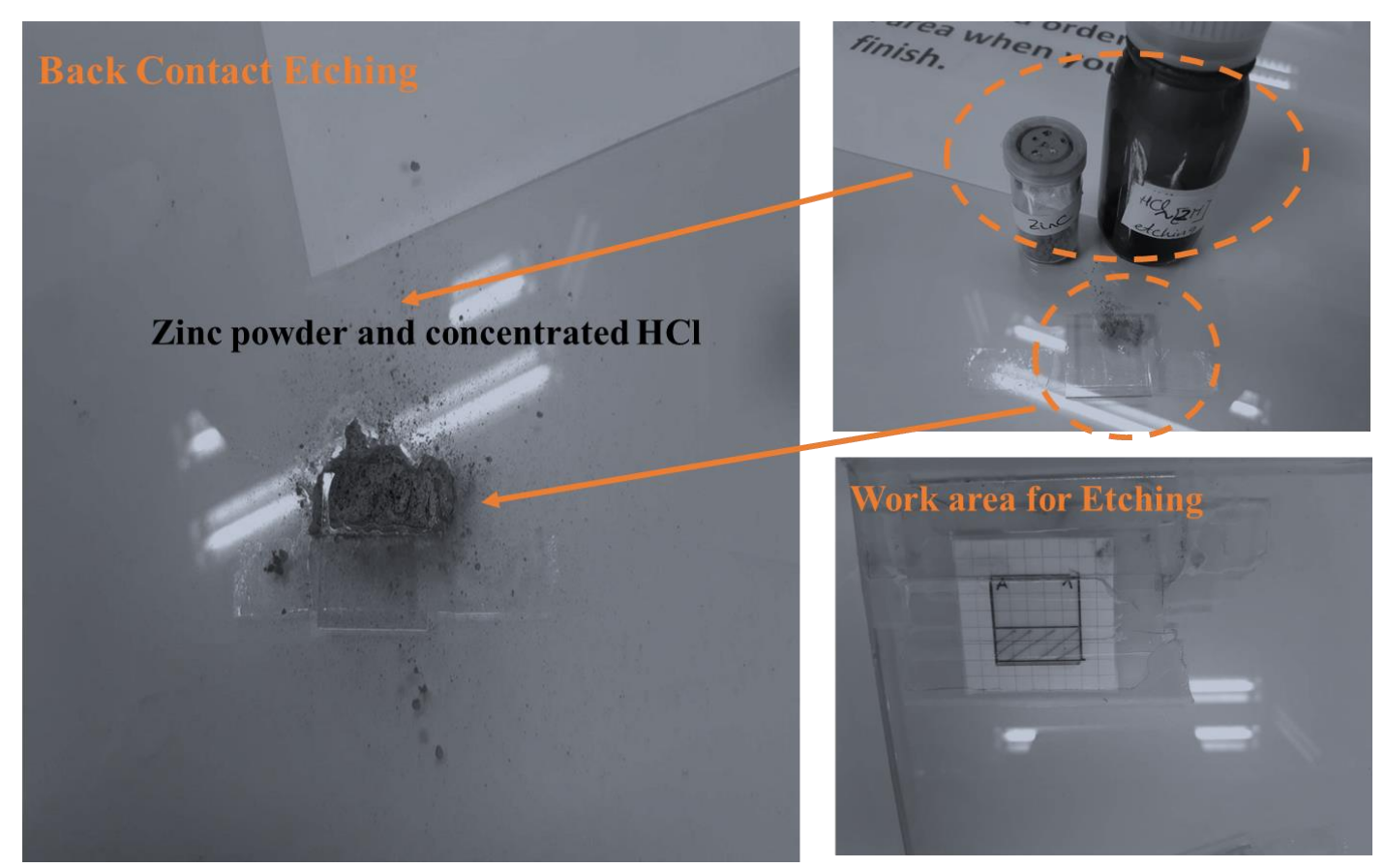

Figure 8.1: process for etching the back contact FTO

\subsection{Back Contact Cleaning:}

First the tape is removed from the FTO glass, then it's cleaned in ultrasound bath with Hellmanex $2 \%$ for $15 \mathrm{~min}$ after we watched with distilled water and we put again in ultrasound bath with acetone for 15 min after in ethanol for 15min.in last stage we treat the FTO glass by UV-ozone treatment for 15 minutes to improve the wetting of water-based solutions and could be beneficial for the continuity of the blocking layer.

\section{3. $\mathrm{TiO}_{2}$ compact layer:}

The $\mathrm{TiO} 2$ blocking layer is spin-coated after masking the edges with Kapton tape to avoid the presence of $\mathrm{TiO} 2$ at the electrical contacts. Tape must be about $5 \mathrm{~mm}$ large on each side. (figure 8.2) 


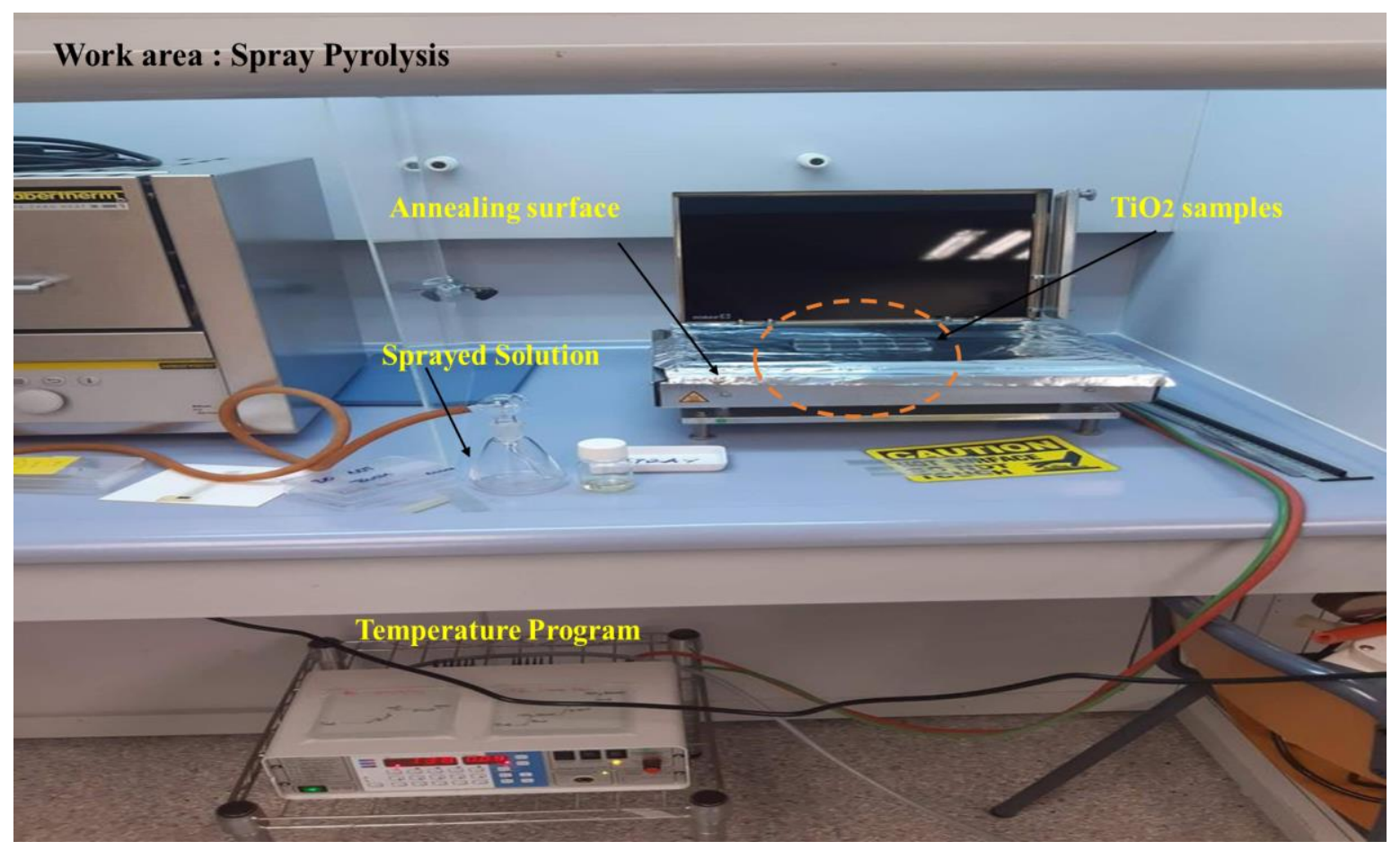

Figure 8.2: $\mathrm{TiO}_{2}$ compact layer prepared by spray pyrolysis

\section{4. $\mathrm{TiO}_{2}$ Mesoporous layer:}

paste of $20 \mathrm{~nm} \mathrm{TiO}_{2}$ nanoparticles diluted in ethanol and stirred for several hours before using. Spincoat at $5000 \mathrm{rpm}, 30 \mathrm{~s}$ as shown in figure 8.3. Drying $140{ }^{\circ} \mathrm{C}, 5$ minutes. Gradual heating to $380{ }^{\circ} \mathrm{C}$, stay 30 minutes, then to $500{ }^{\circ} \mathrm{C}$, stay 30 minutes. Let cool down slowly to $200{ }^{\circ} \mathrm{C}$ before opening the oven. Burn the $\mathrm{TiO}_{2}$ films at $500{ }^{\circ} \mathrm{C}$ prior to use to remove water. 

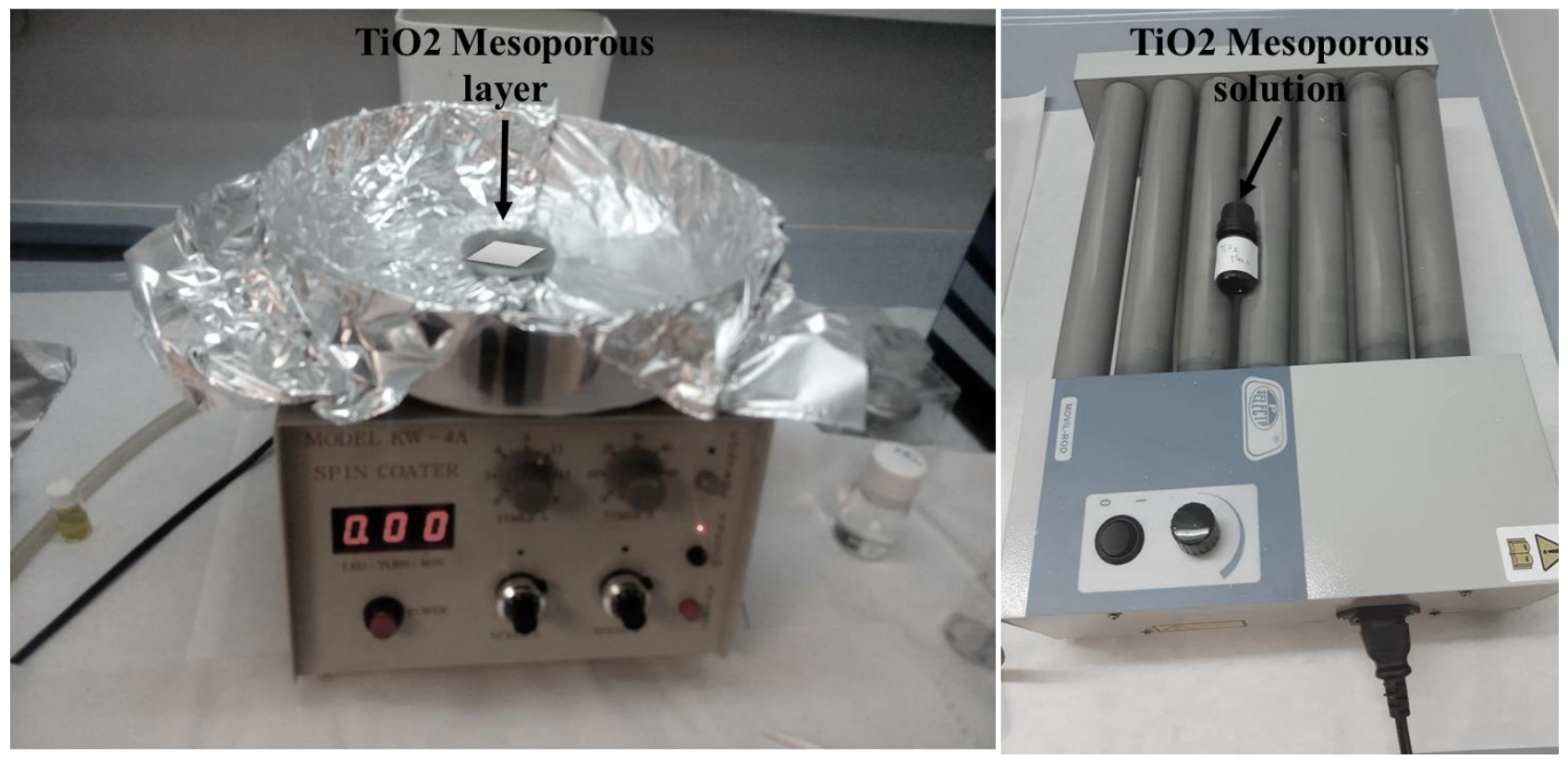

Figure 8.3 TiO2 compact layer prepared by spray pyrolysis

\subsection{MAI Powder Synthesis:}

MAI or $\mathrm{CH}_{3} \mathrm{NH}_{3} \mathrm{I}$ was synthesized by reacting $30 \mathrm{~mL}$ of methylamine (40\% in methanol, TCI) and $32.3 \mathrm{~mL}$ of hydroiodic acid (57 wt\% in water, Aldrich) in a $250 \mathrm{~mL}$ round-bottom flask at $0{ }^{\circ} \mathrm{C}$ for $2 \mathrm{~h}$ with stirring. The precipitate was recovered by putting the solution on a rotary evaporator and carefully removing the solvents at $50{ }^{\circ} \mathrm{C}$. The yellowish raw product methylammonium iodide $\left(\mathrm{CH}_{3} \mathrm{NH} 3 \mathrm{I}\right)$ was washed with diethyl ether by stirring the solution for $30 \mathrm{~min}$, a step which was repeated three times, and then finally recrystallized from a mixed solvent of diethyl ether and ethanol. After filtration, the solid was collected and dried at $60{ }^{\circ} \mathrm{C}$ in a vacuum oven for $24 \mathrm{~h}$.

\subsection{Perovskite $\mathrm{MAPbI}_{3}$ layer:}

In $1 \mathrm{ml}$ of DMSO, dissolve $0.669 \mathrm{~g}$ of $\mathrm{PbI}_{2}$ and $0.231 \mathrm{~g}$ of MAI, then the solution is spin coated at $1000 \mathrm{rpm}$ for $10 \mathrm{sec}$ and at $5000 \mathrm{rpm}$ for $30 \mathrm{sec}$. During the last 10 seconds of spin-coating an antisolvent was added (CB). The perovskite films were annealed at $100^{\circ} \mathrm{C}$ for $1 \mathrm{~min}$. 


\subsection{Spiro-OmeTAD layer:}

Prepare a solution of $72.3 \mathrm{mg}$ Spiro-OmeTAD in $1 \mathrm{~mL}$ of chlorobenzene.

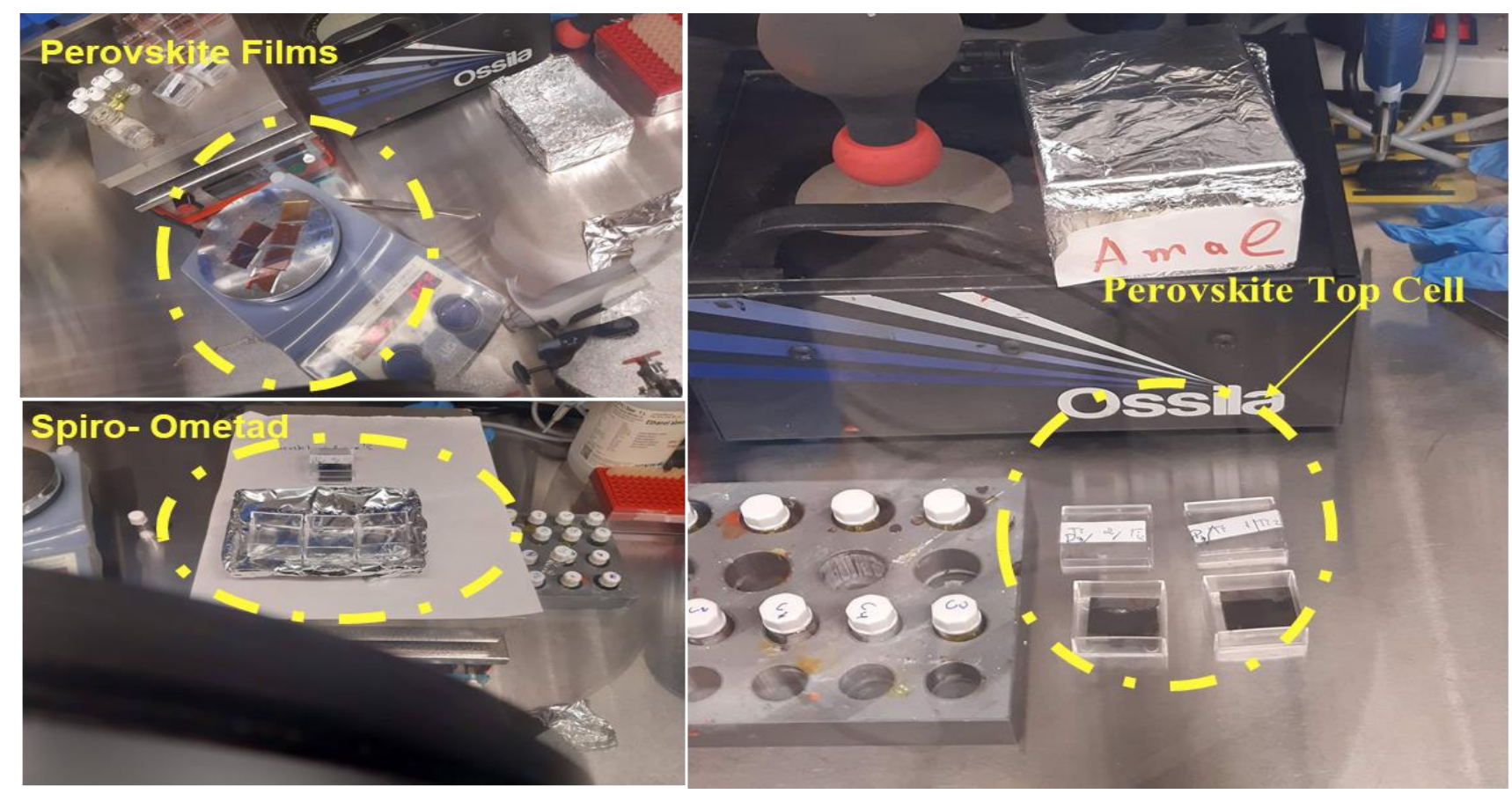

Figure 8.4: Spiro Ometad/MaPbI $3 / \mathrm{TiO}_{2} / \mathrm{FTO}$ Top Cell Preparation 


\section{CIGS Bottom Cell Preparation:}

CIGS solar cells were prepared using a process similar to the one previously indicated in chapter $\mathrm{V}$. Here, the solar cells were grown on glass substrate with a $\mathrm{SiO}_{2}$ layer as diffusion barrier for alkaline elements. Molybdenum as electrical back contact. CIGS was grown using electrodeposition. The $\mathrm{CdS}$ layer was grown using chemical bath deposition. $\mathrm{i}-\mathrm{ZnO}$ and $\mathrm{ZnO}: \mathrm{Al}$ layers were deposited by rf-sputtering and a metallic grid was deposited by electron beam evaporation.

\section{Perovskite/CIGS multijunction:}

Both perovskite and CIGS are thin film technologies, and can be fabricated on flexible substrates in a cost-effective manner. In addition, the bandgaps of perovskite and CIGS in combination would result in widened absorption of the solar spectrum. Therefore, integrated photovoltaics and mobile devices using perovskite and CIGS have enormous potential.in figure 8.4 displays the layers constitute the tandem perovskite/CIGS and their thickness.
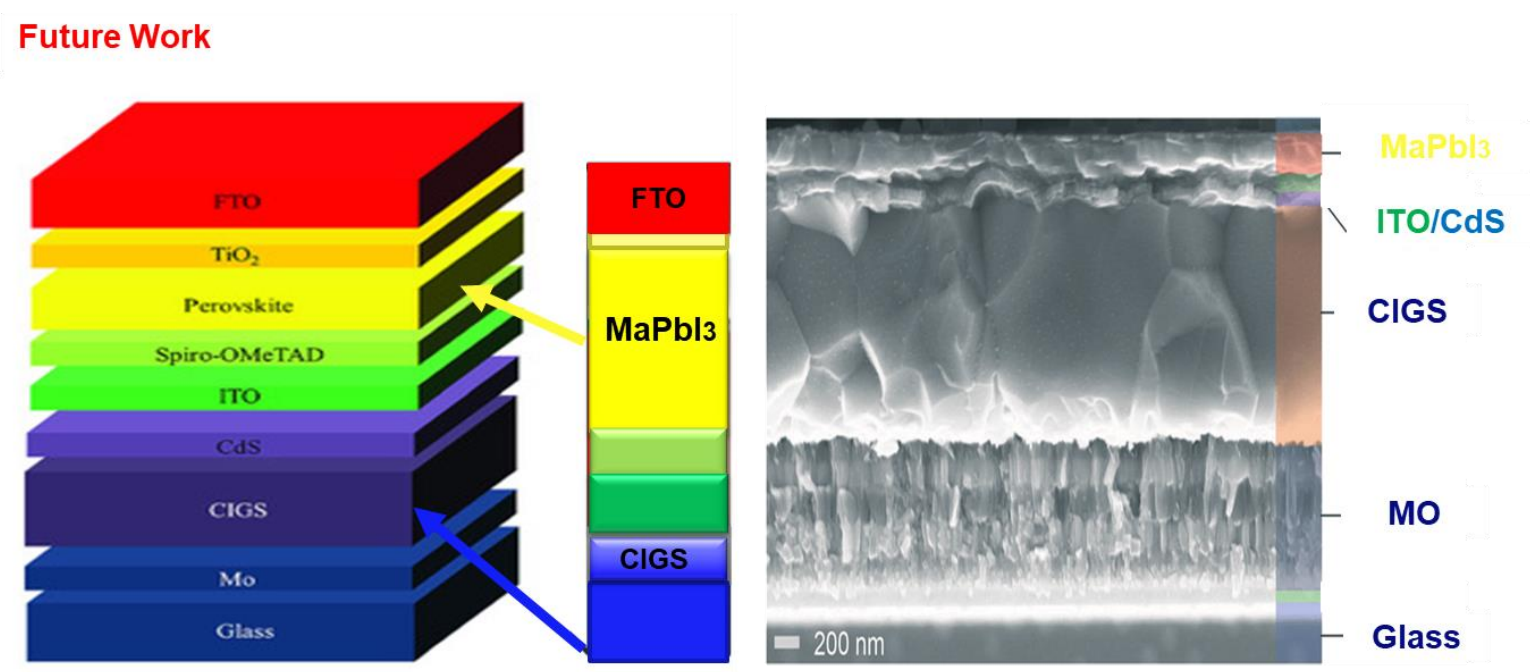

Figure 8.5: SEM image of Tandem Perovskite/CIGS

In future work we will work to optimize the structure of solar cell and to avoid all the problem of diffusion between the layers we will try to improve the efficiency of heterojunction solar cells. 


\section{Publications in journals}

[1] Bouich, A., Ullah, S., Marí, B., Atourki, L., \& Touhami, M. E. (2020). One-step synthesis of FA1-xGAxPbI3 perovskites thin film with enhanced stability of alpha $(\alpha)$ phase. Materials Chemistry and Physics, 123973.

[2] Bouich, A., Ullah, S., Ullah, H., Mollar, M., Marí, B., \& Touhami, M. E. (2020). Electrodeposited CdZnS/CdS/CIGS/Mo: Characterization and Solar Cell Performance. JOM, 72(2), 615-620.

[3] Bouich, A., Ullah, S., Ullah, H., Mari, B., Hartiti, B., Touhami, M. E., \& Santos, D. M. F. (2019). Deposit on different back contacts: to high-quality CuInGaS 2 thin films for photovoltaic application. Journal of Materials Science: Materials in Electronics, 30(23), 20832-20839.

[4] Bouich, A., Hartiti, B., Ullah, S., Ullah, H., Touhami, M. E., Santos, D. M. F., \& Mari, B. (2019). Optoelectronic characterization of CuInGa (S) 2 thin films grown by spray pyrolysis for photovoltaic application. Applied Physics A, 125(8), 579.

[5] Bouich, A., Hartiti, B., Ullah, S., Ullah, H., Touhami, M. E., Santos, D. M. F., \& Mari, B. (2019). Experimental, theoretical, and numerical simulation of the performance of CuInxGa (1x) S2-based solar cells. Optik, 183, 137-147.

[6] Bouich, A., Hartiti, B., Ullah, S., Touhami, M. E., Mari, B., \& Santos, D. M. F. (2019). Investigation of the optical properties of CuIn (Se, S) 2 thin films for photovoltaic application. Materials Today: Proceedings, 13, 663-669.

[7] Bouich, A., Ullah, S., Ullah, H., Mari, B., Touhami, M. E., Hartiti, B., \& MF, S. D. (2018, December). Optoelectronic Characterization of CuIn (S, Se) 2 Thin Grown by Spray Pyrolysis Method for Solar Cells. In 2018 6th International Renewable and Sustainable Energy Conference (IRSEC) (pp. 1-5). IEEE.

[8] Bouich, A., Marí, B., Atourki, L., Ullah, S., \& Touhami, M. E. Shedding Light on the Effect of Diethyl Ether Antisolvent on the Growth of (CH3NH3) PbI3 Thin Films. JOM, 10.1007/s11837-020-04518-5

[9] Ullah, S., Bouich, A., Ullah, H., Mari, B., \& Mollar, M. (2020). Comparative study of binary cadmium sulfide (CdS) and tin disulfide (SnS2) thin buffer layers. Solar Energy, 208, 637-642. [10] Ullah, S., Bouich, A., Ullah, H., Mari, B., \& Mollar, M. (2020). Enhanced optical and structural properties of V-doped binary SnS2 buffer layer. Solar Energy, 204, 654-659. 
[11] Ullah, S., Bouich, A., Ullah, H., Fleitas, E. V., Baig, F., Hameed, Y., \& Marí, B. (2019). Influence of Fe Content in Binary SnS2 Synthesis by Hydrothermal Technique for Photovoltaic Application. ECS Journal of Solid State Science and Technology, 8(6), Q118.

[12] Ullah, S., Bouich, A., Mollar, M., Marí, B., Ullah, H., \& Ullah, R. (2018, December). Synthesis of Ternary CuGaSe 2 and CuGaS 2 Electrochemical Deposition for Photovoltaic Application. In 2018 6th International Renewable and Sustainable Energy Conference (IRSEC) (pp. 1-4). IEEE.

[13] Ullah, S., Bouich, A., Baig, F., Khattak, Y., Mollar, M., Mari, B., \& Ullah, H. (2018, September). Hydrothermal Synthesis of SnS 2 and Sn 1-x Fe x S 2 Powders. In 2018 International Conference on Power Generation Systems and Renewable Energy Technologies (PGSRET) (pp. 1-5). IEEE.

[14] Coulibaly, AB, Bouich,A, Shafi ullah ,Aka,B ,Mari,B. Experimental and Numerical study of (CH3NH3PbI3) MaPbI3 thin film with fluorene- dithiophene (FDT) or spiroometad as hole transporter layer, IOSR Journal Of Applied Physics (IOSR-JAP) e-ISSN: 2278-4861.Volume 12, Issue 2 Ser. II (Mar.- Apr. 2020), PP 17-26 www.Iosrjournals.Org

[15] Bouich, A., Ullah, S., Marí, B, \& Touhami, M. E. Enhanced stability of Methylammonium lead triiodide MAPbI3 Perovskites Thin films doping by Tetrabutylammonium (TBA) under consideration in Applied Surface Science journal

\section{Oral Presentation:}

- Oral communication: Ternary $\mathrm{CuGaSe} 2$ and $\mathrm{CuGaS} 2$ thin films prepared by electrochemical deposition for photovoltaic application, PGSRET 2018, Shafi Ullah, Hanif Ullah, Amal Bouich, Rahat Ullah, Miguel Mollar and Bernabe Mari.

- Oral communication: Shafi Ullah; Amal Bouich; Miguel Mollar; Bernabé Marí; Hanif Ullah; Rahat Ullah, Synthesis of Ternary CuGaSe2 and CuGaS2 Electrochemical Deposition for Photovoltaic Application, Conference Paper,2018 6th International Renewable and Sustainable Energy Conference (IRSEC).

-Oral communication: Amal Bouich; Shafi Ullah; Hanif Ullah; Bernabé Mari; Mohamed Ebn Touhami; Bouchaib Hartiti and Santo. DMS. Optoelectronic Characterization of CuIn(S,Se)2 Thin Grown by Spray Pyrolysis Method for Solar Cells, Conference Paper,2018 6th International Renewable and Sustainable Energy Conference (IRSEC).

- Oral communication: Amal Bouich, Shafi Ullah, Hanif Ullah, Miguel Mollar, Bernabé Marí, Mohamed Ebn Touhami; "ID- 225 Electrodeposited CdZnS/CdS/CIGS/Mo: Characterization 
and solar cells performance" paper accepted by the conference committee of the 7. European Conference on Renewable Energy Systems. 10-12 JUNE 2019- MADRID/SPAIN

- Presented poster title: characterization of copper indium gallium thin layers prepared by electroplating international conference on advances in energy technologies environment engineering and materials science (AETEEMS), 10-11th, 2017, Mohammedia, Morocco. A. Bouich, B. Hartiti, M. Ebn Touhami. D.M.F. Santos

- Presented poster title: characterization of CIS and CIGS-based thin layers prepared by electroplating, international conference Encontro de Ciência e tecnologia, "3-5th,2017, Centro de congresses de Lisbon, Portugal. A. Bouich, B. Hartiti, M. Ebn Touhami, D.M.F. Santos

- Presented poster title: elaboration et characterization of thin film cis et cigs by electrodeposition technique, international meeting "nano and smart materials for renewable energy"28, 29th April 2016 Casablanca-Morocco. A. Bouich, B. Hartiti, M. Ebn Touhami , D.M.F. Santos

- Presented poster title: Investigation of the optical properties of $\mathrm{CuInSe}_{2}$ and $\mathrm{CuInS}_{2}$ thin films for photovoltaic application, CIMFAT 2017 A. Bouich, B. Hartiti, M. Ebn Touhami, D.M.F. Santos

- Oral presentation: Investigation of the optical properties of $\mathrm{CuIn}(\mathrm{Se}, \mathrm{S}) 2$ thin films for photovoltaic application, 2nd International Conference on Materials and Environmental Science ICMES 2018, 26-28 avril 2018 Saidia-Morocco A. Bouich, B. Hartiti, M. Ebn Touhami, D.M.F. Santos

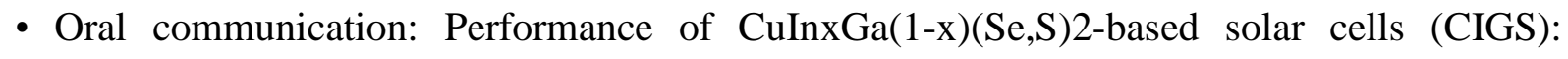
Analysis by numerical simulations via SCAPS simulator, Amal. Bouich, Bouchaib. Hartiti, Mohamed. Ebn Touhami, Diogo.M.F. Santos, 2nd International Material Sciences and Engineering for Green Energy Conference, IMSEGC2018 


\section{Prizes and achievements}

- Attendance with oral presentation selected (Pitch Challenge) of VI Meeting of PhD Students at Polytechnic University Valencia UPV. This activity, part of the doctoral transversal training program of activities, has among its objectives to publicize the contents of the thesis in development, the exchange of information and knowledge among the $\mathrm{PhD}$ candidates and highlight the value of the degree of Doctor to access to the labor market. Meeting of PhD Students Edition 2019

- Award the following four mobility grants for students of the Polytechnic University of Valencia within the University Junior International Entrepreneurs 5U CV 2019 program

- XIV Ideas UPV Awards, Advanced Idea award by participating by the idea manufacture of tandem perovskites/CIGS solar cells, Edition 2020

- Finalist of Edition III of Award UPV 2019. 